\title{
Balázs Péter
}

Zsengék, töredékek, kétes hitelüek

(A Madách-Rimay-kódexek Szerelmes énekek c. füzetének versanyaga)

doktori értekezés

SZTE BTK

Irodalomtudományi Doktori Iskola

Témavezető: Dr. Szilasi László

Szeged, 2016 
„A szavak is dolgok. Csak épp a szavaktól melyeknek birtokába jut senki sem foszthatja meg. Sokkalta fontosabbak semmint azon körülmény hogy ö maga nem ismeri a jelentésüket."

Cormac McCarthy

„Rimay mindent tud, Rimay mindent megmond, forduljon Rimayhoz!”

Mándy Iván

„A grammatika feldöl, van min ellegóznia. / Az újraépülésekböl feláll egy allegória."

Závada Péter

„,Csak módjával azzal a hagyománnyal!’

Ludditák 


\section{Tartalom}

\section{[I.] BEVEZETÉS}

A tok és a látcső

A Madách-Rimay-kódexek Szerelmes énekek c. füzetéről készült fotokópia.

A szövegközlésröl

\section{[II.] TÜZETES RÉSZ}

1. Ne gondold, szerelmem, könnyü indulatnak................................ 21

2. Nagy példát adhatok énrólam mindennek....................................... 31

3. Ki-ki terhét vállán közülünk viseli ............................................... 40

4. Bírja bár akárki nagy jószágú Lévát ............................................. 47

5. Szerelemtül csak kár, hogy tiltunk szép személt .................................. 56

6. Semmi állat nincsen földön nyomorultabb....................................... 66

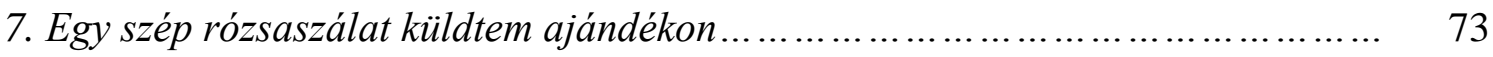

8. Látod ez gyöngyszemet ........................................................ 81

9. Oly nehéz nem látnom elöttem járnia ........................................... 91

10. Hárfa ...at valahova juthat, mindent csendesit ................................... 98

11. Ércnél, kösziklánál keménybnek vallhatnál....................................... 109

12. Szerelmesitől vált valóban nagy kínt lát ......................................... 119

13. Én édes jobb kezem, töled kedven veszem...................................... 129

14. Örüll, immár, lelkem, szép kincset találtál.................................... 139

15. Beborult, fölhözött, bánat hozó egem ............................................ 148

\section{[III.] KONKLÚZIÓ}

Jég, kása, hegy

[IV.] APPENDIX

A Rimay-örökség Madách Gáspár tollán. 
2. A versszerző Madách Gáspár 182

2.1. Madách mint moralizáló versek szerzője 182

2.2. Madách mint latrikánus versek szerzője 188

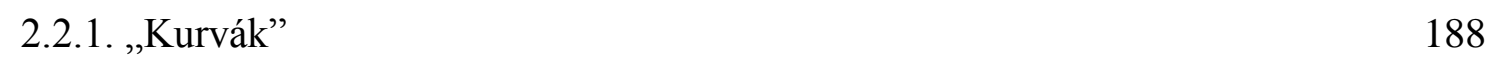

2.2.2. „Latrok” 191

$\begin{array}{ll}2.3 . \text { Konklúzió } & 193\end{array}$

Bibliográfia........................................................... 194 


\section{BEVEZETÉS}




\section{A tok és a látcső}

A jelenlegi alakjukban Madách-Rimay-kódexek néven ismert kolligátumok három kötete 1950 óta gazdagítja az Országos Széchényi Könyvtár állományát, az első kettő Rimay János hátrahagyott munkái 1. ill. 2., a harmadik, Sztregovai Madách Gáspár versei címen. ${ }^{1}$ A bennük foglalt korpusz Madách Gáspár költői, fordítói, szöveggondozói tevékenységének legjelentősebb dokumentuma. ${ }^{2}$ A kolligátumok jellege arról tanúskodik, hogy Madách alapvetően füzetekbe dolgozott, ámde ezek anyaga is meglehetősen heterogén; a szövegek sorrendjében átfogó poétikai koncepció nemigen érhető tetten.

A Madách Gáspár irodalmi hagyatékát képező iratkötegre Radvánszky Béla bukkant rá az 1890-es évek környékén. Ebbéli felfedezéséről kétszer is számot adott. Első ízben akkor, amikor az Irodalomtörténeti Közleményekben közzéteszi az addig ismeretlen költő verseit: „Évekkel ezelôtt sajó-kazai levéltáramhoz tartozó mindenféle írások között egy összekötött csomagra találtam, melyben nagy meglepetésemre Rimay János verseit, szerelmes énekeit és más munkáit fedeztem fel, mellé voltak téve Madách Gáspár itt közölt énekeinek eredeti kéziratai. "3 Majd az 1904-es Rimay-összkiadásának előszavában, ahol is a kettéosztott anyag másik felét szintúgy autográfként mutatja be: „Pár évvel ezután [ti. a Balassa-kódex felfedezése után] sajó-kazai levéltáram többfelé lévő részeit összeszedegetve, egy csomó haszontalanság között egy összekötött csomagot találtam, melyben nagy meglepetésemre Rimay János írásait és énekeinek eredeti kéziratát ismertem fel. "4

Azzal, hogy Radvánszky pontosan mit és hogyan ismert fel, először a Balassi Bálint összes műveinek kritikai kiadását előkészítő Eckhardt Sándor kénytelen szembesülni mintegy félszáz évvel később. Ö állapítja meg, hogy a kódexeket író kéz egyedül a Madách Gáspáré, és hogy az azokból Radvánszky által Rimaynak tulajdonított versek zöme is az övé lehet. Eckhardt azt hozza föl Radvánszky mentségére, hogy Madách kézírásának kétféle duktusa közül (ahogy azt Radvánszky meg is jegyzi ${ }^{5}$ ) az egyik valóban hasonlít a Rimayéhoz. Ugyanakkor felhívja a figyelmet az iratokon végigvonuló sajátságos ortográfia gyakorlatra,

\footnotetext{
${ }^{1}$ Quart. Hung. 3245/1-2 és 3246 jelzet alatt.

${ }^{2}$ A kötetektől független kisebb egységet képez a Sajó-kazai III. c. néven emlegetett ív és az ún. Treboszlóitöredék. (Vö. JANKOVICS József, ,Akadtam egy picturára.” Rimay János és Madách Gáspár allegorikus versének képzömüvészeti vonatkozásai, ItK, 1982, 652-656.; JENEI Ferenc, A Balassi-hagyaték történetéhez, ItK, 1966, 190-197.)

${ }^{3}$ RADVÁNSZKY Béla, Sztregovai Madách Gáspár versei, ItK, 1901, 130.

${ }^{4}$ RIMAY János Munkái, kiad. RADVÁNSZKY Béla, Bp., 1904, IV. A továbbiakban: RJM.

${ }^{5}$ Uo., VIII.
} 
valamint a törlésekre és javítgatásokra is, amelyek feltétlenül saját munkára engednek következtetni, és a jellegzetes értelmetlenségekre, amelyek pontatlanul másolt idegen anyagra - ezért az egész félreértést alapjában véve csodálatosnak tartja. ${ }^{6}$

Eckhardt arra is rávilágít, hogy a kódexek voltaképpen nem is kódexek, hanem formájukat a 19. század végén elnyert gyüjtemények. Ugyanis miután Radvánszky rátalált a füzetcsomókra, azokat legjobb tudása szerint az ezekből kivehető két szerzői név (Madách Gáspár és Rimay János) között osztotta el, ezután pedig mindegyiket felcímzett levélpárok közé fogta, paginálta és egymáshoz igazítva bőrbe köttette. ${ }^{7}$ Eckhardt szerint az elhibázott attribúciót éppen az eredményezte, hogy Radvánszky igyekezett biztosra menni: „Madách mindegyikhez valami megjegyzést írt hozzá, amiböl kiderül a szerzősége. Másoknál olyan kelet van megadva, ami kizárja Rimay szerzőségét. Ezért különitette el őket Radvánszky a többi füzetböl, nem ismerve fel az írás azonosságát. "8 Nos, Madách Gáspár írásképe valóban nem egységes, igazság szerint azonban Radvánszkyt nem az eltérő duktusok vezették félre, hanem maga a kötegelés.

A fentiek ismeretében szokás úgy gondolni, hogy a kötetek és azon belül a füzetek jelenlegi sorrendje is Radvánszky önkényének gyümölcse, sőt hogy egyes kallódó levelek utólagos beillesztése a füzetek egységébe szintén az ő számlájára írható. ${ }^{9}$ Ahhoz viszont, hogy a talált csomagból mindent felhasznált, nem férhet kétség; legalábbis erre utal az üzleti érdekü

\footnotetext{
${ }^{6}$ BALASsI Bálint Összes müvei, kiad. ECKHARDT Sándor, I, Bp., Akadémiai, 1951 [a továbbiakban: BÖM], 26; RIMAY János Összes müvei, kiad. ECKHARDT Sándor, Bp. Akadémiai, 1955 [a továbbiakban: RÖM], 163.

${ }^{7}$ A kolligátumok részletes bibliográfiai leírása Rimay és Madách müveinek kritikai kiadásában egyaránt megtalálható. (Vö. RÖM 163-165. ill. Régi Magyar Költök Tára, XVII. század, 12, Madách Gáspár, Egy névtelen, Beniczky Péter, Gróf Balassa Bálint, Listius László, Esterházy Pál és Fráter István versei, szerk. Stoll Béla, s. a. rend. VARGA Imre, Cs. HAVAs Ágnes, Stoll Béla, Bp., Akadémiai, 1987 [a továbbiakban: RMKT XVII/12.], 663-665.) Mindkét jegyzék helytálló; mindazonáltal egyik sem tartalmazza, milyen címeket adott Radvánszky Béla az egyes köteteknek ill. füzeteknek. Ehelyütt viszont az áttekinthetőség miatt mégiscsak szükségesnek vélem közölni azokat.

Rimay János hátrahagyott munkái, 1. kötet. 1. Balassa-testvérek dicsérete. 2. Szerelmes énekek. 3. Encomia et effecta virtutum. 4. Az keresztyén religio ábrázatja-Leges mensales J. R. 5. Cato disztichonai. 6. Rimay János által versei elébe írott 15. argumentum. 7. Rimay János ajánlólevele Darholcz Kristófhoz.

Rimay János hátrahagyott munkái, 2. kötet. 1. Cato alapján írott parafrázisok és másféle versek. 2. Rimay János bevezetése Balassa Bálint verseihez. 3. Memoriale az 1627. évi szönyi tárgyalásokról, irta Rimay János. 4. Orvosság ... az dögös pestishalálban, írta Rimay János. 5. Nagypénteki meditáció, írta Rimay János. 6. A parázna életröl, irta Rimay János.

Sztregovai Madách Gáspár versei. I. Rimay János latin verse, magyarra forditotta Madách Gáspár. II. Rimay János latin verse, magyar fordítás fogalmazata Madách Gáspártól. III. Igen szép énekek, cseh nyelvböl magyarra forditotta Madách Gáspár. IV. Calabria tartományra bocsátott Isten ostora 1638-ban csehböl magyarra fordittatott Madách Gáspár által. V. Krónika versekben, irta Madách Gáspár. VI. Wesselényi Ferenc nevére szerzett versek.

${ }^{8}$ RÖM, 165.

${ }^{9}$ Vö. ,,ezért különitette el őket Radvánszky a többi füzettöl” (RÖM, 165.); ,,[Radvánszky] elkülönített 8 kisebb terjedelmü füzetkét.” (RMKT XVII/12, 664.) „A Rimay - Madách-k. II. kötete 1. füzetébe [...] Radvánszky beragasztott egy levelet." (VARGA Imre, Tallózások Madách Gáspár körül, ItK, 1968, 68.)
} 
feljegyzések és az üres levelek kötésbe válogatása. ${ }^{10}$ A Madáchénak mondott harmadik kötet füzetei azonban nemcsak vékonyabbak, de kisebb alakúak is az első kettőéinél, továbbá azok közül nem egy se szignálva, se datálva nincsen. ${ }^{11}$ Ami azt jelenti, hogy Radvánszky (aki minden esetben az egyes füzetek anyagát tulajdonította en bloc a nevezett költők egyikének v. másikának) ${ }^{12}$ alighanem jóhiszeműen járt el. Iratokat kötegelni ti. méret alapján szokás. Ha ő valóban két paksamétát talált, és ezek közül az egyikben (a nagyobban) szerzőként csak Rimay János volt nevesítve, a másikban (a kisebben) csak Madách Gáspár, akkor a túlságosan kreatív szöveggondozói gyakorlat helyett éppenséggel egy túlságosan naiv megközelítés rajzolódik ki. ${ }^{13}$ Ennek belátásával viszont akár még azt is feltételezhetjük, hogy az egyes befüzetett lapokat is arra a helyre füz(et)te be, ahol megtalálta őket.

A fentiek ismeretében magától értetődik, hogy Radvánszky nagyjából-egészében ugyanazokat a negatívumokat kénytelen megállapítani mind Rimay, mint Madách poétai képességeit illetően. Rimay „nem igen ügyel a szépen folyó kifejezésekre. Költői nyelve és verselése darabos, olyan mintha alig forditott volna gondot reá, rímeire se mindig ügyel, néha igen szerencsétlenül választja meg azokat." 14 Madách „,nyelve gyakran darabos, sok helyt döczögösek a sorok és gyarlók a rímek, de egészben véve a költői tehetség nem tagadható meg

\footnotetext{
${ }^{10}$ Vö. Madách-Rimay-kódexek, III, Sztregovai Madách Gáspár Versei, 2r-3v ill. 53r-54v.

${ }^{11}$ A Radvánszky által Madáchnak tulajdonított tizenkét szövegböl csak a Rimay elveszett latin versének, a Soliloquiumnak fogalmazata és tisztázata, valamint a csehből fordított, versföiben Czobor Anna nevét hordozó négy ének szignált (RMKT XVII/12, 1-6. sz.). A bizonytalan szerzöségủ Az Úristenben bizzál... kezdetü ének, valamint a valószínüleg az 1577-ben Semptén kinyomtatott Vigasztaló könyvecske toldalékából származó Hatvan lelki örzö vitézek c. próza (7-8. sz.) azonban csak azon a jogon került a tizenkettő közé, hogy a csehböl fordított versekkel egy füzetben találhatóak, azok mögött foglalnak helyet. Az 1638-as Calabriai földrengésről szerzett versezet (9. sz.) értelemszerüen nem lehet a Rimayé. A Krónika címü (10. sz.), ill. ennek appendixe, a Hideg országnak mondják... incipitü (11. sz.) azonban elvileg sem explicit, sem implicit támpontot nem rejt a szerzőségre ill. a keletkezés idejére nézve. Az utolsó, a Hadadi Wesselényi Ferenc nevére szerzett, Balassistrófákból építkező darab (12. sz.) megírását pedig (báró) Radvánszky azért teszi 1646 utánra, mert annak argumentumában Wesselényi ,tekintetes és nagyságos”-ként van említve, márpedig ha Wesselényi 1646 áprilisában lett gróf - így Radvánszky -, e megszólítás tehát csak ez után dukált volna neki. Amit szerinte az is alátámaszt, hogy „,nehezebb, öregebb kéz irta e fohászkodást.” (RADVÁNSZKY, 1901, 131.) A paleográfiai rutintalanságot tekintve impozáns magabiztossággal tett megállapítás helytállósága azért is erösen kétséges, mert 1946-ban Madách Gáspár legkevesebb három éve halott volt. (Vö. RMKT XVII/12, 668.)

${ }^{12}$ Egy kivétellel: az I. kötet V. füzetében olvasható $A z$ hit remélendö dolgoknak állatja... kezdetủ vers argumentumában (84.) Radvánszky felismeri Madách Gáspár kézírását. Vö. RJM, 133.

${ }^{13}$ Ezt támasztja alá az is, hogy az egyetlen Madách-verset, amely szignált és datált is, de amely szerzőségét csupán egy személyrag árulja el (Dicséret, 8 die marty szereztem anno 1629), ugyanakkor egy nagyobb alakú füzetben található, Radvánszky a Rimay munkái közé sorolja.

${ }^{14}$ RADVÁNSZKY Béla, Rimay János szerelmes versei, BpSzle, 1904, 380. Az elhibázott szövegkritikai eljárás nyomán kialakított, szükségszerüen téves értékítéletnek az Eckhardt-féle Rimay-kiadás megjelenéséig gyakorolt negatív hatását Pirnát Antal is szóvá teszi a Spenót vonatkozó fejezetében. Vö. A magyar irodalom története 1600-tól 1772-ig, szerk. KlANICZAY Tibor, Bp., Akadémiai, 1964, 29. (Rimay János manierista stíluseszközei.)
} 
tőle. "15 Tegyük hozzá: Madách Gáspár szignált versei (ez persze aligha lehet véletlen) a jobban kimunkált írásai közé tartoznak.

Ezekből azonban egyáltalán nem következik az a Radvánszky által ugyanebben a dolgozatban is képviselt kategorikus értékítélet, melynek értelmében „,[k]étségtelen, hogy a költészetben Madách Rimay tanitványa, de valamint hogy Rimay János nem érte el nagy mesterét, Balassa Bálintot, úgy Madách sem mérközhetik mesterével."16 A jelenségre magyarázatként egyebek mellett az kínálkozik, hogy e vélemény kialakítása jószerével újfent nem eredeti elgondolásokon alapszik, hanem a Balassa-kódexet összeállító „müvelt, irodalomkedvelö férfiú" ${ }^{\prime 17}$ közléseire hagyatkozva jön létre - melynek hátterében viszont Rimay János szellemi hatása sejlik fel.

A Balassa-kódex három egységének (Balassi, Rimay és az ún. mostani poéták müvei) elrendezésében a vezérfonalat nyilvánvalóan az időrendiség képezi. Ez azonban más természetü megfontolásokkal is kiegészül. A Rimay-blokkot bevezető paratextus szerint ugyanis „,méltó, hogy a Balassi írásátúl messze ne hagyjuk, mert Balassi Bálinton kívöl csak egy magyar sem érkezhetik el víle, bár ugyan igyekezik is rajta. Kiröl etéletet tehet, akárki az irását olvassa, azmint Balassi Bálint is így szólott felöle éltiben (mond), ha úgy mégy elö dolgodban, azmint elkeztíl, gyakorolván azt, nem hogy el nem érkezvén víle, de meg is fogsz haladni. Söt halála óráján is ötet vallotta Balassi helyében valónak lenni..." "18 A rákövetkező elegyes tartalom élén ezzel azonos kritikai szempontrendszer alapján formált észrevétel olvasható: „Kezdenek itt már különb-különbféle szép énekek, melyeket ez mostani poéták szerzettek, akarván az poétaságban elméjeket fárasztván futtatni az Balassi Bálint elméjével és poétaságban elérni és meg is haladni, melynek bizony csak az egyike is kétség, nemhogy mindkettö. "19

Az elsőre idézett szöveghely több olyan információt is tartalmaz - különös tekintettel a Balassi Bálint halálos ágyánál elhangzottakra - melyek jobban meggondolva nemigen származhatnak mástól, mint magától Rimay Jánostól. Csakhogy (ahogyan azt Szilasi László is kiemeli a Balassi költői nyelvének 17. századi utóéletét vizsgáló monográfiájában ${ }^{20}$ ) tervezett Balassi-kiadásának előszavában Rimay úgy állítja be az elődköltőt, mint akinek munkásságát

\footnotetext{
${ }^{15}$ RADVÁNSZKY, Sztregovai Madách Gáspár versei, 132.

${ }^{16}$ Uo., 130.

${ }^{17}$ KLANICZAY Tibor, Hozzászólás Balassi és Rimay verseinek kritikai kiadásához, MTA I. OK, 1957, 283.

${ }^{18}$ Balassa-kódex, fakszimile kiadás, kiad. KöszEGHY Péter, betühív átirat, kiad. VADAI István, Bp., Balassi, 1994, 148. Modern átiratát ld.: RIMAY János Írásai, szerk. Ács Pál, Bp. Balassi, 1992 (Régi Magyar Könyvtár: Források, 1) [a továbbiakban: RJÍ], 55.

${ }^{19}$ Balassa-kódex, 175.

${ }^{20}$ SzILASI László, A sas és az apró madarak: Balassi Bálint költői nyelvének utóélete a XVII. század első harmadában, Bp., Balassi, 2008 (Humanizmus és Reformáció, 30).
} 
- jóllehet az aemulatio a korabeli alkotásmódszertan egyik alapvető technikája ${ }^{21}$ meghaladni nem lehet: „,nem tagadhatni, hogy mint a sas az apró madarak elött, úgy ö minden magyar elméjek előtt az magyari nyelvnek dicsősége fondamentumába való állásával felette elöhaladott s célt tött az pályafutásra, ezben az pályafutásban való serénkedöknek fel. "22

Az újabb kutatási eredmények tükrében úgy látszik, hogy a másfelől gyakorló diplomata Rimay elsősorban persze a saját költői nimbuszát igyekezett megteremteni. Ennek érdekében fogott hozzá a Balassi-kultuszt kiépítéséhez, mint a nagy költő nevezetes első számú tanítványa. ${ }^{23}$ Ebbéli privilegizált státuszát mesterének tulajdonított kijelentésekkel tette félreérthetetlenné. Ugyanakkor nem árt észrevennünk, hogy erre vonatkozó megjegyzés közvetlenül Balassi tollából ill. egyéb (Rimaytól) független forrásból nem ismeretes. Azt pedig, hogy bizonyos mitikus elemek éppen az említett szakrális hellyel és idővel kapcsolatban jelentek meg az irodalomtörténeti emlékezetben, hála néhány idevágó kitünő dolgozatnak, egy ideje szintén evidenciaként kezelhetjük. ${ }^{24}$

A kérdést, hogy Rimay János költészettörténeti jelentősége végül is meghaladta-e volna a Balassi Bálintét, a Balassa-kódex szövege tkp. nyitva hagyja. Állást csak az általa mostani poétáknak titulált szerzők ügyében foglal; méghozzá, mint láttuk, elég szkeptikusan. Az antologikusan bemutatott harmadik periódus (az összeállítás jelene) megítélése szerint a vaskoré. Ezzel a határozott, ugyanakkor némileg topikus kritikai narratívával szembesül tehát Radvánszky Béla, akinek saját emlékei szerint másodikként nyílott alkalma a szóban forgó sorokat végigolvasni. ${ }^{25}$

A fentiekben vázolt ellentmondás a korpusz rekanonizációja során természetesen föloldódott: Rimay és Madách költészetének tényleges - és nem mellesleg: a titokzatos művelt és irodalomkedvelő személy által is hangoztatott - színvonalbeli különbözősége az

\footnotetext{
${ }^{21}$ Vö. BÁN Imre, Az imitatio mint a reneszánsz arisztotelizmus esztétikai kategóriája = B. I., Költők, eszmék, korszakok, szerk. BITSKEY István, Debrecen, Kossuth Egyetemi Kiadó, 1997 (Csokonai Könyvtár, 11), 23-44.

${ }^{22}$ Madách-Rimay-kódexek, I, 44. Modern átiratát ld.: RJÍ, 49.

${ }^{23}$ Vö. SZILASI, i. m., 215-216.

${ }^{24}$ SzILASI László, Nyakvers = Sz. L., Miért engedjük át az ácsnak a házépités örömét, Bp., József Attila KörPesti Szalon, 1994 (JAK-füzetek, 72), 57-67; PALÁsthY Krisztina, Az LI. zsoltár világi és vallásos szöveghordozókban való megjelenése, kézirat, Pécs, 2015.

${ }^{25}$ Vö. RADVÁNSZKY Béla, Emlékbeszéd Deák Farkas $r$. tagról, Bp., 1895, 413. (A Magyar Tudományos Akadémia elhúnyt tagjai fölött tartott emlékbeszédek, VIII. kötet, 9. szám.) Idézi H. HuBERT Gabriella, $A$ sajókazai Radvánszky-könyvtár története, Szeged, JATEPress, 1998, 62. Madách Gáspár Rimay-követésének természetéröl ld. az appendixet (A Rimay-örökség Madách Gáspár tollán).
} 
életműveknek az addigiaknál jóval pontosabb körülhatárolásával vált igazolhatóvá. ${ }^{26}$ Eckhardt Sándor mindezekre alapozva konstatálta végül, hogy „Rimay és Madách Gáspár között elég nagy távolság van irodalmi müveltség és föleg tehetség dolgában ${ }^{27}-\mathrm{s}$ ezzel az összegzéssel maradéktalanul egyet kell értenünk. Csakhogy Eckhardt az alaki pongyolaságon és közhelyes gondolatvilágon túlmenően egy további jellemzőt is kirajzolódni látott a Rimay-életmüről leválasztandó anyagban, éspedig az alpári hangütést. Ezért úgy találta, hogy - szemben a korábbi szakirodalom engedékenységével ${ }^{28}$ - Rimay János „,költészetéböl el kell hagynunk szinte valamennyi verset és elmélkedést, mely a nemi élettel nyersebb vonatkozásban van; úgy látszik, Rimay puritán protestantizmusával csak a Balassa-kódexböl ismert udvarló szerelmes tónus fér össze, míg Madách Gáspár határozottan a nemi probléma körül ólálkodik és böven alkalmazza az érzéki leirásokat saját és keresi mások müveiben (Balassa János éneke, Bendö Panna éneke, Szerelemtül csak kár hogy tiltunk szép személt, Elmélkedés a paráznaságról.) „29 E bővebb koncepció széleskörü és tartósabb elfogadottságát jelzi, hogy egy évtizeddel később Pirnát Antal azzal teljes összhangban nyilatkozik e kérdésről a Magyar Irodalom Története vonatkozó passzusában: „Madách a maga szerényebb tehetségével az eddig kialakult magyar nyelvü énekköltés valamennyi müfajával kísérletet tett, mestere bonyolult költöi technikáját

\footnotetext{
${ }^{26}$ Eckhardt végül a kolligátumok öt füzetének anyagát idegeníti el Rimaytól. Így zárja ki többféle megfontolás szerint az I. kötet 2. füzetének 15 szerelmes énekét is. (Kritikai kiadása: RMKT XVII/12, 43-57. sz.) Ezek közül az egyik, hogy azokból ,egy sincs meg a Balassa-kódexben, ahol Rimay hiteles szerelmes verseit olvassuk.” A másik, hogy a nyilvánvaló tollhibák mellett a szövegben olyan ,önkényes javítások is akadnak, amilyeneket iróember csak a saját müveivel szemben engedhet meg. [...] Ilyen változtatásokat Rimay szövegén nem mert volna tenni bátyját nagyon tisztelö unokaöccse." A harmadik egy a versanyag nyelvállapotát érintő megfigyelés: „Rimay sosem rímeli az '-at' tárgyragú végzödést '-ad' végü más szavakkal, mert nála ez a végzödés, mint Balassinál csak '-ot' alakban szerepel." A fentiek értelmében ezért Eckhardt arra az álláspontra jut, hogy „[a] Madách Gáspár másolataiban szerepö szerelmes versek pedig, melyeket Radvánszky Béla Rimaynak tulajdonitott, kivétel nélkül Madách versei, tehát Rimay kiadásában nem foglalhatnak helyet", merthogy „,semmi okunk nincs arra, hogy [azokat] ne Madách Gáspár verseinek tekintsük.” (RÖM, 162-164.) Kizárja az 5. füzet énekeit is, melynek tartalmát zömmel az ún. Cato-fordítások teszik ki (34. sz.), valamint egy Cato-szentencia hosszabb parafrázisa (Feleséget ne végy magadnak jószágért... , 23/I. sz.) és egy kegyes ének. (Az hit remélendö dolgoknak állatja..., 8. sz.) Kizárja a II. kötet 1. füzetében olvasható Cato-parafrázisokat is (22/I-II, 23/II, 24-33, 35. sz.), és a rákövetkezö vegyes részt. Ezek közül a Szodomához hasonló paráznák hajléka... kezdetü alkotásról (39. sz.) azt írja, ,szintén Madáchénak látszik rossz rímeivel, ritmusával és törléseivel." A Dicsíret c. költemény (Ó, Jehova, szent Istenem..., 1. sz.) szerzőségét a sajátkezű datálásban megjelenő személyrag alapján származtatja Madáchtól, a Nagy Isten ajándéka... és az $O$, csalárd világ, mit cselekeszel... kezdetüeket (35. ill. 37. sz.) pedig a kétszeri kidolgozás okán. A Pöngését koboznak gyakran ha te hallod... (58. sz.) kezdősorú tétel attribuálásából kiérezni némi kétkedést: „,Madách legsikerültebb verse, ha ugyan töle való." A Bendö Panna komáromi asszony éneke c. (40. sz.) tulajdonításában már egy újabb szempont lép életbe: „Madáché lehet, hiszen ö az obszcenitástól máshol sem riadt vissza.” (RÖM, 165.) Ami éppenséggel igaz volna a Balassa János éneke sólymocskájárúl c. versre (41. sz.) is, csakhogy azt már ezt megelözően, Balassi Bálint müveinek kritikai kiadásában a költő apja (Balassa János) v. annak íródeákja (Rimay Gergely) munkájának ítélte (Vö. BÖM, 279.). Újfent a javítások mennyiségére és jellegére hivatkozva (vö. RÖM, 165.) végül kizárja a 4. és 6. füzet moralizáló elmélkedéseit (RMKT XVII/12, 675-714).

${ }^{27}$ RÖM, 3.

${ }^{28}$ Rimay századeleji biográfusa, Ferenczi Zoltán a rút vagy egyenesen piszkos célzásokat még az öreges szabadnyelvüségnek tudja be. FERENCZI Zoltán, Rimay János, Bp., Athenaeum, 1911 (Magyar Történeti Életrajzok), 120.
}

${ }^{29} \mathrm{RÖM}, 166$. 
azonban már nem tudta elsajátítani, verselése nehézkesebb, Rimay költészetéhez képest új szint csak néhány versének durván erotikus motívumai képviselnek. ”30

Az obszcenitás megítélése persze koronként változó; ${ }^{31}$ ahhoz azonban tényleg nem férhet kétség, hogy a felsorolt írásművekre jellemző keresetlen modor - protestáns puritánságból vagy sem - teljesen idegen Rimay János költői habitusától. Azzal együtt mégis érdekes, hogy amikor Gerézdi Rabán röviddel a Kézikönyv megjelenése után egyszer csak rádöbben, miféle jelentésrétegeket tartogat még a Balassa János éneke a befogadók számára, és ez alapján a szerzői intenciót a parodisztikusságban ragadja meg, akkor ebbéli felismeréseit látványos felháborodással teszi közzé. ${ }^{32}$ Pedig az általa vehemensen emlegetett öncélú pornografikusság hipotézise voltaképpen ennek a megközelítésnek a segítségével számolható fel csak igazán. Ennek alátámasztására - anélkül, hogy a szerzőség kérdésire most kitérnék -, javaslom, tekintsük át az inkriminált opuszok katalógusát.

A Balassa János éneke c. költemény - Gerézdi interpretációját követve mindenesetre - egy felajzottságát a szerelmi költészet kliséinek fogalmatlan alkalmazásával tolmácsoló férfiember nevetséges alakja rajzolódik $\mathrm{ki}^{33}$ A Bendö Panna éneke egy félvilági nő erkölcstelenségét prédikálja világgá. A Szerelemtül csak kár... kezdetű vers recepciója a benne foglalt állítások (miszerint a fiatal menyecskék előszeretettel létesítenek szexuális kapcsolatot időskorú férfiakkal) képtelensége miatt szintén a Balassa János énekéhez hasonlatos; a tekintetben is, hogy a beszélő ebben sem igen válthat ki szimpátiát a közönségéből. ${ }^{34}$ Végül A parázna életről írott traktátus olyan radikális és életidegen prüdériával kárhoztat mindenféle (nem csak testi) érintkezési lehetőséget férfiak és nők között, hogy annak megtartása jószerével az emberiség kihalásával fenyegetne. ${ }^{35}$ Mindezek figyelembevételével azt kell gondolnom, hogy a nemiség mintha tényleg problémaként

\footnotetext{
${ }^{30}$ A magyar irodalom története 1600-tól 1772-ig, 37.

${ }^{31}$ Erre figyelmeztet a korpusz kapcsán Jankovics József is. Vö. JANKOVICs József, A Madách Gáspár-jelenség: Erotikus költészetünk regiszterei = J. J., Ex occidente...: A 17. századi magyar irodalom európai kapcsolatai, Bp., Balassi, 1999 (Régi Magyar Könyvtár, Tanulmányok, 3), 48-59.

${ }^{32}$ GERÉZDI Rabán, , Balassa János éneke solymocskájárul”, ItK, 1965, 689-693. Gerézdi e tanulmánya nyomán válik többé-kevésbé koszenzuálissá a szóban forgó éneket Madách Gáspárnak tulajdonítani. A bizonytalanságot önmagában is jelzi, hogy Varga Imre, aki a kritikai kiadásban rendezőelvként jobb híján egyedül a szerzőség esélyét tudja alkalmazni, a Balassa János énekét az utolsó előtti helyre (RMKT XVII/12, 41. sz.) sorolja.

${ }^{33}$ Meg kell jegyeznem, hogy a vers számos motívuma (így a madárka kézbe vétele, jóllakatása, balzsamozása, vetett ágyba fektetése, stb.) megjelenik a Fanchali Jób-kódexben fennmaradt Bože, požal toho... kezdetű szerelmi énekben is. (Bilingvis kritikai kiadását ld.: Ján MiŠIANIK, ECKHARDT Sándor, KLANICZAY Tibor, Balassi Bálint szép magyar komédiája: A Fanchali Jób-kódex magyar és szlovák versei, Bp., Akadémiai, 1959 (Irodalomtörténeti füzetek, 25), 180-185.) Ez a tény pedig még inkább alátámasztja a Balassa János éneke parodisztikus voltát; ezúttal müfaji vonatkozásban is.

${ }^{34}$ Ld. a vonatkozó éneket (Szerelemtül csak kár...) tárgyaló részfejezetet.

${ }^{35}$ Horváth János is (még Rimaynak tudva e munkát) a középkorias szellemét konstatálja. Vö. HoRVÁTH János, Hír három virágénekröl, MNyelv, 1949, 1-10. Ua. = H. J. Irodalomtörténeti munkái, kiad. KOROMPAY H. János, KOROMPAY Klára, II, Bp., Osiris, 2006 (Osiris Klasszikusok), 517-527.
} 
tételeződött volna Madách Gáspár számára - ugyanakkor ez az attitűd inkább a „, szerelemviszolygásé, ${ }^{36}$ mint a kedvcsinálóé.

Noha a fentihez hasonló relativizáló megközelítések sokáig nem jelentek meg az attribúciót övező vitában, az obszcenitás e megoldatlan problematikája egy időre mégis kiszorult abból. ${ }^{37}$ Madách Gáspár költői profiljának az említett két meghatározó vonása közül a soron következö, igen alapos hozzászólás is a másikat teszi próbára a hagyatékon. Bóta László kutatásai homlokterében az aktuálisan éppen Madáchénak tudott tizenöt szerelmi tárgyú ének áll, a többi munkát pedig mintegy kontrollanyagként veszi hozzá. ${ }^{38}$ Az összehasonlítás eredményeként arra derül fény, hogy e füzet tartalmát illetően korábban Eckhardt által is regisztrált nagyszámú zavaros értelmű szöveghelyről és metrikai pontatlanságról kizárólag a másoló tehet, aki - ha észlelte egyáltalán az általa elkövetett hibát - utólagos korrigálásaival jobbára tovább rontott a helyzeten. ${ }^{39}$ A szerelmes énekek szövegének emendálásával Bóta kétségbevonhatatlanul bebizonyítja, hogy azok eredetileg többnyire hibátlan formában, méghozzá négysarkú felező tizenkettesben, a Palkó-vers ritmusára ill. Balassi-strófában íródtak. Mindezekből pedig egyenesen következik, hogy a másoló, vagyis Madách Gáspár nem tartozhat a feltételezhető szerzők körébe. Bóta a továbbiakban aprólékos és sokrétü (frazeológiai, stilisztikai, verstechnikai, stb.) analízisnek veti alá a verscsoportot, és végül arra a megállapításra jut, hogy mivel az kiugró intenzitással reprezentálja Balassi Bálint és az eminens Rimay János költészetének jellegzetes ismérveit, ezért megalkotása egyedül ez utóbbinak tulajdonítható. ${ }^{40}$

Kereken egy évvel ezután jelenik meg a Madách Gáspár-i életmű esedékes kritikai kiadásának előtanulmányaként Varga Imre dolgozata. Ebben Varga a szerelmes versek szerzőségének imént vázolt megoldását illetően leszögezi, hogy azt csak részben tudja elfogadni. Mint írja, az a fö kifogása Bóta eljárásával szemben, hogy „az ilyen jellegü vizsgálódások határozottabb bizonyitékokat csak akkor szolgáltatnának, ha Madách

\footnotetext{
${ }^{36}$ KLANICZAY Tibor, A reneszánsz válsága és a manierizmus, ItK, 1970, 428.

${ }^{37}$ És majd csak Jankovics már idézett dolgozatában tér vissza, vö. 31. lábjegyzet.

${ }^{38}$ Vö. BóTA László, A Madách-Rimay-kódexek szerelmes versei, ItK, 1967, 1-24.

${ }^{39}$ Eckhardt megállapításával szemben (,,Ilyen változtatásokat Rimay szövegén nem mert volna tenni bátyját nagyon tisztelö unokaöccse,” RÖM, 164.) Bóta úgy véli, hogy „, a másoló, ha szükségét látta, nem idegenkedett Rimay szövegének módositásától sem.” (BóTA, i. m., 9.) Föltünő ugyanakkor, hogy a hiteles Rimay-alkotások másolatai adott esetben szinte nem is tartalmaznak utólagos javításokat. Ez alighanem azzal magyarázható, hogy Madách ha pontatlanul is, de nagy gonddal és általában több fázisban dolgozott. Ha tehát a forrás eközben huzamosabb ideig rendelkezésére állt, akkor módjában állhatott ennek alapján kijavítani az értelmi ill. metrikai rontásokat, ha viszont nem, akkor saját emlékezőtehetségére és kreativitására volt utalva. Nem mellesleg a tizenöt szerelmes vers lendületes írásképe amúgy is gyors lejegyzésre utal.

${ }^{40}$ Bóta ilyen irányú megfigyeléseire a korpusz tüzetes tárgyalása során térek ki tételesen.
} 
Gáspárnak is ismernénk annyi szerelmes versét, mint amennyit ismerünk Rimaytól, Balassitól. [...] Az istenes, oktató, elmélkedő, gondolati költészet pedig egész más szó- és képanyaggal dolgozik, mint a szerelmi." "41 Csakhogy ez az okfejtés így biztosan nem állja meg a helyét. Hiszen valójában - mint majd látni fogjuk - Bóta László nemcsak Rimay János hitelesnek tekintett szerelmes énekeivel vetette össze a kérdéses verscsoportot, hanem a Rimay- (és Balassi-) anyag egészével. Miért is szorítkozott volna erre, amikor gyakran éppen olyan kifejezésbeli paralelizmusok kimutatásában volt érdekelt, melyek szókészlete egyébként sem tartozik a korabeli szerelmi költészet legtipikusabb fordulatai közé? (Pl. jel, kenyér, zápor, stb. ${ }^{42}$ )

Azonban Bóta másik, a verstechnikára vonatkozó megállapításait Varga Imre is kénytelen akceptálni. E megfontolások alapján hozza meg a szerkesztői döntését, ami bizonyos szempontból joggal nevezhető „,salamoninak”: ${ }^{33}$ „Bóta érvelését nem tartjuk elég meggyözőnek ahhoz, hogy az I. k. 2. füzetének szerelmes verseit Rimay nevéhez kössük, de elegendőnek tartjuk ahhoz, hogy e verseket elválasszuk Madách Gáspár nevétöl."44 A Régi Magyar Költők Tárának a Madách-életmüvet is tartalmazó 12. kötete végül majdnem húsz évvel e tanulmány közreadása után, 1987-ben jelent meg. Az idézett (s a jegyzetapparátusban szóról szóra megismételt ${ }^{45}$ ) részlet értelmében a tizenöt szerelmes ének abban végül $A$ Madách-Rimay-kódexek ismeretlen szerzőtől származó versei gyüjteményes cím alatt látott napvilágot.

E dolgozat voltaképpeni tárgyát a Madách-Rimay-kódexek Szerelmes énekek címet viselő füzetének anyaga képezi. Ahogy azt az előzőekben volt alkalmam kifejteni, a mai napig nem sikerült megválaszolnunk a tizenöt verssel kapcsolatos zsigeri kérdést: a szerzőségét csakhogy ez éppen nem az eddigi kutatások során (már ha egyáltalán) elkövetett módszertani hibák következménye. Ellenkezőleg: ezt a kritikai teljesítményt az egyre figyelmesebb megközelítések eredményeként könyvelhetjük el. Azzal együtt tartok tőle, hogy ha ez idáig nem sikerült felfedni a költemények szerzőjének kilétét, akkor ez a feladvány a továbbiakban sem kecsegtet minket sok reménnyel. Ezért föl kell vetnünk: ebben az esetben mi haszna lehet a választott szövegegyüttes újraolvasásának?

\footnotetext{
${ }^{41}$ VARGA Imre, $i . m$.

42 BÓTA, i. m., 11-17.

${ }^{43}$ Nagy Ferenc, Holtdudvar, szakdolgozat, Szeged, 2006, 4.

${ }^{44}$ VARGA, i. m., 70.

${ }^{45}$ RMKT XVII/12, 668-669.
} 
Amikor Imre Ilma a már idézett monográfiájában a 20. század elejére számos apokrif tétellel kontaminálódott Balassi-szöveghagyományból eltávolította a Vásárhelyi Daloskönyv őrizte énekanyag megalapozatlanul oda sorolt részét (kereken 30 darabot $^{46}$ ), az eljárást kísérő legfontosabb reflexiója minden bizonnyal annak hangsúlyozása volt, hogy a korpusz ilyetén fogyatkozása nemhogy elhalványítaná, hanem inkább fokozza Balassi költészettörténeti jelentőségét. A költői ouvre jelentőségével önmagában a mérete nincs összefüggésben - annál inkább a befolyása alatt született utódszövegek mennyisége. ${ }^{47}$ Ez persze nem kizárólag Balassi Bálintra és a Vásárhelyi Daloskönyv névtelenjeire érvényes diagnózis, hanem általánosan is kiterjeszthető alapvetés, amelyre a szükséges konzekvenciák levonása után magam is építkezni szeretnék, miközben az ehelyütt vizsgálandó anyaghoz, vagyis a kolligátumok tizenöt szerelmes verséhez próbálok közelíteni. A korábbi szakirodalom - láttuk - elsősorban az abban fellelhető Balassi- v. hiteles Rimay-reminiszcenciák megállapításában volt érdekelt (máskülönben pedig az egyéb lehetséges mintákat alig figyelte), és csak kevésbé azok értékelésében. Dolgozatomban ezért az adatolás elvégzése után a feltételezett áthallások jellegének értelmezésére igyekszem az eddigieknél nagyobb hangsúlyt fektetni.

Főbb kérdéseim a következőek. Hogyan kontextualizálhatók ezek az énekek? Hogyan viszonyulnak elődszövegeikhez? Milyen retorikai-poétikai eszközöket ill. megoldásokat kölcsönöznek azokból? Miként alkalmazzák ezeket? Úgy gondolom, hogy az erre adott válaszok csomópontjaiból olyan profil rajzolódhat ki, mely alapján próbára tehetjük a szerző identifikusságát - akkor is, ha megnevezni továbbra sem tudjuk.

De talán valamivel többről is lehet szó. Zemplényi Ferenc Az európai udvari kultúra és a magyar irodalom c. értekezésének neuralgikus pontján említi a füzet énekeit: annak fejtegetése során, hogy a régi magyar irodalomra nemcsak Balassi fellépéséig volt jellemző az arisztokratikus regiszter hiányából adódó féloldalasság, hanem a korabeli intézményrendszer kialakulatlansága miatt azt követően is. Mint írja, „Balassi köré egyre nagyobb és egyre tágabb életmü, egyre bizonytalanabb és egyre átfogóbb szöveghagyomány kezdett épülni, ami életmüvének későbbi, fokozatos popularizálódását jelentette, felolvadását a 17. század félpopuláris nemesi dalköltészetében. Rimay életmüve nemcsak Balassiéval keveredett nehezen kibogozható módon, de Madách Gáspáréval is, még komplikáltabban. Ugyanakkor egyáltalán nem ismerjük tanítványaikat, Balassi akadémiájának egykori tagjait (nevüket is

\footnotetext{
${ }^{46}$ Vö. BALASSI Bálint minden munkái, kiad. DÉzsI Lajos, Bp., Genius, [1923], II, 222-268.

${ }^{47}$ Vö. ,Legfrappánsabb bizonyitékai annak a ténynek, hogy nemcsak ismerték, de követték és utánozták is öt oly mértékben - és valljuk be - oly ügyesen, hogy az utókor jeles buvárait is meg tudták téveszteni." IMRE Ilma, Balassi Bálint hatása a XVII. század névtelen költöire (A Vásárhelyi daloskönyv alapján), Bp., [Franklin], 1930, 5 .
} 
csak olykor), életmüveiket rekonstruálni nem tudjuk, legfeljebb a Madách-Rimay-kódex bizonyos darabjainak attribuálásánál lesz gyanús, hogy egy-egy kétségtelenül e körbe tartozó darab vagy sorozat talán sem Madáchnak, sem Rimaynak nem tulajdonitható. „48

Ebből pedig - ha jól értem - az következik, hogy a Zemplényi által e tekintetben kivételesnek tartott szövegek ilyen érdekű tanulmányozásával az eddigieknél valamivel részletesebb képet alkothatunk egy, a Balassi Bálint és Rimay János irodalmi munkásságának közvetlen hatása alatt álló költöi iskola praxisáról is.

A bevezetéshez tudós kollégám, Vadai István egy számomra régóta kedves katonatörténete szolgáltatta a címet, amely szerintem kitünő allegóriája a dolgozatom tárgyául választott problémakörnek. Vadai a sorkatonai szolgálatát annak idején Hódmezővásárhelyen töltötte. Tudnivaló, hogy a Magyar Néphadsereg nagy gondot fordított arra, hogy a kiképzés során ne csak a gyakorlatban biztosítson harcászati jártasságot az újonc állománynak, hanem az ahhoz szintén nélkülözhetetlen elméleti ismeretekben is részesítse öket. A regrutáknak ezért be kellett magolniuk az alapfelszerelésük rendeltetésszerü használatára vonatkozó elöírásokat, valamint ezzel szoros összefüggésben e kellékek egyes alkotóelemeinek szakszerü megnevezését is. Így tudta meg Vadai, hogy a rendelkezésére bocsátott kincstári látcső két összetevőből áll: az egyik a tok, a másik pedig maga a látcső.

Mindez aligha szorulhat bővebb magyarázatra. Egyrészt a tokkal kétség kívül számolni kell, ám az csupán tartozéka, nem pedig része a látcsőnek. Másrészt a látcső valójában számos további alkatrészre bontható (pl. tárgylencse, prizmák, okulár, stb.), csakhogy ezekröl a túldefiniálásra amúgy igencsak hajlamos katonai szakirodalom mélyen hallgat. Nyilván abbéli megfontolásból, hogyha ezt a - teszem azt: a gyalogsági ásóhoz mérten - tényleg komplikált és érzékeny müszert valaki esetleg szétszerelné, minden esély megvan rá, hogy azt többé már senki nem igazíthatja helyre.

Ezt a történetet először akkor hallottam tőle, amikor idestova tíz éve - és biztosan egy csütörtöki napon - Ötvös Péter és Szilasi László társaságában Szegedröl Pécs felé igyekeztünk egy esti szemináriumra. Jó volt velük utazni.

Jelzem, hogy a látcsövet, amit a kezembe vettem, elég sokszor szedték szét és próbálták meg újra összerakni, hovatovább a pontos szerkezeti rajz ismerete nélkül és az alkotóegységek eleve foghíjas készletből gazdálkodva. Jelenleg ezért biztosan nem a valóságot mutatja,

\footnotetext{
${ }^{48}$ ZEMPLÉNYI Ferenc, Az európai udvari kultúra és a magyar irodalom, Bp, Universitas (Historia Litteraria, 4), $1998,62$.
} 
hanem - akárha egyfajta kaleidoszkóp volna - csak a torzképét annak. A részletek elvileg végtelen számú mintázata közül, melyeket ebbéli minőségében kinyerhető belőle, valamennyit már ismerünk. A következőkben magam is csupán néhány további lehetséges konstellációt próbálok felvázolni. Teszem mindezt abban a reményben, hogy e képek összessége közelebb visz majd egy összeállni sohasem képes egészhez, mielött a teljes apparátus egy időre megint visszakerülne a tokjába. 
A Madách-Rimay-kódexek Szerelmes énekek c. füzetéről készült digitális fotokópia ${ }^{49}$

${ }^{49}$ 2008-ban Szilasi László megbízásából az OSZK Digitalizáló Osztálya nagy felbontású fényképeket készített a kolligátumokról. Ezekből adom közre melléklet gyanánt a szóban forgó füzet 17. egységének beírt lapjait. A szelvényeket jobb tanulmányozhatóság kedvéért a lehetőségekhez mérten kinagyítottam: a levelek mérete a valóságban $\mathrm{kb} .200 \times 80 \mathrm{~mm}$. Mindezt azért tartottam fontosnak (némiképp rendhagyó módon) a dolgozatom elejére illeszteni, mert voltaképpen ezen alapszik a lényegi rész; vagyis az egyes versek értelmezéseinek menete. 


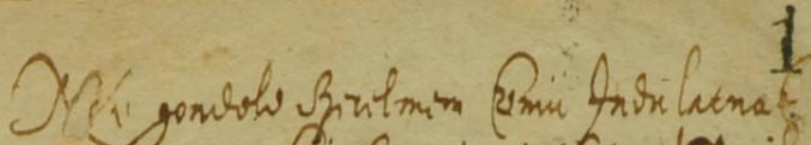

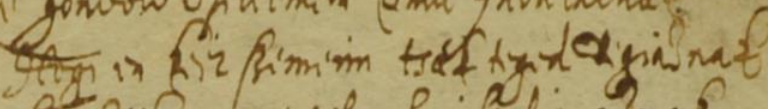

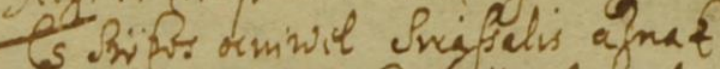

If Effin it withn thin ham latras

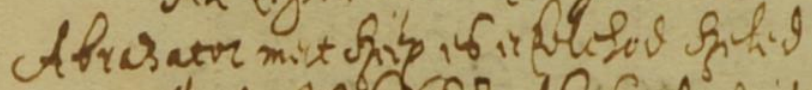

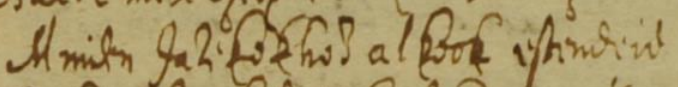

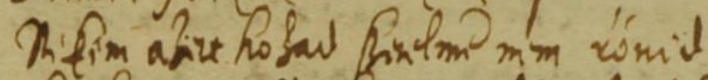

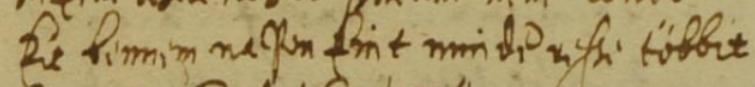

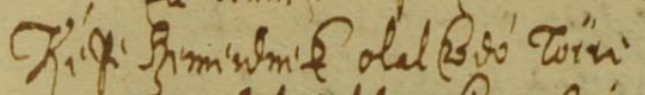

Thm Schunltat of in Sumim filloh.

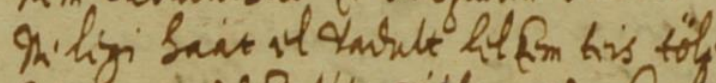

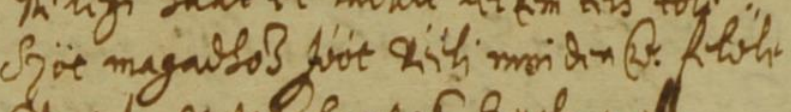

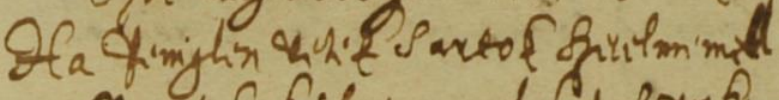

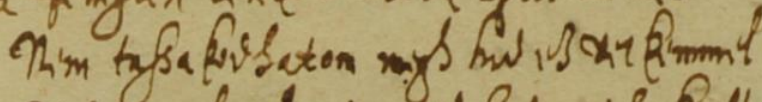

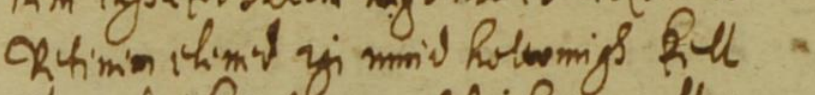

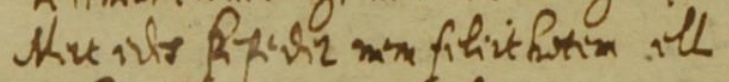
ast Pontivlanian m' osat myant

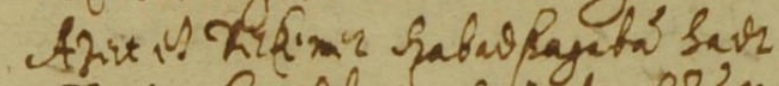

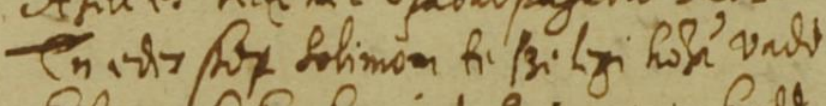

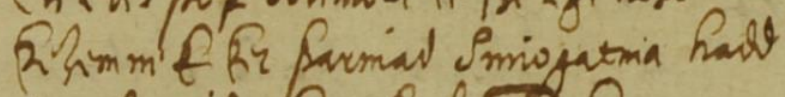

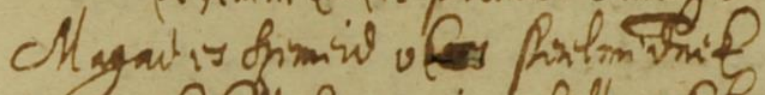

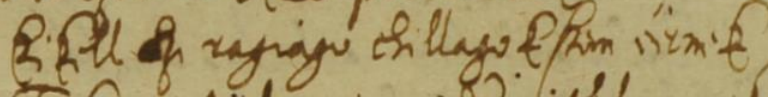

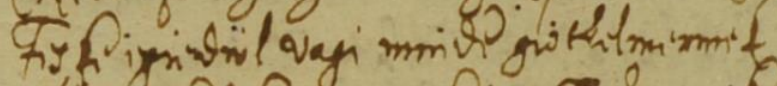

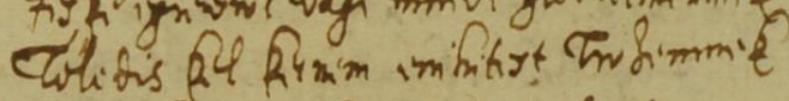

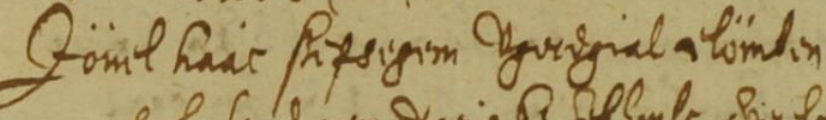

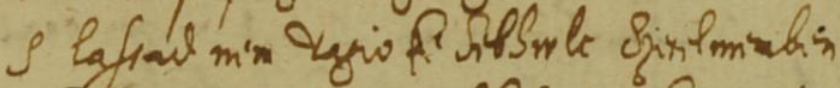

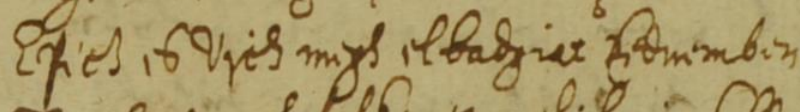

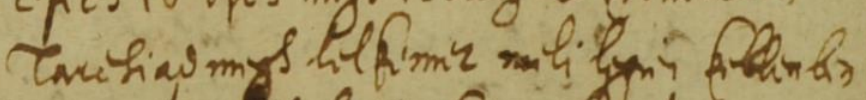

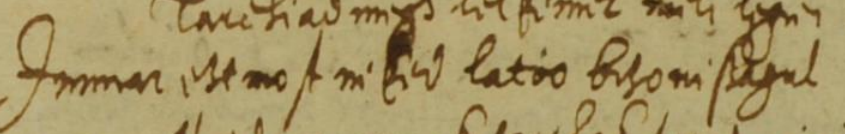

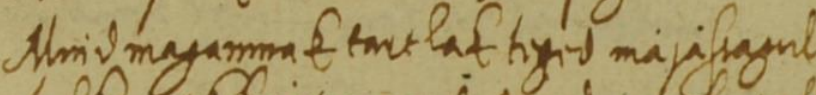

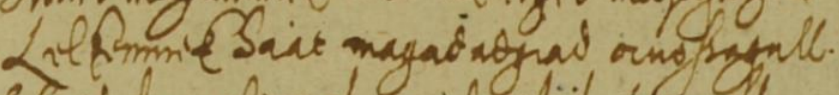

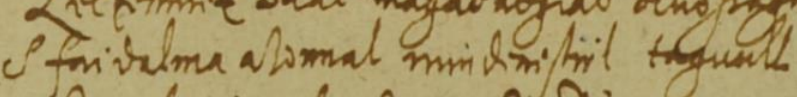

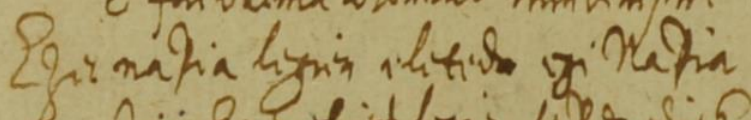

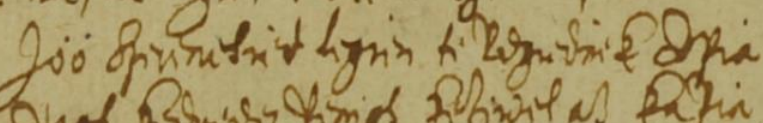

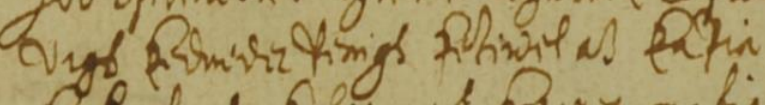

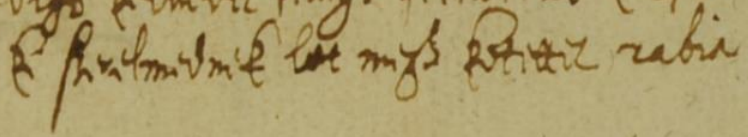
thias 


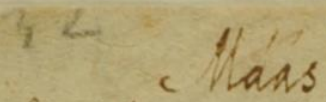

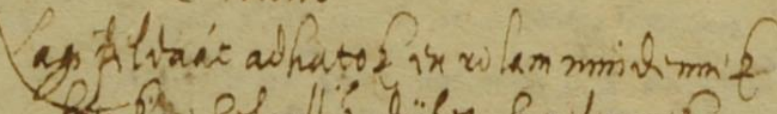

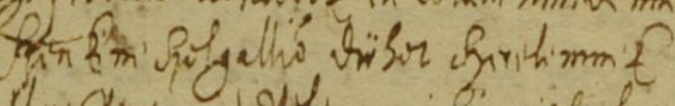

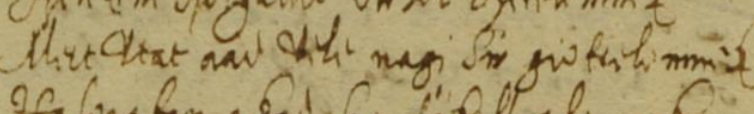

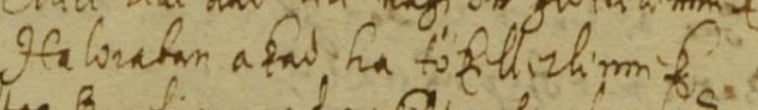

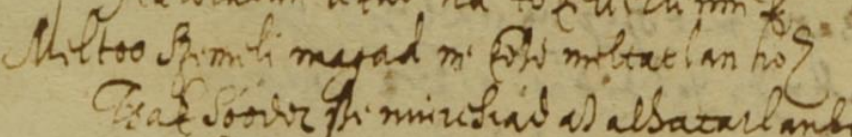

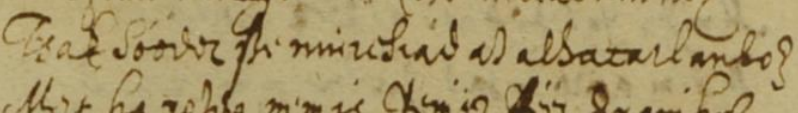

Whit ha roha mim is Xinin fir tramino?

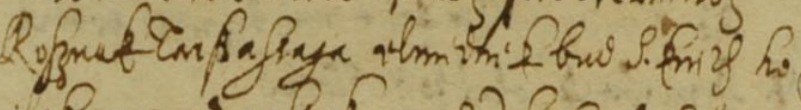

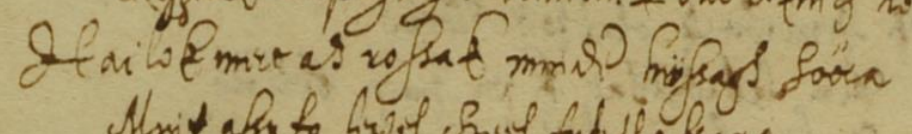

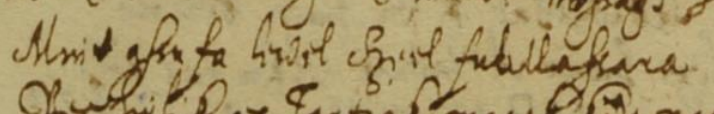

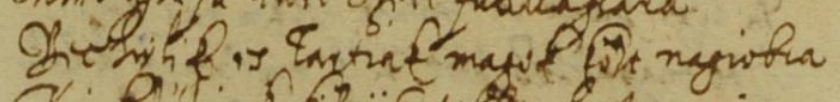

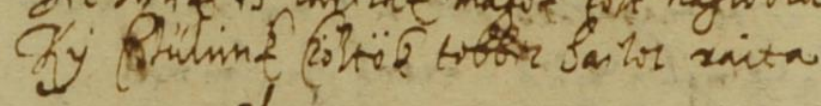
chass

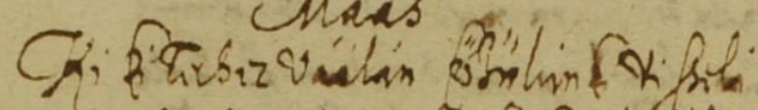

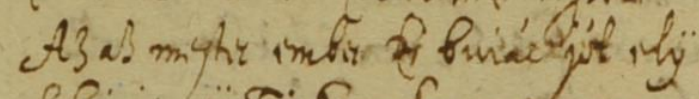

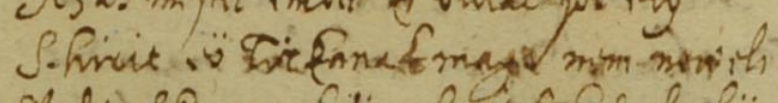

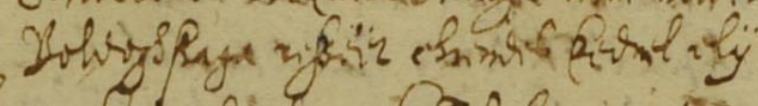

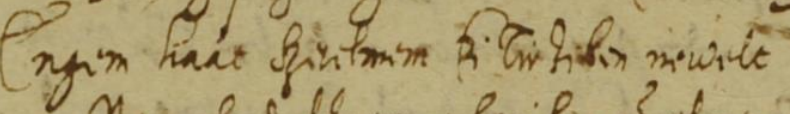

Thim sombllsatom Sog lang it min milt

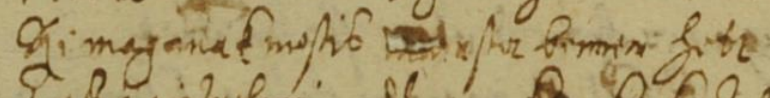

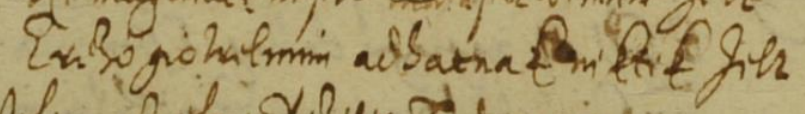

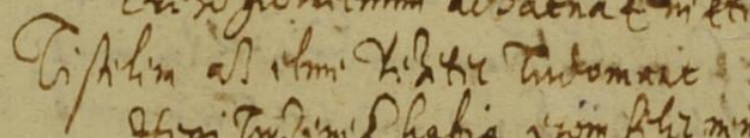

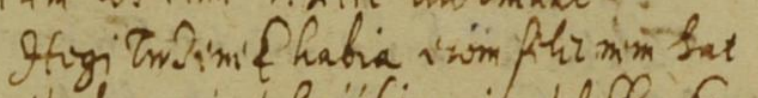

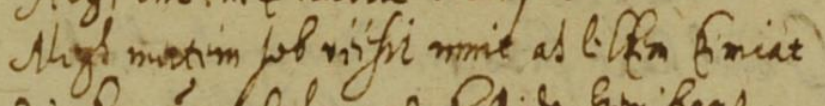

wiafmió mifalam as fipios sim baxl

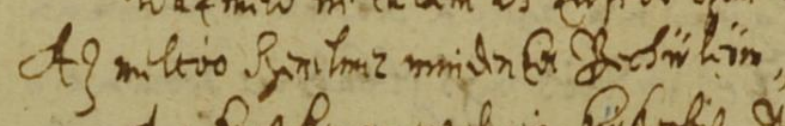

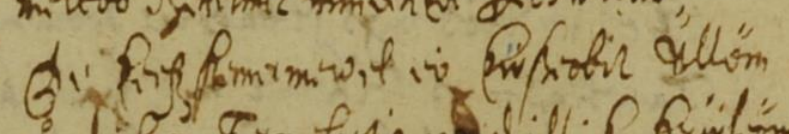

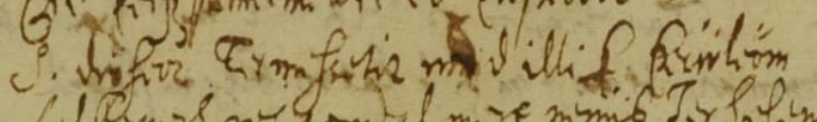

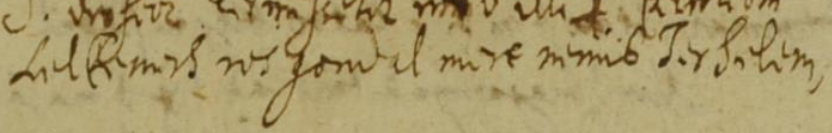

Clins 


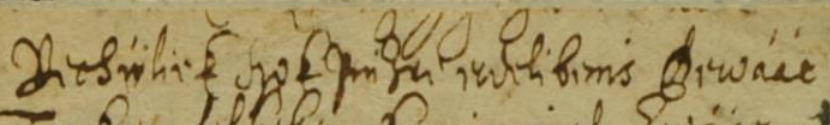

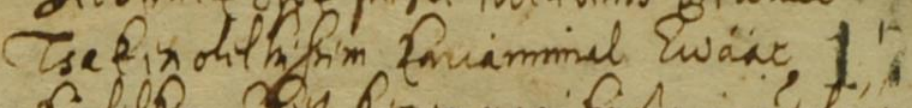

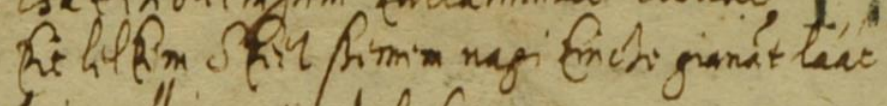
Af io fini mithi niv alebaforim

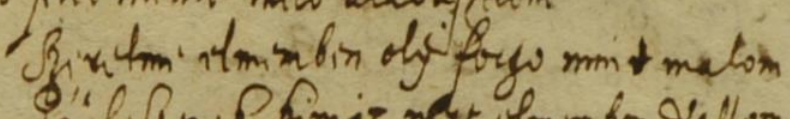

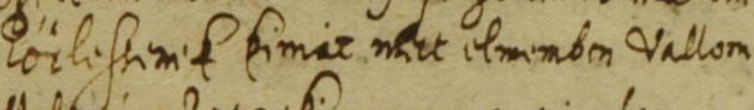
Mlenix ahit nif mayamor simlom

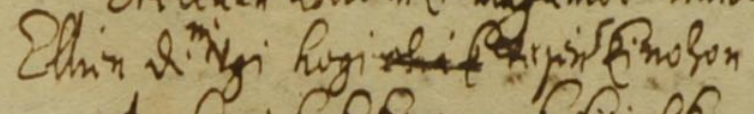

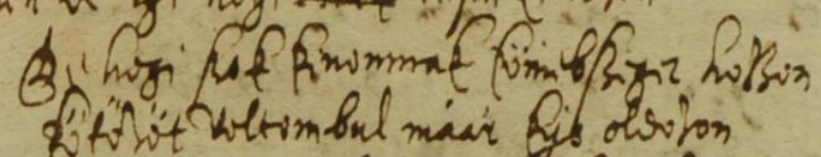

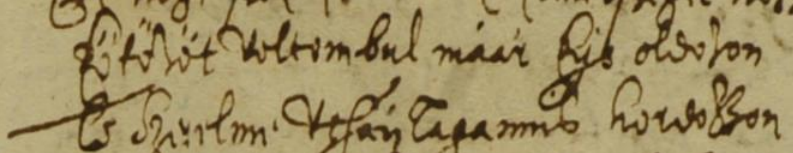

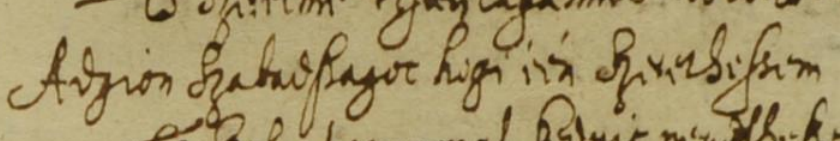

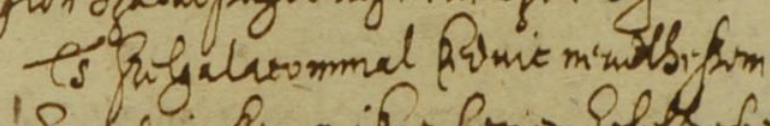
Ingingi Pit malar hor in Oohts figm

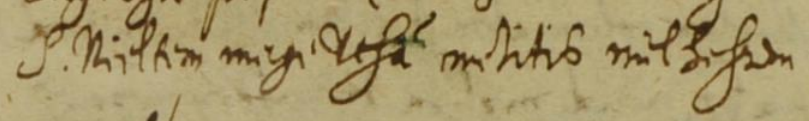

- claas

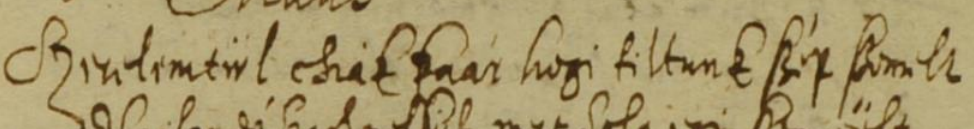

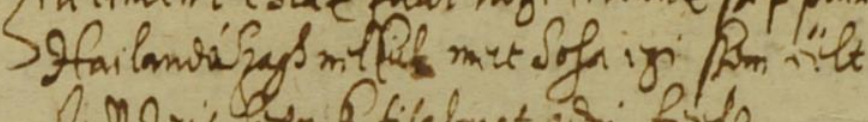
fuphris ortm f filalmat asm firls

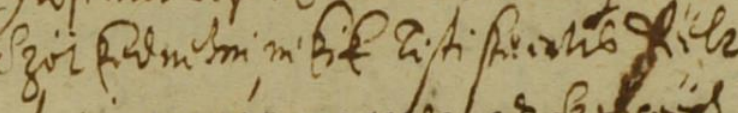
Aimlatia myát manalial as oubsings

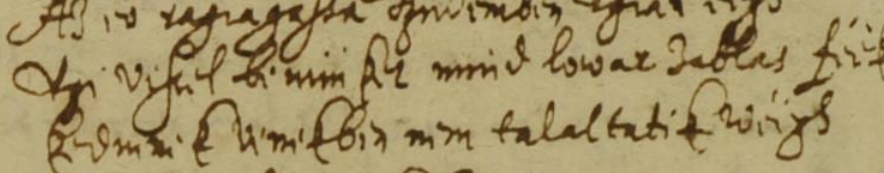

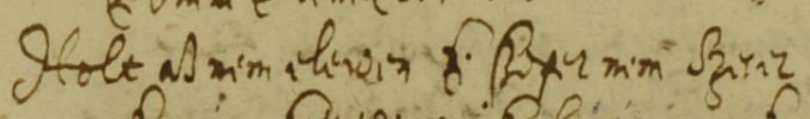

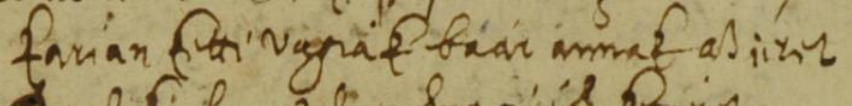

2. as fif forwal ragsat miys Rominz

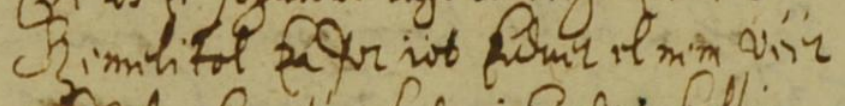

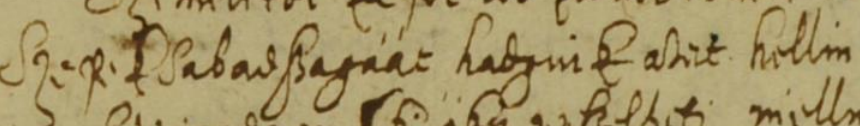

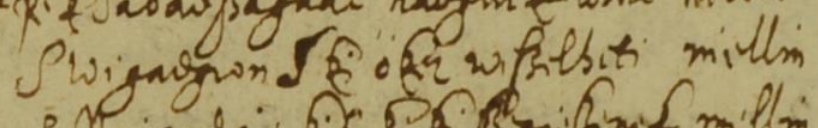

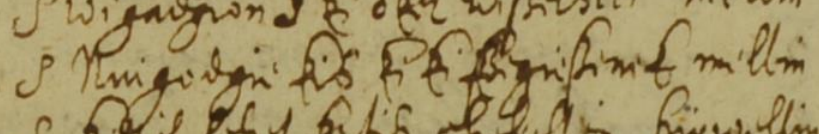

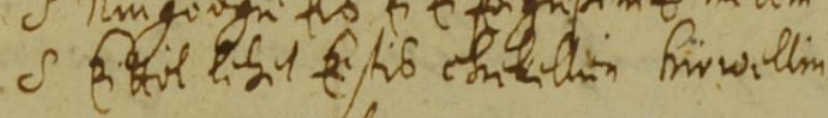
Alans ofimmi 


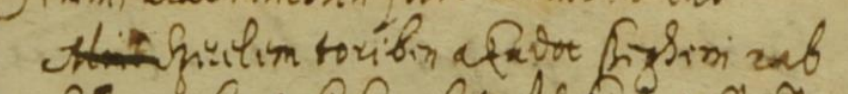

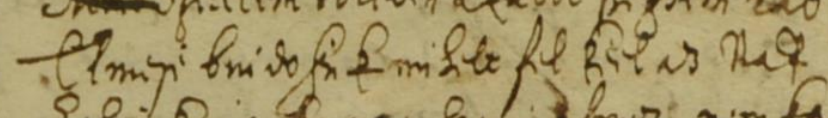

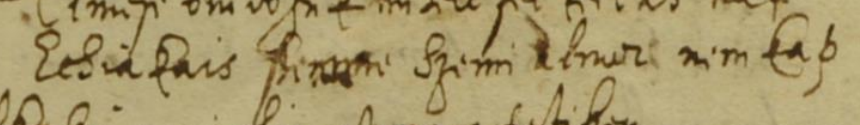

Lllo Grin michor alumaga tifibin

clophish man' omit Shutoibin

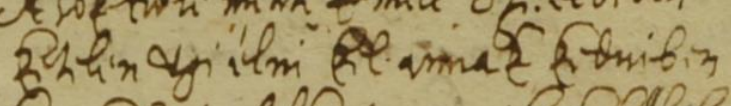

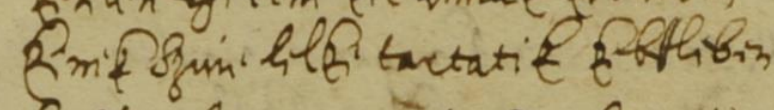

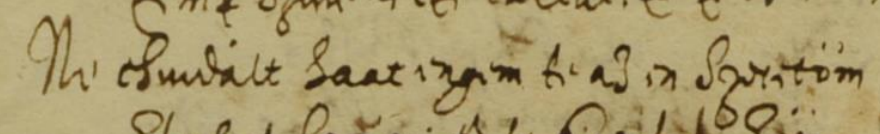

Qhys as hog mincs h. Fivolit oivm

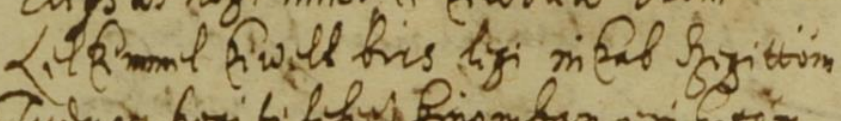

Prit ilitingim as ti Ric formy

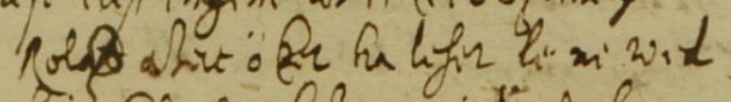

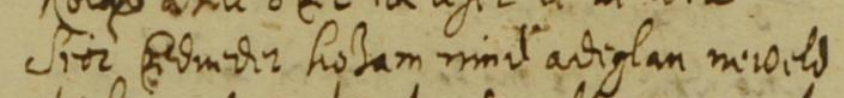

Miglin tolim alor tind imilit mincl

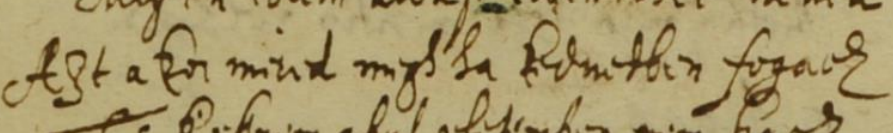

Biffrim abl ahtimbix mim har

Ifig hoj hiv Polyare Rokroiglam a farer

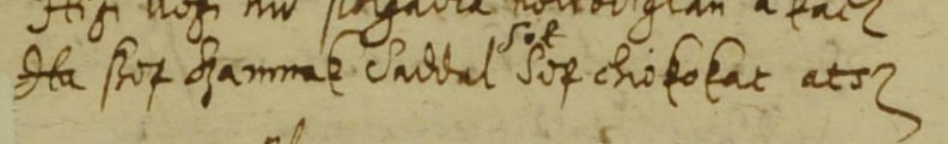

ollas

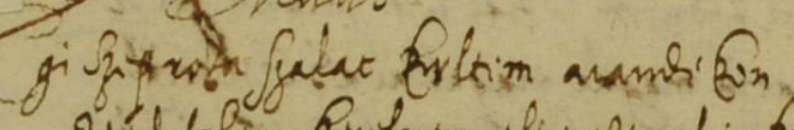

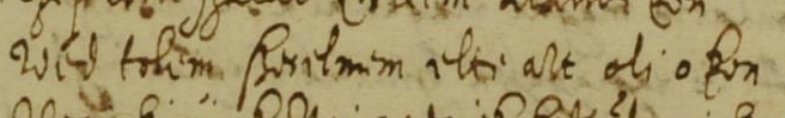

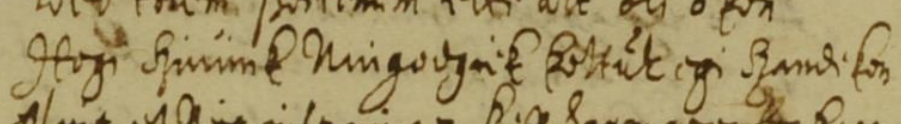

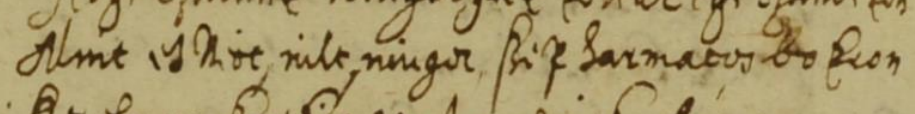

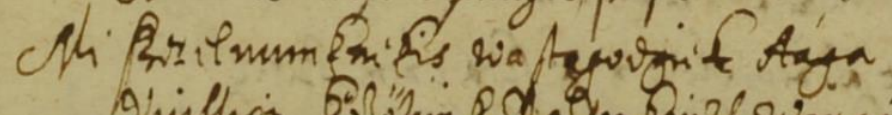

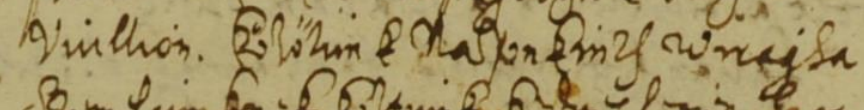

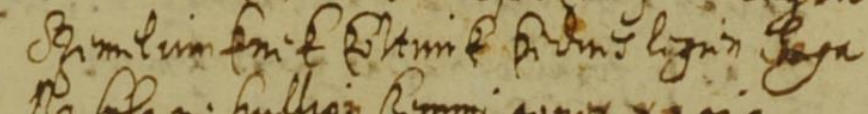

Nafofa m Amllog form gunos vagia

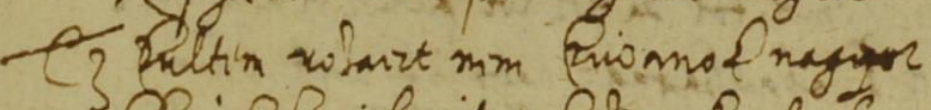

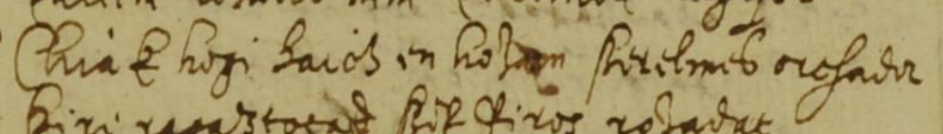

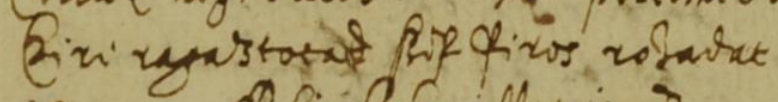

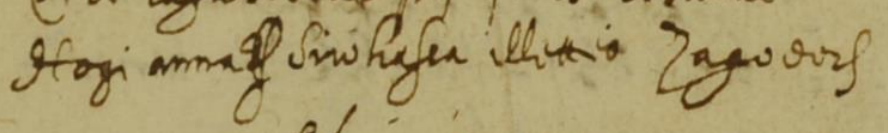
cllaas

<atev 
foricetas andit fom

Towagnom in than 6 .

18

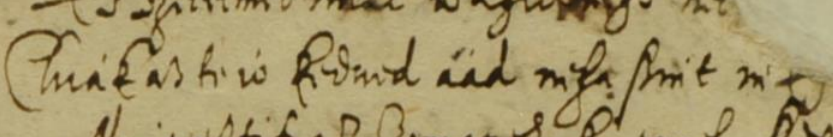

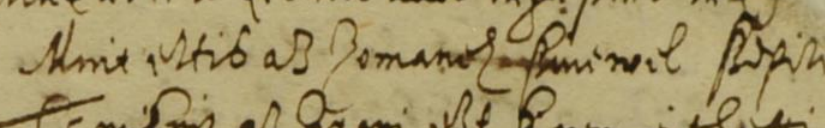

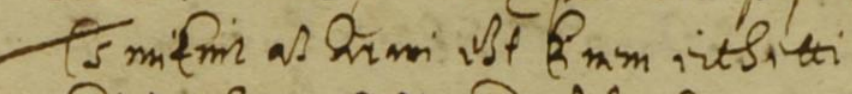
Rethis siminit os $m$ fhifits

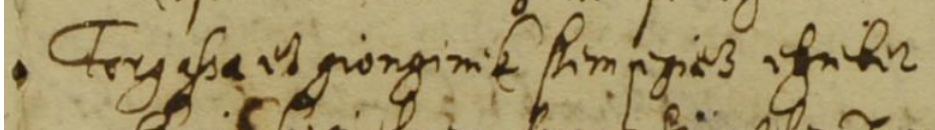
Imiflug 1 mim fryat Binmalom zigar

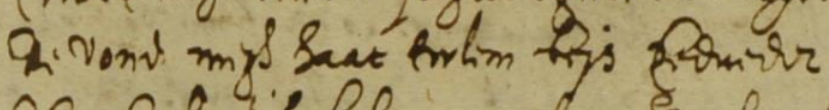

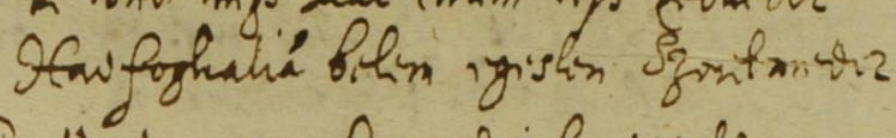

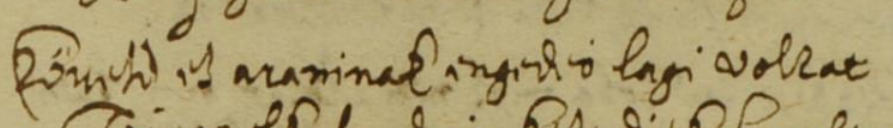

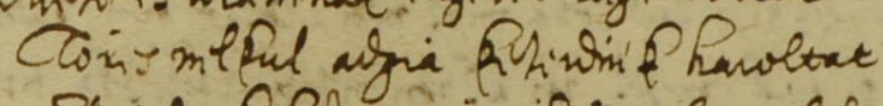

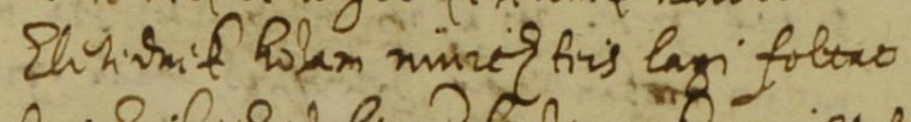

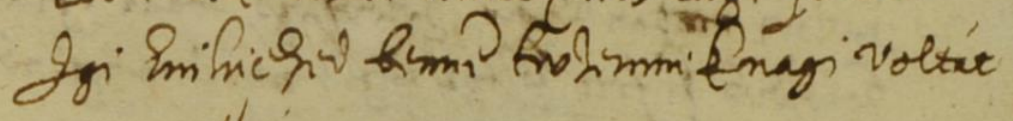

Chas.

$$
\begin{aligned}
& \text { Olyminsmm Larm inting fuma }
\end{aligned}
$$

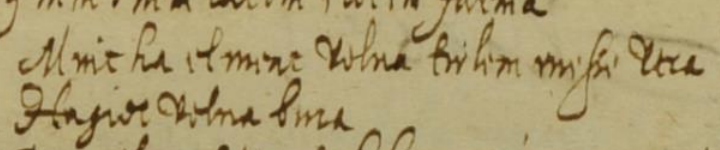

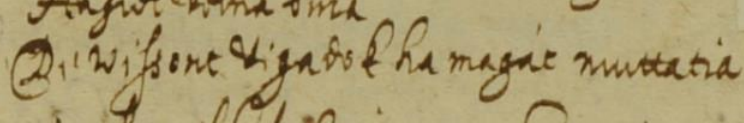

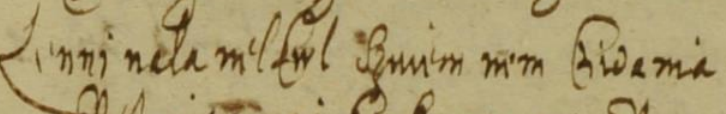
Qh. mis

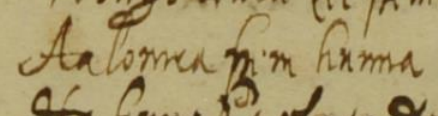

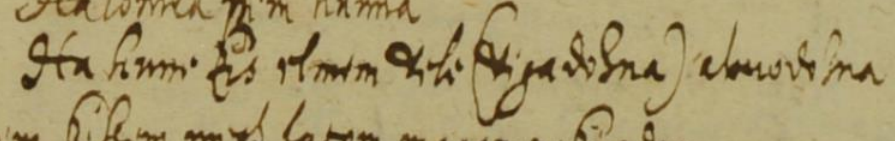

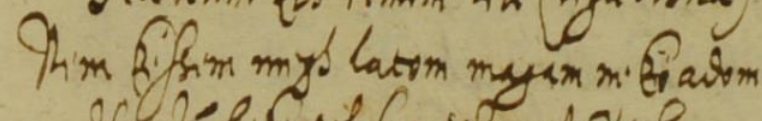

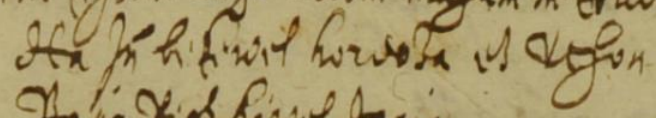
In in kigs finieganion

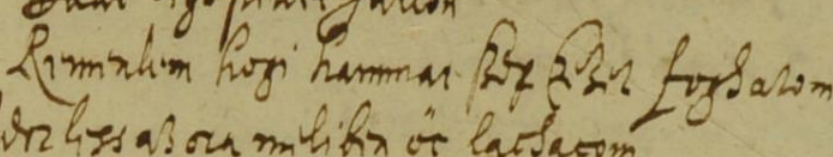
trimpintmint mifryelsacom Angs Sorgat talsatim

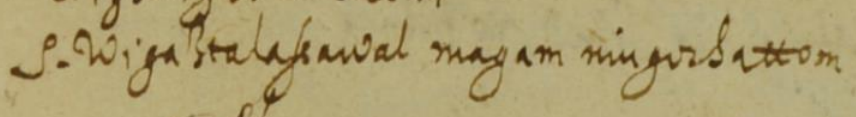
clans

tongte 


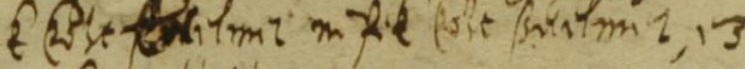
grifen fing in 7 i.

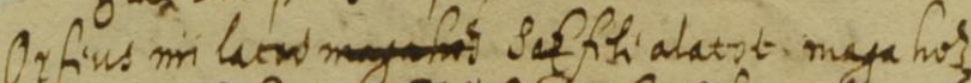

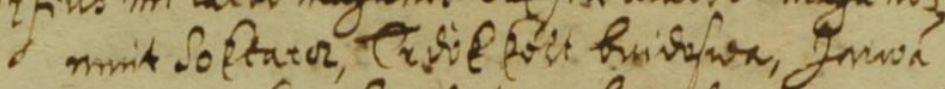

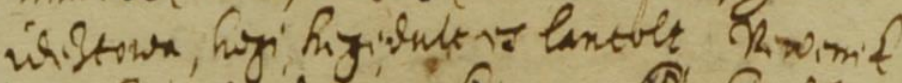

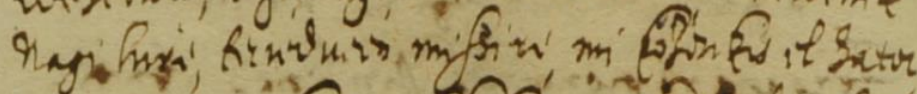

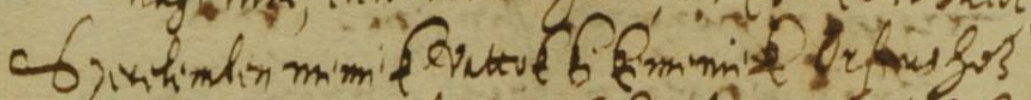

alliatif, As rula nox So for fum vav alacos

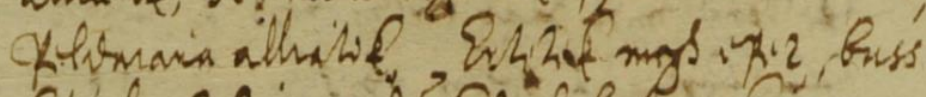

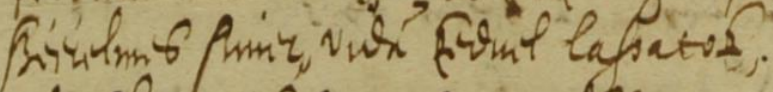

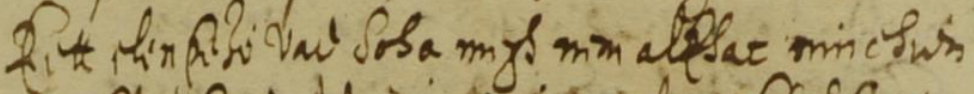

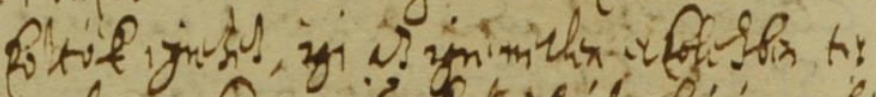

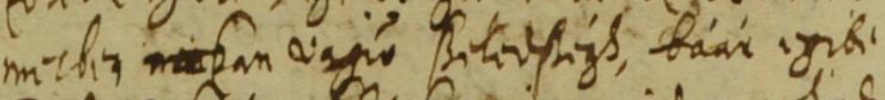

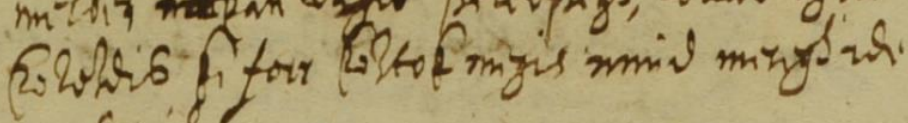
ginfring

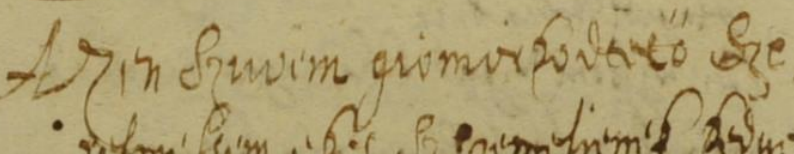 - भitmisim a

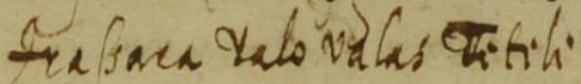<smiles>[125IH]</smiles>

ismt fivframiét

$\checkmark$ fimimimi qultsarial

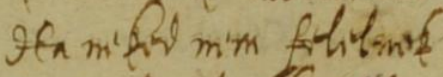

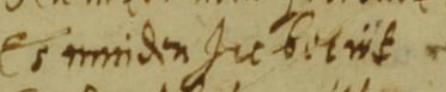

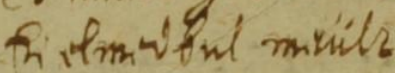

If is fint min vitant

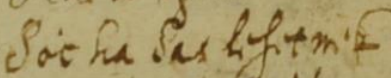
S.moisd in onllsuen' singure formo wopitmit? 


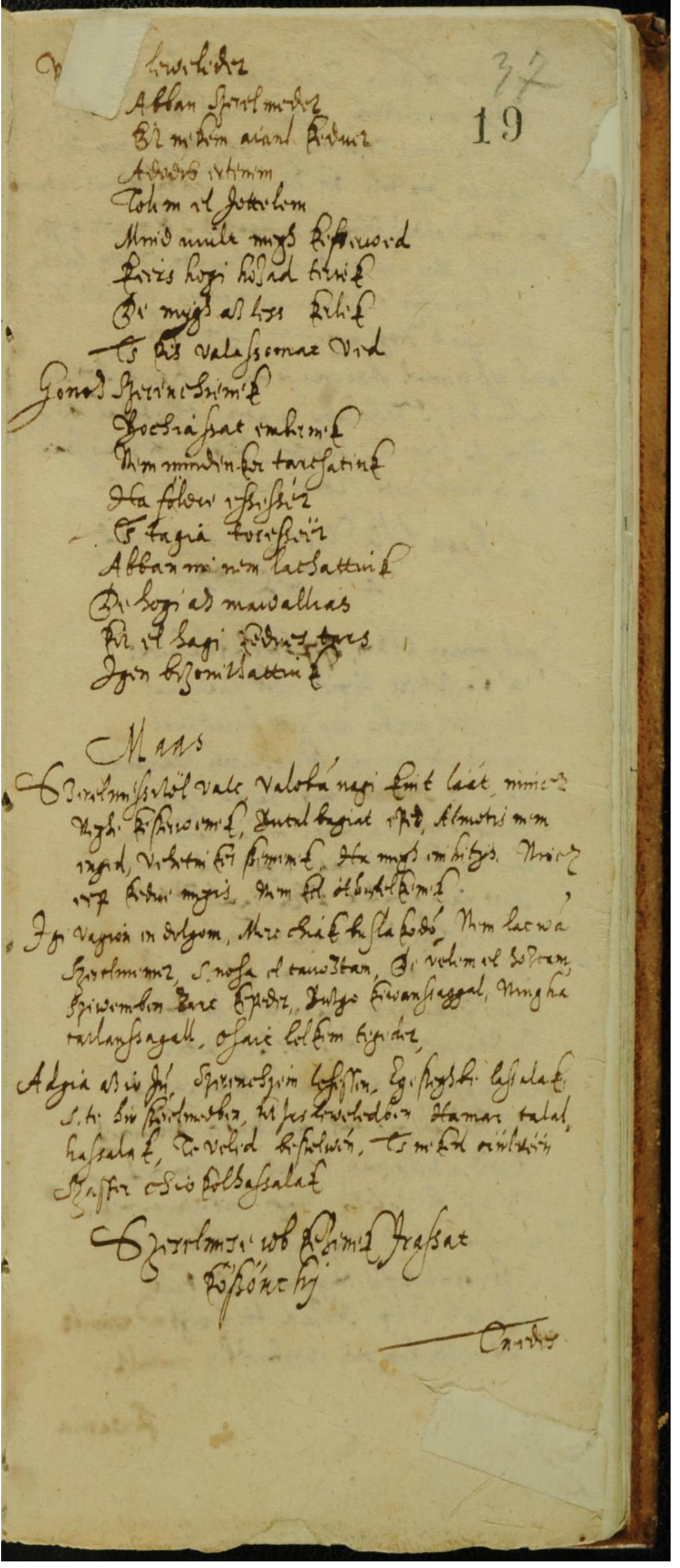




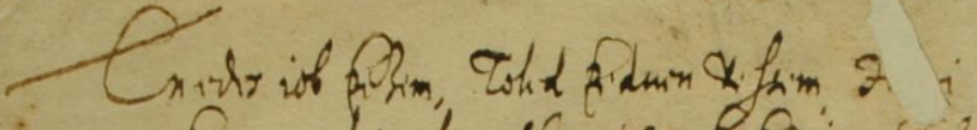

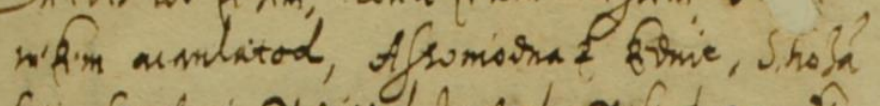

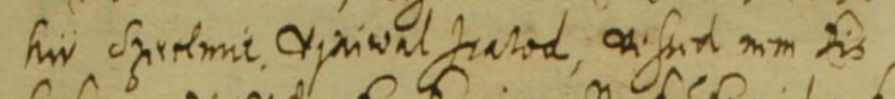

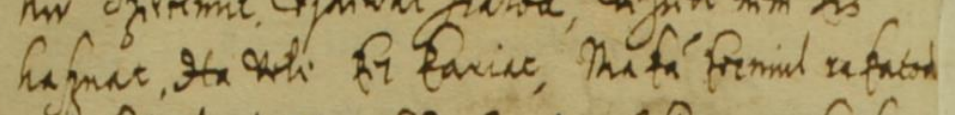

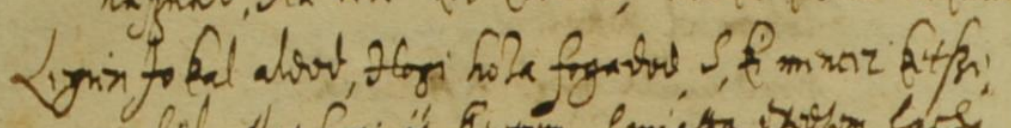

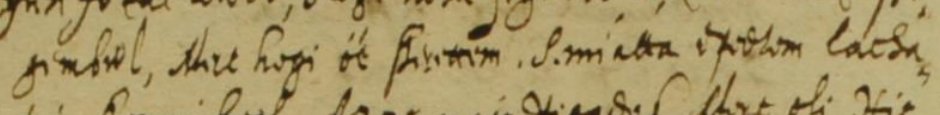

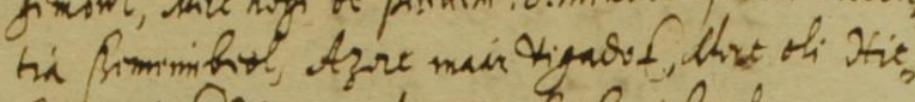

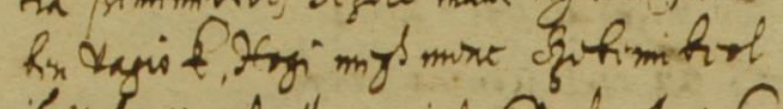

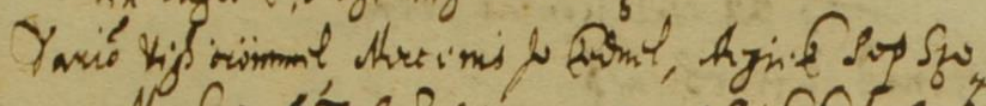

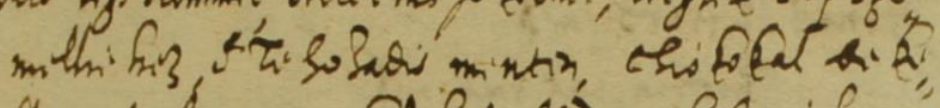

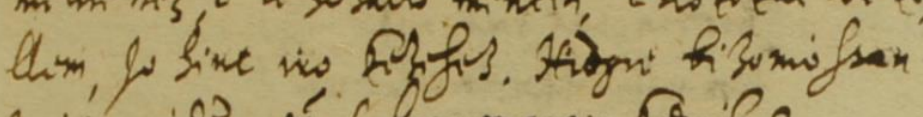

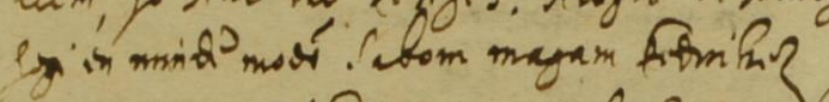
Chana hiforigarsalasannes 4 Cmigis

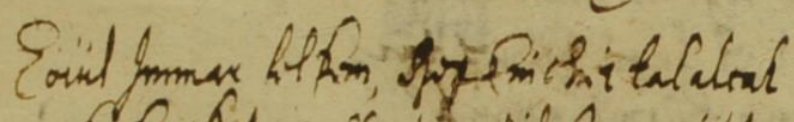

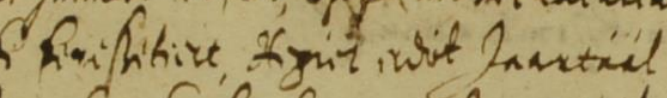

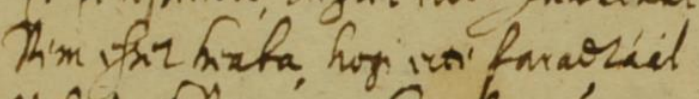

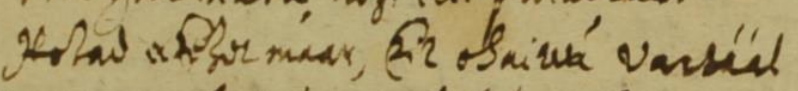

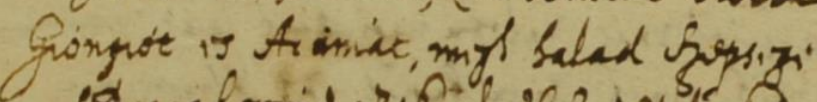

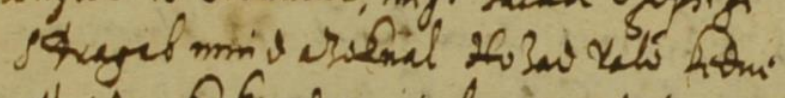

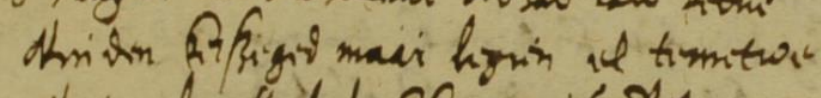

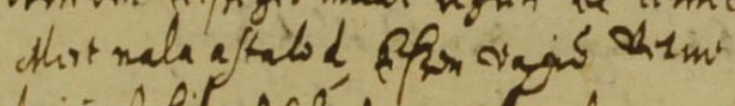

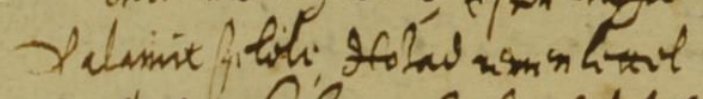

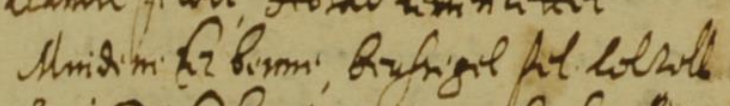

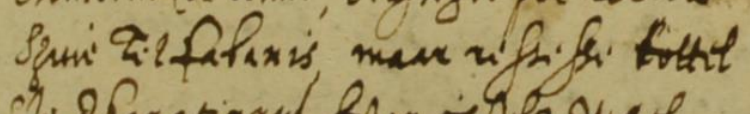

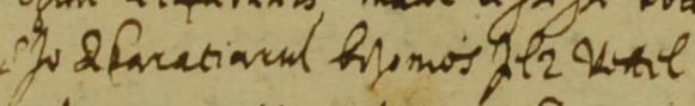

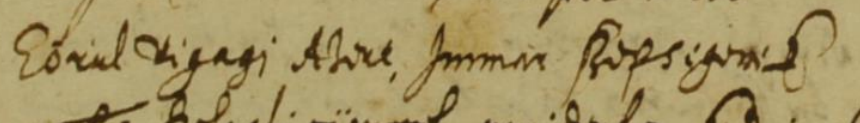

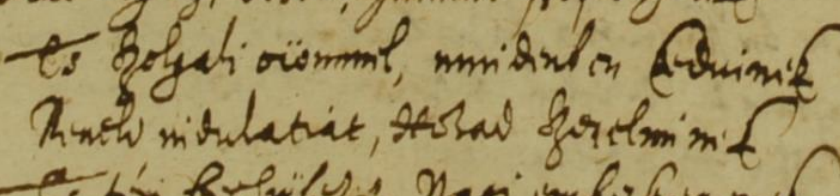

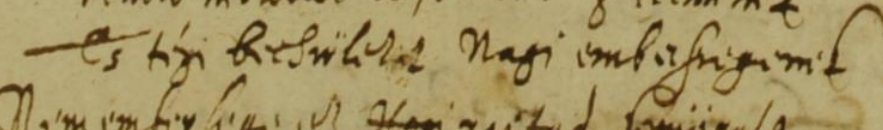

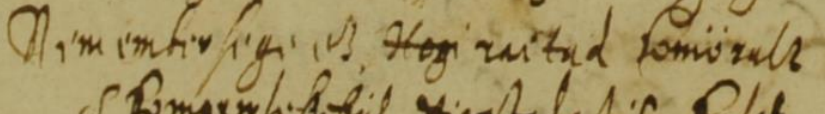

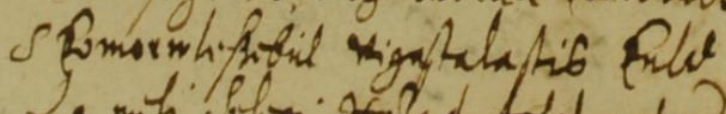

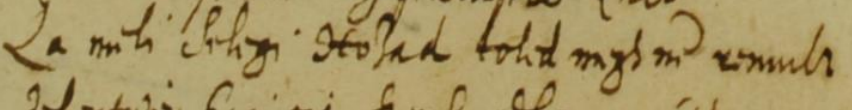

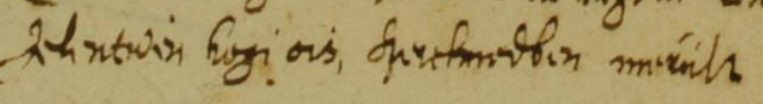

Rivama 
Q.f ur folloger bonat his in 21 cipmovion 20.m.

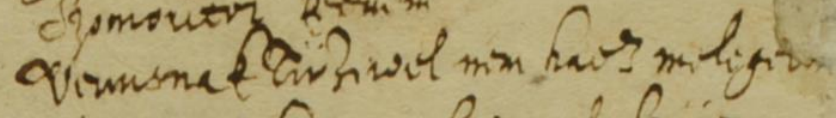

2 gighon anmat vear borogntaface.

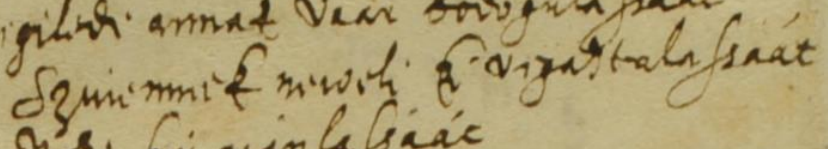
Ohs sivi ainlaficác

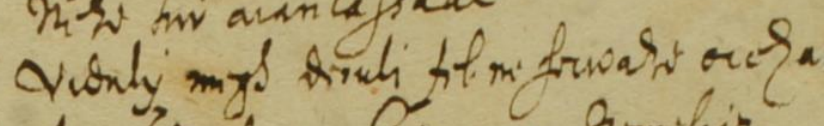

As lutro srultim Givanexm oformitir

esm ixyt hinm fiwim womatrigris

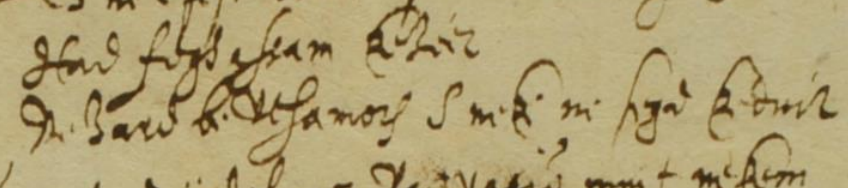

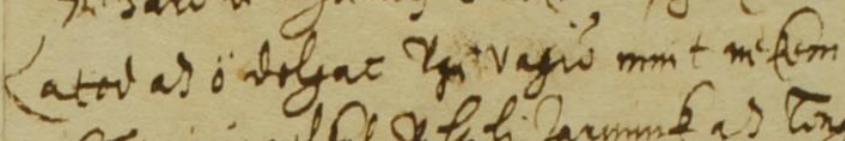

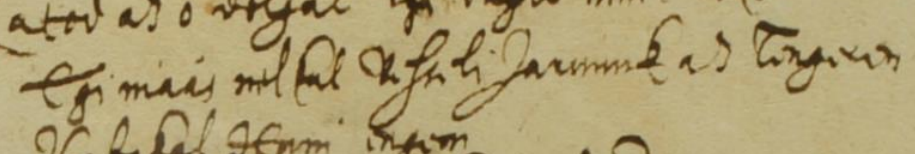

Ofubifal ofmm ingm

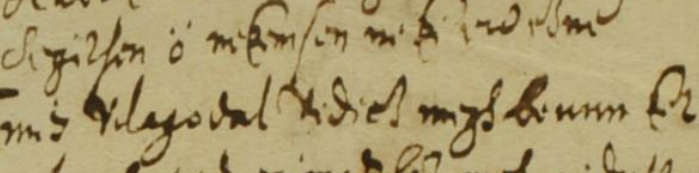

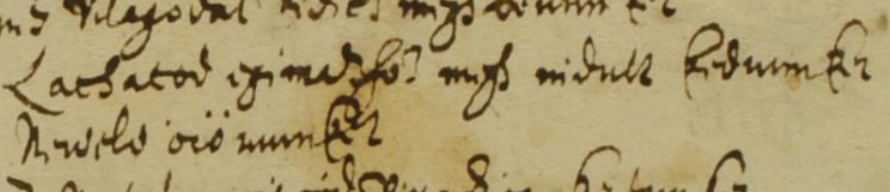

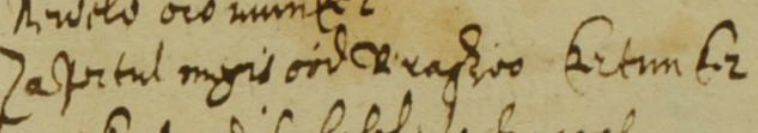

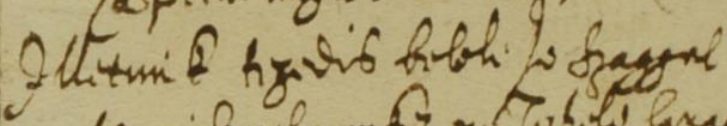

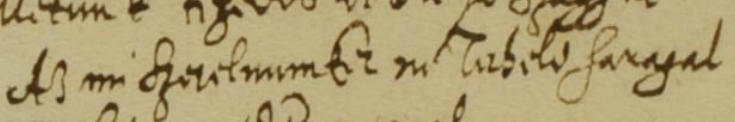

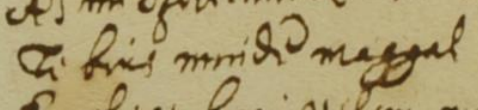

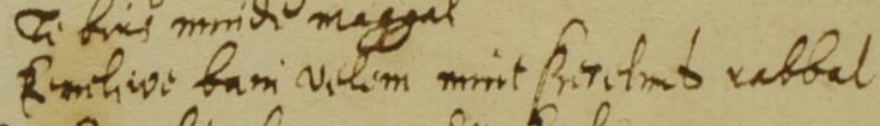

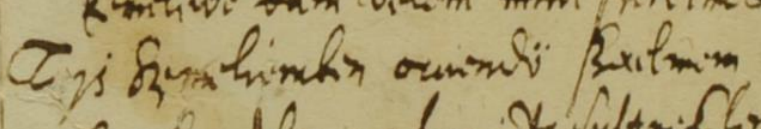

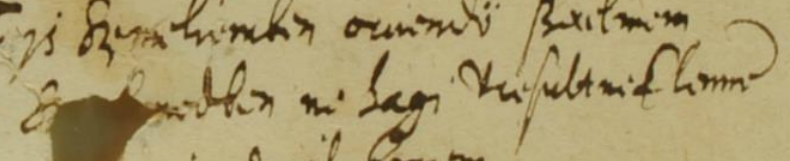

os minisinil firmm.

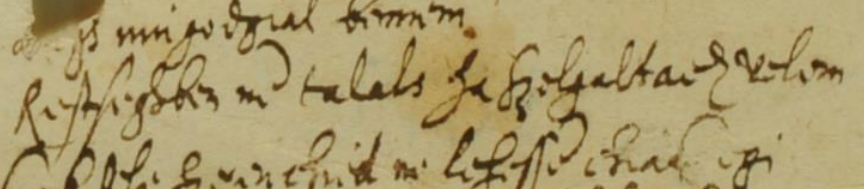
Gofph fovernd lefp in gi

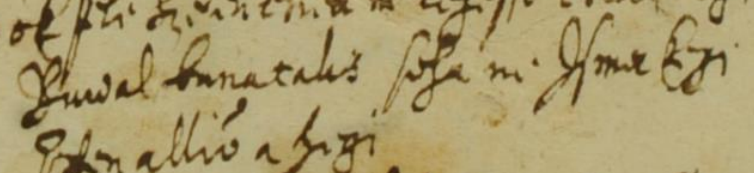
Exratió a ky

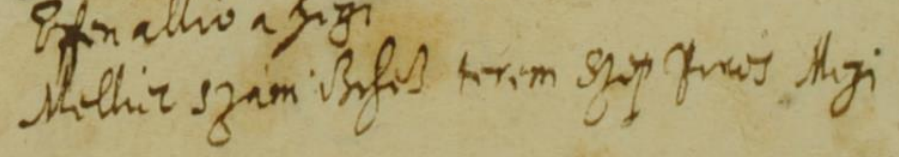




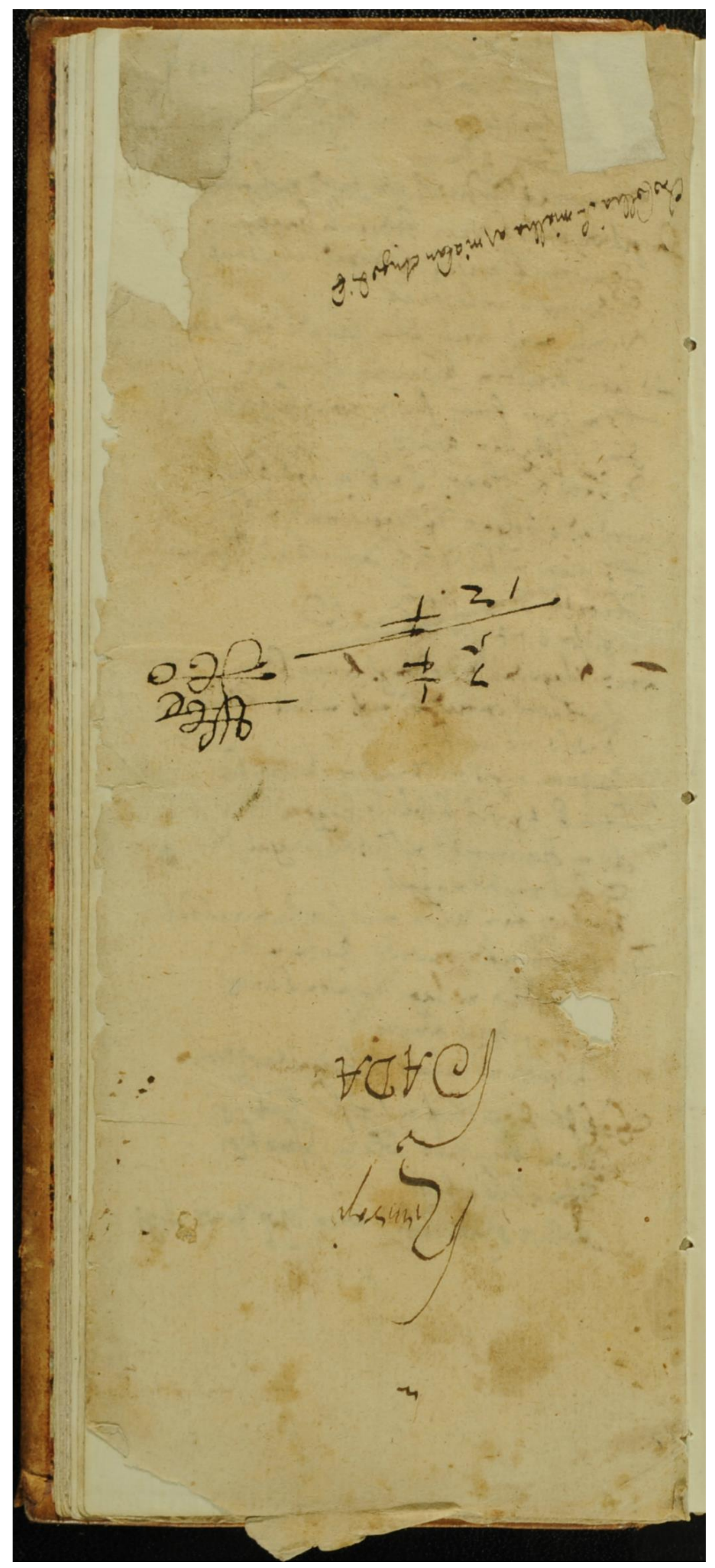




\section{A szövegközlésről}

Dolgozatomban a régi magyar szövegemlékek részleteit lehetőség szerint a kritikai kiadásuk alapján közöltem, ugyanakkor - Stoll Béla iránymutatását követve - valamennyit modern helyesírás szerint. ${ }^{50}$ Vagyis ha az adott forrás szövegét a vonatkozó kritikai kiadás előzőleg modernizálta, akkor azt változatlanul átemeltem, amennyiben viszont betühíven rögzítette, akkor a saját modern átiratomban adtam közre. Kivételt képeznek ez alól Balassi Bálint és Rimay János írásai; mert ugyan az Eckhardt szerkesztette tudományos edíciókat ezek esetében is meghivatkoztam (már csak a filológiai jegyzetapparátusok miatt is), ám az előbbieket a Kőszeghy Péter, az utóbbiakat az Ács Pál gondozásában megjelent naprakészebb kiadványok nyomán idéztem. A Balassi-versek sorszámozásában a Balassa-kódexet követtem. Ha a fentiektől valamilyen oknál fogva mégis eltértem, az minden esetben jeleztem. A szentírási lokuszokat a Szent István Társulat legutóbbi bibliakiadásából citáltam.

50 „A mai helyesírásra átírt kritikai szövegnek [...] nemcsak az az elönye, hogy olvashatóbb, hanem az is, hogy a szövegértelmezés egy része magával az átírással megvalósitható.” STOLL Béla, Szövegkritikai problémák a magyar irodalomban, Bp., Tankönyvkiadó, 1987, 40-41. 
TÜZETES RÉSZ 


\section{Ne gondold, szerelmem, könnyü indulatnak...}

Az ének izorímes, metruma négysoros felező tizenkettes. ${ }^{51}$ Terjedelme kilenc strófa, ezzel a ránk maradt verscsoport leghosszabb eleme. Ha hordozója csonkult is, a szöveg maga vélhetőleg nem, legfeljebb a cím, az argumentum vagy egyéb paratextus veszhetett el belőle (ha tartozott hozzá egyáltalán). Mindamellett könnyen meglehet, hogy a valamikor teljesebb füzetnek nem ez a vers volt a nyitó darabja.

Ha tehát a szöveget teljesnek tekintjük, annak bevezető strófája úgy értékelhető, mint ami elsősorban a figyelem felkeltésére törekszik (attentio), s ezt föként a praeparatio alakzatával kívánja elérni.

1. Ne gondold, szerelmem, könnyü indulatnak, Hogy én két szemeim csak téged vigyáznak, És szü keservivel sírással is asznak, Ha késén és ritkán jelen lenni látnak.

A teljesség feltételezését valószínüsíti, hogy Rimay János a Balassa-kódexben másodikként megőrződött szerelmes versét (Ne csudáld szivemet ...) ugyanezzel a figurával kezdi: ${ }^{52}$

Ne csudáld szivemet, hogy illyen keserves...

A tárgyalt versben azonban a praeparatio alkalmazása - túl a figyelemfelkeltés szándékán egyben egy követendő érvelési stratégia meghatározására irányul. A beszélő úgy találja, hogy a szerelem érzékekkel felfogható jelei önmagában nem bizonyítják érzései valódiságát; a sírás mint signum és a művészeten kívüli argumentumok helyett ezért a következőkben a mủvésziekre teszi a hangsúlyt. ${ }^{53}$

2. Ábrázatod mert szép és erkölcsöd szelid, Minden játékokhoz alkók esztendeid, Nekem azért hozzád szerelmem nem rövid, Kit bennem naponkint minden része többit.

\footnotetext{
${ }^{51}$ A vers kritikai kiadása: RMKT XVII/12, 43. sz.

${ }^{52}$ Mindez azért is érdekes, mert Bóta (egyéb megfontolásokból) e vers és a tizenötök kapcsán további hasonlóságokra figyelmeztet, vö. BóTA, i. m. 11, 21.

${ }^{53}$ A motívum megfigyelhető az Eurialus és Lucretia históriájában is, Eurialus levelének alábbi (220-223) soraiban: „Tudom, temagad is gyakorta jól láttad az én ábrázatomat, / Netalán szántál is, látván szemeimből sok könnyhullatásimat, / Kérlek, vedd jó néven, ha megnyitom néked most az én titkaimat." Eurialus és Lucretia históriája = Régi Magyar Költők Tára, IX: XVI. századbeli magyar költök müvei, 1567-1577, szerk. VARJAS Béla, Bp. Akadémiai, 1990 [a továbbiakban: RMKT 9], 413. (Secunda pars, 3. vsz.)
} 
A második strófa tehát a személyi érveké, mint a szép ábrázat (habitus corporis), a szelíd erkölcs (animi natura) és a „minden játékokhoz” illő életkor (aetas). Utóbbi kifejezés gyaníthatóan abban a jelentésében értendő, melyet Balassi Bálint az ő Porcogós Annókáján kér számon: ${ }^{54}$

Friss szép fejér póka, édes szürö móka,

Porcogós Annóka, szerelemnek oka,

Mit haragszol? Hogy nem játszol vélem, kivel egy fráj szól?

Látd-é, víg, ki-ki táncol!

A Hannuska Budowskionkának címzett vers egyfelől tehát rávilágít, hogy a játék szó a tárgyalt énekben is a nemi aktus metaforája, másfelől (éppen a testiség ábrázolásában) éles kontrasztot képez vele. Feltünő ugyanis, hogy szemben a fenti Balassi-verssel a Ne gondold, szerelmem... erotikuma roppant visszafogott. Bár a rövidség és a világosság általában retorikai erényeként tételeződnek, a személyi érvek ilyesfajta tömör és díszítetlen enumerációja ehelyütt érezhetően a bókolás rovására megy.

A szerelmes az invokáltról mindösszesen annyit közöl, hogy nem csúnya, nem is kikapós, hozzá pedig jól fejlett. Mindazonáltal a versben a test alig jelenik meg, s ha mégis, említése a figuratív ábrázolás közhelyes, stilizálásra kiválóan alkalmas szervekre ill. testrészekre korlátozódik, mint a szem vagy a szív.

3. Képe szemeidnek ólálkodó töre,

Nem szabadulhat ki én szivem belöle,

Ne légy hát elvadult, lelkem, te is töle,

Söt magadhoz jót vélj mindenkor felöle.

Közhelyes fordulat az is, hogy a szöveg a szemet mint veszélyforrást jeleníti meg. Jelesül tőrként, amire szintén lehet példát találni Balassi költészetében, az Ötvenharmadikban.

4. Miképpen Mars csillag jó vitéz, jó hadnagy, fegyverével mindent gyöz,

Úgy két szép szemével, mint két éles tőrrrel, Julia gyöz, megkötöz;

Nincs oly jeles vitéz, valaki reá néz, kit meg nem bír s tömlöcöz.

A tőr szó Balassi költői nyelvében (ahogy a korban általában) fele-fele arányban jelent szúrófegyvert illetve csapdát. Ehelyütt - ahogy azt jelzője és a metonimikusan értett kép (tkp. 'kopja ${ }^{55}$ ) egyértelmüsíti - az előbbi értelemben szerepel. Júlia szeme azért hasonlít a tőrre, mert azzal le tudja bírni szerelmesét, hogy aztán foglyul ejtse öt. Ebben a megközelítésben a

\footnotetext{
${ }^{54}$ Vö. a Balassi-szótár vonatkozó címszavával. JAKAB László, BöLCSKEI András, Balassi-szótár, Debrecen, DE BTK Magyar Nyelvtudományi Tanszéke, 2000 (Számítógépes Nyelvtörténeti Adattár, 8), 204.

${ }^{55}$ A kép kifejezésnek Varga Imre vélelmezi ebbéli jelentését a kritikai kiadás jegyzeteiben. (Vö. RMKT $\mathrm{XVII} / 12,733$.
} 
tőr - ahogy a Balassi által a szemre használt további metaforák (ij, tüz, fegyver) általában kiválóan illeszkedik a platonista hagyományban kiérlelt látáselméleti koncepcióba. ${ }^{56}$ Nincs ez másként Rimay Szólitván nevemen ... kezdetű énekében sem. ${ }^{57}$

8. Szeme hatalmával, ékes, szép voltával ő magáévá tészen, Felejthetetlenül szivedbe ö beül, s elmédbe zárva lészen, Csak ötet óhajtod, mert szived is csak ott minden örömet vészen.

9. Nézd meg csak két szemét, mely bév szikrákot vét, méltó gyuladozásra, De mihelt betegit, megint gyógyít, segit, hord vizet oltásodra, Hogy szintén el ne fogyj, de neki kedvet hordj, kész ö megtartásodra.

Csakhogy a szem a tárgyalt versben bocsát ki semmit (mint Júliáé), hanem éppen ellenkezőleg: elnyel. Nem hatol a szívbe (mint Lídiáé), hanem magába zárja azt. A kép tehát azért lesz érdekes, mert ellentmond a látás extramissziós modelljének. Vagy nem ismeri ezt a toposzt, vagy kerüli használatát.

Grammatikailag nem egyértelmü, kire vonatkozik a strófában a lelkem megszólítás. Elvileg egyként értékelhető invokációként ill. aposztrophéként. Az adott (jóllehet, fiktív) retorikai szituációban ez utóbbi nagy bizonyossággal kizárható. Diszpozícióját tekintve az ének gondosan felépített udvarló versként hat. Ebben a verstípusban a szónoki szándék természetszerüleg suasio formájában artikulálódik. Az azonban elég valószínütlen, hogy a szerelmes eddigi megszólítottjától elfordulva e ponton hirtelen önmagát kezdené győzködni, avagy saját kétségeit igyekezne eloszlatni. A rábeszélés eszközeként az obsecratio is vélhetőleg a másik félre irányul: azért esedezik hozzá, hogy ha már egyszer rabul ejtette tekintetével, legalább fogadja el közeledését.

4. Ha peniglen vétek s ártok szerelmemmel, Nem tusakodhatom, meghidd, ez vétkemmel, Vétenem ellened igy mind holtomig kell, Mert édes képedet nem felejthetem el.

E ponton a genus deliberativum, mint az adott verstípus által meghatározott beszédnem a genus iudiciale körébe tartozó sémákkal keveredik. ${ }^{58}$ A szerelmes az igazát keresi: ha a

\footnotetext{
${ }^{56}$ A folyamatot Jankovits László egy nemrégiben megjelent tanulmányában így foglalta össze: „,[A] nappali fény és a szemböl kiáradó fény egyazon szelíd, nem égetö tüzből van: a szemböl az elme indíttatására kiáradó intenzív fény sugarának hatására a környezet tárgyai ugyanilyen fényt sugároznak $k i$, s a látható világ az így keletkezett testekben mutatkozik meg. ”J JANKOVITS László, Rimay János: Örülhetne szivem ..., ItK, 2011, 253.

${ }^{57}$ Uo., ill. BALÁzs-HaJdu Péter, JANKovits László, PAP Balázs, Apró madár hálóban? A Balassa-kódex első Rimay-verséröl = Septempunctata: Tanulmányok Petröczi Éva hatvanadik születésnapjára, szerk. PÉNZES Tiborc Szabolcs, Bp., rec.iti, 2011, 29.
} 
szerelme szükségszerüen bünös is, ő maga voltaképpen áldozat az ügyben. $\mathrm{Az}$ argumentációban ennek megfelelően mind nagyobb szerepet kapnak az okból vett érvek.

A lélektani okok az udvarló verseknek általában sajátjai. Ezek egyrészt a jó elérését célozzák: a beszélő szerelembe esett (adeptio, 1. vsz.), mely egyre csak fokozódik (incrementum, 2. vsz.), múlhatatlan (conservatio, 3-4 vsz.) és immáron hasznát is szeretné venni (usus, 5. vsz.).

5. Ez vétkemtül ugyan nem óhadd magadat, Azért ez vétkemet szabadságában hadd, Én édes szép sólymom, te se légy hozzám vad, Kezemnek két szárnyad simogatnia hadd.

Ezzel egyidejüleg azonban ügyelnie kell a rossz elkerülésére is, de mivel azt kikerülnie (evitatio, 3-4. vsz.) rajta kívül álló okokból nem lehet - elviselni (tolerantia, 7-8. vsz.) is alig bírja -, ezért szükségképpen enyhülésért (imminitio) ill. szabadulásért (liberatio) esedezik.

6. Magad és szemeid oka szerelmednek,

Kikkel az ragyagó csillagok sem érnek,

Fészke egyedül vagy minden gyötrelmemnek,

Töled is kell kérnem enyhitést tüzemnek.

Fentebb úgy látszott, a vers szerzője Balassitól és Rimaytól egyként különbözően törekszik ábrázolni szerelmese szemeit, tekintetét és általában a látás mechanizmusát. A fenti hasonlat okán azonban - mely láthatóan azért mégiscsak számot vet azzal - vissza kell térnünk a kérdésre.

Már a verset érdemben elsőként elemző Nagy Ferencnek is föltünt, hogy a beszélő a szerelmi költészet közhelyes trópusainak egész arzenálját mozgósítja. ${ }^{59}$ Mi tagadás, a szempár mint tőr (9. sor), a csapdába esett szív (10. sor), a szerető, mint engedelmes sólyom (19-20. sorok), a szerelem, mint a gyötrelem fészke (23. sor), vagy mint a tüz, ami enyhítésre vár (24. sor), a szerelem okozta sebek (26. sor), a szerető, mint orvosság (31. sor), a szerelmes, mint rab (36. sor); valamint az elmaradhatatlan hiperbolikus fordulatok: az örökké a kedvest kutató szempár (2. sor), a legyőzhetetlen vétek (14-15. sorok), a csillagoknál is ragyogóbb szemek (21-22. sorok), a megezerszerezett napok (33. sor) képei valóban nem tünnek túlságosan invenciózusnak. Ez azonban önmagában feltétlenül nem negatívum, hiszen a szerelmi

\footnotetext{
${ }^{58}$ Ennek lehetőségét a korabeli retorikai irodalom is megengedi. Vö. Philipp MelanchthON, A retorika alapelemeinek két könyve $=$ Retorikák a reformáció korából, szerk. IMRE Mihály, Debrecen, Kossuth, 2000 (Csokonai Universitas Könyvtár: Források - Régi Kortársaink, 5), 57.

${ }^{59} \mathrm{NAGY}$, i. m., 4.
} 
költészet nyelve erősen kodifikált, ennek megfelelően jelölői, ha nem valamely koherens rendszer tagjaiként artikulálódnak, könnyen megkopnak.

A tárgyalt vers képhasználatára azonban ez a koherencia csak kevéssé jellemző. Azt lehet ezért mondani, hogy Ne gondold, szerelmem... poétikai gyakorlata a közköltészetivel rokon: szerzője a toposzok puszta felmutatásától reméli a kívánt hatást elérni. Ellenpéldaként az az elocutio szempontjából figyelemreméltó teljesítmény kínálkozik, mely az invokáltat egyszer sólyomként, másszor meg fészekként láttatja. (Annál inkább tünik katakretikusnak azután a fészektől remélni a tüzoltást $\left.{ }^{60}\right)$. Csakhogy ez sem önálló lelemény, hanem szimpla Balassi-reminiszcencia (vö. Ötvenhetedik, 10-11. ill. 16-17. sorok):

Szép sólymok, vad rárók, kiket madarászok tanitanak, viselnek,

Bánással, tartással, szóval, kiáltással, szelídek, kézre jünek...

$[\ldots]$

Téged penig, sólymom, én édes vad ráróm, az én sok kiáltó szóm Kezemre nem hihat...

Illetve ugyanott (28. sor):

Úristen, hogy lehet az kegyetlenségnek ilyen nagy szépség fészke?

Ahogy a tárgyalt ének néhány további motívuma ill. trópusa (a szerelemtől égő szív; a szerelem, mint rabság; a síró szerelmes) is megtalálható az Ötvenhetedikben (32-33. sorok):

Képtelen nagy szépség, ki miatt szivem ég, mert már elrekkentette Buzgó szerelmében, kiben, mint tömlöcben, sírva ezt éneklette.

Az viszont, amit a szerelmes vétkei okaként állít (az édes kép és a ragyogó szemek), valójában a habitus corporis ténylegesen bókoló érveinek bizonyulnak. Balassi latrikánus versének argumentációja ezzel szintén több párhuzamosságot mutat - nem véletlenül, hiszen célja annak is a rábeszélés -, ugyanakkor lényegre törőbb. Abban is a megszólított a szerelem oka, de jelentsen bármit a pulyka fehérsége és a mókusszőr édessége, azoknál a sólyom szárnya mégiscsak kevésbé frivol jelentéstartományt konnotál. A lélektani okok teljes felsorakoztatására Balassinak sincs szüksége; latrikánus versről lévén szó, a cél pusztán a kurtizán megnyerése és használata - vagyis táncba vinni Annókát. Ehhez hasonló motívum a Ne gondold, szerelmem... esetében az ugratásé - mert a Balassa János éneke

\footnotetext{
${ }^{60}$ Ugyancsak Nagy Ferenc szubtilis megfigyelése. Uo., 11.
} 
tőszomszédságában amennyire disztingváltnak tünik a sólyomszárny simogatása, annyira nem az a szökkenés.

7. Jövell hát, szépségem, ugorgyál elömben,

S lássad, nem vagyok-e sebhült szerelmemben,

Épits és újits meg elbágyadt kedvemben,

Tartsad meg lelkemet, mely legyen keblemben.

Hogy ennek mégsem kell feltétlenül illetlen dolgot jelentenie, azt Rimay már az extramisszió kapcsán idézett verse is bizonyítja. Abban Vénusz istenasszony a következőképpen laudálja Lídiát:

12. Ládd, hogy egyedül ö, kihez minden illö, beszéd, tréfa, éneklés, Tánc, járás, ugrálás, nézés, vég mosolygás, módjával való lépés, Hivi, buzgó szerelem, s bódog, kinek ebben lehet részesültetés.

Tánc és játék Balassinál kirajzolódó szinonímiájával szemben e versben a kérdéses kifejezések a halmozás alakzata köré szerveződnek. És bár teljes biztonsággal nem is lehet definiálni, mit jelent benne az ugrálás, annyi bizonyos, hogy nem azt állítja, hogy a nevezett hölgy alkó valamire, hanem hogy bizonyos (udvarias) tevékenységek illők őhozzá. ${ }^{61}$

Bóta László sokat idézett tanulmányában gondosan emendálja a tárgyalt verset, mintegy érvként arra a megállapítására, hogy annak Madách csupán avatatlan másolója volt, és semmi esetre sem szerzője. Sok egyéb mellett érvként hozza a 29. sor ragozatlan igenévi alakját (látó), melyet inkább Rimay, mint Madách költői nyelvére jellemzőnek. ${ }^{62}$

8. Immár ezt most neked látó bizonyságul,

Mind magamnak tartlak téged nyájasságul,

Lelkemnek hát magad adjad orvosságul,

S fájdalma azonnal mindenestül tágul.

\footnotetext{
${ }^{61}$ Egy szegedi keddeste alkalmával Molnár Dávid kitartóan érvelt amellett, hogy a tizenöt szerelmes vers szerzője mégiscsak maga Rimay János lett volna. Egyik érve az volt, hogy az alkó kifejezés megjelenik Rimay Náprági Demeternek írott levelében is. (A levél kritikai kiadását ld.: RÖM, 233-235.) E megfigyelést továbbra sem tartom perdöntőnek. A szóalak ritkán adatolható, de nem hapax; 'megfelelö, alkalmas' jelentésben előfordul már a Szabács viadalának 101. sorában is: „Honnég alkóbb Sabácot veretni”. Ez alapján Imre Samu 'megfelelö, alkalmas' jelentésben magyarázza. (Vö. IMRE Samu, A Szabács viadala, Bp., Akadémiai, 1958 (Nyelvészeti Tanulmányok, 4), 20, 99.) Versszövegbe illeszteni pedig nem csupán keresettsége, de metrikai odaillése miatt is indokolt lehet. A Náprági-levél mindössze annyit bizonyít, hogy Rimay használta a szót környezetében sem lehetett ismeretlen, ill. az is átvehette töle. Ide tartozik még, hogy Rimay szerzőségét Eckhardt többek között éppen a tárgyalt vers 5. strófáját kiemelve cáfolja, mondván, hogy ahogy Balassi, úgy Rimay is következetesen a kötőhang régiesebb formájával használja a tárgyragot ('-at' helyett '-ot' alakban). Vö. RÖM, 164, ill. a bevezetö fejezet (A tok és a látcső) 26. lábjegyzete.

${ }^{62}$ BÓTA, i. m., 20.
} 
A „látó bizonyság” szintagmát azonban nem értelmezi. Továbbá elsiklik afölött, hogy a fenti verssor mint tagmondat ebben a formájában elliptikus, hiszen hiányzik belőle az állítmány, s e hiányt a strófa további sorai sem pótolják.

Épp Bóta dolgozatának ismeretében merül fel a gyanú, hogy a fenti anacoluthon szövegromlás eredménye. Azt persze lehetetlen megmondani, pontosan mi változhatott, mindenesetre ha a ,, látó bizonyság” látható bizonyítékot jelent, az argumentációból azonban a müvészeten kívüliek kizárattak, feltehetjük, hogy a deiktikus utalás magára a szövegre irányul. ${ }^{63}$ A tárgyalt versnek több mozzanatában mintául kínálkozó Ötvenhetedikben Balassi ekként panaszkodik (3. sor):

Sok könyörgésemre, szép leveleimre csak választ sem téssz nékem?

A Ne gondold, szerelmem... viszont a fentiek fényében maga kívánja a szép levél funkcióját betölteni. Ezt végül aztán a záró strófa teszi egyértelművé.

9. Ezer napja legyen életed egy napja,

Jó szerencséd legyen te ügyednek apja,

Vig kedvedet penig kezivel az kapja,

Ki szerelmednek lött megköttetett rabja.

Bóta nyelvi párhuzamosságként említi a 35. sorhoz Rimay Kerekded ez világ... kezdetü versének első strófáját: ${ }^{64}$

1. Kerekdéd ez világ, gömbölyü, mint lapta,

Ritkán vált, ki ötet kezével jól kapta,

$S$ véle keblét rakta,

És kedvelt javait vidám szívvel lakta.

A fenti szintagmán kívül Bóta további formai érve a tizenötök attribúciójának kérdésében az egy szótagos rímeken alapszik. ${ }^{65}$ A rímelés keresettsége a legutóbbi időkig fontos érv lehet

\footnotetext{
${ }^{63}$ Legprimitívebb magyarázatnak tehát az egyszerủ betűcsere (immár írám) kínálkozik.

${ }^{64}$ Uo., 12. Bóta egyébként nem is ezt a párhuzamosságot tartja a legjellemzöbbnek: ,a $M-R$ kódexek szerelmes versei (különösen a Radvánszkynál a 11 és 16-25 szám alatt közökt énekek) épitettségük tekintetében elütnek Rimaynak a Balassa-kódexböl ismert erösen retorikus izü szerelmes verseitöl, kivéve a »Ne csudáld szivemet" kezdetü, mindössze 18 soros kis éneket, no meg az »Örülhetne szivem « kezdetüt, amelyekhez viszont igen erös hasonlóságot mutatnak. [...] A szerkesztés és a hangvétel közvetlensége arra mutat, hogy ezek a versek afféle szerelmes leveleknek, üdvözletnek készültek; ebböl a funkciójukból magyarázható tömörségük, meghitt, bensöséges líraiságuk." (Bóta, i. m., 21.) Ebbe a képbe valóban nem illeszkedik a Nagy példát adhatok..., a Kiki terhét vállán... és a Szerelemtül csak kár... kezdetủ ének, lévén az előző kettő moralizáló, az utóbbi pedig latrikánus. Annál nehezebb megmondani, miért marad ki a felsorolásból a Bírja bár akárki... kezdetủ vers, ld. a vonatkozó fejezetet.

${ }^{65}$ Uo., 22.
} 
Rimay szerzősége mellett, ${ }^{66}$ mindazonáltal a nap-kap-rab rímszavak közül Balassi csenget össze kettőt:

Ó, szerencsétlen nap, ki elragad és kap attól, ki hiven kedvelt!

Annál is valószínűbb, hogy a rímpár az Azmely keresztyén hü... kezdetü vers ismeretét tükrözi, hiszen e gyüjtemény tizenkettedik darabja (Szerelmesitöl vált...) annak egy egész strófáját applikálja. ${ }^{67}$ Csakhogy az utolsó strófa esetében igazán releváns mintának egy Balassi ill. Rimay szerelmi lírájánál mindenesetre - sokkal távolibb és sokkal indirektebb hatású szöveg bizonyul.

A magyar irodalom elsőként ismert szerelmes verse köztudomásúlag egy 1485-ből ránk maradt tollpróba: Török Imre verses üdvözlete Parlagi Krisztinához, amely a lány sógorához írott misszilisének záradéka. ${ }^{68}$

Emericus Terek köszön Krisztinának,

legyen kenyvebb jnhának.

Száz jó napat, két száz jó ét hozjája.

A verset a legutóbbi időkig tüzetesebben csak Horváth Iván elemezte, mint a Balassi előtti szerelmi költészet kevés emlékének egyikét. A vizsgálat arra irányult, tetten érhető-e a fin'amors ideológiája, mint az arisztokratikus regiszterbe tartozás záloga ezekben a szövegekben. Csakhogy (Horváth Iván szerint) az üdvözlövers ebböl a szempontból értékelhetetlennek bizonyult: az arisztokratikus regiszterben nem helyezhető el, hiszen a fin'amors igénye nem ragadható meg benne, de az archaikus nőszemlélet jelei sem - hacsak nem „a köszöntés férfias, eröt-egészséget jellege: mintha Török Imrének nem lettek volna szavai a nök számára". 69

Ráadásul ezt a keveset is csak kölcsönözte: Bognár Péter éppen a köszöntés típusa alapján határozza meg a vers eredetvidékét. Bognár példák sorával bizonyítja, hogy az a későközépkori német költészet szerelmi tárgyú üdvözlőverseivel mutat közeli rokonságot. Az alábbiakban egyezik azokkal: rövid, együgyü, alkalomhoz nem kötött, elküldésre szánt, prózai

\footnotetext{
${ }^{66}$ PAP Balázs, Az Istenes énekek margóira = Ghesaurus: Tanulmányok Szentmártoni Szabó Géza hatvanadik születésnapjára, szerk. Csörsz Rumen István, Bp., rec.iti, 2010, 335-342.

${ }^{67}$ Bövebb elemzését 1. ott.

${ }^{68}$ Vö. TóтH Tünde, A virágének-vita $=$ A magyar irodalom történetei, I, A kezdetektöl 1800-ig, szerk. JANKOVITS László, ORLOVSZKY Géza, Bp., Gondolat, 2007, 133-146. A vers kritikai kiadását ld.: Köszöntő 1985-böl [Emericus Török...] = Régi Magyar Költök Tára, I: Középkori költőii maradványok, szerk. SzILÁDY Áron, Bp., 1877, 199.

${ }^{69}$ HORVÁtH Iván, Balassi költészete történeti-poétikai megközelitésben, Bp., Akadémiai, 1982, 248. Kiemelés, ha másként nem jelölöm, mindig az eredetiben.
} 
levélhez illeszthető, valamint szerepel benne a sok ill. megsokszorozott időegységre szóló jókívánságok formulája. $^{70}$

Hogy a köszöntés (ellentétben Török Imre Verses üdvözletével) nem prózai levél toldalékaként, hanem a tárgyalt vershez hasonlóan strofikus vers zárlataként jelentkezik, szintén nem példa nélkül való a 15 . század német nyelvü költészetében ${ }^{71}$ - ahogyan a jelek szerint nem az a magyar 17. századi magyar költészetben sem.

Ezért Bognár kérdése, hogy ismerhette-e Török Imre a későközépkori Liebesgruss múfaji hagyományát, ${ }^{72}$ valójában aligha vár feleletre. Konszenzuálisan elfogadott megállapítás, hogy a magyar nyelvü szerelmi tárgyú költészet legkorábbi emlékei közé sorolható Körmöcbányai táncszó is német hatást tükröz. ${ }^{73}$ A kérdés másik fele pedig - az, hogy honnan ismerhette a müfajt Török - megválaszolhatatlan. A felmérhetetlen mennyiségü érintkezési pont egyrészt életszerűvé teszi a hipotézist, másrészt viszont ellehetetleníti a konkretizálást. A valódi kérdés ezért mégiscsak az, hogy a fentiek mennyiben érintik a Balassi előtti magyar nyelvü szerelmi költészetről alkotott képünket. ${ }^{74} \mathrm{~S}$ noha Bognár leszögezi, hogy erre az alapvetően formatörténeti érdekü dolgozatában nincs módja kitérni, mintegy érintőlegesen és nagyon mértéktartóan mégiscsak megteszi: „a csiszolatlanság minden formáját kerülö magyar szöveg [...] azon a skálán, amelynek két végpontját az obszcén, ill. az udvari típusú szerelmi köszöntés jelöli ki, talán ez utóbbihoz áll közelebb. ",75

Két egymástól ennyire távol eső adatból (mint a Verses üdvözlet és a Ne gondold, szerelmem...) átfogó narratívát igen elnagyoltan lehet csak létrehozni. Annyi mindenesetre bizonyos, hogy nagyon kicsi az esély arra, hogy két egy tőről fakadó, de amúgy izolált jelenség őrződött volna meg. Az egész ügy tehát összességében valamiféle évszázados hagyomány emlékét feltételezi, vagyis a kérdés nemcsak a Balassi előtti, de a Balassi utáni költészet szempontjából is fölöttébb lényegesnek mutatkozik.

\footnotetext{
${ }^{70}$ BogNÁR Péter, A régi magyar vers formatörténete a 16. század végéig, PhD-értekezés, Bp., 2012, 207-217. Megkockáztatom, hogy az utolsó elötti (35.) sor (, Vig kedvedet penig kezivel az kapja”) értelmében a beszélő kézzelfogható, vagyis írásbeli választ vár a kedvesétől; annál is inkább, mert a gyüjtemény 11., 12. és 13. darabja (tehát az Ércnél, kösziklánál..., Szerelmesitöl vált..., Én édes jobb kezem... kezdetű énekek) szintén a szerelmesek levélváltására utalnak. A sor másik lehetséges jelentése a kézfogó intézménye, ami szintén viszonylag gyakori motívum a vizsgált anyagban, vö. a 9., 11., 15. versekkel (Oly nehéz nem látnom..., Szerelmesitöl vált..., Beborult, fölhözött...). Ld. a vonatkozó fejezeteket.

${ }^{71}$ Uo., 210.

${ }^{72}$ Uo., 215.

${ }^{73}$ E kérdésröl ld. még: LuDÁNYI Mária, A „Supra aggnő” forrásvidéke” = Klaniczay-emlékkönyv, szerk. JANKOVICS József, Bp., Balassi, 1994, 136-142.

${ }^{74}$ BOGNÁR, i. m., 215-216.

${ }^{75}$ Uo., 216-217.
} 


\section{Összegzés}

A Ne gondold, szerelmem... szerzője láthatóan erősen kötődik Balassi és Rimay hiteles szerelmes verseinek szó- és képhasználatához - de nem szolgaian, még ha megoldásai némiképp kiforratlanok ill. katalógusszerüek is. Azzal együtt figyelemre méltó retorikai teljesítmény az inventio müveletében a müvészeten kívüli bizonyítékok kizárása a magát misszilisként beállító levélversböl. Sikerültnek hat, ahogyan a kifejezés (elocutio) örökül kapott eszközeinek megválogatásával - ha a bókolás rovására is, mindenesetre a „,csiszolatlanság minden formáját kerülö” módon - elhárítja a testiség alantas képzeteit. Mindamellett pedig felvonultat egy olyan formulát is, amelyre sem Balassi, sem Rimay költészetében nem találni példát, mégis - azoktól függetlenül is - alkalmas lehet a gáláns udvarlásra. Ami arra enged következtetni, hogy a 17. század első harmadában Balassi költői nyelvének imitálásával együttesen egy régebbi, de azzal egyazon regiszter felé tendáló gyakorlatból is lehetett meríteni. 


\section{Nagy példát adhatok énrólam mindennek...}

Az ének három strófából áll, metruma négysoros felező tizenkettes, izorímes. ${ }^{76}$ A versforma keresettnek aligha mondható, ám megválasztásától bizonyosan nem független, hogy (amint arra Eckhardt Sándor korai, nagy lélegzetü tanulmányában rámutat) utolsó strófája szorosan követi Balassi Bálint Hetvenharmadik c. versének (De mit gyötresz...) közhelyes zárlatát. ${ }^{77}$ Balassi ugyanis a következő sorokkal rekeszti be ezt az énekét:

9. Indulnak oly könnyen mert ök ide-s-tova, Mint szinte aszú ág szél fuallására, Böcsülik maguk közt s tartják legnagyobbra Azt, aki közülünk többet ejtett búra.

A Nagy példát adhatok... végszavaiként ezek az alábbiak szerint variálódnak:

3. Hajlók mert az rosszak minden hivságszóra, Mint aszú falevél szél fuvallására, Becsülik és tartják magok közt nagyobbra, Ki közülünk köztök többet hajtott rajta.

Bóta László úgy találja, hogy az utóbbi versszak értelmetlen, s ezt - a többi homályos értelmü hellyel egyetemben a rossz másoló Madách Gáspár számlájára írva - szövegromlással magyarázza, ${ }^{78} \mathrm{~s}$ arra a hangsúlyozott azonosság alapján a következő javítási megoldást kínálja: „Nem kétséges, hogy az utolsó sor az eredetiben így álhatott: Ki közülünk köztük többet hajtott arra, v. bura."79 Bóta alighanem jó érzékkel emendál. Az ének szerzőjének imitációs technikáját illető határozott kijelentéseket azonban csak olyan szövegeltérések figyelembevételével lehet tenni, melyek bizonyosan nem a másoló szándékolatlan (s ebben az értelemben funkciótlan) tévesztéseiböl adódnak, márpedig a fönti strófa esetében közel sem biztos, hogy a grammatikailag egyébként helyes, szemantikailag azonban csak anakronisztikus megoldásokkal védhető részlet az egyetlen ilyen.

\footnotetext{
${ }^{76}$ A vers kritikai kiadása: RMKT XVII/12, 44. sz.

${ }^{77}$ Az asszonyi állhatatlanságra hozott hasonlat egyik előképét a Titus Vespasianus Strozzához írott Janus Pannonius-elégiában fedezi föl Eckhardt: „Tunc levibus levior stipulis et fronde caduca”. (Kerényi Grácia fordításában: „,könnyü szalmánál könnyebb s hulló falevélnél”; 1. Janus PANNONIUs Munkái latinul és magyarul, szerk. V. Kovács Sándor, Bp., Tankönyvkiadó, 1972, 259, 33. sor.) Vö. ECKHARDT Sándor, Balassi Bálint irodalmi mintái (befejezö közlemény), ItK, 1913, 427, ill. BÖM, 254.

${ }^{78}$ BÓTA, i. m., 5.

${ }^{79} \mathrm{Uo}$.
} 
A De mit gyötresz... kezdetü vers a kikosarazott szerelmes magánbeszéde. Ez a szerelmes pedig úgy jár el, hogy ami mondanivalója a múló szerelemről maradt, azt korábbi ígéretéhez híven (vö. Ötvennyolcadik, 39. sor: „Ezt öszverendelém, többé nem emlittvén Juliát immár versül’”) következetesen a név feltüntetése nélkül közli. Ennek oka talán az lehet, hogy ha a senhal mindig ,, a konkrét hölgy felé irányuló szerelmi viszonyulás megjelölöje”, ${ }^{\circ 0}$ akkor az adott viszony felszámolása során szükségszerüen elveszíti jelentését. Helyére ezért a ciklus végén minden adandó alkalommal (itt és az $O$, én édes hazám... kezdetű énekben is) topikus oxymoron kerül, vagyis a jelenség szemantikai aspektusból úgy értékelhető, hogy az identifikálás a név helyett egy természete szerint egymást kizáró fogalmakkal operáló trópusra marad.

1. De mit gyötresz engem most, keserves lelkem? Nincsen anélkül is elég sok veszélyem, Hogy te is oly búval keseritesz éngem, Kin csak örül, tudod, édes ellenségem?

A soliloquium jellegű versek általában a deliberativum beszédneméhez sorolhatók. ${ }^{81} \mathrm{~A}$ Hetvenharmadik esetében ez a viszony explicit: a tanács kifejezés kétszer fordul elő a szövegben. Az érvmenet egésze oda fut ki, hogy a legokosabb lenne az egész ügyet elfelejteni (dissuasio).

2. Ha hozzád hajlana, mégsem volna csuda, De az lehetetlen, bár maga kivánna, De magad jól tudod, hogy nem is kívánja, Azért felejts el, mert nincs több orvossága.

Az énekböl ugyanakkor nemcsak az olvasható ki, hogy miért kell felejteni, hanem (retorikai müködését véve szemügyre) az is, hogy hogyan. A következő strófában az argumentációt példák erösítik:

3. Ily háládatlanság nemcsak rajtad esett, Sámson is csak szép Dalila miatt veszett, Ellenség kezében Fulviust mi ejtett, Ha nem felesége, kivel ö sok jót tett?

A fentiekből kitünik, hogy az ismertetett helyzet banalitásán túl maguk a példák is elég keresetlenek: úgy a bibliai (Sámson és Delila), mint a történeti (Fulvius) kellően közhelyesek

\footnotetext{
80 Szigeti Csaba, A Senhal: a név neve, Palimpszeszt, 10. sz. http://magyar-irodalom.elte.hu/palimpszeszt /10_szam/13.htm [2016.01.30.]

${ }^{81}$ Vö. Ács Pál, Ratio és oratio: Rimay János verstípusai = Á. P., „Az idö ósága”: Történetiség és történetszemlélet a régi magyar irodalomban, Bp., Osiris/2000, 2001, 52-68.
} 
annak beláttatásához, hogy az egész ügyben semmi rendkívüli nincsen. ${ }^{82}$ Hovatovább a háládatlanság - szemben az esküszegéssel - még csak nem is büntetőjogi eset. Ennek felismerése viszont az illetékesség kérdéséhez vezet.

4. Egyéb bün jutalmát az fejedelmekre Bizta Isten, e földi törvéntévőkre, De az háládatlanság szörnyü vétkére Maga visel gondot megbüntetésére.

5. Azért bizd öreá bosszúd megtorlását, Higgyed, megmutatja rajta is ostorát, Feledékenséggel viseld szived kárát, Mert az nyerhetetlen másnak adta magát.

Az ügy áthelyezése (status translationis) nagyjából ugyanazt sugallja, amit az általánosító exemplumok, vagy az elhagyott senhal: hogy a lírai alanynak mind kevesebb a köze a lírai tárgyhoz.

Annak ismeretében, hogy Balassi 1592 körül pert indított Losonczy Anna ellen, ${ }^{83}$ a fentieket azzal szokás kommentálni, hogy önnön bosszúállással kapcsolatos tanácsát végül mégsem fogadta meg. ${ }^{84}$ Valójában persze mindez inkább azt mutatja, hogy a fin'amors elsősorban diszkurzív természetü jelenség: illetlenség lenne, ha a gáláns szerelmes rosszat szólna hölgyéről - versben.

6. Lám, mind szivet, elmét, Isten nem rosszt adott, Hát miért kesergesz? Ne hadd el magadot! Szemérem ez töled, ki másnak tanácsot Szoktál gyakran adni, hogy bú igy meghajtott!

7. Ébredj fel azért már keserves sok búdból, S ne gondolkodjál ez rút bosszúállásról, Bizonyits evvel is meg, hogy szereted jól, Mert nem illik hozzád, hogy róla gonoszt szólj.

A szereztetés körülményeinek ismertetése után az ének végül kilép a magánbeszéd kereteiből. A benne foglalt hiperbolikus konklúzió személyi érvei egyébként szintén kiváló eszközei az általánosításnak:

8. Háládatlanságán sírván szeretömnek, Mostan szerzetteték tölem ez kis ének,

\footnotetext{
${ }^{82}$ Utóbbi történet forrását Eckhardt Baptista Fulgosius a 16. század során többször kiadott, rendkívül népszerü, Balassi által sem csak ehelyütt felhasznált példatárával (Factorum Dictorumque memorabilium libri IX.) azonosítja. Vö. ECKHARDT, i. m., 428.

${ }^{83}$ Vö. ILLÉSsY János, B. Balassi Bálint egy pöre, ItK, 1910, 193-197.

${ }^{84}$ Vö. BÖM, 253.
} 
Kiben az a tanács légyen mindeneknek,

Hogy senki ne higgyen soha szerelmének;

A tanács azonban végül vádolásba fordul. Az illustratio (a dolgozat elején idézett utolsó versszak) conditio és sexus baljós együttállását jeleníti meg, ennek képei azonban Eckhardt gyanúja szerint tehát szintén kevéssé egyediek a kor irodalmában; azokat és általában a Balassi költészetében helyenként tetten érhető nőellenes toposzokat a középkori moralizálás hagyatékaként tárgyalja. ${ }^{85}$ Bizonnyal így van, ám a fentiek fényében úgy tünik, mindez elsősorban a sokadik eszközként kínálkozik a hosszúra nyúlt, de rosszul végződött Júliaszerelem nagyszerüségének cáfolatára.

Ezzel szemben a Madách-Rimay-kódexek tárgyalt versének beszélője homlokegyenest ellenkezően vélekedik saját helyzetéről; egyenesen példaértékünek érzi azt. Ez az attitűd azonban óhatatlanul is tapasztalatlanságot sugall, s ez teszi olyannyira ifjontivá a külvilágnak alkotott önarcképet:

1. Nagy példát adhatok énrólam mindennek, Senki ne szolgáljon dühödt szerelemnek...

Az öntudatos felütés legtisztábban a Ferendum et sperandum c. - a tárgyalt versekhez hasonlóképpen bizonytalan szerzőségü ${ }^{86}$ - költemény 3 . versszakával cseng össze: ${ }^{87}$

Rólam vehet ebböl, mint egy szép tükörböl magának minden példát,

Mert azmint rám osztá, tôlem úgy elrántá szerencse adományát,

Ki kedvemre éltem, kell immár követnem számkivetésnek kínját.

A közhelyes szófordulat egyes szám első személyü megfogalmazásban a 16. század magyar nyelvű versanyagában ritka ugyan, de nem egyedülálló. ${ }^{88}$ Szilasi László ez utóbbi ének

\footnotetext{
${ }^{85}$ Uo., 426.

${ }^{86}$ Vö. ,,A Ferendum et Sperandum (Forog az szerencse) szerzője is B. B. ismeröse lehetett: ezt a szép költeményt 1604-ben irta az ismeretlen költö Balassi verseire emlékezve." ВÖM, 253.

${ }^{87}$ Kritikai kiadását ld.: Régi Magyar Költők Tára, XVII. század, 1, A tizenöt éves háború, Bocskay és Báthori Gábor korának költészete, szerk. KLANICZAY Tibor, StOll Béla, s. a. r. BISZTRAY Gyula, KlanICZAY Tibor, NAGY Lajos, STOLL Béla, Bp., Akadémiai, 1959 [a továbbiakban: RMKT XVII/1.], 80. sz. A szövegpárhuzamra Ötvös Péter hívta fel a figyelmemet.

88 „Csak énrólam erre példát végyenek”, SzTÁRAI Mihály, Mindenkoron áldom az én Uramot... (XXXIV. Psalmus), 20. sor = Régi Magyar Költök Tára, V: XVI. századbeli magyar költök müvei, 154?-1560, kiad. SZILÁDY Áron, Bp., 1886, 88-91.; „Példát vehet minden énrólam”, SZEGEDI István, Hálát adok néked, Úristen..., 36. sor. = Régi Magyar Költők Tára, VI: XVI. századbeli magyar költők müvei, 1545-1559, kiad. Szilády Áron, Bp., 1896 [a továbbiakban RMKT XVI/6], 6-7.; „Énrólam példát ez dicséretben mind ez világ vegyen”, SZEGEDI Gergely, Szent Dávid király bünei ellen igy panaszolkodik... (VI. Psalmus), 51. sor = RMKT XVI/6, 218-220.; „Rúlam tanuljatok, te szép asszonyok, / Példát vegyetek, szép menyek, leányok!”, Páris és Görög Ilona históriája, 1061-1062. sorok = Régi Magyar Költök Tára, VIII: XVI. századbeli magyar költők müvei, 1566-1577, kiad. DÉZSI Lajos, Bp., 1930 [a továbbiakban: RMKT XVI/8], 135-168.; „,Sok szép szüzek, életem példa legyen", ENYEDI György, Gisquardus és Gismunda históriája, 1004. sor = RMKT XVI/8, 222258.
} 
esetében - a korábbi szakirodalom által kimutatott Balassi-reminiszcenciákat elemezve ${ }^{89}$ alighanem mégis teljes joggal származtatja azt Balassi Bálint Szabadsága vagyon... kezdetü versébö1. ${ }^{90}$ Vö. 7. vsz.:

Vehetnek ifiak, vének példát énrólam,

Én nagy szerelmemben mennyi nyavalyát láttam,

Néha mint örültem, néha kesergettem, mint nyughatatlankodtam.

Szilasi végül arra az eredményre jut, hogy a Ferendum et sperandum alapvetően strofikus természetű Balassi-imitációkkal él, s hogy ez a technika jellemzi általában véve a 17. század eleji költészeti gyakorlatunk egészét is. ${ }^{91}$

Ehhez a tárgyalt vers alapján hozzátehetjük, hogy az elődszövegek ráadásul adott esetben koncentráltan idéződnek meg: szintén Eckhardt megfigyelése, hogy az első két sorban a De mit gyötresz... nyolcadik versszakának második fele variálódik. ${ }^{92}$ Az egyik fontos különbség a kettő között, hogy az előbbi tanács, ez utóbbi pedig példa kíván lenni, noha a valódi (tárgyon kívül eső) példázat - szemben a Balassi-verssel - a továbbiakból elmarad. Vagyis a fenti sor nem exemplum, sokkal inkább argumentum: a szerelmes korábbi tetteit hozza érvként a lebeszélésre. A másik, hogy ha a dühödt szerelem mibenlétét a fenti sor alapján nem is lehet pontosan meghatározni, az mindenesetre világos, hogy noha általánosságban beszél, a nőgyülöletnek is beillő totalizálás alapvetően nem célja. Eleganciája mégis messze elmarad a Hetvenharmadiktól - abban oxymoron, ebben tömör, ám annál ízetlenebb főnevesült melléknevek jelenítik meg a régi szeretőt. Először a strófa második felében:

Mert utat ad vele nagy szügyörtelemnek,

Hálójába akad ha tökéletlennek.

A retia amoris metaforája elsősorban Ovidius $A$ szerelem müvészete és $A$ szerelem orvosságai c. müveire vezethető vissza. Balassi az alakzatot egy Angerianus-fordítás színesítésére alkalmazza - annál is érthetetlenebb, hogy a Balassa-kódex negyvenegyedik számú éneke (Széllyel hogy vadásza...) argumentumában miért kap helyet az az állítás, mely szerint a

\footnotetext{
89 „Onnan [ti. a Balassi életmüből] ered mindenekelött a bujdosás témája (44., Mindennap jó reggel..., 3. strófa, 65., Pusztában zsidókat..., 2. strófa), amely Balassinál köznapi értelemben, vallásos kontextusban és szerelmi jelentésben egyaránt felbukkan [...] Onnan ered (18., Szabadsága vagyon..., 7. strófa) a szöveg domináns trópusa: a személyes exemplum használata, az a gesztus, hogy a beszélö önmagát kínálja fel az adott állitás elsödleges narrativ argumentumaként. S onnan erednek végül az elhagyatottságnak (63., Az én jó Istenem..., 5. strófa), a tavasznak (11., Áldott szép pünkösdnek..., 7. strófa) és a romlásnak (47., Idővel paloták..., 3. strófa) a szövegben fellelhetö ábrázolásai is. " SZILASI, A sas és az apró madarak, 39.

${ }^{90}$ Uo., 40.

${ }^{91}$ Uo., 41. ill. 57.

${ }^{92}$ V̈̈. BÖM, 254.
} 
szöveg szóról szóra (de voce ad vocem) az olasz költő De Caelia venante c. versét követi. ${ }^{93} \mathrm{~A}$ vadászó hölgyeket egymástól megkülönböztetni csak a tetteik alapján lehet; lévén a vadászat istennőjétől eltérően Julia - így Balassi - a hálójával kizárólag férfiakat ejt foglyul.

5. De csak szarvasokat és egyéb vadakat vér és vadász Diana,

De vitézek között szerelmére kötött s fogott sokot Julia,

Senki el nem szakad, valakire akad, mert erös ö hálója.

A szerelem hálója ugyanakkor egy Rimay-költeményben, a Szólítván nevemen... kezdetüben is megjelenik. $^{94}$

4. Minek rossznak való az szerelem-háló felteritett kötele,

Ésszel, okossággal, vidám józansággal szükség, hogy legyen tele,

Az, aki kévánja, hogy búal ne bányja, s legyen áltmenetele.

Csakhogy amíg Rimaynál a hálót trópusként is föképpen a szövevényesség jellemzi, ${ }^{95}$ addig a Nagy példát adhatok... esetében szimplán közhelyes allúzió. Ezzel együtt feltűnő a hasonlóság az utóbb idézett két szöveghely értelmében: az iménti strófában felsorolt jellemvonások nyilván távol esnek a dühödt szerelem szolgálóitól. Vegyük hozzá, hogy a tökéletlen kifejezés a tárgyalt versben kétség kívül a tökéletes, mint (el)tökélt ellentéteként értendő; vagyis elsősorban erkölcsi hiányosságra utal, amennyiben elhatározásra való képtelenséget jelent. ${ }^{96}$ Magyarán az elbeszélő legfőbb gyötrelme szerelme változékony szándékából adódik, tehát az alapélmény most is - akárcsak a De mit gyötresz... kezdetü énekben - a kikosarazottság. A század derekán a megcsalatottság eminens verselője, gróf Balassa Bálint a tárgyalt szövegekéhez hasonló terminológiával int búcsút önéletrajzi drámájának alábbi (463-470.) soraiban: ${ }^{97}$

\footnotetext{
Éljen jókban, kívánom azt,

Mint ékes szerelmemnek,

Orvosságot sem kérek mást

Szívbéli gyötrelmemnek,

Mert szerelem oly háló,

Hogy ura sok sziveknek,

De nem bolondnak való,

Sem változó szíveknek.
}

\footnotetext{
${ }^{93}$ Vö. CSEHY Zoltán, Ámor végzetes kalandja Caeliával: Girolamo Angeriano Erotopaegnion címü kötetének viszonya a szerelmi dedikációs verskötetek korabeli konvencióihoz, Irodalmi Szemle, 2007/1, 9-21.

${ }^{94}$ Vö. BALÁZS-HAJdU, JANKOVITS, PAP, i. m., 25.

${ }^{95}$ Uo., 25-29.

${ }^{96}$ Ld. a Czuczor-Fogarasi vonatkozó címszavát: A magyar nyelv szótára, VI, szerk. CzUCzOR Gergely, FOGARASI János, Bp., 1874, 395.

${ }^{97}$ VARGA Imre, Gróf Balassa Bálint magyar nyelvü önéletrajz-drámája 1643-ból, ItK, 1979, 443.
} 
Mindenesetre a nagyszerü eset leírása ezzel tkp. ki is teljesedett, az ügyben több részlet nem derül ki. A következő strófa főleg szinonimák mentén épül, és egy szentencia zárja:

2. Méltó személy, magad ne kösd méltatlanhoz, Csak szódot se nyújtsad az állhatatlanhoz, Mert ha rozsda nem is, penisz fér aranyhoz, Rossznak társasága elmédnek bút s kint hoz.

Mielőtt ez utóbbira rátérnénk, meg kell jegyeznem, hogy ez a rímelés élénken emlékeztet a Pöngését koboznak... kezdetű ének 3. versszakának megoldásaira (11-12. sorok):

Sipszónak az szava jó az serkorcsmához,

De koboz pengése elmetörödést hoz.

Ugyanakkor el kell ismerni, egy állandósult szerkezetnek az adott raggal homonim tagja aligha bizonyítja önmagában az egyébként fizikailag közel eső szöveg direkt hatását.

Bóta további képi-nyelvi párhuzamosságok kimutatásával (ha nem is a szerelmes versek anyagából merítve) két Rimay-helyre hívja fel a figyelmet. ${ }^{98}$ Az egyik a Minden dolgok között... kezdetü ének harmadik strófájából való (10. sor):

Mint fényes acélhoz sokszor rút rozsda fér...

A másik a Tarts meg, Uram, engem... kezdetü tizenegyedik versszakából (41-42. sor):

Az Úrnak ö szava tüzben megfött ezüst,

Hétszer tisztittatott, kin rozsda ki nem üt...

Ehhez két kiegészítést szeretnék füzni. Az egyik, hogy Bóta érdeklődése vélhetőleg az arany (és általában a fémek) mellett csupán a rozsdára irányul, a penészre már nem, ezért nem kerül látóterébe az Elogium hatodik sora: ${ }^{99}$

Arany írásodban nincsen peníszes ón...

A másik, hogy a fenti parallelizmusok kivétel nélkül csonkák: a Nagy példát adhatok... szentenciájának három eleméből (nemesfém, rozsda, penész) a többi ének mindig csak kettővel operál. Végső soron úgy fest, mintha a tárgyalt vers ötvözné ill. (újfent) összesűrítené a Rimay-citátumok metaforáit. Persze az is lehet, hogy éppen fordítva van: ti. hogy azok aprózzák szét a beazonosítatlan forrású aranymondást.

\footnotetext{
${ }^{98}$ BÓTA, i. m., 12-13.

${ }^{99}$ Vö. NAGY, i. m., 13-14. Az Elogium és a tárgyalt korpusz viszonyára a Hárfa ...at valahova juthat... kezdetü ének tárgyalása során térek ki bővebben, ld. a vonatkozó fejezetet.
} 
Végül a variánsok egymáshoz való viszonyáról a következők mondhatók el. A Nagy példát adhatok... záró strófája jelentésében nem tér el a Balassi-szakasztól. A Balassi-változat úgy építkezik, hogy a szakasz elején még szenvedőnek (patiens) ábrázolt alakok a végére cselekvőnek (agens) mutatkoznak. Az ezt kifejező állítmányok (indulnak ill. ejtett) a tárgyalt énekben azokkal szinonim jelentésü, azonos tövű szavakra cserélődnek (hajlók ill. hajtott). Csakhogy ezek a Hetvenharmadik címüben is előfordulnak (ld. 5. és 24. sorok). Feltehető ezért, hogy a mívesebb figura etymologica alapjául szolgáló tő szintén a Balassi-vers rezonanciájaként került át a tárgyalt énekbe. Bóta korrekciója azonban nemcsak elfogadható, de tovább is gondolható: mivel tehát búra hajtani és búra ejteni egymás szinonimái, az egész alakzat lehet pusztán annak az emléke is, hogy Madách (vagy akár egy korábbi scriptor) másolói képességeit e ponton újfent meghaladta a magára vállalt feladat.

A két strófa jelentése közötti biztos (és lényegi) eltérés tehát mindösszesen a hívságszó kifejezésből adódó többlet. Varga Imre a kritikai kiadás jegyzeteiben ezt hivalkodó szóként, hazugságként magyarázza. ${ }^{100}$ Ezt elvileg lehetne úgy is érteni, hogy az ingadozó menyecskék hajlamosak lehetnek felelőtlen ígérgetésre, csakhogy a hypallage alakzatának ilyesfajta kieszközlését feltételezni e korszakban meglehetősen anakronisztikus elképzelésnek tünik; a magyar költészet történetében a szellőcskét rázó nyírfalevél képe legalábbis még várat magára néhány évszázadot. Ebben az esetben tehát arról lenne szó, hogy egyesek nem bizonyulnak elég elkötelezettnek: noha már szavukat adták valamire, mégis hagyták magukat befolyásolni mások locsogásától.

Júlia esküszegésének okát csak találgatni lehet, arról a Balassi-versanyag hallgat. ${ }^{101}$ Nem úgy a tárgyalt énekben, melyből az tűnik ki, hogy a beszélő kedvesét egyszerüen elszerették. Ráadásul versben elmondva fölöttébb kínosan hat annak a körülménynek a belátása, hogy a költő bár talmi, mégis az övéinél megindítóbb szavakkal szemben maradt alul.

\section{Összegzés}

Köztudott, hogy a Nagy példát adhatok... kezdetű ének záró versszaka Balassi Hetvenharmadik c. versének illustratióját variálja. Abban mindenesetre az imitált szöveg

\footnotetext{
${ }^{100}$ Vö. RMKT XVII/12, 734.

${ }^{101} \mathrm{Vö.} \mathrm{BÖM,} 253$.
} 
retorikai eszközeinek koherenciája nem lazul föl, sőt helyenként még sürüsödik is. A versek egészét tekintve az elkülönböződés igénye leginkább az argumentációs technikában ragadható meg: míg a De mit gyötresz... kezdetü énekben példák erősítik az érveket, a tárgyalt vers érvekkel példáz.

További eltérés az elrendezésben figyelhető meg. Míg a strófa a Hetvenharmadik befejezéseként afféle közhelyes appendix, itt a dispositio szervesebb része. Hogy pedig informatívabb is az elödszövegnél, részben azzal magyarázható, hogy a vers (szemben a Balassiéval) nem része nagyobb kompozíciónak. Sikerültsége azonban éppen emiatt lehet kérdéses: különösnek tünik, hogy az accusatióba torkolló beszéd közepette saját költői nyelvének meggyőző ereje fölött kényszerül lesújtó ítéletet mondani. 


\section{Ki-ki terhét vállán közülünk viseli...}

Az ének négy strófából áll, metruma négysoros felező tizenkettes, izorímes. ${ }^{102} \mathrm{~A}$ bemutató beszédnemhez sorolható, mégis jól kivehetően példázatként íródott, s abban a beszélő - a gyüjtemény előző darabjában foglaltakhoz hasonlatosan - korábbi tetteit és mondásait (ante acta dictaque) tünteti fel mintegy viselkedésmintaként. Inkább nevezhető szerelmi témájúnak, mint szerelmesnek. Ez pedig elsősorban abból adódik, hogy az erkölcsi jót illető kijelentései nemcsak a szerelemre, hanem az arról való beszédre is vonatkoznak, vagyis a szöveg (ön)reflexív.

1. Ki-ki terhét vállán közülünk viseli, Az az mesterember, ki búját jól éli, Shirit ö titkának maga nem neveli, Boldogsága részét csendes kedvvel éli.

Nem a moralizáló hangvétel az egyetlen, ami a tizenötök gyüjteményéből ezt az éneket teszi leginkább hasonlatossá Madách Gáspár szerzeményeihez; Madáchot idézi még a hallgatás általa több alkalommal megverselt motívuma is. ${ }^{103}$ Bóta László a szerzőséget illetően azonban úgy nyilatkozik, hogy amíg a tartalmi megfelelések tekinthetők véletlenszerü egybeesésnek is, addig „az egyes versmondatok [...] intonálása viszont tagadhatatlanul Rimay stílusára utal. $" 104$

Ami az első állítást illeti, Bótának igaza van abban, hogy attribúciós kérdésekben az általa megfigyelt párhuzamosságok önmagukban véve nem perdöntőek. De - tegyük hozzá éppen a vizsgált költők egymáshoz való viszonyának ismeretében kétséges az életmüveikben fellelhető szintaktikai, frazeológiai, motivikus (stb.) áthallások véletlenszerüsége is. A második állítás kapcsán azonban felmerül a kérdés, mit érthet Bóta „intonáció” alatt. Erre a hitelesnek tekintett Rimay-versanyag következő idézeteiben kell keresnünk a választ. Az egyik a Venus, fajtalan hús... kezdetü ének alábbi strófája: ${ }^{105}$

4. Az a dicsiretes, dolgaiban nyertes, mint sok bölcs bizonyítja, Gyönyörüségire s kivánt örömire szivét ki fel sem nyitja, Minden kedvelt javát, ki neki bántást ád, tüle messze hajítja.

\footnotetext{
${ }_{102}^{102}$ A vers kritikai kiadása: RMKT XVII/12, 45. sz.

${ }^{103}$ Madách Gáspár költői habitusának részletesebb körülírására az appendixben (A Rimay-örökség Madách Gáspár tollán) kerítek sort.

${ }^{104}$ ВÓTA, i. m., 13.

${ }^{105}$ Idézi Bóta; $U o$.
} 
A második parallelnek ítélt passzus forrása ( Ez világ mint egy kert) nem a szerelmi, hanem a politikai tárgyú versek közül való: ${ }^{106}$

10. Okosson kell azért ez rossz időbe ért állapatunkot élni, Sziviünnek keservét, kit nap ránk heven vét, hogy le tudjuk metélni, Az az jó kormányos, ki, ha az víz habos, nem tudja tengert félni.

11. Mint habzó tengerben, mi is ez életben evezönket forgassuk, Kínnal mi lelkünket, sok gonddal fejünket igen ne nyomorgassuk, Isten sok jókot ád, csak szelinknek zúgtát csendesz szivvel hallgassuk.

A fentiek alapján azt lehet gondolni, Bóta észrevétele elsősorban bizonyos szintaktikai jellegzetességekre vonatkozik. A legszembetűnőbb hasonlatosság ugyanis a tárgyalt vers első strófája és az idézett példák között a mondatszerkesztésben mutatkozik: ezek főmondatában az $a z$ mutató névmás, mellékmondatában pedig az aki vonatkozó névmás tölti be az alany szerepét. ${ }^{107}$ Ugyanakkor meg kell említeni a citátumok argumentációs technikáinak egyezését is. A genus deliberativum mindig jövő idejü tettekre irányul, azok elhatározását készíti elö, ezért abban az érvmenet a meghozandó döntés lehetséges indokaiból építkezik. Ugyanakkor az, hogy az érvelés mindhárom vers esetében lélektani okokra épül, s azon belül is kifejezetten a rossz elkerülésének egy-egy módozatát (kisebbités, kikerülés, elviselés) mutatja be, aligha független attól az eredménytől, hogy e verseket nagy általánosságban sztoikus világképűnek szokás nevezni. ${ }^{108}$ Hogy a tárgyalt ének éppen szerelmi tárgyú, az arany középutat hirdető felütésből tkp. nem is derül ki, csak a következő részekből.

2. Engem hát szerelmem, ki tüziben nevelt,

Nem csudálhatom-e, hogy lángom el nem nyelt,

Ki magának most is marasztott bennem helt,

Érezö gyötrelmim adhatnak nektek jelt.

\footnotetext{
${ }^{106}$ Idézi Bóta. Uo.

${ }^{107}$ Hasonló szintaktikai szerkezetet találni a Valjon s de mi haszon... kezdetủ énekben is: „Így az a jó kegyes, azkinek sok nemes ifjú legény udvart áll." (RÖM, 17. sz. 5. sor.) Ebből az tủnik ki, hogy Rimay ezt a szórendet csak Balassi-strófában írt verseiben alkalmazza, másutt nem. Ugyanakkor pl. Madách Gáspár megpróbálkozik azzal felező tizenkettesben (a tárgyalt verssel megegyező ritmusban) is: „Az az jó tebenned, ki nagyot hazudhat." (Szodomához hasonló..., RMKT XVII/12. 39. sz. 17. sor.)

${ }^{108}$ Rimay sztoicizmusának ellentmondásosságairól írva Zemplényi Ferenc épp e fogalmak mentén látja gondolati költészetének egyes helyeit inkább az epikureizmushoz közelítőnek, a kettő közti különbséget így fogalmazva meg: „Nem kötelességteljesités és összeharapott száj, hanem kitérés, kivárás, csöndben maradás.” (ZEMPLÉNYI Ferenc, Müfajok reneszánsz és barokk között, Bp., Universitas, 2002 (Historia Litteraria, 11), 140. Kiem. tölem. B. P.) Ebben a megközelítésben talán nem teljesen érdektelen Madách azon parafrázisa sem, amely az élet mint tengerhajózás toposzát is érinti (Sokáig való éltedet ne kivánj..., RMKT XVII/12, 25. sz. 6. vsz.). Ennek mondanivalója elsősorban a túlvilági üdvözség kívánatossága az evilági élettel szemben - vagyis a rossz elkerülésének föntebb látott típusai helyett a fö érvet a szabadulásban (liberatio) látja. Ez a meglehetősen középkorias gondolatvilág pedig már tökéletesen idegen a lipsiusi állhatatosságtól. Mint ahogy azt az előző fejezetben is érintettem, az udvarló típusú szerelmi költészetnek mindig is a jó elérése, azon belül is használatba vétel (usus) a legfőbb célja.
} 
De a Rimay-hagyaték egyes Madách Gáspár másolatában fennmaradt darabjait idézik az első két strófa rímszavai (viseli, éli, neveli ill. nevelt, nyelt, helt, jelt) is. Egészen pontosan a Leges mensales c. ének (Ez asztalhoz mostan ...) 3. versszakát:

\author{
Gözködö italnak se legyen itt helyje, \\ Tobzódással magát senki se terhelje, \\ Mit gyomrában betölt, azt meg is viselje, \\ Okádta moslékát se nyalja, se nyelje.
}

Illetve az Encomia et effecta virtutum c. ének (Itt egy asztalt látunk) 31. versszakát:

\begin{abstract}
Mert mint avult börit kígyó nem viseli,
Csintalanságával magát nem terheli,

Így okos keresztyén vétkét nem neveli,

Rútságát szépségén örömest cseréli.
\end{abstract}

Nagy Ferenc idézett dolgozatában az első két strófa ellentmondásosságára hívja fel a figyelmet, miszerint „,a bú (2.) és titok (3.) bölcs elhallgatásának programjához nem lehet a szerelmi gyötrelmekről való széles körü jeladás (8.) programját következmények nélkül hozzákapcsolni. "109 Csakhogy ezek mondanivalója mégsem teljesen következetlen. A mester tehát az, aki rezignáltan örzi titkát, vagyis az élményt minimum nem avatja verssé $-\mathrm{s}$ a beszélő alkalmasint éppen arról vall, hogy személy szerint ő éppen nem így járt el. Ezt azonban nem tudja másként, mint a szerelmi költészet legközhelyesebb képei segítségével közölni.

3. Tisztelem az elme vezetett tudománt,

Hogy tüzének habja eröm felett nem hat,

Megnyertem jobb részit, mint az lelkem kinját,

Vakmerön netalám az Cupido sem bánt.

Vagyis a szerelem fölötti kontrollt gyötrelem ugyan kialakítani, ámde csak az véd a szerelem tüzének habjától ${ }^{110}-\mathrm{s}$ ez utóbbi alakzat végképp arról győzi meg olvasóját, hogy az újonnan vázolt szerelmi gyakorlathoz egyáltalában nem tartozik önálló, az elutasítottól különböző terminológia. ${ }^{111}$ A tárgyi peroratio érve ezúttal is a kikerülés:

\footnotetext{
${ }^{109}$ NAGY, i. m., 14.

${ }^{110}$ E képre Bóta Enyedi György Gismunda és Gisquardus históriája c. művében is ráismer (Vö. BóTA, i. m., 6., 12. lábjegyzet): „Szerelemnek olthatatlan tüz lángja, / Ez vitt engem sebes tüze habjába.” (411-412. sorok. Kritikai kiadását ld.: RMKT XVI/8, 222-258.) Azonban a párhuzamot nem a szerzőség ügyében hozza föl érvként, hanem egy - általa - homályosnak tartott szöveghely tisztázására. Az 6. sorban ti. szövegromlást gyanít; szerinte a „Nem csudálhatom-e, hogy lángom el nem nyelt” (Kiem. tőlem. B. P.) félmondat értelmetlen, s a helyes alak a párhuzamból kivehetően lángja lenne.

111 A korábbi szakirodalom (értsd: BÓTA, i. m.) módszerét folytatva jelzem, hogy amíg a vakmerő szó sem Balassi, sem Madách költői életmüvében nem fordul elő, addig Rimaynál öt esetben is; vö. RÖM 41., 49., 60.,
} 


\section{Az méltó szerelmet mindenkor becsülöm,}

De kész szemérmével ö küszöbit ülöm,

$S$ dühödt természetit, mint illik, kerülöm,

Lelkemet rossz gonddal mert nem is terhelem. ${ }^{112}$

Az önmegtartóztatás e meglehetősen átlátszó metaforikáját fölösleges magyarázni, ugyanakkor az előző versben (Nagy példát adhatok...) is megjelenő szófordulatok ebbéli szövegkörnyezete azokat is egyértelmüsíti: a méltó alighanem a tiszta, a dühödt pedig a testi szerelem következetesen alkalmazott jelzője lehet - hírét adni pedig vélhetően ez utóbbinak lehet káros.

Korábban már esett szó arról, hogy ha Madách Gáspár szerelmi költészetének emléke nem is maradt ránk, moralizáló parafrázisai között azért találni olyat, melyben (a tárgyalt vershez hasonlóan) a szerelmi titoktartás szükségességéről értekezik, s hogy a hallgatás motívuma ezekbe jószerével az udvari élet egyéb protokollját tárgyaló költeményeiből származhatott át. $^{113}$

A tárgyalt vers kapcsán ehhez a következő kiegészítés tartozik. Lényegében mindegy is, tudatában van-e Madách annak, hogy a következő idézetben a bölcs megnevezés mint antonomasia Szókratészt takarja, vagy sem: Krónika c. versében ${ }^{114}$ a korabeli általános sztoicizáló hajlamnál kivehetően praktikusabb megfontolások íratják vele az alábbi sorokat.

22. Jobb az nyelvet szájban kevéssé megfogni,

Hogysem szók után azután bánkódni,

Az bölcs embernek mondásával élni,

Hallgatásnál nincs jobb, azon megnyugodni.

23. Azért azki hallgat, az jól uralkodik, Nyelve fékemlöin nemigen hánkódik, Fekszik csendesen, örül, nem bánkódik, Nyelve hazudságát nemigen növetik.

Érdemes megfigyelni, hogy Madách nem az általában értett sokbeszédűségtől, hanem kifejezetten a nagyotmondástól inti óva az érintetteket. E versszakok kevés változtatással

64., 65. sz. versek - jellemzően egyik sem szerelmi témájú. Valamint igen érdekes, hogy a Madách szerzőségének gyanújától szabadulni alig képes Varga Imre e strófa harmadik sorának második felét ekként javítaná: ,, mit az lelkem kivánt” - vagyis értelmi romlást feltételez az egyes korábbi álláspontok szerint autográf kéziratban.

${ }^{112}$ Emlékezzünk: az utolsó sor rímszava szintén megjelenik a Leges Mensales és az Encomia et effecta virtutum c. versek idézett strófáiban.

${ }^{113}$ Vö. az appendix (A Rimay-örökség Madách Gáspár tollán) 576. lábjegyzetével.

${ }^{114}$ RMKT XVII/12, 38/I. sz. 
megjelennek a Libellus Elegantissimus egy disztichonjának megrímelt kifejtésében (Ha te jól élsz...), ott azonban már (a forrásszöveg értelmének megfelelően) a rágalmazás ellenében. ${ }^{115}$ A két variáns konklúziója azonban már határozottan eltérő. A Krónika példaértékü történetei az Újvilág aranyfejszéiről, a tiszántúli óriásdinnyékről és a Kékkő melletti hatalmas röpképtelen madárról mind ugyanarra a tanulságra futnak ki, melynek értelmében a hivatali előmenetelt kár kockáztatni hiteltelen történetek terjesztésével:

26. Nyelved miatt néha nem mersz elömenni,

Ha hazugságodat nem tudod fedezni,

S mégis mindazáltal jól tudsz nyelveskedni,

Hazugságot hazugsággal nagyon újítani.

A Ha te jól élsz... kezdetủ (s a madáchi Cato-parafrázisok többi darabja) ugyanakkor érezhetően nem ugyanahhoz a közönséghez szól, mint a Krónika, hiszen eleve valamiféle provinciális udvarellenesség sugárzik belőle. Ennek manifesztációjaként az udvart egyenesen olyan hírhedt helynek írja le, ahol tipikusan intrikákkal lehet jó pozícióba kerülni. ${ }^{116}$ Éppen ezért a tanulság ez énekben úgy módosul, hogy - előmenetel ide vagy oda - bárminemü tisztség efféle jól bevált elérésével szükségszerűen elvész a tisztesség is, vagyis (képes beszéddel élve) a sárdobáló magát is besározza.

9. Nyelved miatt néha nem mersz szemben nézni

Kit azelött rútul szoktál rágalmazni,

Nem vetted eszedben, hogy magad gyalázni,

Rút iszapos sarat az nyakadban hányni.

Ehhez az erkölcsi belátáshoz (és a hozzá kidolgozott figuratív ábrázoláshoz) Madách akkor is ragaszkodik, amikor kedves szentenciagyüjteményének egy másik tételét dolgozza fel, jelesül a IV. könyv 30. disztichonját (Borral, szerelemmel, ha lehet... ${ }^{117}$ ). Ennek fordítását a debreceni kiadás így hozza: „Az Vénusszal és az Bacchusszal (azaz a szerelemmel és az borral) háborúság is, gyönyörüség is vagyon együtt. Az mi jó (ezekben vagyon), elmídbe befoglaljad, de eltávoztassad az háborgást."118 Részegség és szerelem - láttuk - egyaránt kedves témája Madáchnak, ám a kapcsolatos (juncta) ügy összetevőinek korrespondenciáját

\footnotetext{
115 Formulae puerilium colloquiorum, Dicta graciae sapientum, Libellus elegantissimus, Civitas morum, a fakszimile szövegét közzéteszi KöSzEGHY Péter, tan. BITSKEY István, Bp., 2007 (Bibliotheca Hungarica Antiqua, 40), B5r. (III. könyv, 2. tétel.) A továbbiakban: Libellus elegantissimus. E könyvecske Madách intellektusára gyakorolt hatását szintén az appendixben fejtem ki. Madách idézett parafrázisának kritikai kiadását ld.: RMKT XVII/12, 33. sz.

116 Vö. 12. vsz.: „,Nincsen nagyobb rágalmazó szónál, / Mikoron hazugnak nyelve igen szolgál, / Hazugnak vagyon böcsi az udvarnál, / Jó erkölcsnek ottan zsoldja leszáll."

${ }^{117}$ RMKT XVII/12, 27. sz.

${ }^{118}$ Libellus elegantissimus, C3r.
} 
éppen a hallgatásra való képtelenségben meglátni - nos, ez alighanem saját invencióját dicséri.

2. Józan embernek való az szerelem,

Ki okossággal bir s mindent elfedezzen,

Csacsogásával híre semmi helyen

Ki ne terjedhessen, dolga mibe legyen.

3. Mert az szerelemben nincs jobb hallgatásnál,

Szeretödnek avval te is használhatnál,

Hogy rágalmazásra okot nem adhatnál,

Úgy maradhatnál meg csendesen meg háznál.

4. Ha az szerelemmel okkal nem tudsz élni,

Hamar ö hátárúl le kezd téged vetni,

Iszapos rút sárban kezdesz heveredni,

Lábad talpaira nem tudhatsz felkelni.

A fenti idézetek mind azt mutatják, hogy Madách számára a hallgatás elsősorban olyan magatartásként értetődik, amely bizonyos verbális természetü bünök (hazugság, rágalmazás, viszálykeltés, istenkáromlás stb.) megelőzését vagy elhárítását szolgálja. Ezt erősíti az a jelenség, hogy a hírhedten önállótlan szentenciafordításai is ilyesfajta irányt tükröznek. Erre sok példát találni az életműben (ellenpéldát viszont egyet sem), most csak az elsőt citálom: a Libellus elegantissimus első könyvének 3. disztichonját a debreceni kiadás prózafordításában, majd a Madách által megverselt változatát. Ezek: „Első jószágnak állitsad lenni az nyelvet megtartóztatni, mert legközelb az az Istenhez, azki okossággal tud hallgatni. "119 Illetve az alábbi sorok: ${ }^{120}$

Első jószágnak állitsad az nyelvet,

Zabolázással ötet felékesitsed,

Tartóztatással mindenben vezéreljed,

Igazmondással Istenhez közelitsed."

Amíg az eredetiben tehát arról esik szó, hogy Istenhez az áll legközelebb, aki okosan hallgat, addig Madách verziója szerint az, aki egyben igazat beszél. Jóllehet a kettő szinonim, az aspektus mégis más. Ami nemcsak arra vall, hogy Madách a hallgatást is etikai érdekü cselekedetnek tartja, egyéb jelentőséget pedig nem látszik neki tulajdonítani, hanem arra is, hogy - szemben éppen a Ki-ki terhét vállán... kezdetü ének szerzőjével - a lélek békéjét önmagában szolgáló csendesség fogalma meröben idegen számára.

\footnotetext{
${ }^{119}$ Libellus elegantissimus, A5r.

${ }^{120}$ RMKT XVII/12, 34. sz. 2. vsz.
} 


\section{Összegzés}

A Ki-ki terhét vállán... kezdetü ének egy lezárult szerelem emlékét és azzal együtt egy költői pályaszakasz lezárásának szándékát őrizte meg. A vers sztoikus jellege elsősorban annak argumentációs készletéből (a rossz elkerülése) rajzolódik ki. És bár ezeket mint az önmérséklet triviális kifejezőit Madách Gáspár is gyakorta alkalmazza moralizáló költeményeiben, s a tárgyalt vershez hasonlóan általában ő is a hallgatás motívumán keresztül véli elérhetni azokat, e szót (ti. hallgatás) életmüvének más, hiteles darabjainak tanúsága szerint mégis radikálisan másként: csakis erkölcsileg kifogásolható beszédaktusok kivédésének eszközeként érti - a feltételezhető szerzők köréből Madách már csak ezért is bizonyosan kizárható.

Ugyanakkor - noha Bóta László ebben az énekben is kimutat Rimayt idéző fordulatokat - a vers beszélőjének azon állítása, hogy maga nem ír több, a testiséget megjelenítő szerelmes verset, hovatovább ezt másnak sem tanácsolja, mint szikár konzekvencia aligha tükrözheti Balassi legelső tanítványának felfogását. ${ }^{121}$

Másfelől a teoretikus Rimay tervezett Balassi-kiadásának előszavában arról ír, hogy a szerelmi líra negligálása nemcsak megcsonkítja és eltorzítja, de le is alacsonyítja a költészet épületének fogalmát, valamint hogy a szerelem témakörében (Balassi által) megteremtett magyar nyelvü poézis érték, bátorság, becsület és értelem dolga. ${ }^{122}$ Ezzel szemben a tárgyalt vers mintegy programszerüen javasolja e téma elvetését, ámde az örökölt nyelvi ábrázoláson (a vonatkozó retorikai eszközkészleten) láthatóan már nem tud változtatni - vagyis ha azt feltételezzük, hogy a tárgyalt ének szerzője a nagy elődhöz kíván viszonyulni valamiféleképpen, akkor ez az imitatív stratégia a puszta megtagadásban ismerszik meg.

Mindent összevetve: a Ki-ki terhét vállán... kezdetü vers szerzőségének kérdésében tehát nem lehet többet állítani annál, mint hogy ez az ének egy, a Balassi köreihez közel álló dilettáns verselő tevékenységének olyan lenyomata, amely szellemiségét tekintve az eddigi attribúciós kísérletek során nevesített szerzők hátramaradt életmüvével bajosan egyeztethető össze.

\footnotetext{
${ }^{121}$ Balassi a Júlia-szerelem végére érve átkozza haszontalan - vagyis gyakorlati funkciójukat ellátni nem alkalmas - verseit, sőt egyenesen tüzre vetné öket (vö. Ó, én édes hazám, te jó Magyarország...,10. vsz.), de olyan ígéretet soha sehol nem tesz, hogy nem fog írni újabbakat.

${ }^{122}$ Vö. RÖM, 42.
} 


\section{Bírja bár akárki nagy jószágú Lévát...}

„Ajkadról, jegyesem tiszta méz csurog.” (Én 4,11)

Az ének négy strófából áll, metruma négysoros felező tizenkettes, izorímes. ${ }^{123}$ Első sorát a köttetés alkalmával levágták, ezért az - leszámítva az örszóként fennmaradt incipitet (Bírja bár) - csak Radvánszky közléséből ismert. ${ }^{124}$ Már a kezdő strófából kitünik a szövegcsoport egészét érintő jellemzője, hogy noha az előző darab (Ki-ki terhét vállán ...) konzekvenciája az volt, hogy az amor carnalis tárgykörében verset írni kifejezetten káros gyakorlat, az alábbi sorok szerzője attól a legkevésbé sem zárkózik el.

1. Bírja bár akárki nagy jószágú Lévát, Becsüljék sok pinzre Erdélyben is Dévát, Csak én ölelhessem karjaimmal Évát, Kit lelkem s két szemem nagy kincse gyanánt lát.

A fenti, részint helységnevekböl generált rímbokor kapcsán (valamint nyilván a Rimayéletmü közelisége okán is) az Én édes Ilonám... kezdetű dedikációs vers emléke sejlik fel az olvasóban - különösen, ha hozzávesszük Kovács Sándor Iván azon fejtegetéseit, melyek szerint a következő strófa rímszavainak ötletét egyebek mellett az „ég és föld” értelmü „Kemence s Velence” szólás adta volna, s hogy e két tulajdonnévre egyként igaz, hogy létezik homonim köznévi párjuk. ${ }^{125}$

3. Mert az te szerelmed engem úgy környülvett, mint pézsmát ó szelence, Az én szivem kivel szintén úgy hivült el, mint tüz miatt kemence, Mert te szépségedbe szivem úgy merült be, mint tengerben Velence.

Igaz, az utóbb idézett strófa formájával és három szótagos sorvégi rímszavaival verstanilag impozánsabb az előbbinél, és eltér attól retorikai felépítettségében is. Rimaynál mindhárom sor egy-egy hasonlat köré szerveződik, melyekben a hasonlítók adják ki a rímeket - szintén Kovács Sándor Iván látja meg a keresettnek tünő rímszavak logikai összetartozását, lévén azok metonimikusan a fém, a tủz és a víz elemeinek jelölői. ${ }^{126}$ Az argumentatio az ismeretlen szerző idézett strófájában is hasonlóságra épül, csakhogy abban a beszélő egyenlőtlen példák

\footnotetext{
${ }^{123}$ A vers kritikai kiadása: RMKT XVII/12, 46. sz.

${ }^{124}$ Vö. RIMAY János Munkái, 25., ill. RÖM, 163.

125 KovÁCs Sándor Iván, Egy rímtoposz diadalmenete, Újhold-évkönyv, 1988/1, 364-366.

${ }^{126}$ Uo., 373.
} 
(a városok gazdagsága) segítségével fejezi ki a szeretett nő értékét - ami ebben a megközelítésben mégiscsak egy szentírási locus (,,Ahol a kincsetek, ott a szívetek is. "127) mindenestül profán variációjaként ismerhető fel. Mozgásterét erősen beszükíti a formakényszer: a feladat, hogy minél tisztább rímeket találjon a kedves nevére. Ez a megoldás azonban idegen a teljes Rimay-versanyagtól, talán részben az alábbiak miatt is.

Balassi Bálint korai, a hagyomány szerint házassága elött szerzett verseiben többször is felfedi múzsája kilétét: a Balassa-kódex első harminchárom versének akrosztichonja több esetben a címzett teljes nevét közli, ${ }^{128} \mathrm{~s}$ ezek a köznapi nevek azután horizontálisan is megjelennek a szövegben, legtöbbször afféle személyi érv gyanánt. S hogy később ez a rutin elmarad, ennek poétikai oka a (ciklusképző) senhal megjelenése lehet: a Júlia-versek akrosztichonjai (még ha szándékoltnak tudhatók is) meglehetősen semmitmondóak, a Céliaversek pedig akrosztichon nélküliek. Érdemes megfigyelni továbbá, hogy azok a - jellemzően ciklusvégi - énekek, melyeknek akrosztichonja nincs, de más pozícióban előfordul bennük női név, az mindig valamilyen erkölcsi szempontból problematikus (inhonestum) ügy: egy bécsi virág, egy citerás lengyel leány vagy egy porcogós kurtizán emlékét őrzik. ${ }^{129}$

Balassi költői életművének egy helyén a senhal mégis feloldódik. A másként a Szép magyar komédia betétverseként funkcionáló Ötvennegyedikben (Ó, magas kösziklák) arra látni példát, hogy az erdő hangossága, vagyis az Ekhó kimondhatja azt is, amit a vers addigi beszélőjének aligha lenne ildomos: egy lapon említi a hölgy köznapi nevét a titkossal. ${ }^{130}$

3. Echo, nagy kinomba, kibe szép Julia engem vertengeni hágy, Mi könnyebbithet meg, s mitül leszen esmeg kemény szive hozzám lágy?

Régi gyötrelmimet mi enyhitheti meg, s mi az, mire lelkem vágy?

ECHO: ÁGY.

4. Ágy, igazán mondád, de mondd meg azt is hát, ott ki vigasztalhatna?

Búm helyett örömet, gyönyörü életet nékem ott ki adhatna?

Igazán ki neve, kit jómnak felette lelkem oda kívánna?

ECHO: ANNA.

5. Azt bizony megvallom, de jó szolgálatom kedves-é néki vagy nem?

\footnotetext{
${ }^{127}$ Lk 12,34

${ }^{128} \mathrm{Az}$ efféle ajánlás persze nem feltétlenül jelent udvarló szándékot, ahogy Madách Gáspár sem ebből a megfontolásból dekorálja a csehből fordított kegyes énekek versföit Czobor Anna nevével. Itt jegyezném meg, hogy Jankovics József felvetését, mely szerint Madách Az jó asszonyi állatról c., témájában őtőle szinte unikális alkotás (RMKT XVII/12, 36. sz.) versföiből (AAÉVAM) ugyanaz a név olvasható ki, mint a tárgyalt versből, megcáfolni nem lehet. Ám Jankovics azt mint az egyetlen akrosztichonos Madách-költeményt emeli ki, vagyis figyelmen kívül hagyja a négy csehből fordított éneket. Vö. JANKOVICS, A Madách Gáspár-jelenség, 58.

${ }^{129}$ Pap Balázs megfigyelése szerint azok a Balassi-költemények, melyek versföikben köznapi nevet rejtenek, nem tünnek minden kétséget kizáróan elegánsak. Vö. PAP Balázs, Az akrosztichonok és az első harminchárom, Ttáj, 2004/10, 49-52.

${ }^{130}$ A nevek kérdéséröl 1. KöszegHY Péter, Balassi Bálint: Magyar Amphión, Bp. Balassi, 2014, 295.
} 
Szép Julia-Annám lészen-é jó hozzám, s megkegyelmez-é nékem?

Hogy régen szolgálom, lészen-é jutalmom, s kell-é jót reménlenem?

ECHO: NEM.

A fentiek alapján akár azt a hipotetikus kijelentést is meg lehet kockáztatni, hogy noha a Nyolc ifjú legény... kezdetü Balassi-vers férfiszereplői többé-kevésbé rangrejtve maradnak, e diszkréció hölgyeiket - úgy lehet - szintén nem illeti meg. A módszer nagyban emlékeztet egyes korabeli leánycsúfolók (pl. Egyszer vala én életemben... ${ }^{131}$ ) praxisára, még akkor is, hogyha azok éppen fordított szerkesztésűek. A köznapi identitás felfedése ill. a kiéneklés lényege azonban közös, ráadásul mindkettő rokonítható az a nominibus fogalmával is ${ }^{132}$ talán ez is indokolja Rimay tartózkodását attól, hogy a maga szerezte ekhós versben (Kösziklák közt lakó...) mesteréhez hasonlóan női nevet helyezzen rímpozícióba.

Amíg a Madách-Rimay-kódexek szerelmes énekeire általában jellemző alkalmiság a Balassiéletmüben túlnyomórészt a korai költemények sajátja, addig alakilag a késeiekhez mutatnak hasonlóságot, s hogy pedig e megállapítás számos közköltészeti alkotásra is igaz, az úgyszintén e verscsoport félútiságának képzetét erösíti. Erre enged következtetni a vizsgált szöveg figuratív apparátusából kirajzolódó kontextus is. Az első versszak túlzó hízelkedése (insinuatio) után a beszélő kedvese személyéből; testfelépítéséből merít tényleges érvet: precíz képiséggel vezet rá a kézzelfogható értékek mibenlétére (5. sor):

Az ö fejér mellye merö alabástrom...

A kizárólagosan a nemi jellegre fókuszált habitus corporis szintén a 17. század közköltészeti gyakorlatához közelíti a szöveget, csakhogy az alabástrom szó - hiába tipikus petrarkizáló ásványmetafora ${ }^{133}$ - az énekkel kortárs magyar nyelvű szerelmi költészet egyik regiszterében sem fordul elö. Hasonló alakzatban jelenik meg ugyanakkor Balassi (az ekhós versek örvén már említett) Szép magyar komédiájában. Ebben egy helyütt Galatea így panaszkodik régi szeretőjének, Sylvanusnak: „maga egyszer az én kezeimet mondod vala gyönyöröségeseknek, hóhoz, fejér liliomhoz, alabástromhoz, azokhoz hasonlitod vala.” (Actus II. Scena III. ${ }^{134}$ ) Eszerint az ihletett szerelmes kedvesének kezét a felsoroltakhoz hasonlóan fehérsége teszi

\footnotetext{
${ }^{131}$ Fanchali Jób-kódex, 196-197. (MTAK A 280/3.) A vers kritikai kiadása: Régi Magyar Költök Tára, XVII. század, 3, Szerelmi és lakodalmi versek, kiad. STOLl Béla, Bp., Akadémiai, 1961. A továbbiakban: RMKT $\mathrm{XVII} / 3$.

${ }^{132}$ PAP Balázs, $A$ sólyom szive, Café Bábel, 51. sz., 49-53.

${ }^{133}$ Yves Giraud a petrarkista líra toposzait rendszerező táblázatát Tóth Tünde ismerteti ill. egészíti ki magyar vonatkozásokkal. Vö. TóTH Tünde, Balassi és a neolatin szerelmi költészet, PhD-értekezés, 1999.

${ }^{134}$ MišIANIK, ECKHARDT, KLANICZAY, i. m., 73.
} 
széppé. Ám az ismeretlen szerző metaforája ennél valamivel érzékletesebb: a fejér szó nála mindössze a hölgykebel epithetona, a hasonlóság valódi alapja pedig az, hogy - akár az alabástrom - merö az is, ebben az értelemben tehát hibátlan ill. makulátlan; nem rútítja szemölcs, napfolt vagy himlöhely. ${ }^{135}$

Ráadásul a Szép magyar komédia mellett a Fanchali Jób-kódex további két olyan szöveget is megörzött, amely szókészletébe az alabástrom is beletartozik: mindkettő a kódex szlovák nyelvü énekei közül való. ${ }^{136}$ Részben ebböl is adódhatott, hogy a korai recepció (tkp. a kéziratot megtaláló Ján Mišianik) e versek szerzőjének Balassi Bálintot tartotta. ${ }^{137}$ Elörebocsátva, hogy ezen álláspontot ebben a formában csak mint konszenzuálisan jó ideje meghaladott hipotézist tudom tárgyalni, most mégis összefoglalnám Mišianik sok szempontból tanulságos érveit - főleg azért, mert azok nagyfokú hasonlóságot mutatnak a Madách-Rimay-kódexek inkriminált tételeit illető attribúciós kísérletek gondolatmenetével.

Mišianik leginkább azért valószínüsítette a szlovák énekek szerzőjének személyét Balassiban, mert rajta kívül más nevesíthető költőt nem tudott gyanúba fogni. ${ }^{138}$ A versek nyelvezete középszlovák dialektust tükröz, vagyis olyan területek nyelvjárását, ahol a Balassák birtokai is voltak. Heterometrikus, nem ritkán belső rímes formákban íródtak, csakhogy a szótagszám és a rímelés gyakran el van rontva bennük. (Az összesen nyolc ének hétféle, Balassi hiteles verseiben nem használt képletet mutat). Egyes motívumok ill. fordulatok többször megismétlödnek a korpuszon belül, s ugyanezek a közhelyek fellelhetök a Balassi-életműben is. Szerelemfelfogásuk szabados. Végezetül Mišianik elismeri, Balassi szerzőségére közvetlen bizonyíték nincsen - ha tehát meg kell engednie, hogy a szövegcsoport mégis mástól való, úgy véli, az a valaki bizonyosan Balassi egy (névtelen) epigonja lehetett.

\footnotetext{
${ }^{135}$ Ez a kozmetikai ideál mintha éppen ellentétes lenne azzal, amiröl a Balassi-anyag egy helyén olvashatni. A Huszonnyolcadik c. ének (Minap múlatni mentemben...) alapszituácója szerint a beszélönek döntenie kell két, alkalmasint pénzért vásárolható kegyes szépségét illetöen. Kitérő válasz után végre így felel meg nekik: „De imhol néktek az igaz, / Szépségtekröl rövid válasz, / Szömölcsöt visel mellyén az, / Azki legszebb, kisebbik az." (5. vsz.) Persze az is lehet, hogy ítélet nem a szépségpötty, hanem az alacsony termet figyelembevételével született - ahogy Juan Ruiz is a kistermetü nök mellett teszi le a voksát a Jó szerelem könyve c. munkájában. (Juan RuIZ, A Jó szerelem könyve = Hesperidák kertje: Az ibéri világ költészete, s. a. r. ANDRÁs László, Bp., Európa, 1971, I, 39.)

${ }^{136}$ A verscsoportot az egyazon kéz másolta Egyszer vala én életemben... kezdetủ, a fentiekben példának hozott leánycsúfoló előzi meg.

${ }^{137}$ Vö. MišianiK, ECKHARDT, KLANICZAY Tibor, i. m., 149-153.

${ }^{138}$ Jellemző, hogy az attribúció megkérdőjelezéséhez szükség van egy másik szerző személyére, pontosabban annak illúziójára: „,[A] második sem lehet eredeti Balassi-költemény, mert versföiböl ezt olvassuk ki: ADAM RANTHAŽPIT. Ez nyilvánvalóan a szerzö neve, habár a különös végzödés szövegrontásból is származhatik, $s$ lehet, hogy a költöt nem pontosan igy hivták. [...] A további, XVI. századdal foglalkozó családtörténeti és irodalmi kutatástól várjuk, hogy fényt deritsen az elsö szlovák lírai költö személyére és életére." CsANDA Sándor, Balassi Bálint költészete és a közép európai reneszánsz stílus, Bratislava, Madách, 1973, 317.
} 
Visszatérve a vizsgált kifejezés előfordulásának kérdéséhez: az alabástrom szó először a negyedik vers (Pane Bože milý...) 8. strófájában jelenik meg: ${ }^{139}$

$\begin{array}{ll}\text { Kvittku muj spanilý, } & \text { Bájos virágom, } \\ \text { fiku osladilý, } & \text { édes fügém, } \\ \text { ličko tve červené, } & \text { orcád piros, } \\ \text { pery kolorové, } & \text { ajkad bíbor, } \\ \text { oči tvé sokolové, } & \text { a szemed sólyom, } \\ \text { telo alabastrové, } & \text { a tested alabástrom, } \\ \text { serdce jaspidonové. } & \text { a szived jáspis. }\end{array}$

Másodszor pedig a hetedik vers (Darovals'mne, Bože, tak...) 6. strófájában: ${ }^{140}$

Levendula prevunná,

rozmarínu se rovná;

dej, Bože, bych ho ja tež dočekala,

dočekavše telo své s ním obkladala,

alabastrem,

pekným flajstrem,

majeránem,

fundamentem

založila jisté

serdce, amen.
Illatos levendula,

rozmaringhoz hasonló,

add, Isten, hogy én is megvárjam öt,

s megvárva öt testemet vele körülrakjam,

alabástrommal,

szép tapasszal,

majoránnával,

fundámentumra

rakta biztos

szivemet, ámen

A versek átfogó elemzése nélkül is megállapítható, hogy az idézett helyek tropológiai felépítettsége kevéssé strukturált, mint a magyar nyelvü példákban. Retorikai erejük jobbára a sublimis képek enumerációjából árad. Eckhardt Sándor az efféle jelenségeket részint a középkori himnuszok, részint a Catullust imitáló humanista poézis, részint a közköltészet hagyományából eredezteti, és azokat úgy írja le, mint amelyeknek elsődleges funkciója nem az ábrázolás, hanem a magasztalás, ezért e szövegeket elsősorban a climax alakzata szervezi. ${ }^{141}$ Nos, a jelek szerint ez az eljárás nemcsak a spirituális rajongás, de a testi vágy kifejezésére is kiválóan alkalmas. ${ }^{142}$ A szlovák citátumok azt mindenesetre meggyőzően bizonyítják, hogy az alabástrom motívumának alkalmazása a tárgyalt versben nem feltételezi direkt Balassi életművének beható ismeretét, lehet az tágabb (akár areális) kölcsönhatás eredménye is.

\footnotetext{
${ }^{139}$ Uo., 170, 171. A szlovák verseket Sziklay László fordította.

${ }^{140}$ Uo., 188., 189.

141 ECKHARDT Sándor, A régi magyar költők képei = E. S., Balassi-tanulmányok, Bp., Akadémiai, 1972 (Irodalomtörténeti könyvtár, 27), 311-313.

142 Ahogy egy, a Weszprémi-kódexbe illesztett papírszalagon is a következő jelzőfüzér olvasható: szüvem, lölköm, virágom, cinegém ill. aranyom, gombom, ágom, levelem. Vö. HORVÁTH János, A magyar irodalmi müveltség kezdetei = H. J. Irodalomtörténeti munkái, kiad. KOROMPAY H. János, KOROMPAY Klára, I, Bp., Osiris, 2005 (Osiris Klasszikusok), 571.
} 
A tárgyalt strófa folytatásából viszont már Bóta László is evidensnek véli Balassi befolyását (6-7. sorok): ${ }^{143}$

Szerelme elmémben oly forgó, mint malom,

Örlésének kínját mert elmémben vallom...

Meglátása szerint a fenti sorokat a Célia-ciklus ötödik darabja inspirálhatta:

1. Mely csuda gyötrelem ez, hogy a szerelem búmra most malommá tett,

Hol mint gabonáját, engemet, szolgáját szép Céliával örlet,

Siralmam patakja az kereket hajtja, kin lisztté létig töret.

A két szöveghelyet összevetve szembetünő az utóbbi metaforikájának allegóriába hajló, az erőltetett petrarkizálás eredményének is tudható kidolgozottsága. ${ }^{144}$ Ahhoz képest az ismeretlen szerző valóban nem törekszik túlzottan a tropológiai koherenciára: jóllehet a tárgyalt vers második strófájában ritkán alkalmazott képeket vonultat föl, de azok egymás mellé helyezését a fonetikai összeillésen kívül más tényező nem indokolja. A hígulástól viszont nem tünik teljesen függetlennek a két költemény eltérő argumentációs stratégiája sem. A Bírja bár akárki... kezdetüben az ötödik Célia-verssel szemben a cél elérését nem kizárólag az elocutio demonstratív ereje szolgálja, hanem a bemutatást egy adott ponton (az ének nyolcadik sorától) felváltja a suasio (8. sor):

Méltán azért neki magamot ajánlom.

A vers második fele a kívánalmak áradatán keresztül tulajdonképpen a Balassi által többször is kidolgozott elgondolást, a szerelmes férfi alávetettségének státuszait (rab és szolga), ill. az azokban rejlő lehetőségeket ismerteti részletesen. Az alapvető különbség a kettő között abban ragadható meg, hogy amíg a rab egyetlen öröme maga a szolgálat, addig a szolga részesül valamiféle (szerelmi) viszonzásban is. ${ }^{145}$

3. Éljen de ne úgy, hogy csak verjen s kínozzon,

De hogy sok kínomnak könnyebbséget hozzon,

Kötözött voltombúl már ki is oldozzon,

És szerelme útán tágan is hordozzon.

\footnotetext{
${ }^{143}$ BÓTA, i. m. 15.

${ }^{144}$ ECKHARDT, $i . m .322$.

${ }^{145}$ Vö. VADAI István, ,Forr gerjedt elmémre, mint hangyafészekre, sok új vers...”: Balassi Bálint saját kezü versfüzéréröl = V. I., Tükörben tükrözödő tükör: Müértelmezések, Szeged, Tiszatáj, 2002, 18.
} 
Igazság szerint már az előző strófa rímbokrának második fele (vallom, ajánlom) is párhuzamba állítható a Rimay-életmüvel (Enyhits meg, Úristen..., 4. vsz. ${ }^{146}$ ), de az utóbb idézett sorok még tovább erősítik az allúzió érzetét. A 'kínoz' ige fenti alakjának rímfelelői közül kettőt ugyanis Rimay is kijátszik - jóllehet különböző énekekben. A kínoz/hordoz rímpár a Bocsásd Szent Lelkedet... és a Csudálható nagy dolog... kezdetü alkotásokban, a kínoz/hoz pedig a Balassa kódex sorrendjében első szerelmes versében (Szólítván nevemen...) jelenik meg. ${ }^{147}$

Visszatérve a megkezdett gondolatmenethez: Kiss Farkas Gábor mutatta ki, hogy a fenti koncepció első ismert forrása történetesen Aeneas Sylvius Piccolomini egy latin nyelvü novellája, melynek magyar nyelvü fordítása Eurialusnak és Lucretiának szép históriája címen vált ismertté. ${ }^{148}$ Ismertette annak módozatait is: ezek szerint a beszélő kérheti lefokozását (vö. Az erdéli asszony kezéről c. zárlatával: „Legyek ferge rabja, bátor ne szolgája, csak szinte el ne vessen!'”), de előléptetését is. ${ }^{149}$ A tárgyalt ének alanya jellemző módon (hasonlóan a verscsoport többi udvarló darabjához) minden eszközével ez utóbbin fáradozik.

Ez az elkülönülés Balassinál azonban nemcsak a lírai életmüben érhető tetten, de a Szép magyar komédiában is megjelenik. Jelen esetben leginkább az a passzus kívánkozik ide, melyben Sylvanus a fenti strófához hasonló metaforaképzéssel írja le maga és kegyese állapotát: „Ím, minket is együvé köte az Szerelem fölbomolhatatlan kötelességgel, mely kötelességünk, igaz, hogy azelött megtágult volt, de azért fel nem bomlott, fel nem szakadott soha az csomója!" (Actus V. Scena V. ${ }^{150}$ ) Ennek értelmében a legföbb rossz, ami a szerelmessel történhet, hogy nem tartanak igényt szolgálataira; elutasítják, vagy éppenséggel emancipálják. A szerelmi kötelék egészen nem bomolhat fel - a beszélő emitt is azért könyörög mindössze a befejezésben, hogy amennyire lehet, jutalmazzák; ergo hosszabbítsák meg a pórázát.

4. Adjon szabadságot, hogy én szerethessem,

És szolgálatommal kedvit nevelhessem,

Engedje, szép nyakát hogy én ölelhessem,

\footnotetext{
146 RÖM, 35. sz.

${ }^{147}$ RÖM, 1/I. sz., 9. vsz.; 1/VII. sz., 11. vsz.; 9. sz., 10. vsz.

148 KISS Farkas Gábor, Rab és szolga = Ghesaurus: Tanulmányok Szentmártoni Szabó Géza hatvanadik születésnapjára, szerk. CSÖRSz Rumen István, Bp., rec.iti, 2010, 309-315.

${ }^{149}$ Uo., 309-310. Abban, hogy a különbségtétel az említett müveken (ideértve Piccolomini írásait is) nem vonul következetesen végig, Kiss Farkas Gábor a trubadúrok és az őket követő petrarkisták hatását sejti, lévén azok szerelemfelfogása az ilyesfajta elörelépést (eleve a kölcsönösséget) nem engedi meg. E kétféle hagyományhoz, ahogy azt Pap Balázs idézett tanulmányában kimutatja, társulni látszik egy harmadik, kevéssé gáláns is: a Morgai Kata nevére írott versben (Mondják jövendölők bizonnyal énnékem...) a szerelem istennőjének szolgáló beszélő fizetsége a címzettel azonosítható rabnő. (Vö. PAP, Az akrosztichonok és az első harminchárom, 50.)

${ }^{150}$ MIŠIANIK, ECKHARDT, KLANICZAY Tibor, i. m., 105.
} 
E részleges liberatio befejezése nem egyéni invenció gyümölcse, a szerelem egyszerre édes és keserü volta antik mintákra vezethető vissza: egy, a mel (méz) és fel (epe) elegyültségét tárgyaló (jóllehet, nem éppen klasszikus) latin nyelvű négysoros szintén éppen a MadáchRimay-kódexekben maradt fenn. ${ }^{151}$ Az alakzat jóhangzása magyar nyelvre legfeljebb alliterációként (méz és méreg) ültethető át, de ebben a formában is kedvelt fordulat lesz; alkalmazza a Pataki Névtelen, Balassi Bálint és Rimay János is, majd egyre apróbb madarak tollán kopik tovább. ${ }^{152}$ Bóta László ismert álláspontjának alátámasztására tételesen felsorolja azokat a Balassi- és Rimay-szövegrészeket, melyek további stiláris jegyekkel (a gondosan szerkesztett alliterációk és a korban már-már keresettnek tudott ragozott melléknévi igenevek) kiegészülve erre a forrásvidékre, végső soron Rimay szerzőségére utalhatnak. ${ }^{153}$ Ebből az alábbi tanulságok nyerhetők ki.

Hiteles írásai tükrében Rimay jóval szkeptikusabbnak tűnik annál, hogy ehhez hasonló peroratióval rukkoljon elő. Nála a méreg elrejtésére való méz a csalóka látszat és a rosszízü valóság metaforája (Mit jegyez ez a kép..., 23. vsz.), az élet örömeinek és kínjainak aránytalanságát pedig éppen az elhalt Balassi példája bizonyítja (Elogium, 7. vsz.) - vagyis azé a költőelődé, aki a szerelem keserédességét maga is oly gyakran hangoztatta, tkp. anticipatióra számot tartó evidenciává avatta; vö. Szólítván nevemen ..., 2. vsz. ${ }^{154}$ Ugyanakkor Balassi hozzáállása a szerelem e kettős természetéhez is meglehetősen ambivalens. Versei közt olyat is találni (Julia két szemem... ${ }^{155}$ ), mely a tárgyalt énekhez hasonlóan a szerelmet alapvetően édesnek írja le, melyet elsősorban hölgyének kegyetlensége tud megkeseríteni:

10. Dolga mind egyenlö, Szerelemmel egy ö, csak erkölcse különböz,

Kegyes a Szerelem, s Julia kegyetlen, engem halálra üldöz,

Szerelem mely édes, Julia oly mérges, mert engem csak ver földhöz.

Máshol a szeretője sem nélkülözi e tulajdonságot, mely igen gyakran a szájához köthető: mézízü szavaihoz ill. (perifrasztikusan megfogalmazott) csókjához - ez utóbbi esetében talán

\footnotetext{
${ }^{151}$ Madách-Rimay-kódexek, I, 69. A vonatkozó sor a negyedik: „Nil unquam homini mel sine felle datur. ” Pirnát Antal meggyőzően zárja ki Rimay szerzőségét, s a verset Madách Gáspárnak perli vissza. (Vö. PIRNÁT Antal, Rimay János: $A z$ Úr engem sanyaríta, = Klaniczay-emlékkönyv, 265.) A bizonytalan latinos Madách szerelemellenessége ismeretében azonban talán mégis jobb lenne ezt is ismeretlen szerző munkájaként elkönyvelni.

${ }^{152}$ Vö. a Régi Magyar Költők Tára közköltészeti versanyagával.

${ }^{153}$ BÓTA, i. m., 13, 19-21.

${ }^{154}$ Vö. BALÁZS-HAJdU, JANKOVITS, PAP, i. m., 23.

${ }^{155}$ BÖM, 58. sz.
} 
azért dúsulhat föl a jellegzetesen metonimikus jelölés, mert az éppenséggel betű szerint is értelmezhető lehet. ${ }^{156}$

Kiss Farkas Gábor idézett tanulmányában kiemeli Balassi azon énekét, melyben a szerelmi viszonzás csók formájában konkretizálódik. ${ }^{157}$ Hihetőleg a tárgyalt ének beszélője is erre törekszik. A mézszedés v. mézevés ebbéli jelentése nyilván más szerelmi költemények esetében is feltehető, pontosabban: azokban sem zárható ki. Ugyanakkor sem a Pataki Névtelen, sem Rimay János, sem a közköltészet ismeretlen szerzői rabság és szolgaság distinkcióját nem kombinálja azzal a közhellyel, hogy a viszonzatlan szerelem keserü, a beteljesült szerelem pedig édes - e kettő Balassinál is csak az életmü tágabb egységén belül kapcsolható össze. A tárgyalt udvarló vers argumentációja ezekhez mérten igen céltudatosnak mondható. A boldogság nem a szerencsétől, istenektől, egyéb felső erőtől v. külső körülménytől függ: csak és kizárólag a kegyesen múlik, édessé teszi-e a szerelmet azzal, hogy csókra nyújtja ajkát.

\section{Összefoglalás}

A Bírja bár akárki... kezdetű ének beszélőjének aspirációi jobbára a testiségre korlátozódnak, s vágyainak kielégítését a diszkurzív szokásrendnek megfelelően szerelmi szolgálatai fejében kéri. Frazeológiája ezért szükségképpen az udvari költészetére kíván hasonlítani. A kérdés, hogy az ismeretlen szerző éppen Balassi írásait forgatta-e, vagy esetleg a szlovák nyelvü közköltészetből vett át bizonyos szóképeket, motívumokat v. fordulatokat, megválaszolhatatlan, de az jól látszik, hogy tudatosan alkalmazza azokat, hiszen a kívánt eredményt - ellentétben a közköltészet általános gyakorlatával - nem egyszerúen az arisztokratikus regiszter markereinek referálásától várja, hanem egy önálló, főként figuratív toposzokra támaszkodó érvrendszer felállításával kívánja elérni.

\footnotetext{
${ }^{156}$ Vö. Reménségem nincs már nékem..., 5. vsz.; Az én szerelmesem..., 9. vsz.; Méznél édesb szép szók..., 1. vsz.; Ez világgal bíró..., 3. vsz.; Kegyes vidám szemü..., 3. vsz.; Én édes szerelmem..., 3. vsz.; Az Zsuzsánna egy szép német leán ..., 2. vsz.; Vitézek karjokkal..., 7. vsz.

${ }^{157}$ Nö az én örömem..., 4. vsz. KISS, i. m., 309.
} 


\section{Szerelemtül csak kár, hogy tiltunk szép személt...}

$\mathrm{Az}$ ének négy strófából áll, izorímes, négysoros felező tizenkettesekben íródott. ${ }^{158} \mathrm{~A}$ szövegegyüttes azon darabjai közé tartozik, melyek valamilyen erkölcsi minta követésének helyességéről kívánják meggyőzni közönségüket (genus ethicum); csakhogy e tartalom szellemisége szöges ellentétben áll mindazzal, amit a moralizáló költemények általában képviselnek, lévén a jó, melynek elérésére az ének beszélője igen vehemensen törekszik, furcsa módon a szerelmi szabadosság megörzése (conservatio) volna. A szakirodalom azonban csak a szöveg latrikánus minőségét ismerteti, a mü kétségtelen (s hozzá több rétegü) parodisztikus voltát nem említi. ${ }^{159}$ Már Ferenczi Zoltán - még Rimayénak tudva azt felismeri benne az ovidiusi mintát, s párba állítja a Lydia-versek hetedik darabjával, a Valjon $s$ de mi haszon... kezdetüvel, mely kolofónjában jelöli is az elődszöveget: Ovidius Ars amatoria c. alkotását: ${ }^{160}$

6. Venus együtt járván, fiával sétálván ez tanácsot végezé,

Felei közt hinte, szerelmihez inte, s mellyekben beszegezé,

Mint ezt ő könyvében versi közt bévebben Ovidius feljegyzé.

Később Bóta László figyel föl a tárgyalt versben egy másik, az értelmezés szempontjából releváns Rimay-párhuzamra: a két kidolgozásban (Encomia virtutum ill. Encomia et effecta virtutum címen) is fennmaradt morális versezet egy szinte szóról szóra megegyező hasonlatára. ${ }^{161}$ Látható tehát, hogy a két rokonítható Rimay-vers közül előbbi az inventio, utóbbi az elocutio imitációja örvén került a diszkurzusba; s bár e kettőt lehetetlenség szigorúan különválasztva tárgyalni, e tagolást a magam számára sorvezetőként mégis megtartom.

Azt feltehetőleg az Ars amatoria c. tanköltemény-paródia ismerete nélkül is köztudomású lehetett a kor bármely verselője számára, hogy a szerelmes énekek főként (a klasszikus retorikából ismert lélektani okok analógiájára) a szerelem felébresztéséről, megszerzéséről és

\footnotetext{
${ }^{158}$ Kritikai kiadása: RMKT XVII/12, 47. sz.

${ }^{159}$ Vö. TARNAI Andor, A parodia a XVI-XVIII. századi Magyarországon, ItK, 1990, 444-469.

${ }^{160}$ Vö. FERENCZI, i. m., 120.

${ }^{161}$ Vö. BÓTA, i. m., 13.
} 
megőrzéséröl adnak számot, s hogy a beteljesedést mindkettőben a használat (usus) jelenti akárcsak a Rimay által feldolgozott sorokban: ${ }^{162}$

\author{
Halljátok szavaim, mik töle valók, ti leányok! \\ Itt az igaz forrás, merjetek égi tudást! \\ Jön majd, tudjátok már most, jön a zsémbes öregség. \\ El ne feledjétek, múlik a tétlen idö. \\ Míg lehet, és mig itt a tavasz, szép ifju leányok, \\ játsszatok; elfut a lét, fürge folyó vizeként. \\ Már ha alább úszott, nem fordul vissza a hullám, \\ már ha az óra letelt, vissza hiába hivod. \\ Míg fiatal vagy, örülj! Gyors lábbal futnak az évek, \\ mind kevesebb az öröm, fogy, fogy a kezdeti jó. \\ $[\cdots]$ \\ Íme az istennők példája, okulj, te halandó! \\ Csókod meg ne tagadd, nö, ha a férfi kiván. \\ Mit veszitesz, ha becsap? Semmit. Megy minden, ahogy ment. \\ Nem vész el semmid, bárha ezerszer ölelsz. \\ Elrozsdáll az acél, kovakö sincs, mely le ne kopna; \\ téged az édes csók nem kicsinyit, sose félj. \\ Fáklyát fáklyáról hogy gyújtsunk, tiltja-e bárki? \\ Téres tengernek, mondd, ki vigyázza vizét? \\ Mégis, némely lány a fiúnak ,"Most ne!" - kiáltja, \\ bár - egy mosdással több - nem is oly nagy az ár.
}

Cytherea tanításának lényege tehát az, hogy a szerelmi játékokat fiatalkorban érdemes intenzíven űzni. Rimay beszélöje az említett záró strófában szintén a szerelem istennőjének szószólójaként tünteti fel magát ${ }^{163}$ (vagyis a rábeszélést az ethopoeia alakzatába ágyazza), ám mégsem egészen a fentieket hirdeti:

1. Valjon s de mi haszon, ha mely ékes asszony szépségét úgy kémélli,

Hogy minden ő hasznát, kit szép termete ád, csak egy dög férje éli?

Minden az a kedves, azki ha tétetes, javát mással is közli.

2. Rózsa miért kedves? Mert illattal büves, szaggal sokakot táplál,

Így az a jó kegyes, azkinek sok nemes iffjú legény udvart áll,

Mit árt azok közül, ha ki melléje dül, neki kedvére szolgál?

E rescriptio annyiban követi az elődszöveg argumentációs technikáját, hogy elöszeretettel használ példákat (hasonlókat és nem hasonlókat egyaránt) a fentiekben, s a következőkben is:

\footnotetext{
${ }^{162}$ Publius Ovidius NASO, A szerelem müvészete, A szerelem orvosságai, ford. BedE Anna, SZATHMÁRY Lajos, Európa-Helikon, 1982, 57-58. (III. könyv, 57-66. ill. 87-96. sorok.)

${ }^{163}$ Nem egészen helytálló ezért Eckhardt azon megállapítása, mely szerint a Rimay-verssel szemben „nem Vénusz, hanem maga Ovidius leckézteti a nöket." RÖM, 189.
} 
3. Mint meggyúlt gyertyának, ragyagó langjának nem fogy azzal világa, Ha több gyertyát gerjeszt s mindenekben ébreszt szép fént ö égö lángja, Így nem fogy kegyes is, ha sokakra kel is szépséginek virágja.

4. Vasérc megváslódik, ruha szakad, kopik, mihent viselésre jut, Föld hasad, repedez, közel vagyon melyhez járó, nagy országos út, Kegyes megáll éppen, fogyhatatlanképpen, mert kimerhetetlen kút.

5. Bár hát minden eszes, szépen termett kegyes ömagát megkémélje, Iffjak barátságát, éltek nyájasságát szabadságosan élje, Sok csók szép szók között, kit ezekkel közlött, megfogyását ne vélje.

Feltünő különbsége azonban a személyi érvelésben mutatkozik meg, tekintve hogy a benne foglaltak szerint a kicsapongást nemcsak a megfelelö életkor (aetas) teheti indokolttá, hanem az előkelő származás, valamint a családi állapot (conditio) is. Mindez az amour courtois erősen szimplifikált - ebből adódóan komolyan alig vehető - felfogásaként tételeződik, amit az ábrázolt tárgyiasságok, a terminológia, és valamelyest talán a versforma is megerösítenek. Nem árt észrevenni: a ciklus következő darabja (Venus, fajtalan hús...) rögtön le is tiltja az efféle bujtogatást, méghozzá nem a lebeszélés (dissuasio), hanem egyenesen a vádolás (accusatio) eszközeivel. ${ }^{164}$

Rátérve immár a tárgyalt versre: az első szembeötlő eltérés a Rimay-vershez képest, hogy míg előbbi hölgyközönséghez intézte a szavait, ez kizárólag férfitársaival tanácskozik:

1. Szerelemtül csak kár, hogy tiltunk szép személt,

Hajlandóság nélkül mert soha egy sem élt, Jupiter is szépnek tilalmat adni félt,

Söt kedvezni nekik tiszti szerint is vélt.

Vagyis a szebbik nemet a (testi) szerelemtől tiltani hasztalan, mert az természete szerint könnyen kapható arra. A személyi érvek közül a sexus és az animi natura (a közönség számára nyilván elfogadható) egybeolvasztása merőben patriarchális attitüdről árulkodik: magában foglalja, hogy e tiltás férfiakra nem vonatkozik, viszont a törvényt azoknak áll jogában betartatni. Ámde azt is előrevetíti, hogy a „kár, hogy tiltunk” frazéma a cselekvés hiábavalóságánál kézzelfoghatóbb veszteségre utal. Az argumentatio művészi eszközeivel operáló beszélő ugyanis egy müvészeten kívüli bizonyítékot látszik ignorálni, mégpedig a hatodik parancsolatot, $\mathrm{s}$ éppen ezért pogány istenek példájára hivatkozik. A brevitas

\footnotetext{
${ }^{164}$ Vö. JANKOVITS László, Rimay és a civakodó istenasszonyok = Mesterek és tanítványok: Tanulmányok a bölcsészettudományok területéröl, szerk. BöHM Gábor, FEDELES Tamás, Pécs, PTE BTK Tudományos Diákköri Tanácsa, 2014, 204-205.
} 
meglehetősen elnagyoltnak tünik ahhoz, hogy az antik mitológia egy konkrét eseményét idézze föl, inkább arra lehet gondolni, hogy Jupiter ezúttal mint a négy sarkalatos erény közül az igazságosság (iustitia) megtestesítője válik tekintélyérvvé.

Korábban említettem már, hogy a verscsoport attribuálási kísérletei során az egy szótagos rímek alkalmazását általában mint Rimayra jellemző virtuozitást szokás elkönyvelni. ${ }^{165} \mathrm{~A}$ fenti rímbokor azonban újfent a kivételt erősíti: annak rímszavai közül hármat már Balassi is alkalmazott a 42. zsoltár parafrázisában is (Mint az szomjú szarvas...):

7. De te mindazáltal, szomjú lelkem, ne félj, Söt régi Uradban minden ellen remélj, Bízván kegyelmében, higgy, és csendesen élj, Gonoszt hozzá ne vélj.

Illetve mind a négyet a Célia-ciklus keresett technikájú tizedik versében (Szít Zsuzsánna tüzet...):

4. Kártyát játszván velem, vet szivet tromfomra, Kit az bölcs szerelem így magyaráz jómra, Mondván: Ne félj, söt vígan élj, mert tiéd az szép személy, Veres levél tromfodra kél, csak azért, hogy jót reménlj, Semmi gonoszt te ne vélj!

A rímek elkölcsönzésén túl a szövegek között mélyebb imitatív viszony nem mutatható ki. Merőben más a helyzet a beszélő motivációját világossá tevő második strófa esetében:

6. Ajánlatja magát magával az szépség, Az ö ragyagása szivemben ugyan ég,

A strófa kapcsán Varga Imre mutat rá, hogy e tövet melléknévi igenévként képezve Rimay ragyagó, Madách pedig ragyadó alakban használja jelzőként. ${ }^{166}$ (Ez a tény a Balassa János éneke esetében például értelemszerüen Madách szerzősége mellett, míg a tárgyalt ének esetében az ellen szólna.) Bóta régebbi - fent említett - megfigyelése pedig az, hogy a versszak második felében szintén Rimayt idéző alakzatokat lehet felismerni: ${ }^{167}$

Úgy visel bennünket, mint lovat zablás fék,

\footnotetext{
${ }^{165}$ Vö. Во́TA, i. m., 22.

${ }^{166}$ Vö. RMKT XVII/12, 734. A konkrét példák Rimaynál: „Hogy így vöd el éltem ragyagó villámát”, RÖM, 1/V. sz., 9. sor; „,Mint meggyúlt gyertyának, ragyagó lángjának nem fogy azzal világa”, RÖM, 17. sz., 7 sor; „Ragyagó szálkák is körül burítonak”, RÖM, 67. sz., 189-190. sor; , Kit körül környékez ragyagó fényesség”, RÖM, 20. sz., 2. sor. Madáchnál: „Az napnak ragyadó voltát”, RMKT XVII/12, 5. sz., 17. sor; „Ragyadó szerelme szivemben férkezik", RMKT XVII/12, 41. sz., 12. sor.

${ }^{167}$ BÓTA, i. m., 12.
} 
Bóta szó nélkül hagyja a nyolcadik sorban megjelenő, a versfaragó leleményességét fitogtató reduplikált paranomáziát, mint Rimay modorában koholt nyelvi bravúrt, csak azt emeli ki, hogy a (szintúgy egy szótagos) rímszavak és a hetedik sor hasonlata megtalálhatóak a költő azon versében, melynek rövidebb variánsát az Istenes énekek kiadásai örizték meg (Virtus, lelki jószág...), a hosszabb pedig a Madách-Rimay-kódexekben maradt ránk (Itt egy asztalt látunk...). Előbbinek 17., utóbbinak 47. strófájáról van szó:

\section{Kövessen engemet az Szemérmetesség, \\ Ki minden dolgunkban ékesitő szépség, \\ Fertelmességünkben ezáltal lehet vég, \\ Ha ez vezet minket, mint lovat zablás fék.}

Bóta ezúttal is mennyiségi érveket hoz Rimay szerzősége mellett: kimutatja, hogy amíg a zablás fék kifejezés a költő kedvelt fordulata, addig annak unokaöccse a fék helyett mindig a régiesebb fékemlő alakot használja. ${ }^{168}$ Az etimológiai vizsgálódásokat annyival egészíteném ki, hogy a visel szó a XVII. század elejéig vezet jelentésben is adatolható, vagyis a hasonlat lényegében ugyanaz, de a hasonlított tagok egymás antonímiái. ${ }^{169}$

A kora újkori felfogás számára - ahogy azt a 17. századi moralizáló költészetünk is híven tükrözi ${ }^{170}$ - magától értetődik a szemérmetesség és a szépség azonosítása, vagyis egy dolog esztétikai minőségének függővé tétele annak erkölcsi értékétől. A Szerelemtül csak kár... kezdetü ének beszélője azonban másként közelíti meg a kérdést: ami látszatra szép, az attól éppenséggel lehet bünös is. Csakhogy amíg a szemérmesség megőrzését a kényszerítő zabolázáshoz hasonlítani teljesen evidens elgondolás, addig a féktelen kicsapongás és a zablás fék csak mint oxymoron kapcsolható össze. Az ösztön szava ezúttal erősebb törvény, mint az isteni parancsolat; vagyis a világ rendje fenekestül felfordul. S ha hozzávesszük az itt látott személyi érvek (sexus, aetas, conditio) radikális különbözőségét az előzőekben bemutatott Ovidius-passzus, ill. az azt parafrazáló Rimay-ének praxisától, értelmezhetjük mindezt a bahtyini karnevál-koncepciónak megfelelően is: a hatalmat gyakorló vének alul maradnak a telhetetlen szépnemüekkel szemben. ${ }^{171} \mathrm{~A}$ világtudás azonban az idősebb urak szexuális érdeklődését a fiatal hölgyek iránt mégis életszerübbnek sejteti, mint utóbbiak általános gerontofil irányultságát, ezért azt is lehet gondolni, hogy ezt a modellt esetleg valamiféle ki

\footnotetext{
${ }^{168}$ Uo.

${ }^{169}$ Vö. a történeti-etimológiai szótár vonatkozó címszavával. A magyar nyelv történeti-etimológiai szótára, III, föszerk. BENKŐ Lóránd, Bp., Akadémiai, 1976 [a továbbiakban: TESz], 1156.

${ }^{170}$ A kérdésről bővebben ld. az appendixet (A Rimay-örökség Madách Gáspár tollán).

171 Vö. Mihail BAHTYIN, François Rabelais müvészete: A középkor és a reneszánsz népi kultúrája, ford. KÖNCZÖL Csaba, Bp., Osiris, 2002 (Sapientia Humana), 258-261.
} 
nem mondott érdek hívta életre, amit a harmadik versszakban megmutatkozó érvmenet is alátámasztani látszik:

5. Holt az, nem eleven, ki szépet nem szeret, Karján kettévágják bár annak az eret, De azki fogával rághat még kenyeret, Személitöl kapott jobb kedvet el nem vet.

Meggyőző példát találni (szemben Ovidius v. Rimay verziójával) ehhez az ügyhöz bajosan lehet, ezért a beszélő az egymást kizáró minőségek toposzával igyekszik legitimálni álláspontját. Tetejébe e részlet rejtetten azt is sugallja, hogy aki nem érez a beszélővel, az meghalt; holtakkal pedig aligha kell számolni a döntéshozásban. Azonban ez a megközelítés sem változtat azon a tényen, mely szerint a tárgyalt ének a nevettetésen kívül aligha való másra.

Bóta e strófából a kenyér-metaforát emeli ki, mint Rimay jellegzetes képalkotó eszközét és rímszavát. Ennek egy-egy előfordulását ismerteti a Balassi- és Madáchversanyagból is, de - mint írja - annál többször csak Rimay írásaiban jelenik meg. Anélkül, hogy attribúciós kérdésekben állást kívánnék foglalni az említett költők bármelyikének javára, úgy gondolom, ez meglehetősen faramuci érv egy szerzőséget firtató dolgozatban. Ráadásul a citált sorok mind a Balassi- (,Eledelemet is kérdé, ha kenyér-é?",172), mind a Madách-vers (,Hogy keserü bánattal kenyeret ne egyél...”173) esetében metaforikusak, értelmük nagyon hasonlít, és nem mellesleg a Szerelemtül csak kár... kezdetü ének vonatkozó passzusáétól sem esik messze.

Már az eddigiekből is kitünt, hogy a tárgyalt vers kifejezésbeli eszközkészlete merőben különbözik a Valjon s de mi haszon ... udvarias hangvételétől. A latrikánus jelzőt sem pusztán szellemiségével érdemelte ki, hanem illusztratív konklúziójának egyértelműen pornográf trópusaival:

6. Szépek szabadságát hagyjuk ezért helyin, $S$ vigadjon, ki öket viselheti nyelin, S nyugodjék is ki-ki kegyesének mellin, S kitöl lehet, kést is cseréljen hüvelin.

\footnotetext{
${ }^{172}$ BÖM, 53. sz. (Kérde egy barátom ...), 9. sor.

${ }^{173}$ RMKT XVII/12, 27. sz, 3. sor. Az idézet felelő sora (,S halálhozó helyére hogy ne heveredjél”) ismeretében nem tartható Bóta azon megállapítása, mely szerint ,az alliterációt [...] Madách Gáspár moralizáló paraszti múzsája nem ismeri, egyetlen egyet nem találunk nála.” ВÓTA, i. m., 20-21.
} 
Ahogy arra Varga Imre rámutat, a Madách-életmü több e csattanós zárlattal parallel szöveghelyet tartogat. ${ }^{174}$ Az egyik ilyen a Madách-Rimay-kódexek II. kötetének 6. füzetében található, paráznaságról írott traktátus egy betétverse. A kritikai kiadás jegyzetapparátusában Varga meggyőző érveket hoz amellett, hogy Madách vélhetőleg fordítója lehetett az eredetileg nagy lélegzetü, feltételezhetően cseh nyelvü, de mindmáig azonosítatlan munkának, melyet a jelek szerint teljes egészében talán nem is dolgozott fel, s ami elkészült, az is csonkultan maradt ránk. Madách jellegzetes munkamódszerét mutatja ugyanis, hogy a szöveg hemzseg az elírásoktól, ami arra utal, hogy egy korábbi piszkozatát másolta a füzetbe, s hogy azon aztán - erre utalnak a javítgatásai - további változtatásokat látott szükségesnek eszközölni. Szerzőségét a müben fellelhető latin versbetétek sokfélesége zárja ki. Végül a népnyelvü (Madách kompetenciáit tekintve: cseh) forrásra szintén a latin versikék beillesztése utal; lévén azokat eredetiben is odamásolja, s csak azután közli (az eredetitől gyakran igen elrugaszkodott) parafrázisukat. Ahogy tehát a következő, ismeretlen eredetű költemény esetében is: $:^{175}$

\footnotetext{
Mala enim herba: mulier mala,

Sepe enim altum scholasticum, fecit fantasticum,

Abundantem, fecit mendicantem,

Dominum superbum, transmutauit in seruum,

Querit es obulum, grossum et florenum

Non querit, honores, nec tendit ad pudores,

Bilinguis mulier, ac velut, instabilis aer.

Decipit quam plures, velut in nocte fures.
}

Madách a fentieket ekként dolgozza át:

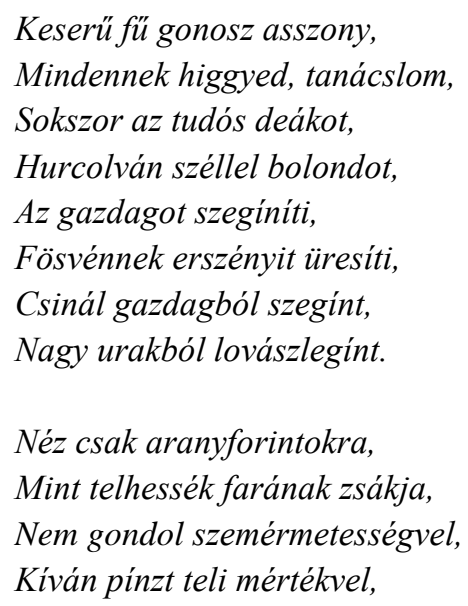

\footnotetext{
${ }^{174}$ VARGA Imre, Tallózások Madách Gáspár körül, 70.

${ }^{175}$ Madách-Rimay-kódexek, II, Rimay János hátrahagyott munkái, 147. A vers kritikai kiadása: RMKT XVII/12, 691. A citátumot a következö forrásból lehet azonosítani: Lexicon Latinitatis Nederlandicae Medii Aevi, Fasc. 29., comp. Johanne W. FuCHS, Leiden. E. J. Brill, 1988.
} 
Messze távozik jó erkölcstül.

Nincs elmélkedés azokrúl,

Mindeniket hiv melléje,

Telhessék eleven késsel hivele.

A másik párhuzamosságot a Bendő Panna komáromi asszony éneke c. csúfoló rejti. A kettő összevetése pedig nemcsak azt az észrevételt támasztja alá, hogy a hiteles Madách-versek nagy részét nettó az alkalmi költészet paneljeinek variációja teszi ki, hanem azt is érzékelteti, hogy azok ezt a fordulatot sohasem a rábeszélés (suasio), hanem mindig a vádolás (accusatio) hangján szólva sütik el: ${ }^{176}$

10. Uradat ha háznál te nem érezed,

Egy mélyföldre ha eleredett,

Mely nem méltó, melléd fekteted,

Csak telhessék nyers börrel hiveled.

A három változat közös tulajdonsága, hogy trópusaik (nyél, kés, nyers bör, hüvely) nem annyira müköltői invenció eredményei, hanem szinte kizárólag tabuszavak helyettesítésére való köznyelvi metaforák, s ez azt is jelenti, hogy elvileg az összecsengő sorok egymástól függetlenül is létrejöhettek volna - ezt a lehetőséget persze kizárja az a tény, hogy mindhármat Madách Gáspár keze örökítette meg.

A keletkezéstörténethez (s azon keresztül bizonyos fokon a szerzőség kérdéséhez) ebben az esetben egyedül a tropológia kínál támpontot. Érdemes megfigyelni ugyanis, hogy a variánsok nem azonos eszközökböl tevődnek össze. A Szerelemtül csak kár... kezdetű vers utolsó sorának eleve áttetsző szóképei (kés és hüvely) az idézett parafrázisban kiegészülnek az eleven epithetonnal, ami még inkább egyértelművé teszi azok jelentését. Az eljárás még inkább szembeötlő a Bendö Panna énekében: a kés metaforát felcserélő a nyers bör metonímia a képalkotásnak még ezt a primitív komplexitását (kés és hüvely) is felszámolja. Kézenfekvő megoldásnak azt tartom ezért, hogy a tárgyalt verset másoló Madáchot megragadta a kép drasztikussága, s ennek okáért azt - a didaktikus szándéknak megfelelően felpuhítva - maga is többször felhasználta.

A kimutatott allúziók a füzet verseinek elemzése során most először az elö- és utóidejüség kérdését is felvetik. A Balassi-reminiszcenciák jelenléte (figyelembe véve a többi körülményt) nem kérdőjelezi meg Balassi elsőségét, ugyanakkor Rimay moralizáló költeményei elvileg keletkezhettek később, mint a tárgyalt latrikánus vers. Ehhez hozzászámítva, hogy az

\footnotetext{
${ }^{176}$ A vers kritikai kiadása: RMKT XVII/12, 40. sz. A kérdésről ld. még: JANKovics, A Madách Gáspárjelenség, 53-54.
} 
igencsak sikamlós mulattató ének alkotója ha szépen kimunkálva is, de - úgy lehet - a maradandóság igénye nélkül hozta létre mủvét, éppenséggel nem zárhatjuk ki (az általunk fiatalkoriként ismertnél is fiatalabb ${ }^{177}$ ) Rimay János szerzőségét sem. Annál, hogy a tudós költő mások tetszetősebbre sikerült képeit plagizálja, mindenesetre valószínübbnek látszik, hogy sajátjait reciklálja későbbi müveiben.

A másik lehetőség érzésem szerint némiképp életszerübbnek tünik. Eszerint Rimay János elöbb megírja a Valjon s de mi haszon... kezdetü éneket, s valamikor ezután valaki (nem zárhatjuk ki, hogy éppen ő maga) elkészíti annak travesztiáját is, s abba (immár az irónia eszközeként) belefoglalja az idézett moralizáló versekböl ismert hasonlatot, valamint Balassi rímszavait is.

\section{Összefoglalás}

A fentiekben tárgyalt vers egy olyan Ovidius-mü (az Ars amatoria) invencióját követi, amely frivolsága okán a 17. századi erkölcsrend szerint aligha lehetett alkalmas direkt értelmü imitációra. Ennek ellenére két, egymáshoz igen közel álló szöveg kölcsönöz (ráadásul nagyon eltérő módon) abból különféle retorikai eszközöket. Rimay János stratégiája a visszavonás (revocatio). A költő Valjon s de mi haszon... kezdetü versében Ovidiushoz képest némi változtatással tolmácsolja a szerelem istennőjének szabados tanácsait, merthogy azok érvényességét kizárólag a nemességre korlátozza; vagyis arra a társadalmi rétegre, amelyik a szerelmi költészet udvari válfajában érdekelt - hogy aztán e vers párdarabjában (Vénusz, fajtalan hús...) máris tagadja az egészet (ahogyan a Remedia amoris is visszavonja az Ars amatoria tanait.)

A Szerelemtül csak kár... szerzője ezzel szemben parodizál. A jelek szerint azonban ez nem elsősorban az ovidiusi forrásra irányul, hiszen arra - szemben Rimayval - még csak utalást sem tesz, mindössze alapszituációját forgatja ki egy igen archaikus (karneváli) mintázatnak megfelelően. És nem is önmagában Rimay rescriptióját, mert akkor a müfaji szabályoknak megfelelően az udvari szerelmi költészetéhez hasonló terminológiával kellene operálnia, márpedig annak szublimáltabb metaforikáját itt egy nagyon is közhasználatú képalkotás váltja föl, mely inkább a moralizáló költészet sajátja.

\footnotetext{
${ }^{177}$ HoRvÁTH Iván, TÓтH Tünde, Rimay ifjúkori versgyüjteményének rekonstrukciója = Ámor, álom és mámor: A szerelem a régi magyar irodalomban és a szerelem ezredéves hazai kultúrtörténete, szerk. SZENTMÁRTONI SzABÓ Géza, Bp., Universitas, 2002, 457-467.
} 
Láttuk, ahogy az ethopoeia felszámolása és a téma inverziója a tárgyalt versben a beszélöre irányítja a figyelmet; akinek - szemben az Ars amatoria ill. a Valjon $s$ de mi haszon... szubjektumával - nemcsak hangja lesz saját, de kirajzolódnak egyes (nevetséges) tulajdonságai és (visszás) motivációja is, s aki e tótágast álló ügyet egyebek mellett egy Rimaytól is ismert figurával szemlélteti, csakhogy azzal ellentétes, összességében pedig paradox jelentésben. Mindent összevetve ezért könnyen elképzelhetőnek tartom azt a lehetőséget, hogy a Szerelemtül csak kár... kezdetü ének nem más, mint egy kissé vaskosra sikerült Rimay-paródia.

Végezetül: általában igaz lehet Gerézdi Rabán a Balassa János éneke kapcsán (Madách Gáspár szerzősége javára) tett észrevétele, mely szerint az ironikus ethopoeia alakzata úgy jellemzi a férficsúfolót, mint az aposztrophé az asszonycsúfolót. ${ }^{178}$ De - tegyük hozzá - az sem példa nélkül való, hogy (éppen) Madách nyíltan kiénekelje férfitársai viselt dolgait (vö. Szodomához hasonló...). Gerézdi megfigyelése voltaképpen tehát nem növeli a tulajdonítás esélyeit sem a Balassa János éneke címü, sem a Szerelemtül csak kár... kezdetü vers esetében, ugyanakkor jól rávilágít ezek figuratív szerkezetének analógiájára. Igen érdekes (mert attól talán nem független), hogy amellett közös bennük a karneváli jelleg is: előbbiben a szereplők identitása nem jut nyugvópontra, utóbbiban össze nem illő alakok képeznek groteszk párt. Az efféle konstrukciók pedig nagyon távol esnek a hiteles Madách-versanyag monotóniájától. Ám ennél a szintén nem perdöntő megfontolásnál talán lényegesebb eredmény azon perspektíva kialakítása, amelyből nézve a Balassa János éneke sólymocskájárúl c. vers mégsem tünik olyan egyedülállónak a régi magyar költészet történetében.

${ }^{178}$ Vö. GERÉZDI, i. m., 691., 693. 


\section{Semmi állat nincsen földön nyomorultabb...}

Az ötstrófás ének elején az ismert okok miatt csonkult. ${ }^{179}$ A félbevágott kezdősor (az őrszót képező első szó kivételével) Radvánszky közléséből egészíthető ki. ${ }^{180}$ Izorímes, metruma négysoros felező tizenkettes. Mint általában a funkcionalitás igényéből készült alkotások, ez a tipikus udvarló vers is kevés gyönyörüséget tartogat, klisészerü fordulatai mindazonáltal jól vannak szerkesztve. Kéttagú diszpozíciója is típusának megszokott sémáját követi: a beszélő az első részben (1-2. vsz.) az egyoldalú szerelem megpróbáltatásait mutatja be, a második részben (3-5. vsz.) kedvesét igyekszik rábeszélni érzelmei viszonzására.

1. Semmi állat nincsen földön nyomorultabb, Szerelem töriben akadott szegény rab, Elméje bujdosik, mihelt felkel az Nap, Éjszaka is szeme semmi álmot nem kap.

Jankovics József korábban idézett tanulmányában a füzetbéli versek összetartozásának zálogát a petrarkista hagyomány követésében, a stilus sublimis kialakításában és az udvarias terminológiában látja, s ebböl arra következtet, hogy azok valamiféle (nem részletezett) fiktív epiko-lírai, és talán kronológiai rendet is követnek, azaz ciklust képeznek. ${ }^{181}$ Csakhogy az eddigi eredmények fényében úgy tünik, hogy az egyes szövegek beszédmódjainak különbözősége ezt a hipotézist nemigen támasztja alá. A fenti szakasz rímszavai ugyanakkor ennek ellenkezőjét - vagyis azt, hogy e gyüjtemény darabjai elvileg keletkezhettek volna egymástól teljesen függetlenül is - megint csak kizárják. Az első ének (Ne gondold, szerelmem...) tárgyalása során kitértem arra, hogy annak kilencedik, záró strófájának rímszavai (napja / apja / kapja / rabja) közül kettővel Balassi is él hatodik Célia-versében (Azmely keresztény hü..., 6. sor):

\section{Ó, szerencsétlen nap, ki elragad és kap attól, ki hiven kedvelt!}

Nem állítom persze, hogy e rímpárt (nap-kap) ne lehetett volna feltalálni Balassi szerelmi költészetének behatóbb ismerete nélkül, de - ahogy azt szintén említettem már - talán mégsem teljesen légből kapott ötlet egy olyan mü hatását feltételezni a háttérben, melynek egyébiránt teljes harmadik strófáját újraírja az együttes tizenkettedik darabja, vagyis a

\footnotetext{
${ }^{179}$ Kritikai kiadása: RMKT XVII/12, 48. sz. A betűhív átiratot modernizáltam.

${ }^{180}$ Vö. RiMAY János Munkái, 25., ill. RÖM, 163.

${ }^{181}$ Vö. JANKOVICS, i. m., 51.
} 
Szerelmesitől vált... kezdetü ének. ${ }^{182}$ Aligha véletlen továbbá, hogy a tárgyalt vers a rímbokrot ugyanazzal a taggal bővíti, mint a Ne gondold, szerelmem... kezdetű ( $r a b)$; már csak azért sem, mert a nap szót viszont - szemben Balassival, aki időegységet ért rajta mindkét szöveg szerzője égitest jelentésben használja. Az elő- ill. utóidejűség és a szerzőség kérdésében azzal együtt pusztán a fentiek alapján ismét csak nem lehet határozottan állást foglalni; a potenciális rímtoposz kidolgozásai származhatnak azonos és különböző szerző(k)től is.

Az álmatlanság motívuma több ízben is megjelenik a füzet anyagában, ezért is érdemes összevetni a korabeli magyar nyelvü szerelmi költészet parallel mintáival. A Pataki Névtelen históriájában (Eurialusnak és Lucretiának szép históriája) például Lucretia ugyan épp nem szenved inszomniától, de gyötrő gondolatai alvás közben is Euralius körül járnak (Quinta pars, 58. vsz. $\left.{ }^{183}\right)$.

De míg élhete is, soha nyugodalma nem lön Lucretiának,

Hanem minden éjjel álmában követé utát Eurialusnak...

E közhelyet Balassi Bálint is többször kidolgozza. A Balassa-kódex rendjét tekintve először az azonosítatlan mintájú tizenhatodik versében (Kikeletkor, jó Pünkösd havában ... ${ }^{184}$ ), mely a latin nyelvü címében (Insomnium extra[hit]) foglaltakon kívül egy álmot beszél el: a fikció szerint a beszélő egy átvirrasztott éjszaka után ágyából kikelve, egy fa alatt lel végre nyugalomra, s ez alatt végre szerelme is beteljesedik.

Már ismert a forrása a huszadik, Somnium proponit c. darabjának (Már csak éjjel hadna... ${ }^{185}$ ), s az Jakob Regnart Wann ich den ganzen Tag geführet hab mein Klag kezdetü éneke, de az ezt felfedező Eckhardt Sándor az eredeti mögött is olaszos galantériát sejt. ${ }^{186} \mathrm{~A}$ Huszadik azonban a Tizenhatodikhoz hasonlóan egy álomleírás; vagyis hőse, ha keveset és rosszul is de mégiscsak tud aludni (1. vsz.):

Már csak éjjel hadna énnékem nyugodnom,

Ha nappal miatta nyughatatlankodom,

De lám, éjjel-nappal érte csak kínlódom,

Gyakran költ álmomból róla való nagy gondom.

\footnotetext{
${ }^{182}$ Ld. a vonatkozó fejezetet.

${ }^{183}$ RMKT 9, 459.

${ }^{184}$ BÖM, 17. sz.

185 BÖM, 13. sZ.

${ }^{186}$ Vö. ECKHARDT, Balassi Bálint irodalmi mintái, 433.
} 
Az ábrázolt jelenség tehát - a beszükült tudatállapotból fakadó nyugtalan álmok - ugyanaz, mint a Pataki Névtelen mủvében, s ezt variálja tovább a töredékesen fennmaradt Harmincadik (Mire most, barátom ... ${ }^{187}$ ) is (27. vsz., 2-3. sor):

Elöttem szüntelen képe, jó termete,

Ha szinte aluszom is, álmodom véle...

Megjegyzem, ez utóbbi vers több, a tárgyalt énekben is megjelenő panelt tartalmaz, mint a szerelmi szolgálat (26. vsz.), az élethosszig tartó szerelem (uo.), a szerelmes és a többi teremtmény viszonya (28. vsz.); csakhogy e tényböl a vaskos közhelyesség okán megint csak nem lehet semmiféle konzekvenciát levonni a kettő viszonyát illetően.

Folytatva a sort: míg az álom motívumát a Pataki Névtelen és Balassi narratív elemként, addig egy kiábrándult hangú versében (Cupido, ne, nyilad...) Rimay János trópussá alakítva alkalmazza (1. vsz.):

Cupido, ne, nyilad, lüj vele bátor mást,

Nem várok én tüled már semmi áldomást,

Jól felébrölt szemem nem kéván álmodást.

Mindezekkel ellentétben a Semmi állat nincsen ... kezdetü ének viszont e toposznak nem azt a szegmensét részletezi, mely szerint a szerelmesek számára elmosódik a reális világ és az álomvilág határa, hanem csupán egyetlen mozzanatot ragad ki abból, s annak hiperbolikus megjelenítésével formálja szánakozást keltővé a külvilágnak alkotott önarcképét.

Közhelyes a második strófa is, amelyben a beszélő a lélek cseréjének koncepcióját szemlélteti saját példáján: ${ }^{188}$

2. Lelke, szive nincsen az maga testiben, Azok tüle mentek mert szeretöjiben, Kételen úgy élni kell annak kedviben, Kinek szive, lelke tartatik keblében.

Majd tanácskozó beszédnemre váltva folytatja a gondolatmenetet, mely ekként végül megint egy lélektani érvben csúcsosodik ki (imminutio):

3. Ne csudálj hát engem te, az én szeretöm, Elég az, hogy nincs te kívöled eröm,

\footnotetext{
${ }^{187}$ BÖM, 19. sz.

${ }^{188}$ Vö. a Balassa-kódex 17. számú Balassi-versével (Csókolván ez minap az én szép szeretőmet...), mely pusztán a lélekcsere-toposz kifejtéséböl épül fel, 1. BÖM, 32. sz. A versszöveg közlésétől terjedelmi okokból tekintettem el.
} 
Lelkemmel, kivel birsz, légy inkább segitöm,

Tudván, hogy te lehetsz kinomban enyhitöm.

A versszak második szavát javítottam, mert a kézirat azt felszólító módban (csudáld) őrizte meg. Varga Imre - aki igen alapos statisztikát állít össze Madách grammatikai sajátosságairól, a ragozási következetlenségek között e hibatípust is megemlítvén ${ }^{189}$ - a hibás alak és a Második c. Rimay-vers kezdősora közötti hasonlóságot teszi szóvá: ${ }^{190}$

Ne csudáld szívemet, hogy illyen keserves...

A „,ne csudáld” fordulatot éppenséggel Rimay más költeményeiben is meg lehet találni. ${ }^{191}$ Varga vélhetőleg azért pont ezt emeli ki, mert úgy találja, hogy a kifejezésbeli párhuzamosságok mellett a két vers "lírai alaphelyzete” is ugyanaz. ${ }^{192}$ Ez utóbbi észrevételével azonban újfent nem tudok egyetérteni. Rimay éneke arról szól, hogy a szerelmesek vonzódása kölcsönös; úgy lehet, jegyben is járnak már, ámde valami külső körülmény miatt ideiglenesen el kellett válniuk egymástól. Ezzel szemben a tárgyalt vers e szituáció komponenseinek egyikét sem tartalmazza. Annál szembetűnőbb az a szóhasználati azonosság, amire elsőként Bóta László mutat rá a tárgyalt ének 4. és Rimay Örülhetne szívem... kezdetű versének 3. strófája között: ${ }^{193}$

\section{4. Ébreszt és éleszt engem az te két szemed, \\ Rólam azért öket, ha lehet, le ne vedd, \\ Söt kedvedet hozzám mindaddéglan neveld, \\ Miglen tölem áldást érdemelhet neved.}

Illetve:

3. Réten, völgyen, hegyen mert ö hol elmegyen, duplált szépség követi,

Vidámb minden virág, azhová lépik, shág, vagy szeme fényét veti,

Mindeneket vidit, ébreszt, éleszt, indit szépségének termeti.

Bóta megalapozottan állítja, hogy az igei állítmányok fokozó halmozása Rimayra jellemző stílusjegy. ${ }^{194}$ Ebböl azonban nem következik feltétlenül, hogy a tárgyalt verset is Rimay János írta volna; mégpedig a következők miatt nem.

Ami a tárgyalt verset illeti, abban a képalkotás több eleme is egybeesik a gyüjtemény első darabjának (Ne gondold, szerelmem...) eszközkészletével, azok felhasználása azonban

\footnotetext{
${ }^{189}$ Vö. RMKT XVII/12, 666-667.

${ }^{190}$ Vö. RMKT XVII/12, 734.

${ }^{191}$ Vö. RÖM, 12. sz. (Mi lelt? Azt kérdhetnéd...), 25. sor; ill. RÖM, 15. sz. (Cupido, ne, nyilad ...), 10. sor.

${ }^{192}$ RMKT XVII/12, Uo.

${ }^{193}$ BÓTA, i. m., 14.

${ }^{194}$ Uo.
} 
eltérő. A szerelem tőre itt nem azonosítódik a kegyes hölgy szemeivel, sőt ez utóbbiak szüntelen figyelme inkább felszabadítólag hat a beszélőre. Vagyis ezek az eszközök szemben azzal, ahogy a Ne gondold, szerelmem... kezdetü énekben megjelenítődtek - itt akár annak a kibocsátáson alapuló látáselméleti modellnek is megfelelhetnek, melynek mibenlétét éppen Rimay fent idézett strófája kapcsán ismerteti Jankovits László. ${ }^{195}$ Ez a szakasz azt írja le, ahogy Lydia szépsége fokról fokra megeleveníti környezetének elemeit, csakhogy - amint azt idézett tanulmányában Jankovits kifejti - ennek metódusa fordított sorrendben ábrázolódik (,,vidit, ébresz, éleszt, indit”), vagyis a gradatio mesterséges rendet (ordo artificiosus) követ. ${ }^{196}$

Bóta Rimay szerzősége mellett hozza föl azt is, hogy a költő más verseiben is kijátszott egy a fentiekkel részben azonos, részben szinonim szavakból álló rímet. Így a Lydia-versek harmadik darabjának (Valjon s de mi haszon ...) 7-8. soraiban:

Mint meggyúlt gyertyának, ragyagó langjának nem fogy azzal világa,

Ha több gyertyát gerjeszt, s mindenekben ébreszt szép fént ő égö lángja ...

Valamint $A z$ Úr az égben... kezdetű éneke 9-14. soraiban: ${ }^{197}$

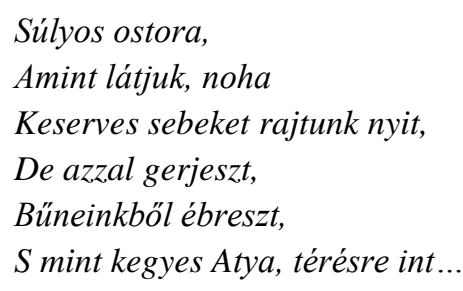

Csakhogy ezekben a többé-kevésbé állandósult igei metaforák csupán egyszerü szinonimái egymásnak, közöttük fokozati különbség nincsen. Nem így a tárgyalt ének kérdéses szókapcsolatának (,,ébreszt és éleszt”) esetében.

Úgy gondolom, kicsi a valószínűsége annak, hogy bármely versszerző előbb megalkot egy két tagból álló alliteráló figurát, majd az eredeti sorrendet megőrizve azokat megtoldja további két elemmel, s e bővítés következtében az eredeti szórendet az ordo artificiosus többletével ruházza fel. Kézenfekvő magyarázatnak ezért azt tartom, hogy ismét egy megírt Rimay-vers valamely mutatós alakzata redukálódik szükség szerint egy alkalmi költeményben.

\footnotetext{
195 JANKOVITS, Rimay János: Örülhetne szivem..., 253. Ld. még a Ne gondold, szerelmem... kezdetű ének tárgyalásánál.

196 Uo.

${ }^{197}$ BóTA, i. m., 14. Bóta László következetesen, így ehelyütt is a kritikai kiadás szövegközlésére támaszkodik, csakhogy Eckhardt a 14. sort hibásan közli, ekként: „S mint kegyes Atya, térésre indít.” (Kiem. tőlem. B. P.) Vö. RÖM, 51. sz.
} 
A versszak második feléből kiviláglik, hogy akárcsak a szövegcsoport negyedik tétele, a Bírja bár akárki... kezdetü ének esetében, az itt képviselt szerelemeszményben is bizonyos feltételekhez van kötve a férfi alávetettsége. ${ }^{198}$ De míg az előbbiben a viszonzásul várt csók metaforákon keresztül jelenítődik meg, a tárgyalt vers záró strófájában ezek az igények nyíltan le vannak írva:

5. Azt akkor nyered meg, ha kedvedben fogadsz, És kiesnem abból életemben nem hagysz, Higgy, hogy hü szolgádra holtodiglan akadsz, Ha szép számnak száddal sok szép csókokat adsz.

A zárlat rímszavai hasonló pozícióban szintén adatolhatók Rimay Jánostól, csakhogy ezúttal is két különböző kidolgozásban. Mivel a korabeli szerelmi költészet meglehetősen kötött szókészlettel operál, ezért talán az tűnne kevésbé véletlenszerünek, ha egyes kifejezések nem kerülnének együtt rímhelyzetbe, s ezek a konstellációk aztán nem ismétlődnének meg más költők életművében - mindenesetre a fogad és az ad ill. a hagy és az ad igék összecsengésére a Végtelen irgalmú... és a Kiáltok hozzád mélységböl... kezdetü énekekben találni példát. ${ }^{199}$ (Azzal a kiegészítéssel, hogy az előbbi együttállás már Balassi Ó, magas kősziklák... kezdetű versében is megfigyelhető. ${ }^{200}$ )

A fenti sorok amúgy egyfajta metapoétikai állásfoglalásként is értelmezhetők, eszerint a szerelmi költészetben az áldás mint beszédnem (laus) egyedül a beteljesült szerelmet hivatott leírni. Vegyük észre, a versben női név semmilyen minőségben nem jelenik meg. S ebből adódóan azt is feltehetjük, hogy bár a habitus corporis tartózkodó felhasználása általános jellemzője a versfüzér udvarló verseinek, jelen esetben a visszafogottság is lehet tudatos - ti. a beszélő kedvesének testéből mindösszesen szemét és száját említi meg úgy, hogy azokat semmiféle ornatus nem övezi. Sőt, különös módon ez utóbbival szemben is inkább a versbéli (férfi) alany szája viseli a szép jelzőt - hozzáteszem, nem esik nehezemre elfogadni Bóta álláspontját, aki a szokatlan elrendezést a sürü alliterációba alkalmasint belezavarodó másoló tévesztésének tulajdonítja. ${ }^{201}$ Továbbmegyek: az egy szótagos

\footnotetext{
198 Ld. a vonatkozó fejezetet.

${ }^{199}$ RÖM, 1/III., 23. vsz.; 42. sz., 6. vsz.

${ }^{200}$ BÖM, 62. sz., 9. vsz.

${ }^{201}$ BÓTA, i. m., 7. Varga Imre a javítást nem fogadja el, s a Bóta által hozott Rimay-párhuzamra (,,Szép szád teljes mézzel, nyelved bölcs beszéddel”; RÖM, 16. sz., 5. sor) az alábbi Rimay-párhuzamot hozza ellenpéldaként: „Szent Isten, adj látnom, orvosoljon bátron, szája édes csókjával.”(RÖM, 11. sz., 18. sor.) Vö. RMKT XVII/12, 735.
} 
melléknevek utalhatnak éppenséggel a pontatlanul reprodukált vers utólagos metrikai kiigazítására is.

Az egymásra halmozott hiperbolák arányozásában szintén mértéktartás tapintható ki. (A nyilvánvaló irracionalitás kerülése önmagában persze nem szünteti meg a szolidan túlzó szerkezetekből kibontakozó logikátlanságokat: érezni némi ellentmondást abban, hogy a beszélőt álmatlanságtól éppen kedvese ébresztő erejű szemeinek lankadatlan figyelme szabadítaná meg.) Az örök szerelem e vers felfogása szerint - ellentétben pl. egyes Balassiversekben taglalt érzelmek eternális voltával - csupán a földi élet végéig tart. Nagy Ferenc idézett dolgozatában vetődik fel a kérdés, hogy ha a hölgyre mért próba szintén e tartam egészére terjed ki, akkor a beszélő mikor és hogyan szándékozik mégis ahhoz magasztaló szózatot intézni. ${ }^{202}$ A meglátás jó. Ez az ésszerütlenség csakis úgy számolható fel, ha azt feltételezzük, hogy az ének implicit célja egy szerelmi ígéret kicsikarása lehetett.

\section{Összefoglalás}

A Semmi állat nincsen... kezdetű vers nemigen feszegeti a 17. századi magyar szerelmi líra konvencióinak keretét. Invenciója keresetlen, diszpozíciója letisztult, elokúciós eszközei áttetszőek. Alkalmi voltát az átvételek reflektálatlansága jelzi: bár több alakzata felismerhetően más szerzők műveiből (jelesül Balassi Azmely keresztyén hü... ill. Rimay Örülhetne szivem... kezdetü énekéből) kölcsönzött, az elődszövegekhez való viszonyában aemulatív szándék nem mutatható ki. Szintén a konvencionáltságnak tudható be a hiperbolikus eszközök gyakori, ugyanakkor visszafogott érvényű kialakítása. Metaforikája a gyüjtemény azonos funkciójú verseihez hasonlóan - a trubadúr- ill. a petrarkista költészet közkeletü toposzain alapszik, ámde azok ideológiai felfogását kevéssé tükrözi, lévén az udvarias tropikán keresztül épp azt fejti ki: a viszonzáson múlik, hogy a továbbiakban miféle versekkel szolgál hölgyének.

\footnotetext{
${ }^{202}$ NAGY, i. m., 18.
} 


\section{Egy szép rózsaszálat küldtem ajándékon...}

$\mathrm{Az}$ ének izorímes, felező tizenkettesekben íródott. ${ }^{203}$ Három strófából áll, s ezzel a füzet legrövidebb költeményei közé tartozik. A verscsoport első ajándék-, azon belül is: virágkísérő verse, galantériáját ennek megfelelően nem is elsősorban a lovagi terminológia elkölcsönzésével, hanem a virágszimbolika által igyekszik kialakítani. Ilyenformán a levélvers egy speciális típusaként lehetne vele számolni. A gyüjtemény darabjainak általános jellemzője, hogy erősen s gyakran iskolásan közhelyesek, és csak kevés konkrétumot tartalmaznak, ezáltal igen széles körben válhatnak alkalmazhatóvá - s ez a tárgyalt énekre is vonatkozik. Kérdéses ugyanakkor, hogy képezhette-e valaha is udvarló szándékú misszilis tartalmát.

A versikéröl Eckhardt Sándor Balassi Most adá virágom nékem bokrétáját... kezdősorú költeménye örvén tesz említést: úgy véli, hogy az „ajándékvirágcsokrot magyarázó ének” ennek mintájára készülhetett. ${ }^{204}$ Kétségkívül igaz, hogy a virágküldés mint kulcsmotívum a füzet anyagának keletkezését megelőzően e körben egyedül ebben a versben maradt fenn, ugyanakkor e két szöveg számos további meghatározó mozzanatában olyannyira különbözik egymástól, hogy közöttük a direkt imitáció ténye bár feltehető, de nem tünik valószínűnek. ${ }^{205} \mathrm{~A}$ kérdést ezért (hogy a Balassi-életmühöz is láthatóan sok szállal kötődő versanyag pontosan miféle előzményekre tekinthet vissza) csak részben tartom megválaszoltnak. Eckhardt idézett megfigyelését ugyanakkor elfogadom kiindulópontnak, s az alábbiakban főleg e két alkotás eltéréseit katalogizálom.

Balassi versének alapötletére egyfajta distinctio telepszik rá: a régi magyar költői nyelv általános gyakorlatának megfelelően virágnak titulált kedves szimbolikus aktussal, egy csokor átnyújtásával fejezi ki a beszélőhöz való jóakaratát, mely gesztust az 1986-os KőszeghySzabó-féle Balassi-kiadás vonatkozó jegyzete úgy magyaráz, hogy annak értelmében „,az udvarlás elérte a legfóbb célját. „206

\footnotetext{
${ }^{203}$ Kritikai kiadása: RMKT XVII/12, 49. sz.

${ }^{204}$ Vö. BÖM, 174. A vers kritikai kiadása: Uo, 14. sz.

205 A szokás általánosan elterjedt voltáról ld.: KÖSZEGHY Péter, Balassi Bálint (1554-1594), Pozsony, Kalligram, 2009 (Magyarok Emlékezete), 100-101.

${ }^{206}$ Gyarmati BALASSI Bálint Énekei, kiad. Köszeghy Péter, SzABÓ Géza, Bp., Szépirodalmi, 1986, 277. A későbbi összkiadásban a jegyzetíró a korábbi álláspontot meghaladva már így vélekszik a kérdésről: „, $A$ bokrétaadás, a virág-kézbevétel nem feltétlenül metaforikusan értendö, nem feltétlenül azt jelenti, hogy az
} 
1. Most adá virágom nékem bokrétáját,

Magához hasonló szerelmes virágát,

Kiben violáját kötötte rózsáját:

Úgy tetszik, hogy értem ebböl ö akaratját.

A szexuál-metaforika vitán felül bármilyen virágmotívumban kimutatható. Csakhogy az ének következő strófája már a bokréta összetevőinek egyezményes jelentését részletezi (evidentia), mellyel elsősorban a szerelmesek ügyének tisztességes (honestum) voltát igyekszik bizonyítani.

2. Viola szép szine mutatja hüségét,

Rózsa piros volta hozzám nagy szerelmét,

Fejér rózsa penig mondja tiszta éltét;

Nézsze, mint mutatja bölcs és eszes elméjét!

A causa viszont csak akkor lehet erkölcsileg kifogástalan, ha az abban érintett személyeket egyaránt becsületesség jellemzi. A szándéknak megfelelően azonban mindez már a genus demonstrativum keretein átívelve, a tanácsadó beszédnem illokúciós eszközeivel fejeződik ki: a virág adása nem csupán ígéret, de kérés is egyben.

3. De látom, hogy ezzel nemcsak azt jelenti, Hanem viszont hogy én is oly légyek, kéri, Hü, tiszta, szerelmes légyen szivem, inti, Azminthogy ömagát is mondja hozzám lenni.

A gondolatmenet ilyetén alakulása azt a retorika mủvészetén kívül eső (inartificialis) konstrukciót látszik előkészíteni, mely végső soron a mü thesisének bizonyul, jelesül egy esküt. A negyedik versszakban a beszélő az udvariasság e szublimált jelrendszerében jártas hölgyéhez fordul, és hasonló regiszterben, lovagias fordulatokban bővelkedve fogad neki örök hüséget.

4. Azért e bokrétát, én édes szerelmem,

Megszolgálom s egészségedért viselem,

Mit parancsolsz véle nékem, igy jól értem,

Higgyed, tehelyetted nem kell senki más nékem!

Az eskü azután további argumentatív toposzokkal bővül. Balassi másutt is épít fel tropikát úgy, hogy az ahhoz kapcsolódó comparatio során sort kerít a betű szerinti és az átvitt értelem közti hasonlóságok mellett a különbségeket kifejtésére is. A már idézett Ötvenhetedik c. versében (Én édes szerelmem...) pl. arra a megállapításra jut, hogy noha a nőknek és a 
sólymoknak az idomíthatóság általában közös tulajdonsága, ő mégis hiába próbálja kezére hívni a versben sólyomként ábrázolt kedvesét. ${ }^{207}$ Ehelyütt az ötödik strófában ugyanez a metódus ismerhető föl:

5. De te ne kövessed ez bokréta dolgát, Ki noha most ily szép, de estve elhervad, Virágja mind elhull, csak a töve marad, Légy állandó hozzám végig, mint én tehozzád.

Erre a kitételre ehelyütt azért lehet szükség, mert lévén a vágott virágnál jobban a mulandóságot kevés ajándék reprezentálja, a bokrétaadás motívumából sehogy másként nem, csak az antithesis segítségével lehet eljutni a maradandóság (a szerelemre vonatkoztatva tehát a hűség ill. állhatatosság) kívánalmáig - e müveletről pedig alighanem a kölcsönösség ígérete hivatott elterelni a figyelmet.

Az utolsó sor ráadásul egy, az életműben szintén visszatérő, az ügyet a törvényszékiség (iudiciale) irányába elmozdító okfejtéshez vezet: ahogy a Hetvenharmadik c. versben (De mit gyötresz...), úgy itt is nagy hangsúlyt kap, hogy mindenféle esküszegés - így a szerelmi fogadalom be nem tartása is - egyenesen Isten ellen való vétek, s ezért sohasem marad büntetés nélkül. Mintha legalábbis fennállna annak lehetősége, hogy a csokrát nyújtó lányka még sincs mindenestül tisztában azzal, mire szerződött éppen.

6. Gondolj miközöttünk való kötelezést, Ne szerezzen senki miközöttünk eszvészt, Mert bánja az Isten fogadás szegését, Bünteti, héában aki vészi szent nevét.

Az éneket nem mellékesen kolofón zárja.

7. Ezerötszáz és hetvennyolc esztendöben,

Egy szerelmes helyen hogy volnék rejtökben, Az adá virágát akkor én kezemben,

Kit Istentül kérek gyakran könyörgésemben

A költő házasságáig szerzett költemények (vagyis az első harminchárom darab) közül csak egy: az Anna nevére szerzett Huszonhetedik (Az én szerelmesem...) tünteti fel záró strófájában a keletkezés évét - szintén 1578-at. E dátumból, ill. az idézett vers cikluson belül elfoglalt pozíciójából kiindulva a régebbi kutatók az abban invokált kegyest hol Krusith Ilona, hol Losonczy Anna személyével azonosították, ám a Balassi-filológia jelenlegi álláspontja szerint

\footnotetext{
${ }^{207}$ Vö. BÖM, 65. sz., 6. vsz. Ld. még a Ne gondold, szerelmem ... c. részfejezet tárgyalásában.
} 
nincsenek perdöntő érvek a címzett kilétének megállapítására ${ }^{208}$ - annyit azonban a szöveg legalábbis állít magáról, hogy valakinek és valamikor készült.

Az ismeretlen szerző tárgyalt éneke terjedelmében mindösszesen kevesebb, mint a felét teszi ki a fenti Balassi-münek. Ennek egyik oka, hogy sokkal lényegre törőbb annál: a rábeszélésen kívül más beszédnembe tartozó bővítményeket nem tartalmaz. Diszpozícióját tekintve jól szerkesztett egységet képez. Az első strófa az egyik legegyszerübb alaphelyzetet tükrözi: a beszélő férfi (a fikció keretein belül mindenesetre) egy szál rózsával ajándékozza meg kedvesét, s a továbbiakban ennek s kettejük ügyének hasonlóságait fejtegeti.

1. Egy szép rózsaszálat küldtem ajándékon,

Vedd tölem, szerelmem, el te azt oly okon,

Hogy szivünk nyugodjék köztünk egy szándékon,

Mint ez nött, nyillt, nyugodt szép harmatos bokron.

A füzet versanyagáról írott tanulmányában Bóta a vers több alakzatára is kitér, mint a Rimayt idéző virtuozitás iskolapéldáira. A fenti strófa utolsó sorának alliteráló elemeit (,nőtt, nyilt, nyugodt”) példának okáért a költőre a korban szinte kizárólagosan jellemző igeneves jelzőhalmozásként értékeli, csakhogy a congeries ezen összecsengő tagjai - szemben a keresetlenebb „,szép” és „,harmatos” kifejezésekkel, melyek mondattanilag félreérthetetlenül minőségjelzői funkciót töltenek be - inkább látszanak halmozott állítmányoknak. ${ }^{209}$ Szófajukat tekintve eszerint tehát éppen nem befejezett igenevek volnának, hanem olyan múlt idejü igék, melyeknek effajta mellérendelését Bóta egyébiránt szintén „stílusdetermináló” erejünek véli. ${ }^{210}$ Ezek az érvek ugyan nem bizonyítják maradéktalanul Rimay szerzőségét, de legalábbis egyazon iskola irányába mutatnak.

Abban viszont a tárgyalt szöveg határozottan elkülönbözik a nevesítettek praxisától, hogy a szerzője nemigen ügyel a felemlegetett szerelmes szándék tisztességes voltának egyértelművé tételére - mert (ahogy azt a Huszonnegyedik c. énekben ábrázolt bokréta is mutatja) a piros rózsa önmagában csupán magát a szerelmet jelenti, de annak tiszta és hü voltát már nem. Rimay szerelmi költészetében a rózsa mint alakzat előfordul a genus honestum és a genus inhonestum erkölcsi kategóriájába tartozó esetekben egyaránt, de egyértelmüsítve, mikor melyik fajtának a manifesztuma éppen. A korábban (a Szerelemtül

\footnotetext{
${ }^{208}$ Elöbbit véleményt Waldapfel (vö. WALDAPFEL József, Balassi költeményeinek kronológiája, ItK, 1926, 204205.) utóbbit Eckhardt Sándor (vö. BÖM, 174.) képviseli. Eckhardt ugyanakkor megengedi, hogy a címzett egy, a fent nevezettekkel nem egyező személy legyen.

${ }^{209}$ BÓTA, i. m., 14.

${ }^{210}$ Uo.
} 
csak kár... kezdetű ének örvén ${ }^{211}$ ) már érintett Valjon $s$ de mi haszon... kezdetű ének részben Ovidius Ars amatoriájának argumentációját átemelve - pl. a kicsapongó életvitel ártalmatlansága mellett érvel. Ezt példázza a második szakaszában megjelenített, sokak örömére illatozó rózsa is (exemplum ex minore ad maius), noha ez a tétel az ovidiusi eredetiben nem található meg, alkalmazását ezért Rimay saját invenciójaként kell elkönyvelnünk.

2. Rózsa miért kedves?Mert illattal büves, szaggal sokakot táplál, Így az a jó kegyes, azkinek sok nemes iffjú legény udvart áll. Mit árt azok közül, ha ki melléje dül, neki kedvére szolgál?

Jankovits László korábban idézett tanulmányának egyik megállapítása, hogy a fent idézett ének párversével, a Venus, fajtalan hús... kezdetűvel együtt afféle retorikai gyakorlatot (declamatio) képez, melynek lényege szerint a szónoknak tudnia kell bármely thesis mellett és ellen is jól érvelni. A szabad szerelem propagálása Venus (Cytherea) szózataként ágyazódik az Ars amatoriába. Ezt az ethopoeia trópusára hagyatkozó megszólalásmódot Rimay nemcsak követi a maga változatában, de az önmegtartóztatást hirdető ellendarabban is alkalmazza, lévén annak beszélője is egy antik istennő, ezúttal (a Venus rafináltra szőtt biztatása ellenében az invectiva eszköztárával felvértezett ${ }^{212}$ ) Diana szószólójaként határozza meg magát.

1. Venus, fajtalan hús, csipkébül tekert gúzs, elméknek bojtorjánja, Szederj természetö, ragadó beszédö, bujaságnak oltványa,

Kis gyönyörüséggel, soknak nagy veszéllyel romlásának kormánya!

2. Ki hihet te szódnak, ha nincs semmi jódnak állandó öröksége? Minden, ki követett, tüled nyavalyát vett, romlott is békesége, Senkit sem szerettél, azkinek nem lettél végre is ellensége!

3. Hadd, ne csald azokot, azkik ö magokot zászlód alá nem adták, Tiszta szép életben, mint rózsát szép kertben élteket be is zárták, Sereged tábora vivő sok gonoszra ösvényit nem is járták.

Ezek szerint Venus szerelme mégsem hasonlít a nemes rózsához, éppen ellenkezőleg: olyan, mint a vadon termett csipke, a bojtorján, vagy a szeder; márpedig a jó szerelem bokra csakis azoktól elzártan fejlődhet ki. Szintén Jankovits László megfigyelése, hogy a fenti sorok egyes fordulatai mintha egyenesen Venus betegségére, vagyis a szifiliszre utalnának. ${ }^{213}$ A tárgyalt vers következő szakaszának tropikája szintén a test ilyetén romlását látszik ábrázolni.

\footnotetext{
${ }^{211}$ Ld. a vonatkozó részfejezetet.

${ }^{212}$ Vö. JANKOVITS, Rimay és a civakodó istenasszonyok, 204-205.

${ }^{213}$ Uo., 210
} 
2. Mi szerelmünknek is vastagodjék ága,

Újuljon közöttünk naponkint virága,

Személyünknek köztünk kedves legyen szaga,

Rá soha ne hulljon semmi gonosz ragya.

Jól kivehető, ahogyan a második strófa első felének metaforái az előző halmozott hasonlatait (nőtt, nyílt, nyugodt) jelenítik meg igen érzékletes és áttetsző képekben. Csakhogy az udvarló hevület nem éri be a jó elérésének jellegzetes argumentumainak felmutatásával; a szerelmes egyszerre a rossz elkerülését is kívánja. Mivel azonban a szövegben a női test azután nyíltan ábrázolódik, az erre alkalmazott (immáron okságon alapuló) képiség nem valami általános balszerencsének, hanem kifejezetten a nemi úton terjedő betegségeknek meglehetősen naturalisztikus allegóriájaként lesz olvasható. ${ }^{214}$ Az efféle kerteletlen szabadosság viszont nemcsak Rimay hiteles verseinek világától idegen, de abban a Nagyciklus első harminchárom éneke sem szolgálhat mintául: ilyen per definitonem latrikánus metaforikát tisztességes hölggyel szemben nem lehet megengedni. ${ }^{215}$

Sajnálatos, hogy éppen e zavarba ejtő második versszakhoz nincsen apropója Bótának hozzászólni. ${ }^{216}$ A melléknévi igenévragozás okán felemlegetett első strófa után a harmadik is csak egy tollhiba miatt kerül a látóterébe, ami értelemszerüen kapóra jön feltevése alátámasztásához, miszerint Madách Gáspár csak ügyefogyott másolója volt a füzet anyagának. Az ugyanis eredetileg így áll a kolligátumban:

3. Ez küldtem rózsáért nem kivánok nagyot, Csak hogy hajts én hozzám szerelmes orcádot, Kire ragasztottad szép piros rózsádat, Hogy onnat szivinassa illetö szagodot.

Bóta úgy találja, hogy „az utolsó sor értelmetlensége teljesen megzavarja a különben költöileg igen szép gondolatot,” s ezért aztán a következő javítást eszközli rajta:

\footnotetext{
${ }^{214}$ A Balassi szerelmi költészetében megjelenő szerencse-felfogás értelmezését ld.: SzILASI, A sas és az apró madarak, 226-235.

${ }^{215}$ A Balassi-filológiában Varjas Béla nyomán nevezik a Balassa-kódex első 66 versét Nagyciklusnak, vö. VARJAS Béla, Balassi Nagyciklusa, ItK, 1976, 585-612. Varjas elképzelése szerint Balassi Bálint autográf versgyüjteménye, az ún. maga kezével írott könyv azonos lehetett ezzel a nagyobb szerkezeti egységgel, melyet a költő még Lengyelországba való kibujdosása (1589 nyara) elött állított volna össze. Noha Varjas többször hangsúlyozza, hogy a vercsoport mint , lirrai regény" v. ,fiktiv életrajz” értékelendő, a fentiek alapján bizonyos valóságreferencia ill. kronológiai vonatkozások mégicsak tulajdoníthatók annak.

${ }^{216} \mathrm{Az}$ ezzel kapcsolatos megfigyelései kizárólag a szag szó előfordulásainak kimutatására korlátozódnak; ti. hogy az megjelenik Rimay Kérdhetd ez koporsót...(RÖM, 1/VI. sz., 23. sor), Valjon s de mi haszon ... (RÖM, 17. sz., 4. sor), Itt egy asztalt látunk... (RÖM, 64. sz., 7. sor) kezdetü verseiben is.
} 
Hogy onnat szívhassam illető szagodot. ${ }^{217}$

Ez a hipotetikus változat ráadásul nemcsak a harmadik strófát, de a versike egészét tekintve is kézenfekvőbbnek tünik. Az utolsó versszakban ugyanis az okozatiság alakzatait felváltják a részesedéséi: a rózsa nem csupán hasonlít az invokáltra tulajdonságaiban, hanem el is látja azokkal. Az ajándékozás aktusa tehát attól válik kölcsönössé, hogy a kedves a beszélőhöz hajol a rózsától (vagyis a félreérthetetlen gesztus keltette felindulástól) kipirult arcával, hogy az magába szívhassa szerelmese rózsától kapott illatát. Ugyanakkor bár a gondolat költőileg szép, csakhogy azon túl fölöttébb udvariatlan is. Merthogy a fentiek implicit módon azt is jelentik egyben, hogy az illető hölgy az ajándékozás előtt minden bizonnyal sápatag volt és a legjobb esetben is szag nélküli.

\section{Összegzés}

Egy, a tárgyról írott korábbi dolgozatomban az Egy szál rózsaszálat küldtem ajándékon... kezdetű verset úgy értékeltem, mint a retorikai gépezet elszabadult müködésének eklatáns példáját, aminek diszfunkcionális jellege mintha abból következne, hogy a névtelen szerző nem uralja teljesen az elocutio - a nevesített mesterek által amúgy nagyrészt biztonsággal kezelt - eszközkészletét. ${ }^{218}$ Ámde mivel az ének máskülönben jól van megírva, meg kellett engednem azt az eshetőséget is, mely mindig ott kísért a mögöttes értelmükkel zavarba ejtő szövegek interpretációja fölött: eszerint azok esetlensége nemhogy nem szándékolatlan, de egyenesen reflektált lenne - az efféle művek idővel parttalanná váló diskurzusát a parodisztikusság hipotézise, úgy lehet, mindig képes mederbe terelni. ${ }^{219}$

Azonban a jelen kidolgozásban érvényesített további szempontok egy, az eddigiektől különböző javaslat irányába vezettek. Ha ugyanis figyelembe vesszük, hogy a magát levélként

\footnotetext{
217 „Hogy eredetileg ez a sor nem igy állt, azt bizonyitja, hogy a másoló elöször annath-ot irt, de mivel a következö szívhassa ige végéröl az $\mathrm{m}$ személyrag hiányzott, vagy azt nem tudta kivenni, áthúzta az annath-ot és annak-ra javította, amivel azután végképp elrontotta a sor értelmét, amely helyesen így lehetett az eredetiben: Hogy onnat szívhassam illetö szagodot." BÓTA, i. m., 7. Valójában azonban egyáltalán nem biztos, hogy Madách az onnath szót javította annak-ra és nem fordítva. Varga Imre a kritikai kiadás jegyzetei között valószínűnek nevezi a tollhiba tényét, ám mivel - meglátása szerint - a személycsere gyakori jelenség a kódexben, ezért úgy dönt, hogy a romlott sort a föszövegben javítatlanul közli. (Vö. RMKT XVII/12, 735.)

218 BALÁzs-HAJdU Péter, A romlás alakzatai: Adalékok Rimay János Tiszába esett könyvének tartalomjegyzékéhez $=$ Elözetes kérdések: Rohonyi Zoltán emlékkönyv, szerk. MILBACHER Róbert, Pécs, Kronosz, 2014, 25-32.

${ }^{219}$ Ld. pl. SZILASI László, A nyúl és a sólyom. Trópusok és funkcióik: Madách Gáspár Balassa János éneke sólymocskájárul címü versének példája, Literatura, 2000/3, 258-269.; BALÁZs-HAJDU Péter, Panna bendője: Egy 17. századi kurvacsúfoló retorikai olvasata, Acta Historiae Litterarum Hungaricarum Tomus XXIX, 2006, $25-32$.
} 
tételező énekben semmi nem utal arra, hogy címzettje úrihölgy volna (hovatovább abból a szerelmi szolgálatnak a mégoly klisészerü fordulatai is teljességgel hiányoznak), érdemesnek tünik megfontolni azt a lehetőséget, hogy esetleg nem is olyasfélének szánták. Ebben az esetben ugyanis kaphatunk valami képet arról, miként udvarol korának tanult poétája akkor, ha egyszerüen kalandot keres.

A 17. század szerelmi lírájának az az indoctus típusa, amely nem tud a cortezia intézményéről, bőségesen adatolható, viszont alig van emléke annak az irodalomnak, amely a lovagi költészet udvarias, de kevéssé illedelmes válfajaiból származó hagyományával is számot vetne. ${ }^{220}$ Márpedig az imént tárgyalt ének kétség kívül ebbe a szűk részhalmazba illeszkedik bele.

${ }^{220}$ Vö. SzIGETi Csaba, Közelitési kísérlet az obszcén antológiához, Prae, 2005/4, 24. sz., 53. 


\section{Látod ez gyöngyszemet...}

Az ének négy darab négysarkú, bokorrímelésü, felező tizenkettesekben írott strófát számlál, ezek közül az első mindegyik sorában csonkult. ${ }^{221}$ Ennek oka, hogy a verset őrző füzetlap (mely a harmadik levél rektója) felső részén a használat során szamárfül keletkezett, s az arra eső beírások jószerével olvashatatlanná váltak. E veszteségnek bizonyosan még az iratok felfedezése előtt kellett történnie, máskülönben a hiányzó tartalmat Radvánszky Béla - a köttetés alkalmával esett malör korrekciójához hasonlóan - közölte volna kiadásában. A szöveg teljességét az előző levél verzójának őrszava (Látod) tanúsítja. Felette a cím: Más.

A költemények sorában elfoglalt pozíciója ezúttal annyiból nem tünik teljességgel véletlenszerünek, hogy az előző, Egy szép rózsaszálat... kezdetü éneket követően ez a vizsgált anyag másik ajándékot kísérő verse. Mindamellett kirívó különbség a kettő között, hogy utóbbinak apropóját nem virág-, hanem ékszerküldés képezi. ${ }^{222}$ Amennyiben dolgozatom korábbi hipotéziseit (tehát ha egy korabeli lírai alkotásban a virágajándék leírását nem kíséri az alkalmiságon túlmutató amplificatio, akkor az óhatatlanul latrikánus jelleget fog ölteni) helytállónak tételezzük, ez megint a tizenöt ének képezte esetleges ciklus ellenében, és inkább a szimpla tematikusság mentén szerveződő katalógus mellett szól - mert igen valószínütlen, hogy a két vers egyazon beszélője történetesen ugyanazt a hölgyet szeretné előbb ideig-óráig, majd azután mégis inkább mindörökre megnyerni. ${ }^{223}$

Szilasi László Balassi költői nyelvének utóéletéről írott monográfiája arra a módszertani alapvetésre épül, mely szerint a 17. századi magyar költészet imitációs gyakorlata elsősorban szövegpárok vizsgálatán keresztül tapintható ki. ${ }^{224} \mathrm{Az}$ a tény, hogy a füzet tartalmának megalkotásával gyanúba fogott Rimay Jánosnak a tárgyul szolgáló énekhez hasonló ajándékkísérő költeménye nincsen, irreleváns - annál jelentőségteljesebb viszont,

\footnotetext{
${ }^{221}$ Kritikai kiadása: RMKT XVII/12, 50. sz.

${ }^{222}$ Bóta László e két altípus között nem lát olyan elementáris különbséget, amit a frazeológiai egyezések ne hidalhatnának át. Rimay szerzősége mellett ugyanis azt hozza fel érvként, hogy a tárgyalt ének 13. sora (,,Kövesd ez aranynak engedö lágy voltát”) feltűnően összecseng a Poema vigesimum quartum 17. sorával (,,De te ne kövessed ez bokréta dolgát"), s minthogy Balassinak Rimaynál hívebb követöje szerinte sem volt, a következö konklúzióra jut: „,Nem kétséges, hogy Balassi bokréta verse közvetlenül munkált közre a Rimay ének megszületésében." (BóTA, i. m., 15. Kiem. tőlem.) A magam részéröl már csak azért sem osztozhatom e határozottságban, mert a tanulmány szerzője sem képviseli következetesen ezt az attribúciós metodikát; pl. a Madách-Rimay-kódexekben fennmaradt $O$, csalárd világ... kezdetű énekét (RMKT XVII/12, 37. sz.) sem kísérli meg elperelni Madách Gáspártól Rimay javára, jóllehet Balassi szinte ugyanezzel a félsorral nyitja Kilencedik c. versét (Ó, te csalárd világ....).

${ }^{223}$ Ld. az elözö részfejezetben.

${ }^{224}$ SZILASI, $A$ sas és az apró madarak, 13.
} 
hogy Rimay ennek éppen a fordítottját eszközli ki az életmüvében, amikor a szerelmes verseit szerkeszti ajándékká. ${ }^{225}$ Ugyanakkor Balassi ún. „házasságáig szerzett”226 énekei között három, a tárgyalt vershez hasonló ajándékkísérő tételt is lehet találni: a Harmadik c. (Eredj, édes gyürüm...), a Huszonkettödik c. (Íme, az pelikán...) és a Vigesimum sextum c. (Szentírás szerint is...). Ezek mindegyike a többihez mérten önálló retorikai koncepciót tükröz. Annak eldöntésére, hogy e három közül melyik mutatkozhat esetlegesen a tárgyalt ének (direkt v. indirekt) előzményeként, először ezek sajátosságait tekinteném át röviden.

A Nagyciklus e belső mikrokorpuszából leginkább a középső vers (Íme, az pelikán ... ${ }^{227}$ ) ugrik ki. Az ugyanis nem a kísért holmit, hanem az azon található emblémát, jelesül a fiókáit önvérével tápláló pelikánét írja le (1 vsz.), értelmezi (2. vsz.), s vonatkoztatja az adott szerelmi szituációra (ld. alább) - szemben a másik kettővel, melyek általában azt sorolják, hogy az ajándék egyes fizikai jellemzői miben hasonlatosak annak egyes komponenseihez. Ebből adódóan a küldött ingóság mibenléte az ének soraiból nem is olvasható ki, s a konkrét alkalomtól eltávolítva csakis paratextusán keresztül válik érthetővé, ezáltal típusának legkezdetlegesebb válfajába sorolható. ${ }^{228}$

Az ajándékkísérő vers domináns trópusa (ahogy azt a vizsgált alkotások is mutatják) mindig a similitudo. ${ }^{229}$ Balassi ehelyütt a költemény alapötletéül szolgáló pelikán-toposzt is egyenlőtlen (impar), a kisebbről a nagyobb irányába (ex minore ad maius) vezető példává alakítja, mégpedig a következőképpen:

3. Ez oktalan állat ha ezt cselekeszi,

Én hát szeretömért szánjak-é szenvedni,

Ki szerelmemet szerelmével fizeti?

4. Megvagyon jutalma én szolgálatomnak, Nem mint az pelikán szörnyü halálának, Ki életét kárban adja fiainak.

A fentiek betủ szerinti, ill. allegorikus értelme aligha szorul bővebb magyarázatra, csakhogy e részlet az órigenészi négyszeres írásértelmezés - a 16. század mérvadó retorikai stúdiumait

\footnotetext{
225 Vö. „Ajánlom ez könyvvel magam mindenemmel tökéletességedben, / Gyámolj jó kedveddel, éltess szerelmeddel, viselj fottig kedvedben, / Sok jód szaporodjék, búd halma omoljék, könny száradjon szemedben." RÖM, 16. sz. (Én édes Ilonám...), 7 vsz. Ezt a megközelítési lehetőséget elsőként szintén Bóta László engedi meg, vö. BÓTA, i. m., 10.

${ }^{226}$ Vagyis a kódex sorrendjében az első harminchárom ének. Vö. Balassa-kódex, 57.

${ }^{227}$ BÖM, 10. sz.

${ }^{228}$ „Huszonkettödik, kit egy násfa felett küldött volt szeretőjének, kire pelikán madár volt feljegyezve.” Uo.

${ }^{229}$ A domináns trópus fogalmához ld.: SZILASI, A sas és az apró madarak, 16.
} 
tekintve ${ }^{230}$ - a vers keletkezése idején elevennek mondható tanának további két fajtája: a sensus moralis és a sensus anagogicus tükrében egy további jelentésréteggel is bír. Köztudott, hogy a vérével fiókáit új életre keltő pelikán legendája a kezdetektől nemcsak az önfeláldozó szeretet, de végső soron Krisztus és az Eucharisztia történetét is magában hordozza. Ezért a beszélő azon állítása, hogy az ő szerelme a választott példánál azért különb, mert kölcsönös, csakis azon a - ha nem is feltétlenül az udvarló költészetben - gyakorta hangoztatott előfeltevésen alapulhat (mintegy enthümemikusan), miszerint a Megváltó emberi nem iránt érzett szeretete viszont gyakran egyirányú.

Noha a Szentírás szerint is... kezdetű ének is függőt; nevezetesen egy gyémántkeresztet kísér, s az mint szimbólum szintén elidegeníthetetlen a vallási értelemtől, ámde a Vigesimum sextum másként operál e jelentéstartománnyal, mint a Huszonkettődik. ${ }^{231}$ A szerelmi kapcsolat fenntartásában érdekelt beszélő Krisztus kálváriája és a szerelmesek ügyes-bajos dolgai közötti hasonlóságot elsősorban azok fájdalmas voltában látja meg, ám ennek örvén (ugyancsak enthümemikusan) azt is bizonyítani igyekszik, hogy mindkettő elviselése Istentől rendeltetett kötelesség.

1. Szentírás szerint is kereszt csak bút jegyez, Én kínaimat is jelenti bizony ez, Mert nékem oly nehez,

Hogy szerelmem néked sok bánatot szerez.

2. De ha így végezte Isten, el kell türnünk, Minden szükségünkben neki könyörögjünk, Mert nincs hová lennünk, Ha segitségével nem lészen mellettünk.

Szemben az előbb bemutatott ének figuratív technikájával, a rábeszélés sikerét ezúttal nem valamely exemplum aprólékos kifejtése szolgálja, hanem hasonlatok sorozata. A megverselt gyémántkereszten függő három gyöngyből a kisebb szélsők nemcsak azért idézik a szerelmeseket, mert kereszten függenek, de azért is, mert kollineárisan teszik ezt, ami az egyenlőség, s azon keresztül - az argumentáció szerint - a hüség kívánalmára figyelmeztet, valamint ahogyan e két gyöngy közrefogva tartja a harmadikat, úgy ők sem hagyhatják veszendőbe menni szerelmüket. (Vö. 3-8 vsz.)

Balassi müveinek Kőszeghy Péter és Szentmártoni Szabó Géza gondozásában megjelenő népszerü kiadásait nem érheti e költemény túlértékelésének vádja. Azok ugyanis

\footnotetext{
${ }^{230}$ Vö. MELANCHTHON, i. m., 65-66.

231 BÖM, 24. sz.
} 
annak latin nyelvü argumentumát (Magus docte quam amatorie, magisque musis quam veneri canitur) a jegyzetek közt ezzel kommentálják: „,valóban inkább okoskodó, magyarázó, mint ihletett, az emblémaköltészet alkotásaival tart rokonságot. "232 Az idézett éneket egyébként az is közelíti az emblémaköltészethez, hogy 11-12. soraiban önmagára mintegy aenigmaként reflektál:

Mondd nékem értelmét,

Ha eszedben vetted ennek megfejtését!

Ami viszont az ihletettséget illeti (már amennyiben azt egyáltalán retorikai fogalmak mentén leírható jelenségnek gondoljuk el), annak hiánya talán nem csupán a kevéssé adekvát allegorikus jelentés hozzárendelésében ragadható meg. A beszélő nehezen képviselhető ügyet tárgyal (valamivel előbb-utóbb fájdalmat fog okozni kedvesének, de nem szeretné, hogy az emiatt megváljon tőle), s ezért - alighanem megkérdőjelezhetőségét leplezendő - egy csonka szillogizmusból kikövetkeztetett nem művészi bizonyítékra hivatkozik: az Isten akaratát kinyilatkoztató Szentírásra. Ebből adódóan az argumentáció inkább tekinthető etikus, mintsem patetikus eredetűnek, másként mondva inkább hat tanultnak, mintsem szerelmesnek.

Az áttekintés végére hagyott Harmadik c. (Eredj, édes gyüröm... ${ }^{233}$ ) versében a fentiekhez hasonló, teoretikus értelmet konnotáló szövegelem nincsen. Ahogy az elsőként tárgyalt ének (Íme az pelikán...) kezdetlegessége okán tünik ki a három közül, úgy ez éppen ellenkezöleg: absztraháltsága miatt. A megszólított ugyanis maga az ajándék, s ebből kifolyólag az aposztrophé jelen ideje a küldés, nem pedig a kézhezvétel fázisára vonatkozik (1-2. vsz.). Ezáltal a megajándékozott sem hallgatja, hanem kihallgatja a beszélőt ${ }^{234}$ - vagyis pozícióját tekintve lényegében nem különbözik a többi olvasótól:

1. Eredj, édes gyüröm, majd jutsz asszonyodhoz,

Ki viszen tégedet csókolni szájához,

Ó, hogy nékem ahhoz

Nem szabad most mennem én vigasztalómhoz!

2. Mondd szolgálatomat önéki én szómmal,

Kérjed, emlékezzék valaha felölem,

Ne felejtsen éngem,

Lám, csak benne vagyon én gyönyörüségem!

\footnotetext{
${ }^{232}$ Gyarmati BALASsI Bálint énekei, 277; BALASSI Bálint Összes müvei, 442.

${ }^{233}$ BÖM, 11. sz.

${ }^{234}$ Northrop FrYe, A kritika anatómiája, ford. SZILI József, Bp., Helikon, 1998, 210-211. Idézi: Jonathan CULLER, Aposztrophé, ford. SzÉLES Csongor, Helikon, 2000, 372.
} 
A vizsgált költemények közül a Harmadik feltünően sok világszerü megközelítést inspirált. Mivel a kódexben előtte álló Második c. énekben (Cupido szívemben... ${ }^{235}$ ) a beszélő történetesen arról számol be, hogy gyürüt kapott kedvesétől, ezért az a feltételezés, hogy e két vers (alkalmasint tehát a gyürüváltás ürügyén) szorosan összetartozik, szinte a kezdetektől része a Balassi irodalmi munkásságáról folyó diszkurzusnak. A Második köztudottan egy bizonyos Krisztina nevére íródott. A címzettet elsőként Széchy Károly azonosítja Dobó Krisztina (özv. Várday Mihályné) személyével. ${ }^{236} \mathrm{E}$ megállapítása a mai napig érvényben van. Ugyanakkor az az elképzelés, hogy - ezzel szoros összefüggésben - a Harmadik is Dobó Krisztinához szólna, hamar vitatottá válik; azt már Szilády Áron is Losonczy Annának ítélné - ahogy azt a Széchy álláspontját osztó Waldapfel József sommásan összegzi: , mint jóformán minden olyat, melynek versföiböl más nem tünik ki."237 Eckhardt Sándor szintén Ungnádné mellett hoz fel érveket, többek között azt, hogy a kitüntetett hölgynek az Eurialus és Lucretia hatását mutató jellemzése inkább illenék rá, mint (Dobó) Krisztinára. Végül aztán mégis egy titkos szerető mellett teszi le a voksát; valószínüleg azért, mert nem tud szabadulni a biográfiai adatok és a versszöveg között érzett ellentmondástól, miszerint a keletkezés feltételezett idején az elözvegyült Dobó Krisztina gyászéve nem járt le, Losonczy Anna pedig nem sokkal azelőtt vesztette el két gyermekét, a vers nőalakja viszont fehér ruhát visel. ${ }^{238}$

Ennek felidézésével mindösszesen csak arra szerettem volna felhívni a figyelmet, hogy e polémia kialakulása talán nem teljesen független attól, ahogyan Balassi egyedül ebben a versében veti össze az ajándék attribútumait a megajándékozott adottságaival, vagyis annak idealizált habitusa a vizsgált énekek közül csak a Harmadikban ábrázolódik. Teszi mindezt úgy, hogy a gyürü (alább részletezett) összetevőit ill. tulajdonságait demonstráló keretben a legértékesebb alkotórészt, vagyis az ékkövet részesíti kitüntetett figyelemben. A többi strófaszervező similitudo kivétel nélkül ahhoz méri a címzettet, ami az anyagi javak közt a legértékesebb: annak csak a gyémánthoz fogható ékessége a választékos beszéd és magatartás (4. vsz.); nívóját jelzi, hogy utánozzák, de el nem érhetik (5-6. vsz.); tisztasága az erkölcsös élet (7. vsz.); szilárdsága a megingathatatlan szerelmi hüség (8-9. vsz.).

A Balassi-nagyciklus ékszerkísérő énekeinek retorikai érdekü vizsgálatát követően végül rátérnék az ismeretlen szerzőjü, Látod ez gyöngyszemet... kezdetű vers tárgyalására.

\footnotetext{
235 BÖM 35. sz., 7. vsz: „Nemrégen gyüröt szerelmesem küldött, ki rubinttal mind rakva, / Egy szép drága gyémánt kellö középaránt vagyon közte foglalva, / Hozzám szerelemben tökéletes szíve is így vagyon kapcsolva." ${ }^{236}$ Vö. Balassa Bálint és Zrínyi Miklós, s. a. r. SzÉCHY Károly, Franklin, 1905 (Magyar Remekírók, 1), 17.

${ }^{237}$ WALDAPFEL, i. m., 207.

${ }^{238}$ Vö. BÖM, 169.
} 
Elörebocsátom: az a tény, hogy igazából erre eleddig senki nem tett kísérletet, alighanem az alkotás viszonylagos ötlettelenségének tudható be, ez pedig a következőkben ismerszik meg.

A füzet másik, hasonló típusú, az előző fejezet tárgyát képező verse (Egy szép rózsaszálat...) három strófájának ornátusát egyfajta szakaszos fejlődés jellemezte: az első versszakot uraló hasonlatokat a másodikban metaforák váltották föl, s azok szerepét végül - a vers második felétől - metonímiák vették át. ${ }^{239}$ Ehhez képest a Látod ez gyöngyszemet... kezdetű ének tropikája homogén, mert csakis hasonlatokban érdekelt. Az efféle szimplicitás ugyanakkor önmagában a virágküldő poéma dinamizmusánál nem feltétlenül gyöngébb stratégia - láttuk, a fent tárgyalt három Balassi-vers közül a Harmadik c. is eköré szerveződik. Anélkül, hogy e két, az ajándékkísérők egyazon altípusába sorolható szöveg (az Eredj, édes gyüröm... és a Látod ez gyöngyszemet... kezdetüek) között is közvetlen hatást feltételeznénk, érdemes tüzetesebben összevetni azokat. Egyként igaz rájuk a kifejezésbeli lehetőségek szűkössége: a similitudo hasonlított (valamilyen ékszer) és hasonló (a szerelem és/vagy a szerelmesek) tagja is többé-kevésbé determinált - ezért a nagyszámú motivikus egybeesésének sem indokolt túlzott jelentőséget tulajdonítani. Azzal együtt érdekes, hogy a Madách-Rimay-kódexek őrizte ének terjedelmében alig több Balassi nevezett költeményének egyharmadánál; a továbbiakban ezért azt vizsgálom, a Balassi-vers mely elemeit nélkülözi az ismeretlen szerző műve.

Az Eredj édes gyürőm... kezdetű ének bevezetéséül szolgáló alaphelyzetben, mint láttuk, a beszélő közvetetten intézi szavait kedveséhez, mintegy az aposztrophé által megfordított szituációval teremtve alkalmat a bemutatásra; ez a módszer teszi szükségessé az invokáció szerkezetileg elkülönülő kidolgozását (1-2 vsz.).

A tárgyalt vers személyhez szóló hangja ezt az eljárást nem igényli, ezért abban a transzgresszív exordium okkal lehet rövidre szabott:

1. Látod ez gyöngyszemet...

Fogyatkozásával szine wag...

Így vagyon én kezem te hozzád... ${ }^{240}$

És szerelmed miatt vagyon megherwa...

\footnotetext{
${ }^{239}$ Ld. ott.

${ }^{240}$ Megjegyezném, hogy a kéziratban a kezem szó hozam-ról lett átjavítva. (Vö. Madách-Rimay-kódexek, I, 35. Mindezt Varga Imre is megállapítja, vö. RMKT XVII/12, 75.) Ugyan az egymást követő szavak sorrendjének elvétése az egyik leggyakoribb másolási hiba, a vers egészének értelmét és a korábbi szövegközlésekben rögzített fenntartásokat tekintve mégsem vagyok teljesen meggyőzve arról, hogy Madách Gáspárnak végül a helyes változatot sikerült papírra vetnie.
} 
Azt, hogy a felütésből viszont egyáltalán nem vehető ki, pontosan miféle ékszert kísérnek e sorok, voltaképpen a töredékesség is okozhatja. (Erre egyébként az utolsó versszakból még kiolvasható lesz valami utalás.) Amennyiben mégis feltesszük, hogy a tárgyalt ének típusában megegyezik az írásbeliség legprimitívebb funkcióit reprezentáló, mert referálni csak az adott (valóságos) helyzetre képes Huszonkettődik c. verssel (Íme az pelikán...), észre kell vennünk, hogy attól eltérően ennek segédszövege (a cím, ti. Más) nem szolgál semmiféle kiegészítéssel - vagyis a füzet anyagának diszpozíciója újfent csak nem látszik motiváltnak egy átfogó poétikai szerveződés létrehozását illetően.

A kezdő strófa kulcsmotívuma (a gyöngyszem) fakó volta tehát a beszélő komorságát idézi. E képet az elküldött holmi zománcfénye ellenpontozza, ami a hölgy jókedvének fogalmi síkjával párosul:

2. Csak az te jó kedved ád néha szint néki, Mint ezt is az zománc szinével szépiti, És mikint az arany ezt ki nem ejtheti, Képedet szivem is úgy nem felejtheti.

A Harmadik c. versben ezzel szemben minden homlokegyenest ellenkezőleg van - és ez teszi, hogy az nagyságrendekkel elegánsabb. Ott ti. a hölgy tulajdonságait képviselő drágakővel szemben a zománc sötét fénye jelenti a beszélő gyászos kondícióját (vö. Eredj, édes gyüröm ..., 3. vsz.), és nem fordítva:

\footnotetext{
Mint te buritva vagy fekete zománcban, Így szivem is érte öltezett most gyászban, Búskodik magában.

Hogy nem részesülhet ö nyájasságában.
}

A hasonlítás során maga a foglalat is különböző intenciók mentén jelenítődik meg a két énekben: a Látod ez gyöngyszemet... kezdetüben mint egyszerü (neoplatonista eredetü) bókoló közhely gazdagítja az ornatust. ${ }^{241}$ Részben a következő versszak is ezt részletezi:

3. Forgása ez gyöngynek sem jegyez egyebet, Csak hogy elmém forgat szüntelen tégedet, Ne vond meg hát tülem te is kedvedet, Hadd foglaljam belém egészlen szerelmedet.

A Harmadik c. ének 11. versszakában ez már az óhajtott hüségnek lesz újabb metaforája:

Foglaljon engemet szinte úgy magához,

\footnotetext{
${ }^{241}$ Vö. ,,[A] szerelmes bevési szeretettje alakját a lelkébe, és így a szerelmes lelke egy tükör lesz, amelyben a szeretett képe ragyog...” Marsilio FICINO, Commentarium [I], ford. IMREGH Mónika, Pompeji, 1993/1-2, 243.
} 
Miképpen ez gyüröt foglalták gyémánthoz,

Ne hajoljon máshoz,

Légyen igaz hozzám, mint hív szolgájához!

Az ismeretlen szerző költeményében azonban a foglalat mintha összetartozna a belefoglalt kellék egy további tulajdonságával, amely szintén a beszélő speciális helyzetével állítható párhuzamba; jelesül elszakadni azt nem, csak forogni engedi, mint ahogyan a szerelmes gondolatok is csak egy tárgy körül járhatnak. Ez a képzet már a Bírja bár akárki... kezdetü énekben is alakot ölt, méghozzá a Bóta László gyanúját is felkeltő (mert a Célia-ciklus ötödik darabját idéző) malom-hasonlat alapjaként. ${ }^{242}$ Most Bóta csak annyit tart fontosnak megjegyezni, hogy a 11. sor eggyel kevesebb, a 12. pedig eggyel több szótagot tartalmaz a kelleténél. Emendálási javaslatait azonban Varga Imre még ahhoz is túlzottan önkényesnek találja, hogy egyáltalán ismertesse azokat a kritikai kiadás jegyzetapparátusban. ${ }^{243}$ Annotáció nélkül elfogadja viszont a 14. sor ritmusának helyreállítását: ${ }^{244}$

4. Kövesd ez aranynak engedö lágy voltát, Törés nélkül adja kezednek hajoltát, Életednek hozzám nyújts te is lágy foltát, Így enyhitsed bennem tüzemnek nagy voltát.

A befejezésből nyert, az ajándékra vonatkozó újabb adalékok alapján válik tehát világossá, hogy a Látod ez gyöngyszemet... kezdetü ének valamilyen karékszer, vagy talán szintén egy gyürű kíséretéhez íródott. ${ }^{245}$ Ezek közül a szerző e küldemény anyagából vesz példát az alakíthatóságra, míg (attól szintén eltérően) Balassi a maga esetében annak alakjából a végeérhetetlenségre (vö. Eredj, édes gyürőm..., 10. vsz.):

Ezt megmondván neki, utolszor kérd erre,

Hogy miként az gyüröt foglalták jól eszve,

Nincsen sohul vége,

Legyen igy vég nélkül énhozzám szerelme.

\footnotetext{
${ }^{242}$ BÓTA, i. m., 15.

${ }^{243}$ Bóta László az előbbi szótaghiányát (a Ne gondold, szerelmem... utolsó előtti sorának analógiájára) a víg jelző betoldásával, az utóbbi szótagtöbbletét a szerelmedet rímfelelő lecserélésével (a petrarkisták által kiérlelt lélek- ill. szívcsere toposznak megfelelően inkább *lelkedet v. *szivedet szóra) érzi kiigazíthatónak. Vö. ВóTA, $i$. m. 8 .

${ }^{244}$ Az utolsó strófa második sora ti. a kódexben így olvasható: „Törés nélkül adja kezeidnek hajoltát.” Emellett Bóta hibásnak találja az adja szót is; meglátása szerint az eredetileg *adjad alakban állhatott. Ez az olvasat azonban értelmileg nehezen igazolható. Vö. Uo. Varga erre vonatkozó jegyzeteit 1. RMKT XVII/12. 76, 735. Érdemi támpontot tehát, mely a vers történeti megítélését segítené, e kizárólag a szerzői szándék rekonstrukcióját célzó filológiai megfontolások láthatóan nem adnak.

${ }^{245}$ A kéz szindekdochikusan jelenthet ujjat is. Vö.: „,Nem esik le a gyürü a kezéröl.” O. NAGY Gábor, Magyar szólások és közmondások, Bp., Gondolat, 1976, 212. sz., 255.
} 
A végére érve tehát mindkét vers beszélője - mint ahogy arról már többször esett szó: a verstípus rendeltetésének ill. konvencióinak megfelelően - szerelme engedékeny avagy örökké tartó viszonzására igyekszik rábeszélni választottját; ahogy a szerelmi líráról egyébként is általánosan elmondható, hogy abban a bemutató beszédnem (demonstrativum) a tanácsadóval (deliberativum) keveredik.

Szembeötlő, hogy a tárgyalt vers minden szakaszához hozzá lehetett rendelni a Balassi-vers egy-egy (hasonlósága ill. különbözősége okán) parallel verszakát - ami nyilvánvalóan abból a már korábban említett tényből adódik, hogy az ajándékküldő versek eszközeinek játéktere erősen korlátozott, szerzőik tkp. csak az egyes klisék v. közhelyek közül válogathatnak, ezért e jelenségből továbbra sem kell feltétlenül e két szöveg direkt imitációs kapcsolatára következtetnünk - vagyis úgy tünik, négy strófányi terjedelem vígan elegendő egy efféle poéma megformálásához. Az a Balassi vers nagyobb kitevőjét képező többlet, a tulajdonképpeni propositio (4-9. vsz.) ugyanakkor, mellyel a Látod ez gyöngyszemet... kezdetű ének nem rendelkezik, nem egyszerüen hasonlatokon át létrehozott, elhúzódó leírás, hanem személyi érvekkel (argumenta a persona) kifejezett permanesns méltatás, magyarán a bókok sora.

A Harmadik c. költemény példája szerint tehát nem szükségszerü, hogy (mint e verstípus oly gyakran) a szerelmes rábeszélés a beszélő iránti szánakozás felkeltésére (conquestio) törekedjen, ha a mondanivaló zömét a szakadatlan laudáció adja - nos, ismerte vagy sem a füzet e versének szerzője Balassi Bálint Eredj, édes gyürőm... kezdetű énekét, e vívmánytól legalábbis érintetlen marad.

\section{Összegzés}

A fenti elemzéseken keresztül olybá tünik, hogy Balassi az ajándékküldő versek hagyományos sémáit kétféle módon dolgozta ki. A rábeszélő szándék az egyikben (Íme az pelikán...; Szentírás szerint is...) a képes magyarázat a szerelem Istennek tetsző mivoltára szorítkozik (s így a törvényszéki beszédnemmel látszik elegyedni), míg a másikban (Eredj, édes gyürőm...) a legnagyobb hangsúlyt a hölgyének külső és belső kvalitásait magasztaló deskripcióra fekteti. Utóbbi esetében megint az aposztrophikus fordulatban rejlő lehetőségeket munkálja ki: ezúttal is a harmadik személyü hölgyszereplő komparatív szemléltetése eredményezi alakjának többirányú (plasztikus) ábrázolását. 
A Madách-Rimay-kódexek tárgyalt éneke ezek közül jobbára a Harmadik c. verssel rokonítható, lévén nemigen tartalmaz olyan elemet vagy eszközt, amit abból ne lehetne kimutatni. (Ami egyaránt lehet tehát konvenció vagy közvetlen mintakövetés eredménye.) Ám azzal, hogy az ismeretlen szerző - talán a brevitas kötelmét túlhajszolva, vagy takarékosságból - beéri a verskészítés legalapvetőbb paneljeivel, le kell mondania a suasio olyan, a szánakozáskeltésnél jóval tetszetősebb eszközeiről is, mint pl. a gáláns bókolás.

Olyasfajta ajándékkísérő versike, melynek legkirívóbb alkotástechnikai eszménye a tömörítés, a valamivel később (a század derekán) írott verses önéletrajzi drámájában magát Balassi szukcesszoraként identifikáló gróf Balassa Bálint tollából is maradt fönn $-{ }^{246}$ mindenesetre erre vall, hogy hátrahagyott irataiban egyazon költeménynek egy hat-, majd egy ötsoros változatát is lejegyezte: ${ }^{247}$

\author{
Parancsolatodra küldöm hat kövemet, \\ De ne véljed azért lenni köszivemet, \\ Lágy hozzád, s általok értsed hívségemet, \\ Úgymint zöld jel által jó reménységemet, \\ Azmint én jelentem hiv szeretetemet, \\ Te is szeress, hogyha várod életemet.
}

\author{
Most elöljáróul küldöm három pár kövemet \\ Küldém, de ne véljed azzal kőszívemet, \\ Lágy hozzád, ösmerjed inkább hívsigemet, \\ Szeress, ha kívánod hosszabb életemet, \\ Zöld kövel jelentem jó reménségemet.
}

Végezetül csupán e variánsok két jellemzőjét szeretném röviden kiemelni. Az egyik, hogy mindkettő üdítően mentes a szerző kvázi védjegyeként ismert önsajnálatától. A másik, hogy az udvarolt hölgy milyensége viszont egyáltalán nem jelenítődik meg azokban. Már csak ezért is érdemelne további vizsgálatokat, pontosan miben is látta gróf Balassa örökségének lényegét. $^{248}$

\footnotetext{
${ }^{246}$ VARGA, Gróf Balassa Bálint..., 446.

${ }^{247}$ RMKT XVII/12, 107-108. sz.

${ }^{248}$ A kérdésröl 1. még: SzILASI, A sas és az apró madarak, 55-58. ill. Kocsis Viktória, Honnan gyüjtögetnek a méhek? Adalékok a hagyomány felderitésére gróf Balassa Bálintnál = Mikro \& Makro: Fiatal kutatók konferenciája, szerk. LOVAS Borbála, NÁDOR Zsófia, SZATMÁRI Áron, SzILÁGYI Emőke Rita, Bp., 2013. (Arianna, 6), 165-169.
} 


\section{Oly nehéz nem látnom elöttem járnia...}

Az ének címe: Más. ${ }^{249}$ Négy strófából áll, formája izorímes, de (a füzet rendjében elsőként) heterometrikus; képlete: a12, a12, a6, a12 - vagyis ún. Palkó-vers. ${ }^{250}$ Megjegyzem, a gyüjtemény leggyakoribb idoma, a felező 12-es e váltást követően (egyetlen kivételtől eltekintve $)^{251}$ többet nem jelentkezik. A Palkó nótájára viszont szintén íródik egy további: a Beborult, fölhözött... kezdetü tétel. ${ }^{252}$

Azt az evidenciát, miszerint a Balassi-strófa (mely összességében a tizenöt ének második leggyakoribb strófaformája) inkább megkívánja a virtuóz rímelést, mint az említett formák, Bóta azon akkurátus megfigyelésével kiegészítve közli dolgozatában, hogy a kódex szerelmes verseiben az egyszótagos rímek mindig - szerinte: módszeresen - az utóbbiakat, és soha nem az előbbieket ékítik. ${ }^{253}$ Kiemeli továbbá a Balassa-kódex Rimay-anyagának Második c. (Ne csudáld szivemet...) énekét, mint visszafogott retorizáltsága okán az egyetlen üdítő kivételt, s azt írja, hogy annak tartalmi, hangulati és formai keresetlensége a 17. század eleji szerelmi költészet magyar nyelvű emlékei közül leginkább épp az itt tárgyalt korpusszal rokonítható. $^{254}$

Meglátásait Bóta természetesen az ismeretlen szerző és Rimay János azonossága mellett szóló közvetett érvként igyekszik kamatoztatni, hozzátéve, hogy említett művében „Rimay arról beszél, hogy távol vált kedvesétöl, akinél már szerelme jutalmát is érzi, és ez annál fájóbb számára. Ily távollétében csak azt kívánja, hogy kedveséröl jó hírt halljon és vele mielöbb vigadhasson. Végül Isten áldását kéri szerelmükre.” S megjegyzi, hogy e fordulatok nemcsak ebben az énekben, de a vizsgált kézirat két verses levelében is megjelennek. ${ }^{255}$

Valójában a füzet három szoros értelemben vett, tehát akár önálló küldeményként is funkcionáló levélverset tartalmaz: a tanulmány által hivatkozott Ércnél, kösziklánál... (53. sz.)

\footnotetext{
${ }^{249}$ Kritikai kiadása: RMKT XVII/12, 51. sz. A betűhív átiratot modernizáltam.

${ }^{250}$ Ennek a bizonyos Palkónak a kilétét illető fejtegetéseket ld.: BÖM, 169.

${ }^{251}$ Az Örülj immár, lelkem... kezdetü (RMKT XVII/12, 56. sz.).

${ }^{252}$ RMKT XVII/12, 57. sz.

253 „A M-R kódex néhány szerelmi éneke a példa rá, hogy ezen [értsd: a rímjátékon] kívül még mi minden stílusékitményt lehet belekölteni olyan egyszerü strófakeretbe is, mint pl. a Palkó-vers, vagy a négysoros 12-es. Ebböl a szempontból különösen figyelemre méltó a Radvánszkynál a 19. sz. "Oly nehéz nem látnom «és a 25. sz. »Beborult fölhözet« kezdetü énekek, melyek müvészi megformáltságukkal Rimay ismert szerelmes verseit is túlszárnyalják.” BÓTA, i. m., 23.

${ }^{254}$ Vö. BóTA, i. m., 11. A pontos idézetet ld. a Ne gondold, szerelmem... c. éneket tárgyaló részfejezet 87. lábjegyzetében.

${ }^{255}$ Uo.
} 
és Szerelmesitöl vált... (54. sz.) kezdősorú költemények mellett e típusba tartozik a Szerelmese jobb kezének írását köszönti (55. sz.) címü is. Ez utóbbit Bóta vélhetöleg azért nem említi, mert invenciójában kevéssé illeszkedik a fenti sémához. E három ugyanakkor más tekintetben mégis összetartozik (ahogy arról később, e versek részletes elemzése során bővebben esik majd szó): pl. tipográfiailag is. ${ }^{256}$

Az említett klisék (az elválás fájdalma, a távollét szomorúsága, a viszontlátás reménye) úgy lehet, alapvetően a verses levél típusát idéző elemek - ám nyilvánvalóan nem minden szöveg reflektál ebbéli minőségére. Ha emellett valóban figyelemmel vagyunk a Bóta által jelzett verstani ill. retorikai szimplicitásra is, épp ezáltal láthatjuk be, hogy Rimay Második c. alkotásához a tizenöt közül technikai értelemben sem más, mint az Oly nehéz nem látnom... kezdetű ének áll a legközelebb. ${ }^{257}$ Ezért a továbbiakban e kettő hasonlóságait és különbségeit tárgyalom.

Megoszlanak a vélemények arról, hogy a Ne csudáld szívemet... kezdetü ének tekinthető-e egyáltalában levélversnek. Ahogy azt Jankovits László egy, a költeményröl írott dolgozatában felidézi, értékelték azt már szerelmeslevélként és magánbeszédként is. ${ }^{258}$ A kommunikációs szituáció meghatározásának ilyetén nehézségei pedig alighanem a kapcsolatteremtő figurák körmönfont megmunkálásából fakadnak:

1. Ne csudáld szívemet, hogy illyen keserves, Szerelem tüzitül mert megsérölt sebes. Hogy attúl távol vált, azkihez köteles.

2. Hogy ne legyen penig az után nehezen, Kinél szerelminek jutalmát is érzem, Mert ö sem gyölöl, lám, mint eszemben veszem.

3. Titkos tekintete rám kedvvel mosolyog, Szeme szép világa rajtam gyakran forog, Ha nem láthat, mondják, hogy értem szomorog.

\footnotetext{
${ }^{256}$ Ld. az Ércnél, kösziklánál... kezdetủ énekről írott részfejezetben.

${ }^{257}$ Vö. BÓTA, i. m., 11. A kritikai kiadás jegyzeteinek tanúsága szerint Varga Imre e kérdésben Bóta nyomán azonban arra az álláspontra jut, hogy a Ne csudáld szivemet... és az Oly nehéz nem látnom... kezdetủ ének bár „, hasonló lírai alaphelyzetben fogant”, Rimay verséhez mégis közelebbi a füzet 12. tétele (Szerelmesitöl vált...). Vö. RMKT XVII/12, 735, 736.

${ }^{258}$ JaNKOVITS László, Vö. JANKOVITS László, Soliloquium és oratio Rimay egy versében (Ne csudáld szivemet...) = Stephanus Noster: Tanulmányok Bartók István 60. születésnapjára, szerk. JANKovics József, JANKOVITS László, SZILÁGYI Emőke Rita, ZÁsZKALICZKY Márton, Bp., reciti, 2015, 213. A szerző által idézett szempontok: H. HUBERT Gabriella, Radvánszky János kódexe (Stoll 127. sz.) = Ghesaurus: Tanulmányok Szentmártoni Szabó Géza hatvanadik születésnapjára, szerk. CsöRSz Rumen István, Bp., rec.iti, 2010, 405-407; ÁCs Pál, Rimay János korai versciklusai, ItK, 1989, 310.
} 
4. Ily távol létemben én mint kévánhassak?

Ha nem, hogy felöle minden jót hallhassak,

Véle rövid napon együtt végadhassak.

5. Te, kegyelmes Isten, mindkettünk szerelmét Neveljed, s tartsad meg testünk egészségét,

Foghassuk örömmel hamar egymás kezét.

6. Én édes Lydiám, vég légy, ne bánkódjál,

Hozzám szerelmedben mindvégig hiven állj,

Isten adjon jó éjt, csendessen aludjál.

Látjuk, az ének hat versszakából három tartalmaz megszólító formulát. A beszélő mégis csak a két utolsó strófát kitevő zárlat címzettjeit nevesíti, a felütésben megszólítottét nem. A különböző értelmezések ezért főként annak függvényében térnek el, kiben látja az olvasó az első versszakban invokált személyt. ${ }^{259}$

A Rimay-vers e szakaszának közhelyszerü szóképei (a szerelem tüze által megsebzett szív) a beszélö állapotát írják le, egyéb szemantikai eszköz - az állandósult metaforákat leszámítva - a költeményt nem ékesíti; tehát a pragmatikai alakzatok gyakori alkalmazása dúsítja a köznapi tropikát, s egyben választékos jelleget kölcsönöz az alkotásnak: a bevezetés attentív fordulata (,,Ne csudáld...”) arra utal, hogy az ügy - erkölcsi szempontból - igenis csodálatra méltó (genus admirabile), a megszólítás repetitív aktusa természetszerüleg a tanácsadó beszédnemhez (deliberativum) köti a vonatkozó részeket.

Ehhez képest a tárgyalt ének retorikai kidolgozása valóban egyszerünek tünik. Nyitó versszakát az előbbitől eltérően sem pragmatikai, sem szemantikai figurák nem díszítik: stílusékítmények ehelyütt mindössze egyes szavak ill. szintagmák alliteráló voltában és egy similitudo beiktatásában ragadhatók meg. ${ }^{260}$

1. Oly nehéz nem látnom elöttem járnia, Mintha elment volna tülem messze útra, Hagyott volna búra,

De viszont vigadok, ha magát mutatja.

Viszonyításképpen Bóta - a Madách-Rimay-kódexek szerelmes verseiben és a Balassi- ill. Rimay-életmüben egyaránt elöforduló frázisokat katalogizálva - többek között a Nagyciklus Második c. versének (Cupido szívemben ...) 4. strófáját találja említésre méltónak:

\footnotetext{
259 JANKOVITS, Soliloquium és oratio, 213-215.

${ }^{260}$ Az ének első sora a kéziratban eredetileg így található meg: „, Oly nehez nem latom elotem Jarnia. ” (MadáchRimay-kódexek, I, 35). A modernizálás során elfogadtam Bóta emendálási javaslatát, mely szerint „, $a$ látom ige helyett ragozott fönévi igeneves alakot követel a mondat értelme. ’BóTA, i. m., 8.
} 
4. Siralmas nagy bánat különben nem bánthat, csak mikor öt nem látom,

Szép kertek tömlecnek akkoron tetszenek, víg ének is siralom,

Viszont mikor látom, vagy szavát hallhatom, nincsen semmi bánatom.

Ám tekintve, hogy Bóta érdeklődése ezúttal is az egybeeső szóhasználatra irányul, megelégszik a két szakasz első és utolsó sorának idézésével; ezzel azonban rejtve marad egy további párhuzamosságuk, mégpedig hogy egy-egy hasonlatot fognak közre. Ezek felépítése viszont nem egyforma. Balassi antonimapárokból hoz létre rendre az oxymoron irányába tendáló figurákat, az ismeretlen szerző pedig a szolid túlzással operál. Érdemes megfigyelni, hogy ebben jelenik meg hasonló elemként a távollét képzete - vagyis az csupán a szöveg egy alakzatában vetödik fel, a lírai alaphelyzetnek amúgy nem része.

Ez azért is fontos, mert ez a feltétel (,,Mintha elment volna tülem messze útra”) a kortárs költészetben nembeli korlátokba látszik ütközni: csak a férfiszereplők számára megengedett. Hogy csupán az eddig említett verseket idézzük:

Illy távol létemben én mint kévánhassak?

(Ne csudáld szívemet...10. sor)

Adod is értenem, / Töled eljöttelem / Mint újult meg keserved

(Ércnél, kösziklánál..., 13-15. sor)

S noha eltávoztam, / De velem elhoztam / Szivemben zárt képedet

(Szerelmesitöl vált..., 5. sor)

Várjon víg örömmel,/Mert én is jó kedvvel / Megyek szép személyéhez

(Én édes jobb kezem..., 7. sor)

Úgy látszik tehát, hogy amíg a 17. századi mindennapok valóságában természetesen a hölgyek is útra kelhettek ilyen vagy olyan ügyekből kifolyólag, s ez nyilván eredményezhette egynémely szerelmi kapcsolat ideiglenes vagy végleges megszakadását, addig a lovagi-udvari hagyományokra építkező költészet toposzai rendületlenül őrizték azt az archaikus koncepciót, melynek értelmében ez a privilégium mindenekelőtt a férfiakat illeti.

Ebből adódóan pedig fontolóra kell venni azt az eshetőséget, hogy a tárgyalt alkotás beszélője egy/a nő. Ilyeténképpen (női dalként) az Oly nehéz nem látnom... kezdetű ének mint az idézett Rimay-verssel vetekedő certamen volna értelmezhető. 
A következő strófában a beszélő személyisége részekre tagolva (szinekdochikusan) ábrázolódik azt demonstrálva, hogy annak érzelmi és értelmi komponensein egyaránt elhatalmasodott a szerelmi vágy: ${ }^{261}$

2. Lenni nála nélkül szívem nem kívánja,

Nézni is reája két szemem nem unna,

Álomra nem hunna,

Ha hunnék is, elmém vele álmodozna.

Ezzel Bóta ismét több közismert szöveghelyet ítél parallelnek. Ilyenek pl. Rimay Én édes Ilonám... kezdetü énekének kezdősorai:

Én édes Ilonám, tizedik bölcs múzsám, kinek szavát nem unnám,

Te vagy negyed Charis, okosabb annál is, kit méltán kedvelt Páris...

A kettő esetében, látjuk, nemcsak az állítmány egyezik, de annak igemódja is. Szorosabb összefüggést nehéz lenne bizonyítani közöttük, mégis jól kivehető az eltérés: az ismeretlen szerző egyszerü toldalékrímes verselési technikája úgy kívánja, hogy a feltételes mód végigkísérje az egész strófát. Csakhogy ettől abban kitapintható lesz egy apró, alkalmasint szándéktalan, mindenesetre megmosolyogtató mozzanat. Ennek belátásához vegyünk egy másik citátumot, Balassi már érintett Mire most, barátom... kezdetü költeményének 27. versszakát: ${ }^{262}$

Fészket vert szivemben már az ö szerelme,

Elöttem szüntelen képe, jó termete,

Ha szinte aluszom is, álmodom véle,

Mert csak övé vagyok, senkié sem egyébé.

A Balassi-vers szerelmese tényként közli, hogy egy jelen nem lévő hölgy alakját látja nappal és éjjel. A vizsgált szöveg beszélöje ezzel szemben azt szeretné, hogy kedvese konkrétan a látóterében legyen; mint ígéri, ha mindig így volna, szemeit nem venné le róla és nem is csukná álomra - vagy ha ez mégsem kivitelezhető (hogy a revokált túlzást egy másik, legalább annyira triviális hiperbolával korrigálja), akkor is mindig vele álmodna.

\footnotetext{
${ }^{261}$ Az ének nyolcadik sora a kéziratban így olvasható: „Ha hunnekis, elmem vele (vigadozna) almodozna.” (Madách-Rimay-kódexek, I, 35). Bóta a kerek zárójelet javításként értelmezi, és a benne foglalt szót a továbbiakban elhagyja a közlésből (BÓTA, i. m., 8.), Varga Imre a Régi Magyar Költők Tárában mégis beemeli a föszövegbe, s ezt a következőképpen indokolja: „, Madách nem szánta ezt javitásnak; sohasem javított úgy, hogy a zárójelbe tett szó után irta volna a jobbik megoldást." (RMKT XVII/12, 76, 735.) Ez valóban így van: Madách Gáspár vagy akkurátusan kisatírozza, vagy fölülírja a rontott szövegrészt. Elképzelhető tehát, hogy ehelyütt vagy azt másolta, amit látott, vagy - miután sem ritmust, sem értelmet nem rontott vele - jelölte ugyan a maga variációját, de meg is hagyta azt. E két lehetőség egyként fakultatív rímet eredményez.

${ }^{262}$ Szintén az álmatlanság apropóján, ld. a Semmi állat nincsen ... kezdetủ énekröl írott részfejezetben.
} 
Az óhajtás mellett a fogadkozás is eltávolítja a szöveget a jelenre vonatkozó szemléltető beszédnemtől; a jövő idejü cselekvések ill. történések a genus deliberativum körébe tartoznak. Nincs ez másként a harmadik versszakban sem, de nem árt észrevenni: szemben a Rimaytól látott gyakorlattal, itt a burkolt kérések gondosan kerülik a felszólító mód alkalmazását.

3. Nem késem, meglátom, magam neki adom,

Ha Isten békével hordozza ez úton,

Bár víg szívvel járjon,

Reménlem, hogy hamar szép kezét foghatom.

Az első sort kitevő enumeratio utolsó tagja a mai olvasó nyelvérzéke szerint úgyszintén a beszélő hangjának feminin jellegét erősíti. Valójában azonban éppen ez a szófordulat kérdőjelezi meg a korábbi feltételezésünk érvényességét. Ennek értelmében ti. az alany egy kifejezetten lovagias tettet készül véghezvinni - kitünően bizonyítja ezt Balassi Szerelem s Julia... kezdetű versének címe (Negyvennyolcadik, hogy Júliának s nem az Szerelemnek adta meg magát) ill. ennek 7-8. sora:

Nem adom magamot néked, meghidd - mondok-, noha mindenekkel bírsz, De ím, ez kegyesnek holtig rabja lészek...

A valakinek magát adni fordulat tehát annyit tesz a korabeli nyelvhasználatban, mint megadni magát valakinek; vagy ahogy Balassi szinonim értelemben is megfogalmazza: rabjává lenni. Nem kizárt, hogy a tárgyalt vers esetében a lovagi terminológia mellőzése összefügg a tropológiai ékítettlenségével, mivelhogy az udvarias közhelyek hiánya és a puritán képiség egyként jellemző a szövegre.

Így nem kimondottan gáláns abban a kézfogás - a Ne csudáld szívemet... 5. strófáját idéző - motívuma sem, amit Bóta a kor verses leveleinek általános (topikus) rekvizitumának titulál; ${ }^{263}$ és amelynek gesztusát Jankovits a jegyváltás értelmében magyarázza. ${ }^{264}$ Méghozzá ebben a formában azért nem, mert ennek létrejöttét egyik szöveg sem kizárólag választottjától teszi függővé; ügyét mindkettő Isten kezében látja. A megszólító alakzatokkal operáló Rimayversben ez explicit könyörgésként artikulálódik. Ugyanitt ennek oka, a szerelem kölcsönös volta is része az argumentációnak: a beszélő joggal hiheti, hogy kedvese „,nem gyülöli” (2. vsz.), mert ennek számos jelét (signum) tudja felsorolni (3. vsz.). Az ismeretlen szerző versében ez a viszony azonban mindvégig kifejtetlen marad.

\footnotetext{
263 Nem mellékesen pedig fontos közköltészeti elöfordulásait is regisztrálja a Csudálatos nagy bánatja szívemnek... kezdetü énekben (RMKT XVII/3, 26. sz.). Ennek készítője a Balassa-kódex ún. mostani poétái közül való. Vö. BóTA, i. m., 11. A kérdésröl ld. még a Szerelmesitöl vált... kezdetü éneket tárgyaló fejezetet.

${ }^{264}$ JANKOVITS, Soliloquium és oratio, 217.
} 
Ennek ellenére a viszontlátás részletezése mégis két versszakot vesz igénybe; tkp. a költemény második felének egészét - ebből következik, hogy a Bóta által (a Madách-Rimaykódexekhez egyébként feltünően közeli forrásokban) regisztrált zárlattípus nem mindig szorítkozik egystrófányi terjedelemre. ${ }^{265}$

4. Áldott lesz az óra, melyben öt láthatom,

És én szerelmemet nekije vallhatom,

Megvigasztalhatom,

$S$ vigasztalásával magam nyugodhatom.

A körülményességet az indokolhatja, hogy a hangsúly nem elsősorban a távollét (amúgy jelentőségteljesen egy similitudo által relativizált) térbeli aspektusára esik, hanem az azzal elválaszthatatlanul összetartozó temporalitásra. Úgy látszik ezért, hogy amiről az ismeretlen szerző a maga mértéktartó módján leginkább számot ad, az a szerelmes állapot minden momentumában különleges (speciale) ideje.

\section{Összegzés}

A korábbi szakirodalom álláspontjából kiindulva az Oly nehéz nem látnom elöttem járnia... kezdetủ éneket Rimay János hiteles szerelmes versei közül a Balassa-kódexből ismert sorrend szerinti második darabbal (Ne csudáld szívemet...) hasonlítottam össze. Ez a komparáció a következő eredményekre vezetett.

Rimay versében a megszólítás figurái különféle müfajokat látszanak konnotálni: a szöveg szimultán tükrözi a verses levél ill. a soliloquium egyes jegyeit. Diszkrét pragmatikai alakzatokat máskülönben a vizsgált alkotás is hordoz, csakhogy abban a kérés, akárcsak az ígéret kizárólag feltételes módban, és soha nem imperatívuszban fogalmazódik meg.

A legfontosabb különbség a két mü között ezért az, hogy a Rimay-verssel szemben az Oly nehéz nem látnom... beszélője nem bízza közvetlenül a szövegre, hogy kedvese vigaszt leljen abban (ami a levél funkciója volna), és hogy ettől végre maga megnyugodjék (ami pedig a magánbeszédé): amiért fohászkodik, az mindösszesen egy újabb kedvező pillanat lehetősége.

\footnotetext{
265 Az utolsó sor esetében Radvánszky olvasatát (,,S vigasztalásával magam nyugoszhatom”; RIMAY János
} munkái, 29.) nem tartom megalapozottnak. 


\section{Hárfa ...at valahova juthat, mindent csendesít... 266}

Az ének négy strófából áll, s azok közül az első több helyen hiányos. ${ }^{267}$ Ennek oka ugyanaz, mint a füzet e harmadik levelének színén elhelyezkedő vers (Látod ez gyöngyszemet...) esetében; a cím (Más) és az első szó (Hárfa) ez esetben is az előző lap aljáról maradt ránk. ${ }^{268}$ Hogy a verzó tetejére írott szöveg mégsem azzal szimmetrikusan sérült (tehát a strófa tagmondatainak elején), hanem elszórtan, az abból adódik, hogy Madách eddig tapasztalható gyakorlatától elérően az egyes szakaszokat egybefüggően, nem pedig sorokra tagoltan másolta be - mely jelenség nyilvánvalóan nem független attól a ténytől, hogy a gyüjtemény sorrendjében e tárgyalt vers az első, amelyik Balassi-strófákban íródott.

1. Hárfa ....at valahova juthat, min ... csendesit,

Fenye természetet, meg... szivet ront, változtat, szeligyít,

....ak közt félelmet, népek közt szerelmet ez gyakran szerez, épít.

Könnyű észrevenni, hogy a strófa legszembetünőbb szintaktikai eszköze az igehalmozás, melyet - ahogy azt dolgozatom során már többször idéztem ${ }^{269}$ - Bóta László e korpusz esetében „stílusdetermináló” erejünek tart, s ezért a szerző kilétének kérdésében Rimay János mellett teszi le a voksát. Indoklása szerint „Rimay, akárcsak mestere, a Magyar Amphion, nagy rutinnal csillogtatja ezeket a nyelvi szépségeket. ${ }^{, 270} \mathrm{Az}$ antonomázia eredetére Bóta persze nem tér ki, hiszen köztudott, hogy az Rimay Balassi Bálinthoz címzett Elogiumának ötödik sorából való: ${ }^{271}$

Vagy Syren, vagy Circe, vagy Magyar Amphión...

Rimay-kiadásában Ács Pál ehhez a lokuszhoz az alábbi jegyzetet füzi: „E metaforákkal határozza meg Rimay Balassi költészetének lényegét: csoda, a poeta natus, a született költö

\footnotetext{
${ }^{266}$ A tizenöt szerelmes vers vizsgálata során eleinte szinte kizárólag az foglalkoztatott, hogy azok retorikai szempontok alapján hogyan pozícionálhatóak az arisztokratikus és a populáris regiszter között. Az ezzel kapcsolatos hipotéziseimmel első ízben e vers ürügyén - még szegedi doktorandusz hallgatóként - a pécsi Csütörtökeste tudományos közössége elött volt alkalmam elörukkolni. Azóta is hálás vagyok a kritikáért, amelyben akkori házigazdáim, Jankovits László és Pap Balázs részesítettek. A következőkben elsősorban nekik próbálok végre érdemleges viszontválaszt adni.

${ }^{267}$ Kritikai kiadása: RMKT XVII/12, 52. sz.

${ }^{268} \mathrm{Ld}$. a vonatkozó fejezetet.

${ }^{269}$ A Semmi állat nincsen ... ill. az Egy szép rózsaszálat ... c. fejezetekben, ld. ott.

${ }^{270}$ BÓTA, i. m., 14. Kiem. tölem. B. P.

${ }^{271}$ A sor lehetséges értelmeiröl ld. BALÁzs-HAJDU, JANKOVITS, PAP, i. m., 22-23.
} 
csodája, magával ragad, átformál, és a semmiből alkot világokat."272 Mindez számunkra azért érdekes, mert a tárgyalt ének kissé foghíjas bevezetésében éppen egy olyan mitológiai alak körülírása történik meg, akire szintén ráillenék ez a leírás; nevezetesen Orpheuszé. Ennek apropóján pedig nem tủnik hiábavalónak elidőzni afölött, hogy a fenti halmozás miért éppen az adott elemekből tevődik össze.

Orpheusz személye Rimay (hiteles) költészetében egyáltalán nem kerül szóba, ahogy egyébként Balassiéban sem. Ha azonban körültekintünk a 17. század szerelmi lírájának emlékei között, észrevehetjük, hogy a Balassi-vershagyomány popularizálódásában kitüntetett szerepet játszó Vásárhelyi daloskönyv két ízben is említi. Elsőként a Keserves panaszim mi haszna, hogy tészem... kezdősorú énekben: ${ }^{273}$

4. Írják, hogy Orpheusz ékes lantalással Mindenféle vadat szelidithet azzal,

Sok ékes szavával,

Még az kösziklák is sírtak könnyhullással.

$$
[\ldots]
$$

6. De te, fene vadam, ennyi hivásomra, Gyakran édesgetö versem szavaira S könnyhullatásimra, Csakjó szót sem adál sok óhajtásimra.

Másodszor pedig abban, melynek versfői - szintén Bóta László gyanúja szerint - talán a Pogrányi családnevet hordozzák (Piros rózsa színü, sok vigasság szerzö kegyes istenasszonyok... $\left.{ }^{274}\right)$.

8. Orpheusz halálát, rettenetes kénját siratják még az fák is, Szüzek, szép virágok, valakik hol vadtok, sirassatok engem is, Söt édes szerelmem, ki ma elhagysz engem, bánkódjál te magad is.

A kettő közül az elsőként idézett részlet azért fontos kontextusa a tárgyalt versnek, mert az Orpheusz-monda egyazon jelenetét dolgozza föl. Továbbá azért is érdekes, mert mint argumentum összecseng Balassi - már érintett ${ }^{275}$ - Ötvenhetedik c. versének alábbi soraival (10-11. ill. 16-17.):

\footnotetext{
272 RJÍ, 289.

${ }^{273}$ RMKT XVII/3, 150. sz.

${ }^{274}$ RMKT XVII/3, 194. sz., 8. vsz. Az akrosztichonról: Uo, 642. Itt jegyzem meg, hogy - szempontjainktól nem teljesen függetlenül - Dézsi mindkét verset Balassiénak tulajdonítja, vö. BALASSA Bálint minden munkái, 243, 265.

${ }^{275}$ Bővebben ld. a Ne gondold, szerelmem... kezdetü éneket tárgyaló részfejezetet.
} 
Szép sólymok, vad rárók, kiket madarászok tanitanak, viselnek,

Bánással, tartással, szóval, kiáltással, szelídek, kézre jünek...

$[\cdots]$

Téged penig, sólymom, én édes vad ráróm, az én sok kiáltó szóm

Kezemre nem híhat...

(A képalkotási technika, látjuk, azonos. Az ott antikizáló, emitt középkorias toposzokból felépülő bestiális metaforika ráadásul mindkét helyen oxymoronná torzul, mivel a megszólított hölgy nem hajlik a domesztikációra - ez alighanem a retorikai adeptio fogalmát meríti ki).

A Rimay-életmüben mellőzött Orpheusz mellett Kirké szintén adatolható a Vásárhelyi daloskönyv anyagában (két énekben is), a Szirének pedig a Gosztonyi-kódex verseiben jelennek még meg. E közköltészeti alkotások annyiból érdemesek a szóra, mert a nevezett istennőt mindenek előtt varázsereje okán méltatják, a Sziréneket pedig egyhangúlag hazug szavú csábítóként jellemzik. ${ }^{276}$ Ezeknek a lényeknek mint közhelyes példák alanyának tehát reflexív (költői tevékenységre utaló) aspektusa Rimay idejében - szemben Orpheusszal - a jelek szerint még nincsen.

Befejezve a sort: Amphión neve más kora újkori magyar nyelvü forrásból nem ismert. ${ }^{277}$ Vagyis Rimay háromtagú felsorolásából kettő keresettségét az mutatja, hogy ilyen (egyáltalán: pozitív) összefüggésben eladdig nem volt szokás szerepeltetni, a „magyar Amphión" titulus frappáns voltát pedig jól mutatja, hogy az a legutóbbi időkig is félreérthetetlen jelölője Balassi Bálintnak. ${ }^{278}$

\footnotetext{
${ }^{276}$ Kirké személye az Egy keserves, jóktól fosztatott szegény rab... (RMKT XVII/3, 43. sz) ill. az Ajak vérén termett sugár liliomszál... (Uo., 157. sz.), a Sziréneké pedig Az Florentinának, Altades lányának vagyok én seregéböl. (Uo., 106/II. sz.) kezdetủ versekben idéződik meg.

${ }^{277}$ Érdekes módon annak ellenére, hogy - amint arra Jankovits László felhívta a figyelmemet - Amphiónról esik szó Horatius Ars Poeticájában is, méghozzá Orpheusszal egy lapon említve, vö. 391-396. sorok: „Silvestris homines sacer interpresque deorum / caedibus et victu foedo deterruit Orpheus, / dictus ob hoc lenire tigres rabidosque leones; / dictus et Amphion, Thebanae conditor urbis, / saxa movere sono testudinis et prece blanda / ducere, quo vellet.” Muraközy Gyula fordításában: „Emberevésröl, rút ételröl hajdan az erdők / népét isteneink szent papja beszélte le: Orpheus; / innen a hir, hogy oroszlánt, tigrist tett kezesekké. / Amphión - mondjákThebaet alapitva varázsos / énekkel meg a lant erejével vitte a sziklát, / merre akarta." (Quintus HoRATIUS Flaccus Összes versei, szerk. BORZSÁK István, DEVECSERI Gábor, Bp., Corvina, 1961, 594-595.) Márpedig e mü ismeretével szélesebb körben számolhatunk, minthogy az a korabeli Magyarországon az iskolai oktatás részét képezte.

${ }^{278}$ Szilasi László egy korábbi tanulmányában felidézi az antikvitásban e mitológiai alakokhoz füződő komor történeteket, megkérdőjelezve, eleve tekinthetjük-e dicséretnek az Elogium antonomázia-sorát. „,Az eddigiek alapján hajlandó vagyok azt mondani, hogy a szirén, Kirké és Amphión metaforáival Rimay meghatározza Balassi költészetéröl kialakitott véleményének másik, kevésbé napsütéses lényegét is: Balassi olyan szerzö volt, aki a müvészetek istenének templomára támadt, büntetése jogosan volt: halál, s e szerzö olyan szövegeket irt, melyek lealacsonyítják, elállatiasitják a kevéssé kitüntetett társakat, s megölik a gyengéket. Ezért aztán
} 
Varga Imre az első strófát így annotálja a kritikai kiadásban: „A Peőngeszeét koboznak (58. sz.) kezdetü versben is szó van a hárfáról, mely "gyönyöröséget hoz«. "279 Ez az ének pedig tudvalevőleg a Madách-Rimay-kódexek egyik legelevenebb költeménye. Szerzését Madách Gáspártól - a modern szövegkritika permanens gyanakvására alapozva ${ }^{280}$ - Bitskey István perelte el mintaértékủ elemzésében, arra is ügyelve, hogy a feltünően színvonalas poémát ne engedje meg Rimaynak tulajdonítani. ${ }^{281}$ A rövidség kedvéért most csak a vers legjobban idevágó harmadik versszakát közlöm: ${ }^{282}$

Hárfa, lant zengése gyönyörüséget hoz,

Hegedünek hangja lakodalom házhoz,

Sipszónak az szava jó az serkorcsmához;

De koboz pengése elmetörödést hoz.

Zemplényi Ferenc Bitskey attributív megállapításaival szemben nem fogalmaz meg ellenvetéseket, a figyelmet inkább az ún. Balassi-kör eddig e szempontból kellőképp nem vizsgált tagjaira irányítja - minthogy a verset szisztematikusan végigkíséri az egyes hangszerek léthelyzetekkel való azonosítása, ezért az szerinte mint tökéletes concetto értékelhető, s arra csak egyetlen további példa akad a magyar 17. század költészetében, mégpedig Rimay Kerekded ez világ... kezdetű verse. ${ }^{283}$

Ezért is tartom szükségesnek megemlíteni a másik olyan, a tárgyalt vershez szintén közeli szöveghelyet, amelyben hárfa ábrázolódik: Rimay János Epicédiumának Bocsásd Szent Lelkedet... kezdetü énekéből a tizenkettedik strófát, mely lényegében Balassi Bálint harci vagy halotti zászlajának ekphraszisza. ${ }^{284}$

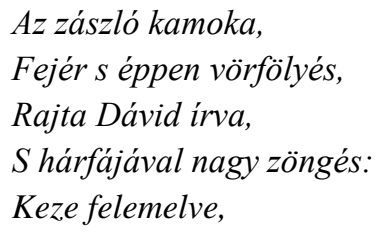

elzárandók elölük." SZILASI László, Hibbe(csúf): Rimay János Balassi-elogiuma = HÁRs Endre, Sz. L., Lassú olvasás, Szeged, Ictus-JATE, 1996 (deKOn-könyvek, 7), 199-200.

${ }^{279}$ RMKT XVII/12, 735.

${ }^{280}$ Magyar költészet Bocskaytól Rákócziig, s. a. r. EsZE Tamás, KISS József, KLANICZAY Tibor, Bp., Szépirodalmi, 1953 (Magyar Klasszikusok) 11, 64.; RÖM, 165.; VARGA, Tallózások Madách Gáspár körül, 69.

${ }^{281}$ BITSKEY István, Pöngését koboznak $\ldots=$ A régi magyar vers, szerk. KoMLOVSZKI Tibor, Bp., Akadémiai, 1979 (Memoria Saeculorum Hungariae, 3), 225-234. Bitskey (negatív) attribúciós érvelése szerint az ének reménytelenségben megnyugvó hangütése idegen Balassi vitézi költészetétől, de keresetlensége nem vall Rimayéra sem, stiláris komplexitása viszont messze meghaladja a hiteles Madách-alkotások színvonalát.

${ }^{282}$ Kritikai kiadása: RMKT XVII/12, 58. sz.

${ }^{283}$ ZEMPLÉNYI, Müfajok reneszánsz és barokk között, 140, 142.

${ }^{284}$ Vö. SZENTMÁRTONI SZABÓ Géza, Balassi Bálint halála = RiMAY János, Epicédium a Balassi fivérek, Bálint és Ferenc halálára, szerk. Ács Pál, Bp., 1994, 79. 
Szive kiterjedve,

S abban buzgó könyörgés.

Az eddigi citátumok zöme alátámasztani látszik egy olyan koncepciót, miszerint a bibliai Dávid hangszere a hárfa (tkp. a kinnór), a mitológiai Orpheuszé pedig a lant (tkp. a lyra) lenne - csakhogy ez az idea nagyrészt a régi korok terminológiai szabadságának eredménye. A kinnórt ti. már a Vulgata is gyakran fordítja lyrának v. citharának, régi bibliafordításaink pedig - kiterjesztve a szinonímiát - a hárfa, lant, citera, sőt hegedü szavakkal ültetik át azt magyarra. ${ }^{285}$ Ez megmagyarázza, hogy a szövegben miért nevezik hárfának Orpheusz a hagyomány szerint saját fejlesztésű, máskülönben az ún. járomlantok családjába tartozó eszközét. (NB. a kinnór is az.) A második strófa második sorában viszont egy zavarba ejtő szintaktikai alakzat tovább bonyolítja az ügyet:

\footnotetext{
Orpheusz, ím látod, sokféle állatot magához mint szoktatott, Erdök közt bujdosva, járván idestova hogy hegedült és lantolt, Nevének nagy hire terjedvén messzire miközénk is elhatott.
}

Tudnivaló tehát - számomra elsősorban Király Péter kitűnő monográfiájából ${ }^{286}$-, hogy a régi magyar (és általában az európai) zenetörténeti érdekű emlékek ritkán konzekvensek a pengetős v. egyáltalán a húros hangszerek megnevezésében. E praxis egyik legirritálóbb vonása éppen az, hogy ha esetenként a források különbséget is tesznek közöttük, az eltérések mibenléte egzakt leírás hiányában ill. az elementáris kiszámíthatatlanság miatt csak igen ritkán határolható körül. Ahogy Király fogalmaz: „, a kora középkortól fogva bizonyos fokig mindig is egyéni elbírálás, szókincs és müveltség függvénye volt, hogy valaki a saját korának egy-egy hangszerére az antikvitás melyik kifejezését használta”, s ez „megfigyelhető a nemzeti nyelvek hangszerneveinél is. "287 Ami pedig a dolog módszertani vetületét illeti: „a XVI-XVII századi dokumentumokban rejlö muzsikus-megjelölések és hangszernevek értelmezéséhez nincs - és talán nem is lesz - teljesen biztos recept. [...] Számítanunk kell tehát arra, hogy míg egyes esetekben a válasz magától adódik, és másoknál még viszonylag könnyen megadható lesz, addig megint másoknál az teljesen bizonytalan marad. "288

A fentiek értelmében tehát a szóban forgó függvény egyes összetevőivel (,,egyéni elbírálás, szókincs és müveltség”) jelen esetben is számolnunk kell. Az egyéni elbírálás

\footnotetext{
${ }^{285}$ A kérdésröl bővebben ld.: PÁviCH Zsuzsanna, Az ószövetségi zene gyökerei, szakrális és világi kibontakozása, hatása az európai müvelödésre, PhD-értekezés, Bp., 2008.

${ }^{286}$ KIRÁlY Péter, A lantjáték Magyarországon a XV. századtól a XVII. század közepéig, Bp., Balassi, 1995, (Humanizmus és Reformáció, 22), 23-30.

${ }^{287}$ Uo., 23.

${ }^{288}$ Uo., 30.
} 
alighanem most is - akárcsak az iménti, Orpheusz megjelenítését kontra meg nem jelenítését feszegető gondolatmenet esetében - a szöveg poétikai funkciójához köthető: a költő egy állítmány helyett (pl. az általánosabb jelentésű muzsikál) helyett választ két szinonim igei metaforát (hegedül és lantol), lévén ez ráadásul metrikailag is kielégítő megoldás. Ami viszont a szókincset illeti: közel sem biztos, hogy e körülírást (circumlocutio) kizárólag a választékosság igénye hívja életre, ti. a hárfázik igét mint olyat a Magyar nyelvtörténeti szótár és a TESz is csak a 18. századból tudja adatolni (hárfál alakban), vagyis megeshet, hogy az jó másfél évszázaddal korábban egész egyszerủen nem létezett. ${ }^{289}$

De már abban sem lehetünk maradéktalanul biztosak, hogy ez a szóhasználat csakis körülíró lehet. Jóllehet a deiktikus „ím látod” fordulat (4. sor) vonatkozhat általában a szövegvilág elemeire is, mégis különös csengést ad neki az a körülmény, hogy a korabeli metszeteken Orpheuszt éppúgy ábrázolják pengetős, mint vonós zeneszerszámok virtuózaként. (Vö. 1. és 2. sz. ábra. ${ }^{290}$ )

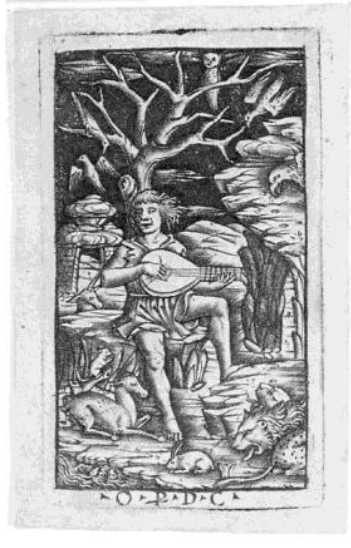

1. sz. ábra.

Orpeusz lantjátékával megszelídíti az állatokat

(Peregrino da Cesena, 1500-1520 k.)

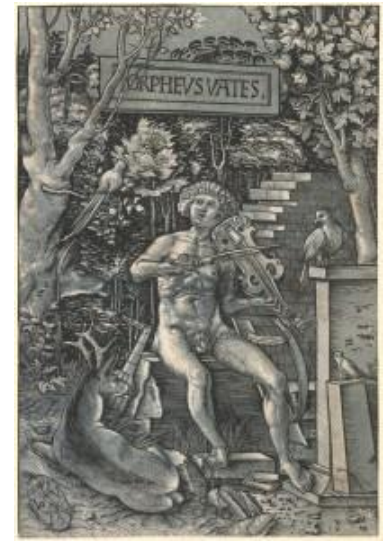

2. sz. ábra Orpheusz

(Hans Wechtlin, 1512)

Vagyis meglehet, hogy a szerző nemcsak hogy a hangszerek között tudott valamiféle elemi különbséget tenni, de azzal is tisztában volt, hogy példaképe kezében hol az egyikkel, hol a másikkal mutatkozik - s ez esetben a két igét éppen hogy nem szinonim értelemben szándékozott használni.

\footnotetext{
289 A problémafelvetésért szintén Jankovits Lászlónak tartozom köszönettel.

${ }^{290}$ A képeket a Metropolitan Museum és az Albertina honlapjáról töltöttem le 2016. január 30-án. http://www. metmuseum.org/collection/the-collection-online/search/363363; http://www.albertina.at/en/exhibitions/future?ausstellungen_id=1353999798741
} 
Utoljára maradt az egyéni műveltség kitétele. Pap Balázs Históriák és énekek c. értekezésének egy fejezetében (Az ismeretlen Tinódi Sebestyén) éppen a 16. századi lantosok és hegedűsök a 19. századtól kialakított osztályozásának adja átfogó és nagyon alapos kritikáját. ${ }^{291}$ A Toldy Ferenctől eredő, majd Szilády Áron, Pintér Jenő és Dézsi Lajos munkáiban kijegecesedett teória szerint ugyanis míg a lantosok az elit kultúrát képviselő dalnokok voltak, addig a hegedüsök reszortja a köznép szórakoztatása lehetett. (Ami az ebből fakadó medialitás- és müfajtörténeti téveszméket illeti; nos, azok nem tartoznak e tárgyhoz, ez ügyben különben is csak Pap Balázst tudnám referálni mély szimpátiával.) Az elméletet később Réthei Prikkel Marián revideálta egy hosszú tanulmányban, melynek most csak egyetlen tézisét ragadnám ki; jelesül hogy a hegedüs és a lantos kifejezések - Réthei Prikkel ebben többek között Szenci Molnár Albert szótárának 'fides' címszavára is hivatkozik - csereszabatosak. ${ }^{292}$

Pap e fejlemény lényegét találóan így összegzi: „,Réthei Prikkel a következetlenségböl a megkülönböztethetetlenséget olvassa ki. "293 Viszont abbéli véleményével, hogy „, a hegedüs és a lantos nem jelöl különbözö versszerzöket, abban Réthei Prikkelnek teljesen igaza van”,"94 már nem érthetek feltétel nélkül egyet. Méghozzá azért nem, mert attól, hogy a modern kor irodalom- ill. zenetörténészei számára e két típus megkülönböztethetetlen, az eddigiek fényében még egyáltalán nem válik szükségszerüvé, hogy a korai újkor müvelt embere szerint is az lett volna.

Medialitás- és müfajtörténeti kérdésekre ehelyütt változatlanul nem áll módomban kitérni, a jelenség irodalomszociológiai érdekét tekintve azonban nem tudom figyelmen kívül hagyni azt a Király Péter szolgáltatta - kétségkívül német szakirodalomra támaszkodó adalékot: „...egyértelmü a XVII. századi németalföldi festmények tanúságtétele is. Ezeken ugyanis a lant a viola da gambával és a virginállal együtt a polgári környezetet ábrázoló életképeken fordul elö, míg a parasztoknál többnyire hegedüt, dudát, furulyát és cisztert láthatunk. „295 Sietve szögezem le, mi sem áll tőlem távolabb, mint bármiféle légvárak restaurálásának a szándéka: a szórványos, gyakran közvetett és esetenként távoli információk alapján nem állíthatom, hogy a magyar 17. században bizonyosan elkülönült volna e két hangszerhez köthető feladatkör - de ennek lehetőségét éppen ugyanezekből az okokból kifolyólag nem tudom mindenestül kizárni sem.

\footnotetext{
${ }^{291}$ PAP Balázs, Históriák és énekek, Pécs, Pro Pannonia, 2014, 189-195.

${ }^{292}$ A szó jelentését Szenci Molnár az alábbi értelemben adja meg: „Fides, Fidis. g. f. 3 declin. Hegedő húr, Húr. Item Lant, Hegedö." SZENCI MOLNÁR Albert, Dictionarium Latinoungaricum, Nürnberg, 1604, a fakszimile szövegét közzéteszi KöSZEGHY Péter, Bp., Akadémiai, 1990 (Bibliotheca Hungarica Antiqua, XXV), O4v. Idézi: RÉTHEI PRIKKEL Marián, A régi magyar énekmondók [II], EPhK, 1917, 207.

${ }^{293}$ PAP, Históriák és énekek, 193.

${ }^{294}$ Uo., 194.

${ }^{295}$ KIRÁLY, i. m., 12-13.
} 
Ráadásul ebben a kérdésben az egyetlen olyan magyar nyelvü ének is homályosan fogalmaz, amely alkalmasint ilyen irányú taxonómia igényét is tükrözni látszik, vagyis az azonos forrás őrizte Pöngését koboznak... kezdetü. Az idézett strófa szintaktikai felépítéséből nem állapítható meg egyértelműen, hogy szerzője az első két sorban él-e közöléssel (a köznyelvi forma ez esetben így hangoznék: „Hárfa, lant zengése, hegedünek hangja gyönyörüséget hoz lakodalom házhoz”), vagy az első sor önálló tagmondatot képez, és a zeugma épp a másodikat és harmadikat köti össze (vagyis azok melléknévi állítmánya volna közös: „Hegedünek hangja lakodalom házhoz, Sípszónak az szava jó az serkorcsmához.”)

Szilasi László - e költeményben is Balassi költői nyelvének utóéletét kutatva mindenesetre kizárólag az utóbbi tagolással kalkulál. ${ }^{296}$ Szilasi Zemplényivel szemben úgy látja, hogy abban a léthelyzetek valójában nem azonosítódnak, hanem helyettesítődnek az egyes zeneszerszámokkal, méghozzá a hangszer-hang-hangulat-hely fogalomkör metonimikus láncolatát követve. A müfajiság szempontjából pedig azt a figuratív eljárást tételezi relevánsnak, hogy e sorozatok rendre elliptikusan képződnek meg. A harmadik strófában pl.: „a hárfa és a lant zengése gyönyörüséget hoz (hang - hangulat - [...]). A hegedü hangja a lakodalmas házhoz, a sípszó szava a serkocsmához jó (hang-[...]-hely). A koboz pengése az elme törödését hozza (hang-hangulat-[...])."297 Majd a concetto kívánalmait tovább vizsgálva megállapítja, hogy a többi versszak észrevehetően ugyanezt a metódust variálja, csak éppen minden esetben eltérő mintázat szerint. Az interpretáció tehát éppen azon részeredménynek a belátásával tud kiteljesedni, hogy ez a sensus litteralis szintjén nagyfokú egyszerüségre törekvő, ezzel együtt azonban bámulatos retorikai tudatossággal kidolgozott (nem mellesleg a 17. századból név szerint ismert versszerzőkhöz úgyszintén nem köthető) alkotás két különböző funkcióba sorolja a lant és a hegedű szavát - igaz, a komplex problémakör valóban nem modellezhető pusztán az elit és az alsó rétegek kulturális igényeinek dichotómiájával.

Térjünk végre át a vers második felére, ami retorikai szempontból több jelentős fordulatot tartogat: a demonstratív közlést felváltja a tanácskozó beszéd, konkretizálódik a beszédhelyzet célközönsége, és az is tisztázódik, hogy az előbbiekben felelevenített toposz példázatként (exemplum) értendő.

\footnotetext{
${ }^{296}$ SzILASI, A sas és az apró madarak, 48-51.

${ }^{297}$ Uo., 49.
} 
3. Szerelemben menyek vadtok ki kemények, Orpheuszhoz álljatok, Az nála megszokott fenyevad állatok példájára álljatok,

Értetek megepedt bús, szerelmes szivet vidám kedvvel lássatok.

4. Két ellenkezö vad soha meg nem alkhat, nincsen köztök egyezés, Így az igyenetlen erkölcsben, termetben ritkán vagyon szelédség, Bár egybe kötözd is, kiforr köztök mégis mind méreg, idegenség.

Vegyük sorra ezeket. A rábeszélés (suasio) a szerelmi költészet kézenfekvő beszédneme. Alkalmazását az udvarló versekben nyilván az elutasítástól való félelem ill. a viszonzás reménye indokolja; a kauzális (azon belül is: lélektani) argumentáció ennek megfelelően a rossz elkerülését és/vagy a jó elérését veszi azokban célba - láttuk, így történik ez a gyüjtemény ilyen típusú énekei esetében is. ${ }^{298}$

Ha viszont a gyüjtemény e szerelmi tárgyú alkotásai nem udvarló, hanem oktató szándékúak (s e tekintetben a tárgyalt vers a Nagy példát adhatok énrólam mindennek... és a Ki-ki terhét vállán közülünk viseli... kezdetủekkel rokon), azokban kizárólag a rossz elkerülése fogalmazódik meg célként. ${ }^{299}$ A fenti rezignált s mégis szinte fenyegető élű sorok is arra figyelmeztetnek, hogy ha az eltérő habitusú s ezért összeférhetetlen egyedek nem békülnek össze egymással - értsd ez alatt: ha egy ifjú leány képtelen az iránta érzett hevületet elviselni (tolerantia) - és mégis egybeköttetnek (vagyis házasságot kötnek), közös életük minden valószínűség szerint viszálykodással v. keserüséggel és ridegséggel lesz teljes.

Most tekintsük át a vizsgált korpusz didaktikus hangvételü költeményeinek főbb különbségeit. A legkiugróbb eltérés közöttük kétségtelenül az, hogy amíg a füzet első felében rögzített, felező tizenkettesben írott énekek (az egykorú szerelmi tanítások átlagának megfelelően) egyben moralizáló jelleget is öltenek, addig vizsgálatunk jelenlegi tárgya tökéletesen nélkülözi az etikai megfontolásokat $-\mathrm{s}$ e vonatkozásban különösen az a nyugtalanító, hogy ez kizárólag hölgyek épülésére kíván szolgálni.

Végezetül. A Nagy példát adhatok énrólam mindennek... és a Ki-ki terhét vállán közülünk viseli... kezdősorú énekek elemzése annak belátásához vezetett, hogy az azokban megkreált példaérték nem valódi (vagyis tárgyon kívüli) exemplum bevonásával eszközlődik, hanem személyi érvekre (jobbára a beszélő korábbi tetteire és mondásaira) hagyatkozva.

Az a példa ugyanakkor, mellyel a Hárfa ...at valahova juthat... kezdetü vers szerzője operál, különösen illik a tárgyához, méghozzá azért, mert alkalmas lehet egy árnyaltabb, s

\footnotetext{
${ }^{298}$ Elsősorban a Ne gondold, szerelmem... és a Szerelemtül csak kár... kezdetủ énekekre gondolok, ld. a vonatkozó részfejezeteket.

${ }^{299}$ Csak a didaktikus szándék közös, a beszédnemek már eltérőek: az előbbi rábeszélő, az utóbbi bemutató célzatú.
} 
ahogy arról jó elöre megbizonyosodtunk: reflexív jelentés megképzésére. A dalnok Orpheuszhoz állni tágabb értelemben azt is jelentheti, hogy a megszólítottaknak általában véve kellene hallgatniuk a költő szavára. A költészet meggyőző ereje azonban (ahogy arra mindezek kapcsán már Nagy Ferenc is kitért ${ }^{300}$ ) nemcsak a tartalomban, de a formában is megmutatkozik: ezzel pedig a Balassi-strófákban írott szöveg óhatatlanul megidézi a nagy előd alakját. Vajon lehet-e köze ennek ahhoz, hogy az Orpheusz név amúgy nem jelenik meg az Elogium metaforái között?

\section{Összegzés}

A versgyűjtemény tizedik, igen kiérlelt darabja az Orpheusz-mítosz azt a népszerü epizódját dolgozza fel példázatként, melyben a poéta mágikus zeneszavára békésen köréje sereglenek a vadállatok, s annak azt a tanulságot tulajdonítja, hogy a menyecskéknek is ekként kéne reagálniuk a szerelmi költészetre, másképpen nem léphetnek jól közösségre másokkal, következésképpen csakis rossz házasságnak nézhetnek elébe. Figyelemreméltó, hogy e tanításba a leghalványabb moralizáló célzat sem keveredik.

A versszövegben a zeneeszközre és annak megszólaltatására használt terminusoknak a különnemüsége (ti. hogy Orpheusz hegedült és lantolt volna egy hárfán) többféle olvasati lehetőség irányába is utat nyit. Az egyik, hogy a vers írója valamilyen oknál fogva - pl. mert a hárfajátékra nem volt még szava - abuzív körülírásra szorítkozott. Ennek valószínűségét jócskán megnöveli, hogy a legtöbb 17. századi forrás nagyfokú következetlenségről árulkodik a pengetős és vonós hangszerek megnevezését illetően. Csakhogy mivel a különbségtétel nagy néha mégis vitán felül konzekvens, ezért további eshetőségekkel is számolnunk kell. Ezek szerint a szerző nem is a halmozás (congeries), hanem a felsorolás (enumeratio) eszközével élt: vagyis nem a szinonímia lehetősége, hanem a szabatos fogalmazás kívánalma vezérelte, mert vagy különféle játéktechnikára, vagy egyenesen különféle hangszerek megszólaltatására utal - Orpheuszt ugyanis a korabeli képzőművészeti alkotások hegedűvel és lanttal felszerelve egyaránt ábrázolják.

\footnotetext{
${ }^{300}$ NAGY, i. m., 21.
} 
„Lantos, hegedüs, cimbalmos, hárfás vernek táncnótákat”301 - az ilyen és ehhez hasonló citátumok arra engednek következtetni, hogy ha az egyes zeneszerszámok említésében ki is tapintható valamiféle tudatos megkülönböztetés, az intézmények, melyekhez kapcsolódnak, indifferensek. Nos, az - éppen a kolligátumok egy további füzetében fennmaradt - Pöngését koboznak... kezdetű ének nyilatkozik radikálisan másként a korabeli gyakorlatról: eszerint az egyes hangszertípusok (egyebek mellett a lant és a hegedủ) különféle kulturális színterekhez kötődnek, és másféle közönségigényeket elégítenek ki. Mindez azonban bizonyosan túlmutat azokon a leegyszerüsítő oppozíciókon, melyekkel a 19. század végi, 20. század eleji irodalomtörténet-írásunk igyekezett megragadni e szimptóma gyökerét.

301 VARSÓczI István, Az Körösztölő Szent Jánosnak fogantatásárul, születésérül, hivataljárul, hüségérül, tudományárul, fogásairul és halálárul szép história = NAGY Sándor, Adalékok XVI-XVII. századi elbeszélö költészetünk irodalmához, VI., EPhK, 1885. 172-182. (259. sor.) 


\section{1. Ércnél, kösziklánál keménybnek vallhatnál...}

A füzet jelenlegi formájában ez a vers az első, melynek paratextusai közül (Más ill. Az én szívem gyönyörködtető szerelmesem ékes személyének kedves irására való választétel v. választételem) az utóbbi - tekintettel annak személyragozására - szerzői címként értékelhető. ${ }^{302}$ Arra már Baros Gyula is felfigyelt, hogy a válasz gyakori alapszituáció a gyüjtemény verses levelei között, egy helyütt pedig Pirnát Antal is kitér a három egymást követő, szabályszerü Balassi-strófában írott válaszlevélre, melyek sora tehát a tárgyalt költeménnyel kezdődik. ${ }^{303}$ A versforma a vizsgált anyag második leggyakoribb képlete: láttuk, a levélverseket közvetlenül megelőző ének is eszerint íródott. (Azzal együtt az is kitünik, hogy míg a három verses levél terjedelme három-három strófa, addig a Hárfa ...at... kezdetű négy strófából áll.) A beírás módja azonban egyedülálló: szemben a másik hárommal ez az alkotás kilenc sorra van tördelve. ${ }^{304} \mathrm{Ez}$ a jelenség első megközelítésben azt a lappangó sejtésünket látszik alátámasztani, hogy a füzet tartalma vegyes anyagból állt össze: eszerint a korpusz ősmásolója (vélhetőleg Madách Gáspár) különféle forrásokból szerkesztette egybe azt.

Valójában azonban ez a kérdés összetettebb. Köztudottan az ún. Saját kezü versfüzér tanúskodik arról, hogy Balassi Bálint a róla elnevezett versszakot három hosszú (tizenkilences) sorra tagolta, mely azonban tovább osztható két hatos és egy hetes ütemegységre. A strófaforma ilyetén felfogása szerint a hosszú sorok első két (hatos) kissorának összecsengése képezi a belső rímelést, a záró (hetes) kissorok pedig sorvégi rímbokrot alkotnak. Ugyanez a képlet kilenc sorban közölve már a Balassi-strófa némiképp módosult értelmezését tükrözi. Ha ugyanis a kisebb alkotóegységek mindegyike önálló verssorként jelentkezik, akkor felszámolódik a belső rímelés, a végrímek viszont egyfajta ölelkező formát öltenek. Az utóbbi elrendezés legkorábbi előfordulását Rimay Jánoshoz szokás kötni, csakhogy miután Rimaytól autográf verskézirat nem maradt fenn, ennek kialakulásáról pontos képet nem alkothatunk. Az első és egyetlen még a szerző életében

\footnotetext{
${ }^{302}$ Kritikai kiadása: RMKT XVII/12, 53. sz. A kéziratban fennmaradt cím emendálásáról ld.: BóTA, i. m., 8-9.

${ }^{303}$ BAROs Gyula, Rimay János szerelmi lyrája, BpSzle, 1906, 203.; PIRNÁt Antal, Balassi Bálint poétikája, Bp., Balassi, 1996 (Humanizmus és reformáció, 24), 100.

${ }^{304}$ Vö. Madách-Rimay-kódexek, I, 36-38.
} 
megjelent emlék, ahol ez a felosztás jelenik meg, az Epicédium ${ }^{305}$ (Vizsoly, 1596) - de már az is vitatott, hogy e kiadás mennyiben tükrözi Rimay szerkesztési szándékát. ${ }^{306}$ A tördelést tipográfiai okok is magyarázhatják, pl. hogy a keskeny szedéstükör általában az exkluzívabb kivitelü nyomtatványok sajátja. Az Istenes énekek későbbi gyakorlata eltérő: a kisméretü, de sok szöveget tartalmazó kiadványok - alighanem a helytakarékosság okán - a strófákat bekezdésekkel elkülönítve, de azon belül sortörés nélkül közlik, s jobbára következetesen kapitálissal jelzik az egyes verssorok elejét. Csakhogy már ebben is kitapintható egy olyan tendencia, mely jócskán túlmutat a szorosabb tipográfiai érdeken; nevezetesen hogy amíg a rendezetlen (bécsi, ${ }^{307}$ bártfai $^{308}$ ) edíciók a hármas, addig a rendezettek (lőcsei ${ }^{309}$ ) a kilences tagolást preferálják - igen érdekes módon nem kizárólag Rimay, de Balassi efféle metrumban kelt versei esetében is. Vagyis az Istenes énekek szöveghagyományának e két ága alapvetően másként gondolja el a Balassi-strófát.

Ezen a ponton érdemes újra feltenni azt a kérdést, hogy vajon melyik felfogást osztják tehát a füzet Balassa-strófában írott versei. Azt mindenesetre előre kell bocsátanom, hogy Madách előszeretettel kezdi a szavakat nagybetüvel akkor is, ha ezt semmilyen ortográfiai megfontolás nem indokolja; ráadásul egyes betűk esetében a kétféle (kis és nagy) karakter írásképe paleográfiailag sem különböztethető meg teljes biztonsággal: vagyis a kissorok kezdőbetű-típusainak statisztikája ügyében számolnunk kell azzal, hogy a máskülönben szolgaiként ismert másolói rutin ezúttal nagy eséllyel torzít az eredményen. Ennek belátásával közlöm most újra az eredetileg a margók között egybefüggően (vagyis nem verssorokra tördelve) lejegyzett Hárfa ...at valahova juthat... kezdetü éneket, ezúttal a kritikai kiadás betühív átiratában. ${ }^{310}$

1. Hárfa ...at walahoua Juthat, min ... chiendessit,

Fenie Termeszetet megh ... Szuvét ront, Valtoztat, Szelidgyt,

... ak kozt felelmet, nepek kozt szerelmet ez giakran szerez, éépit.

2. Orfeus, im latod, Sok fele alatot magahoz mint Soktatot,

Erdók kozt buidoswa, Iarwan ideztowa, hogi hegedult es lantolt,

Newenek Nagi hire, teriédueén meszire, mi közénkis el hatot.

3. Szerelemben, meniek, Vattok ki kemeniek, Orfeushoz alliatok,

\footnotetext{
${ }^{305}$ Vö. a modern kiadással: Epicédium a Balassi fivérek, Bálint és Ferenc halálára, s. a. r. Ács Pál, Bp., Balassi, 1994.

${ }^{306}$ SZABÓ András, A Balassi-epicédium és Rákóczi Zsigmond, ItK, 1982, 648.

${ }^{307}$ Következnek gyarmati Balassa Bálintnak istenes éneki, Bécs, 1633, fakszimile kiadás, kiad. KösZEGHY Péter, Bp., Balassi, 1994 (Bibliotheca Hungarica Antiqua XXIX) [RMNy 1599].

${ }^{308}$ Balassa Bálintnak istenes éneki, Bártfa, [1660 k.], Klösz Jakab [RMNy 2890].

${ }^{309}$ [Balassi Bálint, Rimay János Istenes éneki], Lőcse, 1666, Brewer Sámuel [RMNy 3292].

${ }^{310}$ RMKT XVII/12, 52. sz. A jobb áttekinthetőség kedvéért a kissorok kezdőbetüit félkövérrel emeltem ki.
} 
Az nála megh Sokot fenie vad alatok peldaiara alliatok,

Ertetek megh epet buss széérelmes sziuet vidám keduel lassatok.

4. Kett elenkezö Vad Soha megh nem alkhat, ninchien kóztök egiezez,

Igi az igienetlen erkolczben, termetben ritkan vagion szeledszégh,

Báár egibe kotozdis, ki forr koztok mégis mind meregh, idegensséégh.

A kérdéses helyeken csupán öt esetben lehet nagybetüt találni (beleértve az Orpheusz tulajdonnév kezdőbetűjét is). Tehát az ütemegységek kis kezdőbetűs írásmódjának aránya 79\%. A magam részéről e jelenség azon magyarázatát tartom a leginkább valószínűnek, mely szerint a reprodukció során Madách Gáspár igyekezett ugyan változtatás nélkül leírni forrása szövegét, de ebbéli szándéka ellenére legalább négyszer mégis eltért attól. Ha pedig ez a feltevésem helytálló, akkor a Balassi-strófa ilyetén rekonstruált tagolása a névadó praxisával összhangban álló hosszúsoros változatát látszik tükrözni.

A következő tételt a vizsgált ének képezi. ${ }^{311}$ Abban a sortörés tehát egyértelmüen egybeesik az ütemhatárokkal. A válaszlevél szituációjába ágyazott további két versike azonban - előlegezzük meg - az Orpheusszal példálózó költeményhez hasonlóan újfent folyamatosan, széltől szélig íródik majd be. Az alábbiakban ezért ismét a kezdőbetük elemzésével állapíthatjuk meg az énekek strófaszerkezetének mibenlétét: ${ }^{312}$

1. Szerelmessitöl valt Valoban nagi kint láát, nincz veghe keszerwenek,

Butul bagiat, eped, Almotis nem enged Vehetni két szemenek,

Ha megh enihitys, Nincz eep kedue megis, Nem kel ir bus leikenek.

2. Jgi Vagion en dolgom, Mert chiak búslakodom, Nem latwan Szerelmemet,

S. noha el tauoztam, De velem el hoztam Sziwemben Zart kepedet,

Buzgo kiwanssaggal, Niughatatlanssagall ohait lelkem tegedet.

3. Adia az io Isten, Szerenchjem lehessen, Egeszeghbe lássalak,

$\boldsymbol{S}$. te hw szerelmedben, kit Irs leweledben, Hamar találhassalak,

Te Veled beszelwén, Es neked orwlvéén Szassor chiokolhassalak!

Illetve:

1. En edes iob kezem, Toled keduen vessem, Hogi nekem aianlátod, Assoniodnak keduit, S. hozam hw Szerelmit, vjaiwal Iratod,

Vessed nem kis hasznat, Ha vele ket kariat, Niakam komiul rakatod

2. Legien Jokal aldod, Hogi hoza fogadod, S, ki mentet ketszegembwl, Mert hogi öt szerettem, .S. miatta epedtem, lathatia szemeimbeol,

Azert maár vigadok, Mert oli Hitben vagiok, Hogi megh ment Szebeimbeol.

\footnotetext{
${ }^{311}$ RMKT XVII/12, 53. sz.

${ }^{312}$ Ismét a kritikai kiadás betűhív átiratát közlöm újra. RMKT XVII/12, 54., 55. sz.
} 
3. Varion vigh örömmel, Mert enis Io keduel Megiek Sep Szemelliehez,

$S^{\prime}$ Te hozadis menten, chiokokal bekellem, Io hirt iro kezehez,

Hidgie bizoniossan, hogi en minden modon Sabom magam keduihez.

A kapott eredmény - látjuk - az előző alkotásból kimutathatóval fordítottan arányos: a Szerelmesitöl vált ... kezdetủ énekben a kissoroknak csupán 16\%-a, a Szerelmese jobb kezének írását köszönti címüben pedig 22\%-a kezdődik kisbetủvel. Vagyis a tárgyalt versnek valójában csak a tördelése kivételes, de amellett nemcsak hogy tematikai, hanem strofikai vonatkozásokban is tökéletesen összeillik a másik kettővel. Az is könnyen elképzelhető, hogy a másoló visszatérése a Balassi-strófa kipróbált, egybefüggő beírásához ez esetben is szimpla helytakarékosságnak tudható be.

Túl azon tehát, hogy a kolligátumok e füzete egynél több forrásból táplálkozhat, a fenti észrevételekböl bizonyos kritériumok teljesülése esetében az is következik, hogy ezek a források különböző szerzők műveit tartalmazzák. Ha feltesszük ugyanis, hogy Madách Gáspár szerzői autográfokból dolgozott, vagy pedig olyan kéziratokból, melynek valamennyi másolója szintén az összöveg változatlan reprodukciójára törekedett, akár a következő állítást is elfogadhatjuk: akárki szerezte a Madách-Rimay-kódexek verses leveleit, az a Balassistrófát bizonyosan mint kilencsoros egységet képzelte el, szemben a Hárfa ...at valahova juthat... kezdetủ ének költőjével - és végső soron alighanem Balassi Bálinttal. ${ }^{313}$

A korpuszról írott tanulmányában Bóta László a tizenöt verset ugyan kivétel nélkül igyekszik Rimay Jánosnak visszaperelni, de azon belül is föltűnő terjedelmi és tartalmi egynemüséget érzékel az első valamint a hatodiktól a tizenötödikig számított énekek között. Ez a gondolatmenet azonban néhány részletében csak kevéssé tünik konzekvensnek. A versek hosszát illetően ti. Bóta azzal érvel, hogy a kiválasztott poémák strófaszáma három és öt között van, s ezt csak a két töredékesen fennmaradt ének haladja meg, lévén azok még így is kilenc ill. nyolc versszakot tesznek ki. Ez a megállapítás önmagában is pontosításra szorul. Az az ének ti., amelyik kilenc szakaszból áll (Ne gondold, szerelmem...), egyáltalán nem biztos, hogy töredékes. ${ }^{314}$ Amelyik viszont ténylegesen töredékes (Örülj immár, lelkem), az

\footnotetext{
${ }^{313}$ Itt jegyzem meg, hogy az értekezés munkahelyi vitája során Bognár Péter kétkedésének adott hangot e megállapításom érvényességét illetően. Szerinte ugyanis még csak egynél több forrást sem szükséges feltételeznem a fenti jelenség magyarázatához, amennyiben az tükrözheti pusztán Madách Gáspár a kváziizometrikus Balassi-strófa lejegyzésének mikéntje fölötti bizonytalanságát is. (A kvázi-izometrikus strófaképlet fogalmát ld.: HORVÁTH Iván, Történeti rétegek a XVI. századi magyar metrumkincsben, ItK, 1989, 194.). Meglehet, igaza van: elvileg ezt a lehetőséget sem zárhatjuk ki. Ugyanakkor az általam kimutatott eltéréseket még mindig elég szignifikánsnak gondolom ahhoz, hogy a saját hipotézisemet tartsam valószínübbnek.

${ }^{314} \mathrm{Ld}$. a vonatkozó fejezetet.
} 
valójában a hatodik strófa őrszavával szakad meg. ${ }^{315}$ Nyolc versszak terjedelmű ugyanakkor a csonkulás után következő, de egészében ismert Beborult, fölhözött, bánat hozó egem... kezdetű alkotás. ${ }^{316}$ Ráadásul az említett intervallumba (3-5 vsz.) a negligált versek bármelyike beleillene. $^{317}$

Ami a tartalmi homogenitást illeti, Bóta ezt az alábbiak szerint határozza meg. „, $A M-$ $R$ kódex szerelmes versei is egy ilyen kedvesétől távol élö boldog szerelmes érzéseiböl fakadnak ${ }^{, 318 ~-~ e ́ r t s d ~ m i n t ~ R i m a y ~ J a ́ n o s ~ N e ~ c s u d a ́ l d ~ s z i ́ v e m e t . . . ~ k e z d e t u ̈ ~ e ́ n e k e ; ~ v a g y i s ~ a ~}$ szituációk azonossága is erősítené a reattribúció jogosságát. A tanulmányban később ez a következő tipológiai jellegü (korábban már idézett) észrevételével egészül ki: „A szerkesztés és a hangvétel közvetlensége arra mutat, hogy ezek a versek afféle szerelmes leveleknek, üdvözleteknek készültek, ebböl a funkciójukból magyarázható tömörségük, meghitt, bensöséges líraiságuk. ,319

Nos, ha Bóta tehát az összetartozás zálogát a levél-funkcióban látja, s azt kiterjeszti a kedvest invokáló, ill. a tőle való távollét felett kesergő megnyilatkozásokra, a felosztásban véleményem szerint - még így is maradnak tisztázatlan státuszú versek. A magam részéröl ugyanis csak nehezen tudnám rekonstruálni azokat a kritériumokat, amelyek mentén a Hárfa ...at, valahova juthat... kezdetü beleesik a kijelölt tizenegy énekbe, a Bírja bár akárki... viszont kimarad.

Tegyük most próbára Bóta állásfoglalásának érvényességét. Visszatérve a dolgozatom elsődleges érdeklődési köréhez, a következőkben a tárgyalt ének tüzetes olvasatának eredményeit összegzem. Abban a nyitó versszak mint bevezetés a jóakarat (benevolentia) felkeltésére irányul. A lírai alaphelyzetnek (causa) megfelelően a beszélőnek arról kell meggyőznie kedvesét, hogy érzéseiket a távolság nem tompíthatja. A személyi érveket tehát helyből és (lélektani) okból merített tárgyi argumentáció egészíti ki; de a szóban forgó hipotézist elsősorban mégis a szöveg létrehozásának gesztusa teszi evidenssé.

1. Ércnél, kösziklánál

Keménybnek vallhatnál,

Ha neked nem felelnék,

És minden irt betüt,

Ki elmédbül merült,

\footnotetext{
${ }^{315}$ Ld. a vonatkozó fejezetet.

${ }^{316}$ Ld. a vonatkozó fejezetet.

317 Tekintve, hogy a Nagy példát adhatok... 3 vsz., a Ki-ki terhét vállán..., a Bírja bár akárki... és a Szerelemtül csak kár... pedig 4 vsz. terjedelmü.

${ }^{318}$ BÓTA, i. m., 11.

${ }^{319}$ Uo., 21. Ld. az első fejezet (Ne gondold, szerelmem...) 64. lábjegyzetében.
} 
Ha jó szivvel nem vennék,

Söt, ha sas lehetnék,

$S$ móddal indulhatnék,

Mindjárt hozzád repülnék.

A strófa tárgyi argumentációja olyan közhelyes összehasonlításokon alapszik, melyek elemeit általában Balassi és Rimay verseiben is meg lehet találni. ${ }^{320}$ Ugyanezeknél a szerzőknél szintén megjelenik - ráadásul igen emlékezetes helyeken - a sas motívuma is. A Nagyciklus első versében (Jelentem versben mesémet...) Balassi egy idilli párkapcsolatot feldúló harmadik szereplőt ábrázol keselyü-metaforával, márpedig ez a madárfaj az ornitológia 17. századi áláspontja szerint ugyancsak a sasok neméhez tartozik. ${ }^{321}$ A Harmincadik c. versben (Mire most, barátom ...) pedig kedves példatárából választ egy exemplumot - a sast nevelö lányét - a még az oktalan állatoktól sem idegen önfeláldozó szeretet bemutatására. (Igaz, mint ahogy arra már Eckhardt Sándor is rámutatott, eredetileg Fulgosiusnál mindez fordítva történik, vagyis ott a lány neveli a saskeselyüt. ${ }^{322}$ ) Rimay verses életművében ez az elem nem fordul elő, de a tervezett Balassi-kiadás előszava annál költőibben méri a mester elsőségét a mindig az apróbb madarak elött szálló saséhoz. A fenti versszak azonban ezekre a szöveghelyekre nem látszik referálni. A párhuzam abban mindösszesen a gyors hazatérés szándékát fejezi ki, lévén a saskeselyü a korabeli közhiedelem szerint nemcsak nagyobb és bátrabb a többi madárnál, de gyorsabb is. ${ }^{323}$

A második versszak még mindig a bevezetéshez tartozik, mintegy az első strófa reflexivitását fokozva készíti elő a tulajdonképpeni mondanivalóját (transgressio).

2. Vettem leveledet,

Abban szerelmedet,

Kit nekem ajánl kedved,

Adod is értenem,

Töled eljöttelem

Mint újult meg keserved,

Kérsz, hogy hozzád térjek,

De mig az lesz, kérlek,

Ez kis válaszomat vedd.

A beszélő a jelek szerint valamiért nagy hangsúlyt fektet a levél-fikció részletezésére. A vers fenti harmadának egészét ugyanis - ha úgy vesszük - némely, még a címzettel nem azonos olvasó számára is nagyjából-egészében redundáns információknak ez a képes beszédet

\footnotetext{
${ }^{320}$ Vö. Én édes szerelmem ..., 4-5 vsz. (BÖM, 65. sz); ill. Valjon s de mi haszon ..., 4. vsz. (RÖM, 17. sz.)

${ }^{321}$ MisKolCZI Gáspár, Egy jeles vad-kert, s. a. r. STIRLING János, Bp., Magvető, 1983 (Magyar Hírmondó), 191206.

${ }^{322}$ BÖM, 181.

${ }^{323}$ MISKOLCZI, i. m., 195.
} 
tökéletesen nélkülöző közlése teszi ki. Az egyetlen Balassi-strófában összefoglalt tényleges válasz pedig akárha a Magyar példabeszédek didaktikus frázisainak volna elöképe:

3. Gonosz szerencsének

Botlását embernek

Nem mindenkor tarthatjuk,

Ha földre esését

És tagja törését

Abban mi nem láthatjuk,

De hogy az nyavalyás,

Kit elhagy kedves társ,

Igen bizonyithatjuk.

A huszadik sor első szavát (botlását) a kritikai kiadás olvasatától eltérve közlöm, az alábbiak miatt. Madách a kérdéses kifejezést 'Bochiassat' alakban másolta le. A betüsort változtatás nélkül egyféleképp lehetne kiolvasni: 'bocsássad', ez viszont a fenti mondatkörnyezetben nemigen értelmezhető. Radvánszky valószínüleg ezért javította a romlott szövegrészt a hasonló hangzású, szintaktikailag megfelelő és jelentését tekintve is odaillőnek érzett 'bukását' névszóra. ${ }^{324}$ Ezt a megoldást később Bóta László és Varga Imre is jóváhagyta. ${ }^{325}$ Csakhogy a bukás kifejezés jelentése szinonim az eséssel, noha az ének beszélöje éppen az utóbbinak szükségszerűségét szándékszik tagadni.

De nem csak szemantikai megfontolásból gondolom úgy, hogy Madách forrásában eredetileg 'botlását' állhatott. A tárgyalt strófa egy variánsa ugyanis a Vásárhelyi-daloskönyv egy már idézett versében is megtalálható, méghozzá a Piros rózsa színü... kezdetüben, ebből pedig szövegszerü bizonyítékot nyerhetünk az ügyben: ${ }^{326}$

3. Gonosz szerencsének vélik azt mindenek, mikor ember megbotlik, Hasonlatosképpen azki hüségiben mástól megcsalatkozik, Avagy barátjától, szép szeretőjétől azki messze távozik.

Mint ahogy az már az előző fejezetben ismertettem, az ének kritikai jegyzetei megemlítik Bóta László egy korábbi megfigyelését, mely szerint abban az akrosztichon (POGRANIONIA) első része a Pogrányi családnevet adhatja ki. ${ }^{327}$ Az Orpheusz-motívum elterjedtségének vizsgálata során ott és akkor nem tartottam fontosnak megemlíteni azt a levéltári adatot, miszerint Rimay halála után a hátrahagyott kisebb tárgyak leltárát egy

\footnotetext{
${ }^{324}$ RIMAY János Munkái, 22. sz.

${ }^{325}$ BÓTA, i. m., 8.; RMKT XVII/12, 53. sz.

${ }^{326}$ RMKT XVII/3, 194. sz.

${ }^{327}$ Stoll Béla közlése hivatkozott vers kritikai jegyzeteiben; ld. RMKT XVII/3, 642.
} 
bizonyos Pogrányi hitelesítette - nyilván István vagy János. ${ }^{328}$ Velük ugyanis a költő még életében több levelet is váltott, melyekben a szorosabb diplomáciai tartalom mellett szinte mindig akad egy-egy utalás valami Rimaynak küldött csemegére: tokhúsra, szarvasgombára, limóniára, stb. ${ }^{329}$ A kiadás jegyzetapparátusban Stoll leszögezi, hogy pusztán a versfök alapján lehetetlen eldönteni, vajon a név a szerzőre vagy a címzettre utal-e. (Istvánnak és Jánosnak két nőtestvére is volt, Anna és Zsófia. ${ }^{330}$ ) Azzal együtt a két variáns Rimay János személyében megragadható közelsége okán indokoltnak érzem a poémák rövid összevetését jóllehet, direkt kapcsolatot a kettő között nem feltételezek.

A Vásárhelyi daloskönyvben hagyományozódó ének 11 strófából áll (a teljes szöveg közlésétől ezért - terjedelmi okokból - eltekintek), vagyis majdnem háromszor hosszabb, mint a tárgyalt versike. Abban a pusztán formai jegyek is, mint az értelmezhetetlen betüsorral végződő akrosztichon és az itt-ott hibádzó rímelés arra utalnak, hogy a versszöveg romlott. Ezt szem előtt tartva a következőket érdemes arról elmondani. A Piros rózsa színü... kezdetü énekben az elhagyott szerelmes zaklatott kedélyállapotát az egymást érő, változatos retorikai eljárások (vád, panasz, eskü, könyörgés, stb.) meggyőzően juttatják kifejezésre. Szerkezete kiépítettebb, mint a tárgyalt versé. Ezt többek között a példák és hasonlatok alakzatán keresztül felhasznált narratív toposzok heterogenitása okozza: esik szó azok közt egyebek mellett közelebbről meg nem határozott istenasszonyokról (1. sor), Eurialusról és Lucretiáról (19-21. sor) és - láttuk - Orpheuszról (22. sor) is. A formulaszerü klisék közül feltétlenül említésre méltó a záróstrófa fohászkodása („Adja az Úristen, lássam egészségben hazajöveteledet”; 31. sor), mert az beleillik abba a sorba, melyet Bóta a kor szerelmi tárgyú levélverseinek - ahogy találóan nevezi - rekvizitumaiból állít össze. ${ }^{331}$ Ami elsősorban azért érdekes, mert a költemény utolsó sorának tanúsága szerint éppen nem mint olvasásra szánt textust definiálja magát. (Vö. „Én azért mind holtig, kedvedért mind fottig éneklem ez

\footnotetext{
328 „Az én bizott s mindenkor jó akaró uram, barátom halála után Baranyay Gáspár és Sárközy uraimék aprólékjait inventálva feljegyzették s egy posztóból varrott alkotmányban tették, Pográny uram ö nagysága pöcsétivel eröséttetett a kötés négy helen, a jegyzést is bele tették." (Ismeretlen levele Rimay haláláról és hagyatékáról.) RIMAY János Államiratai és levelezése, szerk. IPOLYI Arnold, Bp., 1887, 357.

${ }^{329}$ IPOLYI, 199-200, 202, 289-290, 290-291, 345-346. Azok közül halvány irodalmi utalás csak az utolsó, 1630. jan. 20-ára keltezett levélben olvasható Pogrányi István tollából: „Nagy örömmel értettem, hogy az Kegyelmed epistolájával érkezett hozzám az Kegyelmed tabellariusa, azmelyet szívem megbuzdulásával és szemeim szivárkoztatásával elolvastam egynehányszor. Valóságos igen igaz és helyes, uram, az Kegyelmed irása, hogy akárki is tanúlhat ez három esztendöknek elforgásában szegény keseredett magamon hagyatott fejemen, mint kelljen az embereknek ez világbeli állhatatlansággal osztogatandó gyönyörüségéhez ragaszkodni, igen igaz vers az is: Mundus iniustis mater, iustis sed noverca." Ld. ott. Eckhardt megengedi, hogy a fenti sorok az Udvar $s$ irigy tisztek ... kezdetü Rimay-versre vonatkozzanak, vö. RÖM, 212.

${ }^{330}$ Vö. NAGY Iván, Magyarország családai czimerekkel és nemzékrendi táblákkal, IX, Bp., Ráth Mór, 1862, 385. ${ }^{331}$ BÓTA, i. m., 24. lábjegyzet. A kérdést az Oly nehéz nem látnom... kezdetü vers kapcsán is említem, ld. a vonatkozó fejezetet.
} 
éneket”; 33. sor) További kontrasztszerü eltérés, hogy a Piros rózsa színü... kezdetü ének beszélöje a causa passzív (feminin) szereplöje. (Vö. „Mert azkit szerettem, feljebb, hogy sem mint mást, elhagyott, jól látjátok”; 3. sor.) Diszpozíciója kevéssé logikus. Ez abból adódik, hogy az egyes strófák v. strófatömbök abban (ahogy a közköltészeti alkotásokban rendesen) panelek módjára tevődnek össze - mindezt az is jól mutatja, hogy a vándorstrófa a Pogrányi nevére szerzett énekben mindenekelött azért lehetett a harmadik, mert az akrosztichon ehelyütt követeli meg a $g$ versföt -, együttesük a versszöveg jelentésének egészét tekintve emiatt gyakran inkoherens marad. A költeményben a szentencia jelesül még az elhagyatottság szituációját is relativizálja. Amiért viszont az mégsem okoz feltétlenül önellentmondást, az egyedül a tágabb érvényü (ebben az értelemben: triviálisabb) megfogalmazásból fakad illetve vélhetően abból az alkotástechnikai koncepcióból, miszerint a szakasz applikálója nem tartotta szükségesnek kifejezetten a saját helyzetére szabni ezt a szentenciát.

Mindezek tükrében az Ércnél, kösziklánál... kezdetű vers esetében a Bóta kitapintotta minőségeket (tömörség, meghittség, bensőségesség) a következőképpen lehet értékelni. A költemény tömörségét az ügy tárgyalásának egyszerüsége (simplicitas), az elbeszélés rövidsége (brevitas) és a nyelvi figurativitás visszafogottsága eredményezi; s ez a retorikai stratégia akkor sem tekinthető elhibázottnak, hogyha az ilyesfajta lényegre törés a metaforizáltságot éppenséggel felülírja. Ámde egy közhely applikációja mint válasz nem annyira meghitt, ahogy a lírai alapszituáción kívül eső személyes vonatkozások következetes nélkülözése sem igen sugall bensőségességet. A vers leginkább ti. a tartalmi semlegessége okán tekinthető mintaértékünek, ebből adódóan bárki által tetszőlegesen újrahasznosítható egy adott - a szövegben elég nyomatékosan meghatározott - élethelyzetben.

\section{Összefoglalás}

Az én szüvem gyönyörködtető szerelmesem ékes személyének kedves irására való választétel(em) c. költemény a tematikus versgyüjteményen belül is részegységet képező három verses válaszlevél első darabja. Bár formai szempontból szinte teljesen megegyezik a füzet előző énekével, attól mégis megkülönbözteti a strófaszerkezet kilenc soros tagolása. Az alaki jegyek tehát általánosan Rimay János költői mühelyének irányába mutatnak, a szerzőség kérdésében mégsem mondhatunk semmi bizonyosat; legfeljebb abbéli feltételezésünknek adhatunk hangot, hogy az Hárfa ...at valahova juthat... kezdetü vers és a szerelmes válaszlevelek alkotója nem ugyanaz a személy. 
A levél retorikai kidolgozottsága igen sablonos, s ettől iskolás darab benyomását kelti. Mindamellett tulajdonképpeni válasz rendeltetését abban egy olyan közhely tölti be, melynek egy variánsa a Vásárhelyi daloskönyv Piros rózsa színü... kezdetü énekében is megjelenik. Utóbbi az akrosztichonja révén legalábbis a Rimayval jó kapcsolatot ápoló Pogrányicsaládhoz köthető. Ezért azt kell feltételeznünk, hogy Rimay János környezetében olykor nemcsak kulináris, de irodalmi alapanyagok is gazdát cserélhettek időnként. 


\section{Szerelmesitöl vált valóban nagy kínt lát...}

Az ének a füzet anyagán belül szorosabb egységet képező verses szerelmi válaszlevelek közül a második (középső) darab, terjedelme ennek megfelelően mindössze három Balassi-strófát tesz ki. ${ }^{332}$ A további kettőtől (Az én szivem gyönyörködtető szerelmesem ékes személyének kedves irására való választételem és Szerelmese jobb kezének irását köszönti) eltérően szerzőiként számba vehető paratextusa nincs ill. nem maradt fenn, a címadás a tárgyalt versanyag általános tagolási gyakorlatának megfelelően a csak minimálisan informatív Más feliratra szorítkozik.

A szövegéböl kirajzolódó lírai alaphelyzet megegyezik a vele azonos tipológiai és metrikai szerkezetű a fizikailag közvetlenül előtte ill. utána álló költemények sajátjaival. Diszpozícióját tekintve viszont némiképp eltér e kettőtől. A demonstratív felütés ugyanis ezúttal nem az egyéni alaphelyzetet fejti ki. A Szerelmesitöl vált valóban nagy kínt lát... kezdetü ének felépítése az előbbiekben tárgyalt énekhez mérten is fordított. Abban - mint arról már esett szó ${ }^{333}$ - az argumentatív zárlat egy szentenciózus megállapítás applikációjában merült ki. Itt a nyitó strófában ismerhetni egy korábbi locus parafrázisára - tehát elődszövegét a vers beszélője az által formálja érzelmi közhellyé, hogy egy határozószóval (,valóban”) is nyomatékosítva evidenciaként hirdeti annak igazát:

1. Szerelmesitöl vált

Valóban nagy kint lát,

Nincs vége keservének,

Bútúl bágyad, eped,

Álmot is nem enged

Vehetni két szemének,

Ha megenyhiti is,

Nincs ép kedve mégis,

Nem kell ir bús lelkének.

Vagyis az érvmenet nem csak az Ércnél, kősziklánál... kezdetűhöz képest fordul a visszájára. Az első sor mint allúzió, ahogyan azt már a Rimay János müveit sajtó alá rendező Eckhardt Sándor is regisztrálja a kritikai kiadás jegyzeteiben, a hatodik Célia-versre (Azmely keresztyén hü...) utal, ${ }^{334}$ méghozzá - Nagy Ferenc kiegészítése értelmében - úgy, hogy annak

\footnotetext{
${ }^{332}$ Kritikai kiadása: RMKT XVII/12, 54. sz.

${ }^{333} \mathrm{Ld}$. az előző részfejezetet.

${ }^{334}$ Vö. RÖM, 263.
} 
konklúziójától kezdve építkezik újra a mintaszöveg kiindulópontja felé; a két alkotás elrendezése ugyanakkor a tartalmi elemek inverz felépítése ellenére is megegyezik, hiszen azokra egyformán igaz, hogy „,az 1. strófa a causa meghatározását, a 2. a beszélő arcképét, a 3. pedig a felettes hatalomhoz fordulást tartalmazza. "335

Ennek szemléltetéséhez persze indokoltnak látszik az említett Balassi-vers maradéktalan idézése:

1. Azmely keresztyén hü, s kiben nincs hamis szü, lelkét ördögtöl félti, Nem csuda, én is hát hogy féltem Céliát, midön gonosz késérti, Mert csak ö az lelkem, csak ö jóm énnékem, éltemet ö segéti.

2. Óh, siralmas szállás, kit keserves válás szegény fejemnek rendelt! Immár hova légyek, s ölemben kit végyek, ha szántalan bú terhelt? Óh, szerencsétlen nap, ki elragad és kap attól, ki hiven kedvelt!

3. Szerelmesétôl vált, nem csuda, az halált hogyha fejére kéri, Mert bújában halál orvosságot talál, fájdalma végét éri, De az szörnyü válás végtelen kínvallás, szivét örökké sérti.

Nagy Ferenc úgy találja, hogy a Célia-vers harmadik versszakában alkalmazott túlzás az emelkedett (gravis) stílus konzekvens fenntartásából adódik. ${ }^{336} \mathrm{Az}$ ismeretlen szerző a litterális értelemben blaszfémiát súroló - mert a végtelen jelzőt és az örökké határozót az evilági lét eseményeihez rendelő - képhasználat változatlan megőrzésére nem törekszik. Azt ugyanakkor mégsem számolja fel teljesen, de a terminológia radikalitását jelentősen mérsékli: a beszélő immáron nem meghalni, csupán - akárcsak a gyüjtemény hatodik énekében - aludni vágyik. ${ }^{337}$

Meg kell jegyeznem, hogy a második sor állítmányhalmozása (,,Bútúl bágyad, eped, álmot is nem enged vehetni két szemének”) mint a kor költészetében ritkaságszámba menő stilisztikai bravúr a gyüjtemény hetedik, tizedik és tizenötödik énekéből is kimutatható. ${ }^{338}$ De ha az első strófa egészét tekintjük, akkor az is kitűnik, hogy abból egyes szavak Rimay $E z$

\footnotetext{
335 Vö. NAGY, i. m., 25-26.

336 „Az utolsó strófa hiperbolikus közhelye (halált fejére kéri) megfelel úgy a végletes értékminősitésnek, mint azt absztrakt logikának. A fájdalom és emelkedettség ilyen magasságából nemcsak lehet, de kell is szóba elegyedni akár a halállal, akár az égi hatalommal, hiszen elmozdulni felfelé már nem lehet, lefelé pedig csak a szubtilitás, az anyagtalanság ellentétes végletéig." NAGY, i. m., 27. A túlzás alakzatának kerülése nem csak ezt a verset jellemzi; ld. a Semmi állat nincsen... kezdetü ének tárgyalásában.

337 Vö. a Semmi állat nincsen... kezdetü ének 4. sorával: „Éjszaka is szeme semmi álmot nem kap.” Ld. a vonatkozó fejezetet.

338 „Mint ez nött, nyílt, nyugodt szép harmatos bokron” (Egy szép rózsaszálat küldtem ajándékon..., 4. sor); „Fenye természetet, meg... szivet ront, változtat, szelígyit” (Hárfa ...at, valahova juthat..., 2. sor); ,.Vidulj meg, derülj fel, ne hervaszd orcáját...” (Beborult, felhözött, bánat hozó egem, 8. sor). Vö. BÓTA, 14., 26. lábjegyzet. A kérdést a Semmi állat nincsen... kezdetü ének kapcsán is érintem, ld. a vonatkozó fejezetet.
} 
világ mint egy kert... kezdetü versében is előfordulnak, méghozzá hasonló (rím)pozícióban. Vö. 13-15. sorok: ${ }^{339}$

Ki-kit bánat sebhit,

Bút öröm nem enyhit,

Vége nincs keservének...

A második strófa tehát mindkét vers esetében a külvilágnak alkotott önarckép (quid affectet quisque) megképzését szolgálja, s ahogy arra Nagy Ferenc is figyelmeztet, az nemcsak Balassinál, de az ismeretlen szerző művében is a megszólítás alakzatain keresztül jön létre: ${ }^{340}$

2. Így vagyon én dolgom,

Mert csak búslakodom,

Nem látván szerelmemet,

$S$ noha eltávoztam,

De velem elhoztam

Szivemben zárt képedet,

Buzgó kívánsággal,

Nyughatatlansággal

Óhajt lelkem tégedet.

Jonathan Culler az e tárgykörben publikált nagy hatású tanulmányában egyebek mellett éppen azt fejtegeti, hogy az aposztrophé mindig is kiválóan alkalmas volt az énkép konstituálására. $^{341}$ Culler interpretációja szerint ez a figura különösen a válaszadás képességével nem rendelkező megszólítottak esetében látszik önmagán túlmutatni, hiszen ekkor alkalmazásának célja egyértelműen a költői szerepvállalás kinyilvánításában ragadható meg. ${ }^{342}$ Jobban meggondolva pontosan ez zajlik le az Azmely keresztyén hü... második strófájában is. Annak három sora egy-egy modalitását tekintve tükörszimmetrikusan elrendezett versmondatból tevődik össze: a két aposztrofikus exclamatio közé egy nem mellékesen stílustörést is eredményező patetikus kérdés ékelődik be, melyre mintha legalábbis csak az invokált entitások (szállás ${ }^{343}$ és nap) adhatnának feleletet. Az ismeretlen szerző versének beszélője azonban kedvese személyében egy olyan címzettet szólít meg, aki elvileg

\footnotetext{
${ }^{339}$ RÖM, 30.

${ }^{340}$ NAGY, i. m., 27.

${ }^{341}$ Vö. „,[A]z aposztrophé vocativusa olyan eszköz, amelyet arra használ a költöi hang, hogy egy tárggyal olyan viszonyt alakitson ki, amely segít megképeznie saját magát." Jonathan CULLER, Aposztrophé, ford. SzÉLES Csongor, Helikon, 2000, 376.

${ }^{342}$ Vö. „Aki eredményesen invokálja a természetet az, akihez aztán a természet is beszélhet. [...] Ez a költöi igény tiszta megtestesülése: a szubjektum azon igényének megtestesülése, hogy költeményében ö ne csupán az empirikus költő, a versíró, hanem a költői hagyomány és a költészet [poesy] szellemének megtestesülése legyen. Meglehet, az aposztrophé mindig a múzsa közvetett invokációja.” Uo., 377-378..

A A szállás névszónak Eckhardt a kritikai kiadás jegyzetapparátusában a Nyelvtörténeti szótár vonatkozó szócikke alapján successio ('rákövetkező dolog, változás') értelemben magyarázza. Vö. BÖM, 263.
} 
a fikcióból kilépve is képes lehet válaszolni neki, márpedig e módosítás újfent csak az örökbe kapott költői nyelv konszolidációjának szándékára enged következtetni.

Lényegében új közléselemet a második strófa az elsőhöz képest (mint ahogy az egyébként az előző fejezetben tárgyalt Ércnél, kősziklánál... kezdetű ének esetében is megfigyelhető volt) alig tartalmaz, vagyis - ahogy Nagy Ferenc értelmezi - a versszöveg magát a hasonlósági relációt (,,igy vagyon én dolgom”) hangsúlyozza ki anélkül, hogy a Célia-vers címében (Hatodik, kiben az szeretőjétől való elváltán kesereg, féltvén, és itt az lelkéhez is hasonlitja) elöre jelzett, struktúrájában mindenekelött Balassi költészetére jellemzőnek tartott hasonlatot átvenné. ${ }^{344}$ (Tegyük hozzá mintegy rekapitulálva, ez azért is lehetséges, mert a már bebizonyított konklúzió irányából közelít.) Záró strófaként végül egy, a vizsgált füzet versanyagában több helyen is alkalmazott fordulatot tesz meg, mégpedig úgy tehát, hogy annak egy-egy eleméből könnyen asszociálhatunk az Azmely keresztény hü... első strófájának néhány hívószavára: ${ }^{345}$

3. Adja az Jóisten,

Szerencsém lehessen,

Egészségbe' lássalak,

$S$ te hü szerelmedben,

Kit irsz leveledben,

Hamar találhassalak,

Te veled beszélvén,

És neked örülvén

Százszor csókolhassalak!

Bár korábban már érintettem ezt a vonatkozást is, ${ }^{346}$ most mégis szükségét érzem visszatérni hozzá: e viszontlátásért és kézfogásért, sőt (mint amellett Jankovits László érvel meggyőzően ${ }^{347}$ ) talán egyenesen kézfogóért fohászkodó záradék 17. sz. eleji közkeletüségét tehát Bóta László ismeri fel, s azt e versen kívül még további, a korpuszhoz - úgy lehet közel eső szövegforrásból, a Balassa-kódexből adatolja. ${ }^{348}$

Az egyik változat Rimay János Ne csudáld szívemet... kezdetű énekének utolsó előtti szakasza:

5. Te, kegyelmes Isten, mindkettünk szerelmét Neveljed, s tartsad meg testünk egészségét,

\footnotetext{
${ }^{344}$ Balassi Bálint hasonlatainak korabeli újszerüségéről ld.: ECKHARDT Sándor, A régi magyar költők képei, 318 321. A Célia-vers hasonlatának kiváló értelmezését adja Nagy Ferenc idézett szakdolgozatában. Vö. NAGY, i. m., $28-31$.

${ }^{345}$ Ezek: Jóisten - keresztyén; hü szerelem - gonosz kisértés; hamar - örökké. Vö. Uo., 26.

${ }^{346} \mathrm{Az}$ Oly nehéz nem látnom... kezdetű énekről írott fejezetben. Ld. ott.

${ }^{347}$ JANKOVITS László, Soliloquium és oratio Rimay egy versében, 217-218.

${ }^{348}$ BÓTA, i. m., 11.
} 
Foghassuk örömmel hamar egymás kezét.

A másik az ún. mostani poéták szerzeményeit tartalmazó egység Csudálatos nagy bánatja szívemnek... kezdetü darabjának záró strófája: ${ }^{349}$

7. Istennek ajánllak már ö hív kezében (s kedvében),

Tartson meg mindvégig hiv szerelmedben (kedvedben),

Bút ne ontson soha te örömödben,

Szerelmed neveljen hozzám hivségben

Adja is személyed látnom jó egészségben,

Rövid nap kezedet fogván kezemben.

Fentiek közül Bóta a tárgyalt vers utolsó versszakáról úgy nyilatkozik, mint amelyik „költőiebben”, mert „gazdagabb érzelmi motiválással” dolgozza fel egyazon gondolatot értsd alatta: még a (hiteles) Rimay-poémánál is sikerültebb. ${ }^{350}$

Nos, e szubtilis esztétikai ítéletet a három költemény részletező elemzése nélkül nem bírálhatom felül; miután viszont ez a bővítmény nem füződhet szervesen a dolgozatom vezérfonalához, ehelyütt attól eltekintek. Anélkül is jól kivehető ti. az a tényállás, hogy mindhárom idézett vers szerzője a saját invenciójának megfelelően alakította át a vándorló panelt - a levélfikció pl. csak a Szerelmesitől vált valóban nagy kínt lát... kezdetü ének variánsába szövődött bele. ${ }^{351}$

Mindez azért is érdekes, mert a korabeli udvarló költészetben egy másik megoldás is kínálkozott az elödszövegek reciklálására, amely az imént bemutatott applikációs gyakorlatot tkp. megspórolta magának. Eklatáns példája ennek az a Batthyány Ferenc jegyezte verses egyveleg, melynek tárgyunk szempontjából különös relevanciát kölcsönöz, hogy részben szintén a hatodik Célia-vers után készültt: ${ }^{352}$

1. Azért nekem immár el kell mast indulnom,

De elmémet nálad ugyan itt kell hadnom,

Rólad gondolkodnom,

Legyen Isten hozzád, édes vigasztalóm.

2. Nem úgy megyek el, hogy lennék nálad nélköl,

Mert minthogy az test nem élhet lélek nélköl,

Így te szerelmedtöl

Nem válhatom én meg már halálom nélköl.

\footnotetext{
${ }^{349}$ RMKT XVII/3, 26. sz.

${ }^{350}$ BÓTA, $i . m ., 11$.

${ }^{351}$ Vö. NAGY, i. m., 25-26. Ugyanitt Nagy Ferenc kiemeli, hogy a Balassi kései költészetéhez sorolt énekek egyike sem levélvers.

${ }^{352}$ ECKHARDT Sándor, A körmendi Balassa-emlékek, EPhK 1943, 45.
} 
3. Óh, siralmas szállás kit keserves válás szegin fejemnek rendelt! Immár hova legyek, elömbe mit vegyek haszontalan bút, terhet? Óh, szerencsétlen nap, ki elragad és kap attól, ki hiven kedvelt!

4. Szerelmesétöl vált nem csoda, az halált hogyha fejére kéri, Mert bújában halál orvosságot talál, fájdalma végét éri,

De az szörnyü válás végtelen kínvallás, szivét örökké sérti.

5. Mast is örömömet magaddal elvetted kedvemmel egyetembe', Reád gyúlt szerelmem titkon éget engem keseredett elmémbe, Áldott szemeidet, gyönge szép szinödet juttatván én eszembe.

6. Öszvekötött kézzel, hajlott fövel, térddel önekie könyörgék, Kinek jó voltátúl, mint istenasszonytúl kegyelmet reménlenék, Hogy megkegyelmezzen, tovább ne gyötörjön, áment reá kiálték.

A kontaminált ének első harmada a Balassi házassága előtt szerzett énekei között számon tartott Negyedik címünek (Bizonnyal esmérem rajtam most erejét...), a középső a Célia-ciklus hatodik darabjának (Azmely keresztyén hü...), az utolsó pedig a Júliához írt énekek közül a Negyvenedik címünek (Engemet régolta sokféle kénokba...) két-két strófájából tevődik össze. ${ }^{353}$ A Balassa-kódexben hagyományozódott szövegváltozatoktól, láthattuk, ez érdemben három ponton tért el: egyszer a tizedik, két ízben pedig a tizennyolcadik sorában.

Idézett tanulmányában Eckhardt az előbbi kapcsán úgy vélekszik, hogy a Célia-vers kódexből ismert variánsa „,nem épp a legkifogástalanabb értelmet adja”, ezért hajlik rá, hogy az attól máskülönben is majd' félszáz évvel korábban keletkezett Batthyány-levélben olvasható variánst tekintse a szerzői akarathoz közelebb állónak. ${ }^{354}$ A Negyvenedik c. vers zárlatának változatáról csak annyit közöl, hogy Batthyány Ferenc a Júlia név kezdőbetüjének átvezetése után módosította azt igen körültekintően a fent látott visszaható névmásra. Eckhardt ezáltal nemcsak az általa apróbbnak nevezett, a szöveg értelmét nem befolyásoló morfológiai ill. szintaktikai változtatásokat hagyja figyelmen kívül tehát, de egy füst alatt a szakrálisabb (összekulcsolt kéz) és a militánsabb (összekötözött kéz) töltésü frazémák közötti különbséget is jelentéktelennek nyilvánítja.

Annyiban feltétlenül igazat kell adnunk Eckhardtnak, hogy e szöveghely esetében nem kínálkozik semmiféle támpont a fentebb látott realizációkat eredményező folyamat leírására. Csakhogy effélét voltaképpen az előző esetben sem érzékelhetünk. Mint ahogy a fejezet elején már utaltam arra, az Azmely keresztyén hü... kezdetü ének fennköltséget sugárzó aposztrophikus fordulatok közrefogta ötödik sora - mely a költemény szerkezetét tekintve nemcsak a strófa, de az egész vers középpontja is - egyszerre profán, hovatovább szexuális

\footnotetext{
${ }^{353}$ Vö. BÖM, 5. sz., 16-17. vsz.; BÖM, 83. sz., 2-3. vsz.; BÖM, 48. sz., 4., 13. vsz.

${ }^{354}$ ECKHARDT, A körmendi Balassa-emlékek, 46.
} 
vonatkozást kap. De hogy a Batthyány-levél diszkrétebb variánsa a szerző korábbi intencióját tükrözi-e vagy Batthyány Ferenc szándékos v. szándéktalan kreativitásának gyümölcse, esetleg ugyanezt a készséget fordított előjellel a Célia-versek későbbi másolójáról kellene feltételeznünk - e kérdést valójában nem áll módunkban eldönteni.

Nem kísérli meg azt egyébként az énekegyveleg keletkezéstörténetének rekonstrukciójára vállalkozó Vadai István sem, aki szerint a hat versszak ilyetén újrarendezése egy, a cento müfaji szabályainak megfelelő kompozíciós metodikaként értékelhető. ${ }^{355}$ Ennek kieszközlőjét Vadai előbb Batthyány Ferenc, később Balassi Bálint személyében valószínüsíti. ${ }^{356}$ Én azonban óvakodnék ennek az eljárásnak különösebb mügondot tulajdonítani. Nem tudok eltekinteni ugyanis attól a ténytől, hogy a Nagyciklus Negyedik c. verse a szóban forgó szakaszokat megelőzően (éppen az akrosztichon copyright értékü részét kitevö ${ }^{357}$ ) tizenöt Palkó-strófában részletezi annak okát, hogy miért kell szerelmesétől elválnia - s hogy azok közül legalábbis egy mégiscsak elengedhetetlen volna ahhoz, hogy a strófakezdő utalószó (azért) valamiféle értelmet kapjon a töredékben. ${ }^{358}$

A körmendi levelek alapján tehát csak hozzávetőlegesen körvonalazható, hogy a Balassiversanyagnak miféle kollekcióját kapta kézhez Batthyány Ferenc. ${ }^{359}$ Azt sem lehet pontosan tudni, hogy miben másította meg a rendelkezésére bocsátott költemények tartalmát. Teljes bizonyossággal csupán azt mutathatjuk ki, hogy mit idézett abból változatlan alakban. A tárgyalt vers elemzése szempontjából viszont ez is sokatmondó lehet. A kontaminált énekben felhasznált Balassi-citátumok között nagyobb általánosságban ti. szembe ötlik abbéli összefüggésük, hogy az első kettőben megjelenik a halálvárás motívuma, a harmadik, befejező részlet pedig szintén egy, a szerelmi halál (persze: közhelyes) gondolatával

\footnotetext{
355 „A búcsúzó szerelmes helyzetéhez illő szakaszok önálló, új költeménnyé álnak össze.” VADAI István, Balassi Bálint Fajtalan éneki, ItK, 1994, 680.

356 VADAI István, Batthyány Ferenc és Balassi Bálint = A Batthyányak évszázadai, szerk. NAGY Zoltán, Körmend-Szombathely, 2006, 218.

${ }^{357} \mathrm{Az}$ akrosztichon teljes terjedelmében a BALASSIBALJNTHÉANNA betűsort adja ki. Ennek integritását legutóbb Pap Balázs vizsgálta. Vö. PAP Balázs, Az akrosztichonok és az elsö harminchárom, 49.

${ }^{358}$ Idézett dolgozatában Vadai a helyzetet azzal magyarázza, hogy a tapasztaltabb költő maga dolgozott az udvarlás processzusában járatlan ifjú barátja keze alá, s ezért e jelenséget Cyrano-effektusnak nevezi. Mivel azonban a többféle kölcsönszövegböl összeállított végeredmény meglehetősen inkoherens, én magam kézenfekvőbbnek látom azt Bumblebee nevéhez kötni. Bumblebee (a magyar változatban: Űrdongó) a Transformers univerzumban egy olyan autobot, aki - miután tönkrement a hangprocesszora - a környezetével csak a rádióján keresztül tud kommunikálni, $\mathrm{s}$ ezért közlendőjét mindig az egyes rádióállomások müsorának részleteiből kénytelen összeválogatni. Vö. Alan Dean FosTER, Transformers: A múlt árnyai, ford. NovÁK Gábor, Debrecen, Gold Book, 2007, 163.

${ }^{359}$ Vö. ECKHARDT, A körmendi Balassi-emlékek, 46.
} 
kacérkodó forrásból került kiválasztásra - úgy, hogy ennek segítségével az egyveleg egy patetikus ámen-mondással végződjön. ${ }^{360}$

Eckhardt megállapításai közé tartozik az is, hogy Batthyány Ferenc hajlamosnak látszik eufemizálni egyes Balassi-reminiszcenciákat. ${ }^{361}$ Csakhogy ebbéli igény a hatodik Célia-versböl átemelt passzusban legfeljebb a szexuális allúzió (ölemben kit végyek) leépítése mögött feltételezhető. Azt a pragmatikai természetű ill. transzmutatív-hiperbolikus figurációt viszont, melynek szövedékét - ld. fent - a Szerelmesitől vált ... ismeretlen szerzője merőben praktikus okokból lazította fel, az összeállító (bárki is legyen az) ezúttal nagyrészt érintetlenül hagyja. Ami csak annyiból érdemel szót, mert egy misszilis tartalmát képezvén ez az egyetlen olyan variáns, amit minden kétséget kizáróan próbára tettek a gyakorlatban is - noha az Azmely keresztyén hü... kezdetü Balassi-vers kicsengése egy a viszontlátás örömével nem számoló, reményvesztett szerelmes profiljához vezet, s mint ilyen, az e tekintetben változatlan újabb kidolgozásban is csak mérsékelten tủnik alkalmasnak a direkt udvarlásra.

Végezetül meg kell említenem a hatodik Célia-vers egy időben és térben egyaránt távoli visszhangját is. Az alábbi, már incipitjében is Balassit idéző ének a Vásárhelyi daloskönyvből került elő: ${ }^{362}$

1. Mint párduc prédára, kegyesem ily búmra szüntelen igyekezik, Kinom hogy láthassa, örülhessen rajta, csak azon gondolkodik, Nem gondol fejemre, készül gyötrelmemre, kénommal ugyan hízik.

2. Az fenevadaknál, tigris, oroszlánnál kegyetlenb természeti, Mert még az is szánja fiát, mikor látja veszedelemben lenni, De szerelmem nékem az én sok gyötrelmem vidám orcával nézi.

3. Reméntelen sorsom reám hogy bút forrjon, reménleni sem tudtam, Hogy attól véletlen ugyan történetlen kelletik eltávoznom, Ki volt személyével, fris tekéntetével szabadságomtól fosztóm.

4. Gyönyörü nyelvednek kedves szép zengési mikor gyönyörködtetnek, Akkor én szivem is bútól vetkezik le és örömre indul fel, Talám mindörökké tündöklö napjaim érted homályban jö fel.

5. Igyefogyott fejem, gyászviselö lelkem, hát mint reménlhetsz immár?

\footnotetext{
${ }^{360}$ Vö. Engemet régolta sokféle kínokba... (BÖM, 48. sz.) 5-6. vsz.

361 Eckhardt a követett számozás szerinti VII. levélben mutatja ki az alábbi Balassi-reminiszcenciát: „Egyetlenegy szépségem, mindéltig kínzasz-e, az te hív szolgádat elveszni nem szánod-e? ” Vö. „Egyetlenegy szépségem, mindéltig így kínzasz-e? / Az te hív szolgádat [...] megölni nem szánod-e?” (Keserítette sok bú..., BÖM, 9. sz., 7. sor.) Batthyányi fogalmazásában a következő okokból lát szépítő szándékot: „, $A$ »megölni« szót a szelíd Évácskával [é. a címzett Lobkowitz Poppel Évával] szemben talán túl erősnek találta, hogy azt »elveszni«-vel helyettesitette.” ECKHARDT, A körmendi Balassi-emlékek, 38.

${ }^{362}$ Kritikai kiadása: RMKT XVII/3, 193. sz. Vö. IMRE Ilma, i. m., 45-51.
} 
Ha nem szánja kénom kegyetlen asszonyom, hálójával készen vár,

Teljék kedve benne, hogy éltem üldözze, felölem eltér immár.

6. Talám még, tudom, él s könyvben fordult szemmel keserves verseimet Kezdi tekénteni, magában így szólni: „Óh, Úristen, hogy szegént

Meg nem szántam akkor, mikor láttam sokszor értem szenvedni sok ként?"

7. Óh, szerencsétlen nap, mely már töled elkap, miért akkor homályban Hogy nem borultál volt, látnom miért hadtál volt elsőben ott búcsúban? Óh, mely keserves kár, hogy tölem távol jár szivem érted már gyászban.

8. Menny, föld, tenger múlók, kösziklák is romlók hosszú üdö jártára, Tudom, ily sok búmnak, kik érted hervasztnak, vége lészen valaha, Semmi sincs világon, ki örökké tartson s el nem múlnék sokára.

9. Ezeket sietve gyülés után versben egy ifjú ü szállásán Szerzé, szerelmének mikoron bánkódnék töle eltávozásán, Sir, kesereg érte szüböl fohászkodván, most útjára indulván.

Noha a versfők (MARGITOME) szavatolják az ének integritását, az idevágó hetedik strófában eluralkodó grammatikai következetlenségek a szöveg egészének romlott állapotáról is vallanak. Az első aposztrophikus szakasz egy impozáns soráthajlás révén kebelezi be az eredetileg modális kontrasztot jelentő kérdő alakzatot (ez a mozzanat már a Balassi-strófa versmondat-határainak feloldódásáról tanúskodik): a beszélő - ahogy a tárgyalt versben is láttuk - a valódi címzetthez fordul, de nem iktatja ki a felsőbb hatalom (végső soron: az idő) megszólítását sem, ennek folyományaként a mondottak vonatkozása az invokáció e két tárgya között csapong ide-oda.

Mindent összevetve az a körülmény pedig, hogy az idézett münek nincs egyetlen olyan sora sem, mely ne tartogatna egy-egy a nagy előd repertoárjából eredeztethető képet v. szófordulatot, pontosan egybevág azzal a régebbi költészettörténeti érdekü megfigyeléssel, miszerint a 17. század második felére az alkalmi versfaragók afféle szerelmi közhelyszótárként használták fel Balassi Bálint költői életművét. ${ }^{363}$

\section{Összefoglalás}

Balassi Célia-ciklusának hatodik darabja, az Azmely keresztyén hü... kezdetü ének inspiratív hatását alapvetően három fennmaradt verses emléken mérhetjük le. Ezek közül időrendben az első az a tematikailag nagyvonalúan illeszkedő egyveleg, melynek anyagát élete utolsó

\footnotetext{
${ }^{363}$ Vö. SzIGETI Csaba, Appendix Balassiana: Kronológia, tradició, hagyománytudat a XVII. századi Balassikövetö nemesi költészetben, ItK, 1985, 684.
} 
éveiben maga a költő válogathatta össze saját korábbi szerzeményeiből fiatal barátja, Batthyány Ferenc részére. Az ifjú nemes a kölcsönkapott strófákat egy udvarló levelébe szerkesztette bele - ezáltal a balassias galantéria mint nyelvi teljesítmény végre kivívta helyét ténylegesen udvari környezetben is. Ennek a változatnak tehát az a legfőbb sajátossága, hogy abban az egyes alkotóelemek a szerzői variánsoktól nemigen térnek el, vagyis az egész eljárás motivációja jobbára a feltétel nélküli ráhagyatkozásban merül ki.

Minden valószínüség szerint ezután keletkezhetett a Madách-Rimay-kódexek őrizte Szerelmesitől vált... kezdetü ének. Ez a Batthyány Ferenc autográfjából ismert összeállítással szemben nem illusztrációja egy udvarló levélnek, hanem önállóan tölti be annak funkcióját. A versike egyedül az említett Balassi-költeménnyel vet számot, olyan szöveghelyként (locus) tételezve azt, ahonnan érveket származtathat a maga céljaira - ám ennek érdekében csupán az Azmely kereszyén hü... konklúzióját veszi alapul, az argumentációját módszeresen felpuhítja. A nagyfokú tudatosság tükrében - valamint a tárgyalt vers közvetlen szövegkörnyezetét is figyelembe véve - a közlésanyag viszonylagos elnagyoltságáról megkockáztatható az a feltevés, hogy az is elsősorban a verses levelek alkotta mikrokorpusz mutatvány-jellegét igazolja. Vagyis az utódszövegek közül a vizsgált vers az egyetlen, amelynek szerzője a jelek szerint valóban kész volt megmérkőzni a költő Balassi Bálinttal.

Legtovább ugyanis bizonyosan az a Vásárhelyi daloskönyvben hagyományozódott közköltészeti változat alakulhatott, amely számos Balassi-allúzióján keresztül akárha a mester nyelvi erejét kívánná megidézni - csakhogy azt mindenféle poétikai koncepció és reflektáltság nélkül teszi, ezért mintáihoz való viszonya bizonyos értelemben éppoly kritikátlan, mint a Batthyány Ferenc által rögzített énekegyvelegé. 


\section{3. Én édes jobb kezem, töled kedven veszem...}

Az ének a füzetbéli válaszlevél-blokk harmadik és egyben utolsó darabja. ${ }^{364}$ Ahogy az első kettő, úgy ez is kilenc sorra osztott Balassi-strófákban íródott, és azokból szintén csak hármat számlál. Szerzőiként is valószínüsíthető címe ennek is van: Szerelmese jobb kezének irását köszönti. Mindamellett a gyüjtemény első olyan egészben fennmaradt tétele, melynek éléről elmarad a Más megjelölés. Nótajelzése nincsen.

A versszöveg alkotó ötletének kiteljesítésében a szinekdoché trópusa dominál: a beszélő nem közvetlenül a kedvesét aposztrofálja hízelegve, csupán annak jobb kézfejét igyekszik befolyásolni; vagyis azt a végtagot, amellyel a hölgy (a fikció értelmében) előzőleg szerelmes levelet írt neki - feltételezve, hogy ez a rész irányítja az értelmes egészet. A kissé keresett vezérmotívum tehát mintha a manipuláció etimologizálására épülő allegória megképzését szolgálná:

1. Én édes jobb kezem, Töled kedven veszem, Hogy nékem ajánlatod Asszonyodnak kedvit, S hozzám hü szerelmit Ujjaival iratod, Veszed nem kis hasznát, Ha vele két karját Nyakam környül rakatod.

Az egyes szófordulatok azonban nem teljesen ismeretlenek a régi magyar költői nyelvben Bóta legalábbis a versszak első felében regisztrálja az első, a Rimay-életmű egy helyével, jelesül a Szólítván nevemen ... kezdetü ének kilencedik strófájának utolsó soraival összecsengő szószerkezetet. ${ }^{365}$ Abban köztudottan Venus istenasszony kínálja fel a beszélőnek Lídia szerelmét: ${ }^{366}$

9. Igaz szeretettel, Tökéletességgel

Foglald te is magadhoz,

$S$ jó szolgálatodért Ad ö jó, hasznos bért, Csalárdsággal sem kínoz

\footnotetext{
${ }^{364}$ Kritikai kiadása: RMKT XVII/12, 55. sz.

${ }^{365}$ Vö. BÓTA, i. m., 14.

${ }^{366}$ E strófa értelmezéséhez ld.: BALÁZS-HAJdU, JANKOVITS, PAP, i. m., 29.
} 
Mert áldott szerelme

S hozzád való kedve

Hü leszen s rád bút sem hoz.

A párhuzamot Varga Imre is átveszi a kritikai kiadás jegyzetapparátusba. ${ }^{367}$ Természetesen a rímszóként alkalmazott (az elöbbiben tárgyasan, az utóbbiban tárgyatlanul ragozott) kedv és szerelem, valamint a hozzájuk kapcsolt hü jelző kevés ahhoz, hogy bizonyítsa a két citátum közti kapcsolat intencionáltságát, ugyanakkor Venus istenasszony szerepeltetése örvén jegyezném meg, hogy noha a vizsgált tizenöt szerelmes énekben tetten ért toposzok némelyike bizonyosan antik eredetre vezethető vissza, ámde direkt mitológiai vonatkozások azokban - föleg Balassi ill. Rimay lírájához mérten - csak szórványosan fordulnak elő. ${ }^{368} \mathrm{~A}$ tárgyalt versböl példának okáért, valamint a szerelmi válaszlevelek többi darabjából is teljes egészében hiányoznak. Ugyanezt állapíthatjuk meg azokról a középkori lovagi költészet szerelemfelfogásának visszhangját illetően is. Az idézett részben (Pirnát Antal idevágó meglátásaira hagyatkozva ${ }^{369}$ ) az asszony kifejezés inkább utalhat a hölgy előkelő társadalmi pozíciójára, mintsem a családi állapotára - de attól a füzet anyagában a cortezia terminológiájának ismerete is csak egy-egy alászállott klisé erejéig mutatkozik meg.

Ami pedig a strófa második felében körvonalazódó alkut illeti, abban Bóta a Nagyciklus Huszonharmadik c. (Keseritette sok bú és bánat az én szívemet...) áthallását érzékeli. ${ }^{370}$ Annak 9. versszaka ti. így szól:

Oly igen nagy ereje vagyon te két szép szemednek,

Akiket akarnak, megölnek, s ismét megélesztnek;

Az hónál fejérb kezed, kit Istentül kérek,

Hogy rövidnap szorosan ölelvén rám keröljenek.

A Balassi-versben a kedves a megszólított, és ugyanitt a szerelem viszonzásának e gesztusát kiváltandó a beszélő egy valóban felettes hatalom közbenjárásáért fohászkodik. A kettőben tehát jobbára a szerelmes ölelés mozzanata közös, ámde a szóhasználat csak kevéssé egyezik:

\footnotetext{
${ }^{367}$ Vö. RMKT XVII/12, 736.

${ }^{368}$ A tizenöt vers közül csak négyben találhatni hasonlót. Ezek: ,, Vakmerőn netalám az Cupido sem bánt” (Ki-ki terhét vállán... 12 sor); „,Jupiter is szépnek tilalmat adni félt”, (Szerelemtül csak kár..., 3. sor); ,,Orpheusz, ím látod, sokféle állatot magához mint szoktatott” (Hárfa ...at valahova juthat..., 3, sor); „,Venusnak tüzivel nem hagysz melegednem”, (Beborult, fölhözött..., 4. sor).

${ }^{369}$ A szó jelentéstörténeti fejlődését egy helyütt Pirnát Antal mutatja be Balassi költői nyelvének udvari(as)sága kapcsán. Mint írja, az asszony szavunk eredetileg királynö értelemben volt használatos, s noha a XVI-XVII. századra már leginkább a férjezett nő jelentéssel bír, tiszteletteljesebb jelentésárnyalatával még Balassi korában is számolni lehet. Vö. PIRNÁT Antal, Balassi Bálint poétikája, 51.

${ }^{370}$ BÓTA, i. m., 16.
} 
a szexuális vonatkozásokkal jóval telítettebb nyak jóval gyakrabban jelenik meg a Vásárhelyidaloskönyv anyagában, mintsem a Balassa-kódex oldalain. ${ }^{371}$

A következő strófa a viszonzott szerelem leírásához illő frázisokkal operál. Az előző két válaszlevélhez képest szembetűnő, hogy az aktuálisan fennálló távollét ezúttal nem vet árnyékot a beszélő kedélyére. Annak sem látszik különösebben szükségét érezni, hogy kedvesét vigasztalja v. szánakozást keltsen benne, inkább az érzelmek korábbi egyoldalúsága okozta sebek orvoslását várja tőle:

2. Legyen jókkal áldott,

Hogy hozzá fogadott

S kimentett kétségembül,

Mert hogy öt szerettem,

$S$ miatta epedtem,

Láthatja szemeimböl,

Azért már vigadok,

Mert oly hitben vagyok,

Hogy megment sebeimböl.

Ezekben a sorokban Bóta újfent több Balassi-párhuzamot vél felismerni. Egyrészt annak ekhós versének (Ötvennegyedik; Ó, magas kösziklák...) 23. sorával hozza összefüggésbe a tárgyalt éneket: ${ }^{372}$

Mert hogy így szeretem, s jutalmát nem érzem, oka talám nem is ö...

Másrészt az ötödik bejt (Ha nagy haragjában ...) 2. sorával: ${ }^{373}$

Azért mert csak ötet, senki nem egyebet vallok én asszonyomnak...

E megfigyelések jelentősége kevéssé magától értetődő; azokat a kritikai kiadás sem ismerteti. ${ }^{374}$ De még ha tényleges allúziók volnának is, a Balassi-versanyag ismereténél többet nem feltételeznek, az ahhoz való viszonyulásuk módjáról (az ún. szuggesztív hatás mibenlétéről ${ }^{375}$ ) a causa és a kifejtéséhez rendelt eszközkészletük alapvető különbözősége okán csak igen visszafogottan nyilatkozhatnánk.

Térjünk a befejezésre. A szerelmi válaszlevelek mikrokorpuszának első darabja ( $A z$ én szívem gyönyörködtetö szerelmesem ékes személyének kedves írására való választételem)

\footnotetext{
${ }^{371}$ A Régi Magyar Költők Tárának vonatkozó kötete (RMKT XVII/3) alapján az alábbiak szerint: „Vékony két karodat vesd nyakamon által...” (92/I. sz., 11. sor) „Nyakamot öleld meg kezeiddel...” (125. sz., 14. sor); „Szivem, vesd nyakamra gyenge karodat...” (130 sz., 9. sor); „Mindjárást ölelném gyenge szép nyakát...” (156/I sz., 25. sor); ,,Öleld meg, szivem, nyakamot...” (192. sz., 18. sor).

${ }^{372}$ BÓTA, i. m., 16.

${ }^{373}$ Uo.

${ }^{374}$ Vö. RMKT XVII/12, 736.

${ }^{375}$ BÓTA, i. m., 16.
} 
záróstrófájában egy közhelyes exemplummal biztosítja címzettjét együttérzéséről. ${ }^{376} \mathrm{~A}$ második (Szerelmesitől vált...) egy nem kevésbé topikus jókívánsággal rekeszti be mondanivalóját. ${ }^{377}$ A tárgyalt ének zárlata ezzel szemben ígéretek halmozásával buzdítja kedvesét érzéseinek cselekvő viszonzására, vagyis a válasz egészéből a protropé alakzata bontakozik ki:

3. Várjon víg örömmel,

Mert én is jó kedvvel

Megyek szép személyéhez,

S tehozzád is menten

Csókokkal békélem,

Jó hírt iró kezéhez,

Higgye bizonyosan,

Hogy én minden módon

Szabom magam kedvihez.

A mai olvasó számára a legföltünőbb szemantikai archaizmus e szakaszban a békél ige - ez a régiségben csókol jelentésben is használatos volt. ${ }^{378}$ (Vagyis a versszöveg értelme tkp. úgy foglalható össze, hogy ha a levélíró kéz a legközelebbi személyes találkozás alkalmával a hozzá tartozó karokkal együtt a beszélő nyakára fonódik, részesülni fog a kilátásba helyezett csókokból). Érthető, hogy Bóta is ennek keresi további előfordulásait a vizsgálata szempontjából releváns költői életművekben, méghozzá nem is eredménytelenül. ${ }^{379}$

A kifejezés megjelenik Balassi Harmincharmadik c. költeményének (Bocsásd meg, Úristen ...) 13. versszakában:

Térj azért, én lelkem, kegyelmes Istenedhez,

Szép könyörgésekkel békéljél szent kezéhez,

Mert ö hozzáfogad, csak reá hadd magad, igen irgalmas úr ez.

Szintén a kézcsókot írja körbe vele - tetejébe a szavakat Balassi szájába adva - Rimay az Epicédium nyitó tételének (Bocsásd Szent Lelkedet...) 24. versszakában:

Csókkal s áldásokkal

Szent kezedhez békélvén

Már útra indulok

Duna mellett lemenvén..

\footnotetext{
${ }^{376} \mathrm{Ld}$. a vonatkozó fejezetet.

${ }^{377} \mathrm{Ld}$. a vonatkozó fejezetet.

${ }^{378}$ Vö. a történeti-etimológiai szótár vonatkozó címszavával: TESz, I, 271.

${ }^{379}$ BóTA, i. m., 14. Érdekes, hogy az alábbi parallelizmusok közül Varga Imre a Balassi-citátumot elhagyja, noha egyedül abban figyelhető meg további szóhasználati megfelelés, mégpedig a hozzáfogad ige. Vö. RMKT $\mathrm{XVII} / 12,736$
} 
És ebben az értelemben használja a megkomponált versgyüjteményében is, a Világon, ég alatt... kezdetü ének záró versszakában (82-84 sorok):

Bátran hát székedhez,

Frigyszerzö kezedhez,

Ím, én most is békéllem...

Könnyü észrevenni, hogy e kollokáció a tárgyalt vers kivételével mindig istenes hangú énekekben jelenik meg. S ez a felismerés talán még jelentékenyebb a korabeli szerelmi költészet anyagában elvégzett ellenpróba fényében - márpedig ilyesforma szerkezet a Régi magyar költők tárának sokat idézett harmadik kötetében egyáltalán nem szerepel. A jelenségre nehéz kétségbevonhatatlan magyarázatot találni, de talán nem teljesen mellékes az a körülmény, hogy a TESz a békél kifejezés ebbéli jelentésének mindösszesen két előfordulását tudja adatolni a Winkler-kódex ${ }^{380}$ és a Nádor-kódex ${ }^{381}$ egy-egy passzusa alapján, és hogy mindkét szöveghely a Passió egy azonosítatlan, de bizonyosan közös forrásra visszavezethető részletének változatát adja. ${ }^{382}$ Feltételezhető ezért, hogy a szakrális kontextus irradiációja elég tartós volt ahhoz, hogy az archaikus szófordulat alkalmazhatósága elsősorban a kegyességi indíttatású lírikára korlátozódjék.

Mindazonáltal meg kell jegyeznem, hogy Bóta felsorolásából kimarad egy fontos tétel, éspedig a Nagyciklus Ötödik c. versének (Nő az én örömem) nyitó strófája.

Nö az én örömem most az én szép szerelmem erre való néztében,

Bús kedvem sincsen semmi énnékem, mert ismét bévett nagy szerelmében,

Megengedett, fogott kezet, megbékéllet nagy kegyesen,

Halálomtól megtéritett, engem csókolván édesen.

Ezzel kiegészülve az iménti hipotézis azt a régebbi vélekedést támasztaná alá, hogy Balassinál a vallásos és a szerelmi költészet frazeológiájának összemosásában a lovagi kultúra hagyományából eredeztethető koncepciózusság érhető tetten ${ }^{383}$ - mely törekvés egyes részeredményeit a tárgyalt vers szerzője bátran elkölcsönözhette anélkül is, hogy azok valódi nóvumát felismerte volna.

\footnotetext{
380 „A foldon ÿlwen hol vele bekelyk vala hol neky zolvala hol feiet hol orczaiat, hol kezeit hol labaÿt ees $Q$ derekat megh kemenÿeitwen chokolya vala.” Winkler-kódex:1506, kiad. PUSZTAI István, Bp., Akadémiai, 1988 (Codices Hungarici 9), 496. [116r]

381 „Mert nem illic vala hog ílen bínnel fortozot lelocnec zaíarol kí íne hog en aldot fíamat votte vala aldozatra es hog dragalatos zaíat megbekeltevala es meghlokoltavala." Nádor-kódex: 1508, kiad. PusZTAI István, Bp., Magyar Nyelvtudományi Társaság, 1994 (Régi magyar kódexek 16), 441. [107v]

${ }^{382}$ Ld. Pusztai Istvánnak a Winkler-kódexhez írott bevezetését. Winkler-kódex, 27-28.

${ }^{383}$ Vö. HORVÁTH Iván, Balassi költészete történeti poétikai megközelítésben, 203.
} 
A tizenöt szerelmes ének szakirodalmának áttekintése során korábban futólag már említettem, hogy a válaszlevelek funkciótörténeti horderejére - ha csak egy lábjegyzet erejéig is - Pirnát Antal is kitért Balassi Bálint poétikája c. kismonográfiájában. ${ }^{384}$ Nos, ezen a ponton nem kerülhetem meg e gondolatmenet tüzetesebb ismertetését. Pirnát a kora-újkori magyar nyelven írott szerelmi tárgyú verses levelek tradícióját tárgyalva érinti a szövegkorpuszt mint ismeretes, egy Horváth Ivánnal folytatott hosszas vita egyik szegmenseként. A vita komplex referálására nem szükséges vállalkoznom, hiszen azt egy rendkívül eruditív tanulmány részeként Tóth Tünde már régebben megtette. ${ }^{385}$ A szóban forgó (50.) lábjegyzetet viszont (a hivatkozásokat leszámítva) teljes terjedelmében idézem: „Balassi Bálint tehát, a Szép magyar komédia ajánlásában tett igérete ellenére »levélregényt«, szerelmes levelekböl álló versciklust nem irt. Pedig e müforma nem volt ismeretlen Balassi és reménybeli közönsége elött sem. Az Eurialus és Lucretia história egész második fejezetét ilyen verses levelek alkotják [...], s a mü befejezö, 5. része is tartalmaz egy szép szerelmi levélváltást. [...] A Balassi utáni költőnemzedék képviselöi közül pedig a Madách Gáspár által másolt ismeretlen alkotott három szabályszerü, Balassi strófában írt szerelmes levelet. „386

Valójában kérdéses, hogy a nevezetes ajánlásban beharangozott szerelmes leveleket ciklusba szerveződő versek formájában kell-e elképzelnünk egyáltalán. ${ }^{387}$ Pirnát felvetése viszont ettől függetlenül is kiváló ürügyet kínál a fent katalogizált, Balassi költői fellépését megelőző ill. követő szerelmi tárgyú alkotások alaki és tartalmi jegyeinek összehasonlító elemzésére; ráadásul egy olyan verstípus esetében, amelynek kifejlesztéséhez (a ránk maradt emlékek tanúsága szerint) Balassi alig járult hozzá. ${ }^{388}$

\footnotetext{
${ }^{384}$ A kérdést az Ércnél, kösziklánál... kezdetü énekről írott fejezetben is érintem; ld. ott.

${ }^{385}$ Vö. TóTH, $A$ virágének-vita, 133-146.

${ }^{386}$ PIRNÁT, Balassi Bálint poétikája, 100.

387 „Ha ez elsőben szerzett szolgálóleányom [ti. a Szép magyar komédia] kedves lészen kegyelmeteknél ezért az én szolgálatomért, rövidnap más szolgálót is szerzek kegyelmeteknek, ki nemcsak ékes énekekkel is, és valami dolgok az én szerelmemben megtörténnek, mindazokról írt szerelmes levelekkel gyönyörködteti tikegyelmeteket." MIŠIANIK, ECKHARDT, KLANICZAY, i. m., 50.

${ }^{388}$ Pirnát Antal igen szabatos definíciója is megengedné ugyan, hogy egynémely Balassi-éneket (jobbára a személyes hangvétel okán) levélként határozzunk meg (vö. PIRNÁt, Balassi Bálint poétikája, 32-34.) - sőt, egyes Nagyciklusbeli verstípusok természetes médiuma leginkább egy misszilis levél lenne; jellemzően ilyenek az ajándék- v. virágkísérő versek. Azonban olyan költeményt, amely explicit kijelentené tulajdon levél-voltát, a legnagyobb jóindulattal is csak egyet nevezhetünk meg: a Csák Borbála nevére szerzett Csak búbánat immár... kezdetü éneket (BÖM, 3. sz.), melynek utolsó, 48. sorában (,,Ki írta, tudhatod, hiszem mert látszanak könyveim ez levélben") a 'levél' szó valóban jelenthet többet a szimpla könyvészeti egységnél. Ezt a darabot a költő szintén ifjú barátja, Batthány Ferenc rendelkezésére bocsátotta, aki a versszakok sorrendjének megváltoztatásával ill. egyes strófák elhagyásával a maga kedvese, Éva nevére alakította az akrosztichonját. (Vö. ECKHARDT, A körmendi Balassa-emlékek, 43-45.) Az persze magától értetődik, hogy Balassi éppen ilyesfajta típusú írásokat küldjön, ugyanakkor igen érdekes, hogy Batthyányi a záró versszakot éppen nem emeli át a maga variánsába - különösen, ha hozzávesszük, hogy a Balassa-kódex örizte változatban ennek kezdőbetüje már nem része az integráns akrosztichonnak.
} 
Az Eurialus és Lucretia szerzője összesen tíz levelet szőtt bele a história textusába, melyeket a címszereplők egymásnak küldözgetnek oda és vissza. ${ }^{389}$ Azok közül tehát öt készült válaszlevélnek, ebböl négyet Lucretia jegyez. A Secunda pars négyötödét az első nyolc küldemény szövege teszi ki, a maradék kettő pedig az utolsó résznek képezi kevés híján a felét. Érdemes megfigyelni, hogy a beszélő előzetesen kizárólag az előbbi csoportot emlegeti föl (Prima pars): $:^{390}$

7. Azért most öt részre beszédemet rólok és az éneket osztom, Az elsö részében az ö szerelmeknek indulatját megmondom, Azután egymásnak küldött leveleket más részében megirom.

8. Sok szerencséjekröl és nagy szerelmekröl két részében éneklek, Utolsó részében szörnyü haláláról az asszonynak beszélek, Ha reá hallgattok, szerelem hatalmát ebböl megérthetitek.

Ennek alighanem az lehet az oka, hogy a história mint olyan természetszerüleg epikus költemény, márpedig - szemben az ötödik résszel - az Eurialus és Lucretia második részének elsődleges cselekménye valóban a levélváltásokban merül ki. A narrátor csak az egyes levelek részletes ismertetésén keresztül vezetheti be az olvasót a történet egészébe; bemutatva Eurialus hódító szándékú udvarlását valamint Lucretia reakcióit az elutasítástól az odaadásig. Ezt a megoldást az indokolja, hogy a viszony e kezdeti fázisában a szerelmesek között nyilván nem kínálkozik más lehetőség a kapcsolatteremtésre, csak a levelezés, és majd csak a beteljesedést leíró harmadik fejezetben nyílik alkalom számukra egymással szóba elegyedni attól fogva pedig a narrátor (noha több utalást is tesz arra, hogy a szerelmesek további leveleket is váltottak egymással ${ }^{391}$ ) már csak a dialógusok idézésében lesz érdekelt.

Jóllehet így van ez már Enea Silvio Piccolomini az Eurialus és Lucretia-históriának alapjául szolgáló prózanovellájában (Historia de duobus amantibus) is, mégis a Pataki Névtelen igényességét fémjelzi, hogy nem függő beszédben számol be a levelek tartalmáról, hanem önálló müalkotásokként dolgozza ki azokat, afféle lírai betéteket alakítva ki a kisepikán belül. ${ }^{392}$ Csakhogy a Historia prózai mü. A magyar változat szereplőinek viszont (lévén egy históriás ének alakjai) nem áll módjában másként megnyilatkozni, csak ha a szerző által választott formának megfelelően közlendőjük minden tizenkilencedik szótagja optimálisan háromszor összecseng.

\footnotetext{
389 Ezeket a szerző is számon tartja, vö.: „Negyed levelében eltitkolt szerelmét nyilvábban megjelenté...”, Eurialus és Lucretia históriája, secunda pars, 479. sor. (RMKT 9, 423.)

${ }^{390}$ RMKT 9, 405-406.

${ }^{391}$ Vö. Eurialus és Lucretia históriája, 346., 502. ill. 1397. sorok. (RMKT 9, 418, 424, 457.)

${ }^{392}$ Hovatovább mint retorikai teljesítménnyel büszkélkedik velük, vö. B. KIS Attila, SzILASI László, Még egyszer a Pataki Névtelenröl: Történeti poétika és dekonstrukció, névtelenség és dialogicitás, ItK, 1992, 666.
} 
Amivel csak arra szerettem volna felhívni a figyelmet, hogy egyrészt bizonyosan létezett nálunk a verses szerelmi leveleknek valamiféle szokásrendje az Eurialus és Lucretia előtt is, amelyből a Pataki Névtelen bizonyos toposzokat vagy formulákat meríthetett. Az első ránk maradt magyar nyelvü szerelmes vers (Emericus Terek köszön Krisztinának) is e körbe tartozik. ${ }^{393}$ Másrészt ezek a klisék szükségképpen keverednek azokkal a tartalmi elemekkel, melyeket a szerző a forrásmü tolmácsolása során avatott az alkalmi költészetben is könnyüszerrel applikálható mintadarabbá. ${ }^{394}$ A kettőt szétszálazni - tartok tőle - aligha lehetséges. $^{395}$

Az ekként összeállított fejezetekröl (Secunda ill. Quinta pars) most a következőket tartom fontosnak kiemelni. A levélbetétekben a szerelmesek nemigen mulasztják el a - fikció szerint valódi - nevén szólítani a másikat. ${ }^{396}$ Gyakran küldenek egymásnak ajándékot: gyürüket v. keresztet. ${ }^{397}$ Ám ha arról levelükben tesznek is említést egyáltalán, e mozzanat attól sosem válik a vers építményének egészét szervező alapötletté, szemben pl. Balassi hasonló típusú énekeivel. ${ }^{398}$ A maguk sorsát gyakran antik történetek höseinek ált. elrettentőnek szánt példáira hivatkozva igyekszenek alakítgatni. ${ }^{399}$ Eurialus fogalmazványai helyenként nem nélkülöznek bizonyos pajzán felhangokat. ${ }^{400}$ Végül pedig a levélváltásokban rendszerint nem a női szereplő a kezdeményező fél: ez alól csak az ötödik részben találni kivételt, melyben elsőként az erkölcseiből kivetkőzött Lucretia ragad tollat, miután tudomására jut a kedvesét tőle messzire elszólító diplomáciai küldetés híre. ${ }^{401}$

Ennek tükrében talán könnyebben formálhatunk véleményt a Madách-Rimay-kódexek vizsgált füzetének verses leveleiröl. A legfontosabb eltérés a két szövegcsoport között az, hogy ez utóbbinak bármiféle átfogó narratív vezérfonálra füzése merőben önkényes eljárásnak tünik. Ha viszont - csupáncsak a játék kedvéért - ezeket az énekeket mégis megpróbáljuk

\footnotetext{
${ }^{393}$ Ld. még az első éneket (Ne gondold, szerelmem....) tárgyaló részfejezetet.

${ }^{394} \mathrm{Az}$ Eurialus és Lucretia forrásfilológiájának kérdésköréröl ld.: MÁTÉ Ágnes, „Most kiváltképpen két ifjú személyének szerencséjét éneklem”: Bevezetés az Eurialus és Lucretia latin filológiájába, doktori értekezés, Szeged, 2010.

${ }^{395}$ Ld. még: G. CZINTOS Emese, A szerelem retorikája: A levélmüfaj alakváltozatai az Eurialus és Lucretiában = A történetmondás rétegei a kora újkorban, szerk. GÁBOR Csilla, Kolozsvár, Scientia, 2005, 141-171.

${ }^{396}$ Vö. Eurialus és Lucretia históriája, 217., 274., 292., 323., 349., 394., 487. ill. 1294. és 1318. sorok. (RMKT $9,413-423,453-456)$

${ }^{397}$ Uo., 301., 310., 390. sorok. (RMKT 9, 416, 419.)

${ }^{398}$ Ld. a Látod ez gyöngyszemet... kezdetü énekröl írott fejezetet.

399 A szerelmesek a levelezésben Jázon és Medea (secunda pars, 50. ill. quinta pars, 22. vsz.), Theseus és Ariadné (secunda pars, 51. vsz.), Dido és Aeneas (secunda pars, 52. vsz.), Sappho ill. Phillis (uo.), Troilus és Criseis (secunda pars, 72. vsz.), Deiphobusz és Heléna (uo.), Kirké (uo.), Antonius és Kleopátra (secunda pars, 74. vsz.), Portia (quinta pars, 21. vsz.) és Pénelopé (uo.) történeteit említik.

${ }^{400}$ Vö. Eurialus és Lucretia históriája, secunda pars, 36. vsz. (RMKT 9, 417.)

${ }^{401}$ Vö. Eurialus és Lucretia históriája, quinta pars, 3-11. vsz. (RMKT 9, 453-454.)
} 
elhelyezni az Eurialus és Lucretia c. históriában, úgy azt találjuk, hogy egyébként az utolsó fejezetben említett, de ki nem dolgozott levelekhez lehetnének hasonlatosak; hiszen azok is részben egy távol levő férfi hölgyének írott verses válaszai volnának. ${ }^{402}$

Elvben tehát az Ércnél kösziklánál..., a Szerelmesitől vált... és az Én édes jobb kezem... kezdősorú énekek (néminemü stiláris különbségeket figyelmen kívül hagyva) zökkenőmentesen beilleszthetőek egy olyan müegészbe, melyben nyilvánvalóan semmi keresnivalójuk nincsen - engedjük meg: nem is tudnak annak létezéséről. A magyarázat persze nagyon egyszerü: az utóbb tárgyalt három, vitathatatlanul jól felépített versike tartalma olyannyira neutrális, hogy azok bármelyike az imént részletezett, a szerelmi költészetben ráadásul igen gyakori alapszituációban lényegében akár változtatás nélkül is felhasználható. Márpedig ez a gyakorlat - ahogy az dolgozatom előző fejezetéből is kiviláglik ${ }^{403}$ - közel sem egyeduralkodó a kora újkor magyar nyelvü szerelmi-udvarló költészetének történetében. Ezért ismét csak nem zárhatjuk ki azt az eshetőséget sem, hogy az utóbb tárgyalt három akkurátus verses levél megírása során ez az univerzalitás is szempont lehetett.

\section{Összefoglalás}

A Madách-Rimay-kódexekben fennmaradt szerelmes énekeinek minden külső (paratextuális és strofikai) minőségét összevetve arra a következtetésre juthatunk, hogy azok közül a három egymást követő verses válaszlevél tartozik egybe legszorosabban, mintegy zárványt képezve a szövegek egységében. Ezt az érzetet a tartalmi megfelelések csak tovább erösítik. Valamiféle heterogenitás még inkább az elütő imitációs stratégiákból látszik kirajzolódni, mert míg az Ércnél, kösziklánál... kezdetü versike egy, a Vásárhelyi daloskönyvböl ismert közköltészeti alkotásban (Piros rózsa színü...) is előforduló közhelystrófára fut ki, addig a Szerelmesitöl vált ... a hatodik Célia-vers perorációját teszi meg kiindulópontul. Az előbbi tehát kifejezetten mint locus communis értékelhető, ezzel szemben az utóbbi több-kevesebb műgonddal applikált Balassi-reminiszcenciaként. De tegyük hozzá, hogy az Azmely keresztyén hü... kezdetű éneket maga a szerző adta ki a kezéböl - hogyha Battyhány Ferenc boldogulására is, és nem a Vásárhelyi daloskönyv névtelenjeinek inspirálására. Annak - valamint Balassi szerelmi költészete javának - popularizálódásában viszont ha nem is feltétlenül ez, de

\footnotetext{
${ }^{402}$ Igen érdekes kérdés, hogy a füzet három válaszlevelének mindegyikében szóba kerülő, alighanem fikcionális elözményeket - vagyis a hölgy(ek) leveleit - vajon rímesnek kell-e elképzelnünk.

${ }^{403}$ Ld. ott.
} 
mindenképpen a hasonló követési technikában érdekelt mutatványok játszhattak nagy szerepet. Márpedig ezek létrehozása legalábbis az egyes elődszövegek beható ismeretét feltételezi.

A jelen fejezetben tárgyalt ének esetében ilyen fokú szövegköziséget nem azonosítottunk, erröl tehát többet nem mondhatunk. 


\section{4. Örüll, immár, lelkem, szép kincset találtál...}

Az ének újfent (s egyben utoljára) a füzet anyagának leggyakoribb ritmus- és rímképlete szerint, vagyis négysarkú felező tizenkettesekben íródott. ${ }^{404}$ Sajnálatos módon öt strófa után a szöveg laphiány miatt megszakad, a hatodik szakasz első szavát csak az őrszóból ismerjük, de még ilyesforma töredékes voltában is a gyüjtemény leghosszabb versei közé tartozik. Azzal kapcsolatban, hogy mennyi veszhetett el belöle, és mennyi a füzet anyagának egészéböl, csak igen óvatos becslésekbe bocsátkozhatunk. A vers fölött a Maga lelke vigasztalásának 4 énekecske cím olvasható. A hiányt tehát legkevesebb három elveszett tételben állapíthatjuk meg - tekintve, hogy a következö s egyben utolsó poéma (Beborult, fölhözött, bánat hozó egem...) nem önmegszólító, vagyis e paratextus arra bizonyosan nem vonatkozik. ${ }^{405}$

Nem állapítható meg, hogy kell-e további veszteségekkel számolnunk. Egyrészt az elkallódott levél párja sem maradt ránk, ezért nem tudhatjuk, volt-e azon versszöveg (értsd: eredetileg is a $\mathrm{Ne}$ gondold, szerelmem... kezdetü ének lett volna-e a nyitódarab). Másrészt abban sem lehetünk teljesen biztosak, hogy a csonkulás mindössze egyetlen levélpárnyi terjedelemre korlátozódik. ${ }^{406}$

Az előző fejezet összegzésében arra a megállapításra jutottam, hogy a füzet jelenlegi állapota szerint a versek közül a három válaszlevél tartozik össze a legszorosabban. A Maga lelke vigasztalásának 4 énekecske felirat ugyanakkor nem a tárgyalt ének egyedi címe, hanem egy rövidebb ciklus emlékét örzi; vagyis az egészében csak lazán összefüggő gyűjtemény épületébe több önálló szövegcsoport is tartozhatott.

Az ismeretlen szerző ezzel a címadással akárha a soliloquium műfaját igyekezne némiképp perifrasztikusan - magyarítani. A korábbi szakirodalomban a tárgyalt ének lehetséges mintáiról érdemben nem esik szó, ${ }^{407}$ de verses magánbeszéd másképpen szintén maradt fenn a Madách-Rimay-kódexekben: a harmadik kötet két, egyenként mindössze négynégy keskeny levélből álló kis füzetkéje őrzi Rimay János egy elveszett latin nyelvű énekének

\footnotetext{
${ }^{404}$ Kritikai kiadása: RMKT XVII/12, 56. sz.

405 Ezt a vonatkozó kritikai kiadások sajtó alá rendezői (Eckhardt ill. Varga) nem így tudják. A kérdésről részletesebben ld. a 437. lábjegyzetet.

406 A füzet egy lapján kilenc darab négysarkú strófának úgy jut hely, ha azok semmilyen módon nincsenek elkülönítve egymástól (vö. 16r). Ezért az elveszett levélre a címben jelölt további három „énekecske” csak úgy fér ki, ha azok terjedelme nem éri el az itt tárgyalt versét $(\geq 6)$.

407 Szakirodalom alatt ezúttal is elsősorban Bóta László tanulmányát, Varga Imre kritikai jegyzetapparátusát ill. Nagy Ferenc szakdolgozatát értem. Vö BÓTA, i. m.; RMKT XVII/12; NAGY, i. m.
} 
fordítását Madách Gáspár fogalmazatában és tisztázatában. ${ }^{408} \mathrm{Ez}$ a költemény a Soliloquium Johannis Rimaini címet viseli. A szövegek közelsége okán azt gondolom, hogy Madách Rimay-fordításának (Miért törödöl, én lelkem...) és az ismeretlen szerző énekének (Örüll immár, lelkem...) összevetése bizonyosan szolgál valami tanulsággal a tárgyunkra nézve.

A strófákra nem tagolt (zömében pontos) nyolcasokban írott Soliloquium véglegesített változata kereken 120 sort tesz ki, ezért annak közlésétől pusztán helytakarékosságból tekintek el, az alábbiakban csak néhány jellemzőjét foglalnám össze. A költemény szó- és képhasználata a kor meditációs irodalmának frazeológiáját követi. Szerkezetileg a közönséghez fordulás alakzatainak váltakozása mentén négy fő részre osztható; ezek általában a kéziratban is elkülönített tömböket alkotnak. Az első (1-40. sorok) alapszituációja a tényleges önmegszólításé, s ez a törődött lélek invokációjában fejeződik ki. A beszélő arról igyekszik tulajdon lelkét meggyőzni, hogy megnyugvást csak akkor találhat, ha továbbra is rendületlenül bízik Istenében. S hogy ezt nem hiába teszi, arra természetesen Krisztus keresztáldozata a bizonyíték - vagyis a causa jellege müvészi argumentációt eleve nem igényelne sem itt, sem a későbbiek folyamán. A kommunikációs helyzet először a 41-64. sorokban változik. Ebben a szakaszban a beszélő már többes szám első személyben fogalmazva (vagyis egy adott közösség nevében) tesz hitvallást, ennek következményeként a magánbeszéd némiképpen a gyülekezeti énekköltészet hangütésének irányába mozdul el, és a megváltástan főbb tételeit enumerálja. A következő két egység újra a személyes áhítat formáit ölti magára: a harmadik rész (65-98. sorok) a konfesszióét, melyben a beszélő saját gyarlóságát vallja meg (szintén felsorolás gyanánt) a Teremtőnek; végül a negyedik (99-120. sorok) a könyörgését, melyben viszont már a megváltó Fiúistenhez fohászkodik lelkének üdvözségéért. E tipológiai sokrétüséget figyelembe véve ezért egyáltalán nem túlzás azt mondani, hogy a müfajelméleti vonatkozású Soliloquium címfelirat egyenesen félrevezető is lehet. $^{409}$

A vizsgált ének ehhez mérten pragmatikailag simplex felépítésü, tematikai szempontból azonban összetettebbnek bizonyul. Abban ugyanis kétségkívül az a poétikai alapkoncepció a legfigyelemreméltóbb, miszerint a szerelemi témakörhöz jól társítható a meditációs költészet

\footnotetext{
${ }^{408}$ Madách-Rimay-kódexek, III, 8r-11v [tisztázat], 14r-17v [fogalmazat]. A tisztázott versszöveg alatt a következő bejegyzés olvasható: „Forditottam én, Madách Gáspár deákbúl magyarra Rimay uram verseiből.” Kritikai kiadása: RMKT XVII/12, 7. sz.

${ }^{409}$ Ács Pál korábbi megfigyelése, hogy a Rimay-verscímek retorikai müfajmegjelölő érvénnyel is bírnak, s ez alapján a Soliloquium a tanácsadó beszédnemhez tartozik (vö. Ács Pál, Ratio és oratio, 272.) - ugyanakkor ahhoz a fentiek szerint nagyobb, szépséget ill. rútságot ábrázoló tömb is társul, vagyis a költemény egyúttal a genus demonstrativum körébe is osztható.
} 
illusztris műfaja ${ }^{410}$ - méghozzá úgy, hogy annak tartalmából (a fennmaradt részben legalábbis) mindenestül hiányzik a kegyességi szemlélet.

A vers tehát a beteljesedett, boldog szerelmi kapcsolat leírásában érdekelt; bókolásra és/vagy udvarlásra ezért csak e feltételek teljesülésével használható. Szövegében a beszédnemek ezúttal is keverednek: a beszélő egyrészt önnön lelkét szándékszik rábeszéléssel (suasio) indulatba hozni, másrészt a bíztató előzmények bemutatásával (laus) részletezi, mi oka lehet az örömre. A szereposztás tehát kissé eltér a megszokottól, hiszen a kor szerelmi költészetének konvenciórendszerében általában a lélek a személyiség azon értelemmel fel nem ruházott része, amelyet ebből kifolyólag gyakran az észérvekkel szemben is magukkal tudnak ragadni az érzelmek. Ehhez képest már a felütéstől kezdve olybá tünik, mintha jelen esetben - kissé ormótlanul - a beszélőnek mégis a viszonzás időszerüségéről kéne meggyőznie magát; mintha legalábbis félő volna, hogy a végén még elmulasztja a megfelelő alkalmat a szerelembe esésre:

1. Örüll, immár, lelkem, szép kincset találtál,

Ki keresetiért hegyet, erdöt jártál,

Nem esett heába, hogy érte fáradtál,

Hozzád érkezett már, kit óhajtván vártál.

A nyitóképek természetközelisége ha egészen megkapó is, azonban mégsem teljesen problémátlan. Erre egy korabeli szövegpárhuzam segítségével szeretnék rávilágítani. Wathay Ferenc $O$, te én bolond elmém... kezdetű versének köztudottan az az alapfikciója, hogy a szeretett feleségétől elválasztott, szülöföldjéről elhurcolt s a Fekete toronyba zárt rab éjjelente hazagondol, s ezért aztán nem tud aludni. Ezt a szerző a következő allegória mentén dolgozza ki. A nyughatatlan szív parancsára az elme ilyenkor felkerekedik, s a Márvány-tenger partjától a Rába vidékéig száguld, a családi birtokra. A kialvatlanság és a honvágy gyötrelmeit illusztráló képek egyre plasztikusabban jelennek meg, amitől is a korban elképzelhetetlen tempójú utazás mind valóságosabbnak tünik. Ezzel egyidejüleg pedig az elme fokozatosan egy fizikailag is létező, szuverén entitás képzetét kezdi kelteni, akit félteni lehet, sőt kell az éjszakai száguldozástól - és a vers beszélője ekkor (az aktuális metaforika érvényét egy pillanatig fel nem adva) ráébred, hogy talán csakugyan elment az esze: ${ }^{411}$

15. Ódd magad, mert ha vessz, hidd, én megbolondulok,

Látod-e, már rég is, mely gyakran miket szólok,

\footnotetext{
${ }^{410}$ KlANICZAY Tibor, A meditatív költészet: a manierizmus reprezentatív müfaja $=\mathrm{K} . \mathrm{T}$., Pallas magyar ivadékai, Bp., Szépirodalmi, 1985,124-128.

${ }^{411}$ WATHAY Ferenc Énekes könyve, szerk. KATONA Tamás, Bp., Magyar Helikon, 1976, I (fakszimile kiadás), 73r, ill. RMKT XVII/1, 45. sz.
} 
Ha elmém sem volna, olyat níha gondolok.

Beláthatjuk tehát, hogy a költői nyelv grammatikalitása és retoricitása közti feszültséget a tárgyalt vers szerzője (szemben Wathayval) nem hogy nem kamatoztatja, de nem is nagyon látszik tudomásul venni; ${ }^{412}$ ebből adódóan a hegyen-völgyön át kincset kereső lélek szóvirágai afféle képzavarként (catachresis) is értékelhetőek.

A második strófa a keresett kincsnek a mibenlétét hivatott szemléltetni:

2. Gyöngyöt és aranyat meghalad szépsége,

$S$ drágább mindazoknál hozzád való kedve,

Minden kétséged már legyen eltemetve,

Mert nála asztalod készen vagyon vetve.

Bóta elöször a hatodik sorban mutat rá egy a Rimay-életmüben is fellelhető fordulatra, a korábbiakban már érintett versmondatban: „Mert áldott szerelme / S hozzád való kedve / Hü leszen $s$ rád bút sem hoz." "413 (Szólitván nevemen..., 88-90. sorok.) A szerkezet megjelenésének esetlegességét már az előző fejezetben is hangsúlyoztam. ${ }^{414}$

A tárgyalt ének kapcsán Bóta egy további szóelőfordulást emel ki: arra figyelmeztet, hogy míg a Rimay által gyakran használt jel névszó sem Balassi, sem Madách Gáspár lexikai készletében nem szerepel, addig az Örüll immár, lelkem... tizenkettedik sorából szintén adatolható: ${ }^{415}$

3. Valamit felöle hozzád reménlettél,

Mindeneket benne bévséggel felleltél,

Szive titkában is már részessé löttél,

Sjó akaratjárúl bizonyos jelt vettél.

Ez a kijelentés azonban nem állja meg a helyét. Az ugyan igaz, hogy a kérdéses kifejezés Madách verses munkáiban nem jelenik meg, ${ }^{416}$ ám Balassi esetében (a Szép magyar komédiát

\footnotetext{
412 Vö. Paul DE MAN, Az olvasás allegóriái, ford. FOGARASI György, Szeged, Ictus-JATE, 1999 (deKONkönyvek, 17), 13-34.

${ }^{413}$ BÓTA, i. m., 14.

${ }^{414}$ Ld. ott.

415 „, Tartsa jelül magán érte kifolt véremet” (Bocsásd Szent Lelkedet..., RÖM, 1/I sz., 190-191. sor); „,Ez az jele, hogy szán életem igen téged” (Ihon, édes hazám..., RÖM, 1/III sz., 2-3. sor); ,,Jelt arról éltében gyakran is mutatott” (Delos szigetéböl ez minap Dianna..., RÖM, 1/V sz., 33. sor); „,Sok jelekböl rajtam szemekkel is lássák” (Az jó hitü ember..., RÖM, 21. sz. 55. sor); „Ez feltetszett jelünk, hogy Isten vezérünk” (Minden dolgok között..., RÖM, 26. sz., 33. sor); ,,Nálad, hogy szeretlek, legyen ez vers jelem” (Ó szegény megromlott..., RÖM, 37 sz., 28. sor). Vö. BÓTA, i. m., 17.

416 „, Küldöttenek mindazonáltal az doktorokért, nem találván semmi oly betegségnek jelét és okát rajta, kiböl vélhetnék eredetit nyavalyájának...”, (Madách-Rimay-kódexek, II, 154); „Egynéhányszer akartam az én szívemnek, belsö szerelmemnek jelét megjelentenem, de az asszonyemberi szemérmetesség megelözött engemet...”, (Madách-Rimay-kódexek, II, 155). Kritikai kiadását ld.: RMKT XVII/12, 698-699.
} 
nem számítva) háromszor is. ${ }^{417}$ Ami természetesen Bóta állítását legfeljebb árnyalja, de nem cáfolja - azzal együtt pedig jól mutatja, mennyivel könnyebb dolga van e dolgozat írójának a szövegelemzéssel a digitális korszakváltás után.

Már csak emiatt sem szeretném elhallgatni egy, a tárgyalt ének nyolcadik sorát illető, $\mathrm{s}$ mint olyan, Bóta érveit gyarapító észrevételemet. Az abból kiragadható 'asztal' szó semmilyen alakban nem eleme Balassi alkotásainak, és Madách Gáspárnak is csak a szórakoztató hazugságmondások ellen írott Krónika címü versében található meg; ezen belül kétszer is. ${ }^{418}$ De a fent olvasható 'vetett asztal' szintagma a vizsgált körben egyedül csak Rimay Jánosnál érhető még tetten - méghozzá egy, a kizárólag a Madách-Rimay-kódexekben hagyományozódott verse, az Encomia et effecta virtutum kezdősoraiban:

Itt egy asztalt látunk körül telepedve,

Akire szép hímes abrosz vagyon vetve...

A merőben eltérő kontextus azért is jelentőségteljes, mert annál semmi sem mutatja jobban, hogy noha az Örüll immár, lelkem ... kezdetű ének a vonzalmak kölcsönösségéről számol be, a szerelmi viszony ábrázolásából mindazonáltal teljesen hiányzik a testiség minden aspektusa. Példának okáért a korábban már többször idézett Eurialus és Lucretia-históriában a kevéssé szemérmes hősszerelmes már az első levelében nyíltan tudatja szándékát Menelaus hitvesével - ami szerint kiszemeltjét egy határozottan eltérő rendeltetésủ bútordarab igénybevételével óhajtja vendégül látni: ${ }^{419}$

Mind éjjel, mind nappal tégedet kivánlak, várlak az én ágyamban.

Abban persze nincs okunk kételkedni, hogy - szemben Madách Gáspár praxisával ${ }^{420}$ - hogy a tárgyalt versben a kedves szépségének méltatása ne esztétikai alapon történnék meg, ugyanakkor a habitus corporis kifejtésében rejlő lehetőségeket e töredék szerint a beszélő (ill. a szerző) nemigen aknázza ki; a költeményben jobbára csak a belső tulajdonságok kerülnek részletezésre. Így van ez a negyedik strófában is:

4. Örüll, vigadj azért immár szépségének,

És szolgálj örömmel mindenben kedvinek,

Neveld indulatját hozzád szerelminek,

\footnotetext{
417 „,Mert minden szépségnek jelit rajta látom” (Mondják jövendölök bizonnyal.... BÖM, 2 sz., 32. sor); „,Kivel szívemet, mint célül tett jelt lövi, hogy kínt valljon” (Áldott Julia kiballagtába..., BÖM, 59. sz., 15. sor); „,Cupido, nyiladnak magam vagyok-é csak célül támasztott jele?” (Kit csak azért mível..., BÖM, 77. sz., 3. sor). ${ }^{418}$ „Nincs rútabb dolog az hazugságnál, / Föképpen nagy urak asztalánál” ill. „,Ez mondásokat meg is újítják, / Urak asztalánál hittel bizonyitják”. RMKT XVII/12, 38/I, 17-18.,77-78. sorok.

${ }^{419}$ Eurialus és Lucretia históriája, secunda pars, 231. sor. (RMKT 9, 413.)

${ }^{420}$ A kérdésről bővebben ld. az appendixet (A Rimay-örökség Madách Gáspár tollán).
} 
E kívánalmak megítéléséhez elengedhetetlen az emberség fogalmának pontosabb körülhatárolása, ez a kifejezés ugyanis a kora újkorban sokféle jelentésben volt használatos 421 ennek megfelelően Balassi költői nyelvében is változatos értelemmel bír. ${ }^{422}$ Írásaiban jelenthet illendőséget v. udvariasságot (vö.: „Erkölcse szelíd és szemérmetes, emberséggel elegy...”; ${ }^{423}$ ill. „Mirtina ottan felkele, s nagy emberséggel kezde étellel és itallal kínálni bennünket. "424) Jelenthet együttérzést, jóindulatot v. segítőkészséget (vö.: De hogy búmban így hágysz, s még csak ingyen sem szánsz, az-é a jó emberség?”; ${ }^{425}$ ill. „Ne gondold, oly könnyen ez véghez mehessen, nem fér emberségedhez... ${ }^{, 426}$ ). És akár - jóllehet a szerelem témaköréből kitekintve, de a teljesség kedvéért meg kell említenem - jelenthet bátorságot v.

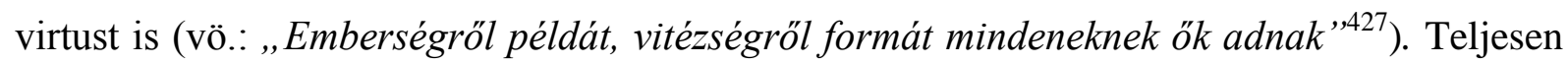
más a helyzet a Rimay-versanyag esetében, melynek összeszerkesztésében ez a szó - ahogy arra Bene Sándor dolgozatom egy korábbi fejezetében már említett tanulmányában rámutat ${ }^{428}$ - alighanem kulcsszerepet tölt be. Az általa a Rimay János alkotásainak összességében „, intellektuális csomópontként” tételezett Szép egynéhány szerelmes versek c. költemény (Én édes Ilonám...) 5. sora ugyanis így hangzik: ${ }^{429}$

Szép szád teljes mézzel, nyelved bölcs beszéddel, nagy is az emberséged...

Ez ügyben most tehát elkerülhetetlen Bene monográfiányi értelmezésének idevágó téziseit referálnom. Az idézett jellemzés tárgya és címzettje köztudottan egy bizonyos Ilona - mely elnevezésben a szöveg modern kori recepciója vélhetőleg azért nem ismerte fel a mitológiai allúziót, mert a görög királynéra a homéroszi hagyomány szerint az idézett tulajdonságok (a szépség kivételével persze) nem látszanak ráilleni. Csakhogy a Heléna-mítosz többek között Euripidész által is feldolgozott alternatívája ezt a problémát lényegében kiiktatja; hiszen e változat summája éppen az, hogy Helené, a hủséges feleség a bölcsessége révén képes

\footnotetext{
${ }^{421}$ Az Erdélyi Magyar Szótörténeti Tár vonatkozó szócikke értelmében: becsület; tisztesség; tekintély; vkinek ember volta; emberiesség; illendőség; vkinek testi-szellemi ereje; figyelmesség. Vö. Erdélyi Magyar Szótörténeti Tár, 3, szerk. SZABÓ T. Attila, Bukarest, Kriterion, 1982, 156-157.

${ }^{422}$ Vö. a Balassi-szótár vonatkozó címszavával. Balassi-szótár, 110.

${ }^{423}$ Beteges lelkem ismét énnékem..., BÖM, 1. sz., 10. sor.

${ }^{424}$ MišianiK, ECKHARDT, KlanicZAY, i. m., 89. (Actus IV., Scena I.) Az idegennyelvű minta, vagyis a Castelletti-pásztordráma „,con human sembiante” (a. m. látható jóindulattal) kifejezést fordítja az 'emberség' szóval a költö. Vö. Cristoforo CASTELLETTI, L'Amarilli, Vinegia, Giovanni Battista Sessa \& fratelli, 1587, 132r.

${ }^{425}$ Tebenned, Julia, mind világ csudája ..., 3. sor. (BÖM, 47. sz.)

${ }^{426}$ Hozzám követséggel küldte..., 15. sor. (Kritikai kiadását ld.: ÖTVÖs Péter, A Csáky-énekeskönyv, ItK, 1980, 505.)

${ }^{427}$ Vitézek, mi lehet..., 14. sor. (BÖM, 68. sz.)

${ }^{428}$ BENE Sándor, Rimay Múzsája, ItK, 2011, 287-288.

${ }^{429} \mathrm{RÖM}, 16 . \mathrm{sz}$.
} 
ártatlanságát megőrizni. Ráadásul a Rimay-korabeli latin fordítások olyan kifejezések segítségével ültetik át a Helené c. dráma a címszereplőt méltató zárlatát (generosi, nobilissimi animi), melyek magyar megfelelőjét ugyanakkor kimerítheti az emberséges jelző.

A Szép egynéhány szerelmes versek ügyében nincs okunk abban kételkedni, hogy a Balassa-kódexben fennmaradt több szerelmes énekével együtt Rimay - a fikció szerint mindenesetre - ezt az udvarló költemény is tisztességes (honestum), értsd: házasodási célzattal írta volna. ${ }^{430} \mathrm{~A}$ fenti párhuzam tehát arra világít rá, hogy nagyon is evidens, ha a választott hölgy nevéből ilyen érdekböl kovácsol valaki pozitív személyi argumentumot. Azonban hogy a nomen miért erősíti meg egyúttal azt is, hogy viselője egyúttal a Múzsa szerepének betöltésére is alkalmas, annak hátterében egy, az Iszokratész Heléna-enkómiumára tett utalás valószínüsíthető - a rétor érvelése szerint ugyanis ezt kellőképpen bizonyítják azok a homeridák, melyek szerint az Iliász ihletője éppen Helené lett volna.

Mindez a Rimay-életmüben ott látszik nagyobb összefüggéseket teremteni, ahol egybeér Justus Lipsius a költőnk számára eszmeileg alkalmasint a legnagyobb inspirációt képező De Constantia c. értekezésének azon passzusával, amely az Odüsszeia negyedik énekét idézi; azt a részt, melyben Helené a múltidézés fájdalmait népenthesz itatásával orvosolja - ennek értelmében tehát a múzsák itala a sorscsapások között hányódó lélekben is képes helyreállítani a belső egyensúlyt. Márpedig erről a toposzról Rimay az elmélkedő költészetében is számot ad, méghozzá (úgyszintén Lipsiust követve) az ember és az Isten közti béke viszonylatába helyezve azt - melynek kifejtése során újabb árnyalattal gazdagítja az emberség terminus jelentéskörét. Természetesen a Sibi canit et Musis c. verséről van szó: ${ }^{431}$

8. Kevés lábnyom járja ugyanis az utat, Mellyen nyomozhatni Castalius kutat, Gond, veriték, munka lassan hozzá juttat, De fáradtságodban, higgyed, meg is nyugtat.

9. Elmét ennek vize hint gyönyörüséggel, Lelki háborút olt, s táplál csendességgel, Tudománt együtt ád kedves bölcsességgel, Közlet emberséget közel istenséggel.

\footnotetext{
${ }^{430}$ Vö. JANKOVITS László, Soliloquium és oratio Rimay egy versében, 217.

${ }^{431}$ Kritikai kiadása: RÖM, 61 sz.. Itt jegyzem meg, hogy e verset igen érdekes lenne összevetni gróf Balassa Bálint Botlasz-e, vagy már régen el is estél... kezdetü énekével, ti. az voltaképpen ugyanennek a toposznak a palinódiájaként is értékelhető. Az utóbb említett költemény kritikai kiadását ld.: RMKT XVII/12, 94. sz.
} 
A tárgyalt vers releváns kontextusainak vizsgálatával feltárt eredményeink - kár is lenne tagadni - meglehetősen ortodox képet festenek Balassi Bálint és Rimay János költészettörténeti szerepéröl. Hiszen amíg az elöbbi elsősorban a legfontosabb lovagi erényeket: az udvariasságot, a könyörületességet és a vitézséget kapcsolja össze egy/a bizonyos szó különféle jelentésrétegeiben, addig utóbbi ugyanazzal az újsztoicista morálfilozófia egyik - fent részletezett - alapfogalmát igyekszik meghonosítani.

Mindez számunkra e tárgyban azért érdekes, mert az emberség kifejezés az Örüll immár, lelkem... kezdetü énekben is nagy hangsúlyt kap, lévén az ötödik strófában a beszélő a dubitatio eszközét alkalmazva a konkretizálás igényével tér rá vissza:

5. Nem emberség-e ez, hogy rajtad könyörült,

S könyörülésébül vigasztalást is küld?

La, mely szelégy hozzád, töled meg nem rémült,

Jelentvén, hogy ö is szerelmedben merült.

Idézett tanulmányának egy számunkra fontos pontján Bene leszögezi: nem vonja kétségbe Bóta legfőbb állításának igazát; vagyis megengedi, hogy a Madách-Rimay-kódexek szerelmes verseit Rimaynak tulajdonítsuk. ${ }^{432}$ Ebben a kérdésben - nem győzöm hangsúlyozni - magam sem tudok határozottan állást foglalni. Mindössze arra szeretném felhívni a figyelmet, hogy a tárgyalt vers szóhasználata szerint az emberség (bármit is jelentsen az pontosan ehelyütt) bizonyítéka a könyörületesség - ez a szinekdoché pedig szemantikailag inkább mutat hasonlóságot a Balassi Bálintnál, semmint a Rimay Jánosnál tapasztalható gyakorlattal. E megfigyelést azonban tovább precizírozni a költemény töredékessége okán nem lehet: az ugyanis itt szakad meg; a hatodik strófából csak az őrszó (Kívánja...) maradt fenn. $^{433}$

A lezáráshoz érkezve az ének funkciójára nézvést további adalékkal szolgál, hogy a pars pro toto felismert könyörületességre egy signum enged következtetni, jelesül hogy a szeretett hölgy előzőleg vigasztalást küldött kedvesének. A 17. század költészeti anyagának tanúsága szerint - nyilván a vallási tematika túlsúlyából adódóan - a kora újkori szubjektum vigaszt elsősorban persze Istentől vár: vagyis a dolgok jobbra fordulását végső soron a gondviselésnek (tehát Isten cselekvő tevékenységének) hajlamos betudni. Ezzel szemben az

\footnotetext{
${ }^{432}$ BENE, i. m., 314-315., 193. lábjegyzet.

${ }^{433}$ Efféle terminológiai koncepciózusság a kor további szerelmi tárgyú alkotásaiban nem tapintható ki. A Pataki Névtelen a kifejezést pl. egyáltalán nem használja. Madách Gáspár is csak egy helyütt, a Libellus Elegantissimus I. könyvének 25. disztichonjának megrímelése során - jellemző módon egyszerűen átvéve a debreceni kiadás prózafordításából: „Azmit egyszer adhatsz, kétszer ne ígérjed, / Senkinek ígérni azont ne is merjed, / Emberségedet inkáblan neveljed, / Eszelös voltodot bánjad, hogy elterjed.” (RMKT XVII/12, 34. sz., 24.) vö. „Azmit (egyszer) megadhatsz, kétszer ne igérjed senkinek, / Ne légy szeles (állhatatlan), mikor emberségesnek akarsz látszani." (Libellus Elegantissimus, A7r)
} 
emberséges vigasztalás jobbára verbális természetü. ${ }^{434}$ Nincs okunk azt feltételezni, hogy ez alól az Örüll immár, lelkem... kezdetü vers kivétel volna. Márpedig szerelmesek között a vigasztaló szavak küldésének legtriviálisabb módja a levélírás. Ami egyben azt is jelenti, hogy a tárgyalt ének a vizsgált gyüjteményben a szerelmi levelezésre utaló darabok számát gyarapítja - immáron hetedikként.

\section{Összefoglalás}

A Madách-Rimay-kódexek tizenöt szerelmes verset őrző füzetének csonkasága okán a Maga lelke vigasztalásának 4 énekecske cikluscím alatt csupán egyetlen, az Örüll immár, lelkem... kezdetű költemény maradt ránk, mely verstechnikailag ill. retorikai felépítésében e korpusz kezdetlegesebb alkotásai közé sorolható. Meglehet ugyanakkor, hogy ismeretlen szerzőjének kísérletező kedve azok helyett inkább a müfajiságban rejlő lehetőségekre irányult, vagyis költői teljesítmény gyanánt elsősorban a sztoikus elmélkedő líra tárgykörének kiterjesztését kell értékelnünk.

A versgyüjtemény megítélésének szempontjából érdekes továbbá az is, hogy a versszöveg egy fordulata révén (,,könyörülésébül vigasztalást is küld”) az önmegszólító beszélő mondanivalója ismét a szerelmeslevelek - engedjük meg: fiktív - kontextusába ágyazódik be és válik mintaértékűvé.

\footnotetext{
${ }^{434}$ Vö. Rimay János Hatalmaskodók ellen c. versének (Ha az Isten nékem...) kolofónjával: „Buchananus verssel / Deákul illy renddel / Ezt az zsoltárból írá, / Most penig magyarra, / Vigasztalására / Elmém megtolmácsolá / Az magyar igéknek / Folyásához, s ennek / Értelmét helyén hagyá.” (RÖM, 32.)
} 


\section{Beborult, fölhözött, bánat hozó egem...}

A gyüjtemény záróverse a tizenöt között - az Oly nehéz nem látnom... kezdetű után - a második, mely rím-és ritmusképletében az ún. Palkó-éneket követi. ${ }^{435}$ Nyolc strófából áll, s ezt a terjedelmet a korpuszban csak az első darab (Ne gondold, szerelmem...) haladja meg, ami - bizonyos további hasonlóságok figyelembe vételével - akár többre is utalhat a puszta véletlennél.

Ezekben a rövidesen bemutatásra kerülő jellemzőkön kívül a két énekben még az is közös, hogy mindkettő bejegyzése elött levélhiány mutatkozik. Ebböl fakadóan eleve kérdéses lehet, hogy a két költemény jelenlegi keretes elhelyezkedése a füzetben megfelel-e az eredeti szerkezetnek. A Ne gondold, szerelmem... esetében - mint ahogy azt a vonatkozó részfejezet elején is említettem - nem zárható ki az a feltételezés, hogy a csonkulást megelőzően a gyüjtemény egy (vagy akár több) másik, elveszett darabbal kezdődött volna; vagyis annak nyitó pozíciója esetleges. A tárgyalt versnek azonban a fogyatkozások elött is záró helyzetben kellett állnia, amit nemcsak az támaszt alá, hogy a következő lap üresen maradt, s végül Madách tollpróbái kerültek reá, de az a tény is, hogy az oldaltükre aljában szemben az összes többivel - nincsen őrszó.

A szöveg kritikai kiadását sajtó alá rendező Varga Imre a fogyatkozások miatt azt valószínűsíti, hogy e versnek (akárcsak a $N e$ gondold, szerelmem... kezdetűnek ${ }^{436}$ ) hiányzik az eleje. Vargának jó eséllyel lehet igaza, hiszen az anyag másolója, Madách Gáspár egyébként - vagyis azon énekek tanúsága szerint, melyeket fizikailag nem előz meg laphiány - sosem mulasztotta el feltüntetni a müvek címfeliratát sem; ha másként nem, legalább a Más paratextussal jelölve az egyes tételek önállóságát. Az érintett alkotások esetében tehát minimálisan ennyinek valóban el kellett vesznie, ámde önmagában véve ez nem feltétlenül jelent egyet a versszövegek töredékességével.

Itt jegyezném meg, hogy egy újabb kolláció eredményeként Nagy Ferenc a dolgozatában némiképpen pontosította a kritikai kiadás korábbi megállapításait. ${ }^{437}$ Ennek

\footnotetext{
${ }^{435}$ Kritikai kiadása: RMKT XVII/12, 57. sz.

${ }^{436} \mathrm{Ld}$. a vonatkozó részfejezetet.

${ }^{437}$ A kérdést az előző fejezetben is érintem. Az a tény, hogy a kolligátum többi füzete jobb állapotban maradt ránk, leginkább arra utal, hogy ezt (még mint önálló egységet) forgathatták a legtöbbet. A korábbi autopsziák mindenesetre a következő eredményeket hozták: „A Rimay János hátrahagyott minkái 1-ső kötet jelzésü gyüjtemény hosszúkás, kb. $203 \times 80 \mathrm{~mm}$ alakúra összehajtott papirból csinált füzetekböl áll, melyek többnyire egymástól eltérö alakúak és vízjelüek. [...] II. Barnás, más vízjelü papír, nincs ceruzával keretezve (31-42.).
} 
értelmében a füzet első tizennégy verse összesen négy (azaz két pár) levélnyi helyet vesz igénybe. Ezt az egységet a köttetés során duplán betétlevelek közé foglalták, s e betétleveleknek a két rétege közé került - egyértelmüen jelezvén a folytonossági hiányt - az a levélpár, mely harmadik lapján (a második levél verzóján) tehát az itt tárgyalt verset hordozza. Kiegészítve a könyvtári folio-számozással, ezt az alábbi ábrával szemléltetném:

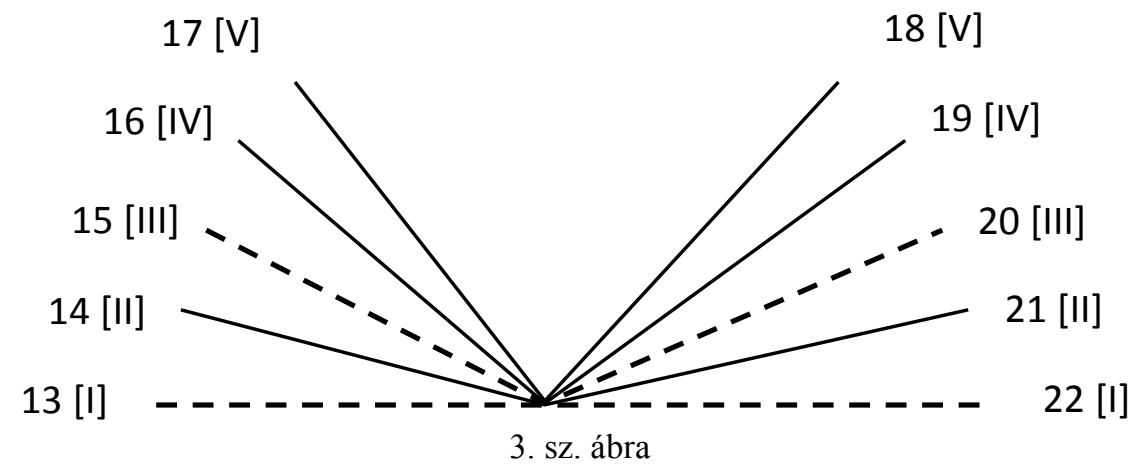

A tárgyalt versröl is elmondható, hogy egy olyan aposztrophikus szerkezettel kezdödik, mely mint felütés egyáltalán nem ritka régi költészetünk gyakorlatában sem.

1. Beborult, fölhözött, bánat hozó egem, Gyakor fázlalással mit borzasztál engem? Szomoritod kedvem, Venusnak tüzivel nem hagysz melegednem.

Az alapfikció tehát röviden úgy látszik összegezhetőnek, hogy aszerint az említett szerelmi kapcsolat valamiféle külső körülmény miatt nem teljesedhet be, s azért a beszélő mindenekelőtt az invokáció alanyát, vagyis az égboltot teszi felelőssé. Az epiplektikus alakzatból kiugró vád (accusatio) alapját a beszélő akadályoztatása képezi abban, hogy az

Szerelmes versek, a következö sorkezdetekkel [...] Ez az elsö [ti. a Maga lelke vigasztalásának négy énekecske c. ciklusból, az Örüll immár, lelkem... kezdetü. BP.] ének csonka, és a többi három hiányzik, mert utána egy levél kiesett és a 41. lapon megint csonkán kezdödik: Beborult folhozot bánat hozo egem, ami talán a negyedik ének vége. A füzetke önállóságát jezi, hogy a hátlapján (42. lap) különféle tollpróbák és jegyzések láthatók, s ez a szövegforditott írással: „Chokollia s niallia az niakan chugodik«, a középen pedig szintén fordítva: 》Generosi HADA«, ami arra mutat, hogy Madách eredetileg ebbe a füzetbe készült beirni Wesselényihez írt versét... RÖM, 163. „Ez a füzet is, mint a kódexbe kötött még néhány alakilag és tartalmilag is elkülönithetö levélcsomó, csonkán maradt ránk. Eredetileg legkevesebb nyolc levélböl állott, amiböl ma már csak öt van meg, az 1., 2. és az utolsó elötti 7. levél hiányzik. A füzet fedö, vagy elözéklapjaként odakötött, mindkét oldalán beíratlan tiszta levél (14. sz.) eredetileg nem tartozott a füzethez; csak a kötésnél ragasztották hozzá a hiányt jelölö, s közvetlenül utána következö ugyancsak tiszta levélhez (15. sz.). A füzetben 15 szerelmes vers található, egy kéztöl, egyféle tintával folyamatosan leirt másolatban. Az elsö »Ne gondold szerelmem « kezdetü vers az elején, a tizennegyedik »Örülj immár lelkem « kezdetü pedig a végén csonka. Ezen kivül a hiányzó 7 . levéllel bizonyosan kettö, az 1. és 2. levéllel pedig feltételezhetöen még további három vers pusztult el. Eredetileg tehát kb. 20 verset tartalmazott a füzet.” ВóTA, i. m., 1-2. (5. lábjegyzet.) „,Az I. kötet 1. füzete (3-22) Rimay-irásokat tartalmaz. A 2. füzet egyetlen üres levél (27-28). Eckhardt nem vette külön »füzetnek«, pedig elötte is, utána is 2-2 betétlevél áll. A 3. füzet (31-42) tartalma 15 szerelmes vers. A 38. lapon kezdödö a »Maga lelke vigaztalasanak 4 Enekeczke« címü versciklusból az elsö ének (Eörül Immar lelkem - 56. sz.) csonka. A második és a harmadik hiányzik. A negyediknek a befejezö strófái (Be borult folhozot banat hozó egem - 57. sz.) pedig a 39-40. lapszámozású betétlevél után a 41. lapon csonkán kezdődnek.” RMKT XVII/12, 663. 
Venus tüzéhez férkőzzék - értsd a testi szerelmet gyakorolja -, ez pedig kizárja, hogy az 'ég' jelölő alatt metonimikusan az egek Urát lehessen érteni.

Vagyis a tárgyalt vers profán hangütésü, noha az adott témakörben az ellenkezőjére inkább található szerencsés példa; így a diskurzusban legfőbb vonatkoztatási pontként tekintett Rimay-életműből elsősorban a Legyen jó idő csak... kezdetű poéma kívánkozik ide. Ebben ugyanis a költő - szintén kérdést formázó alakzatokon keresztül - az egzisztenciális összefüggésben értendő rossz időket (vö. 5. sor: „Hát miért ostoroz, s próbákkal miért sebhit?”) az adott képiségen belül maradva állítja jóra vezetőnek (vö. 9. sor: „Eső száraz földnek mit árt, ha meghinti? ’); hogy végre a magánbeszéd keretei között fejtse ki a ferendum et sperandum közkeletü gnómáját: ${ }^{438}$

5. No hát, én lelkem, türj, s tanulj reménleni,

Hogy tudhass Uradtúl sok jót érdemleni,

Mert mint köd után szép szokott az nap lenni,

Rajtad is búd után jód úgy fog fénleni.

Tematika és tipológia relációjához egyébiránt további fontos adalékot kínálnak az idézett Rimay-vers különböző kiadásait kísérő címfeliratok is. Az 1623-as unitárius énekeskönyvben afölött valamikor ez állhatott: „Metaphorica cantio”. ${ }^{439}$ A szöveget gondozó Ács Pál ezt példázat szerint való énekként fordítja, mivelhogy az legföképpen hasonlatokon keresztül tárgyazza a szenvedést és a világból való kimúlást, úgymint az imitatio Christi megvalósításának feltételeit. ${ }^{440}$ Az Istenes énekek bécsi edíciójának kapcsolódó argumentuma szerint a szerző „Ebben is könyörög Istennek, okát adván miért próbálja s sujtolja Isten az ö híveit. "441 A lőcsei pedig megint másként definiálja azt: „,Más. Lelki vigasztalás”. 442

E sokféle meghatározásról (példázat, könyörgés, vigasztalás) összességében az állapítható meg, hogy azoknak egyike sem illik igazán a Madách-Rimay-kódexek tárgyalt énekére. (Vélhetőleg ez is oka lehet, hogy a diskurzus során nagyobb összefüggésben nem vetődik fel a két vers rokoníthatóságának lehetősége.) Egyrészt az eleve homályos metaforikából alapvetően hiányzik a példázatosság. Másrészt jóllehet a vádolás a későbbiekben könyörgő tónusú rábeszélésbe (suasio) fordul majd, ámde ez által a beszélő csupán e kiüresített minőségében megszólított égboltnak tulajdonít valamiféle

\footnotetext{
${ }^{438}$ A soliloquium profán válfajára ld. példaként az előző éneket (Örüll immár, lelkem).

${ }^{439}$ Vö. RÖM, 198.

440 RJí, 300.

${ }^{441}$ Következnek gyarmati Balassa Bálintnak istenes éneki, Bécs, 1633, 13.

442 [Balassi Bálint, Rimay János Istenes éneki], Lőcse, 1666, 162.
} 
transzcendenciát. Harmadrészt a jó elérésében meggátolt beszélő a vigasztalásról is elég világiasan gondolkodik:

2. Irigyled-e annak várt boldogulását,

Szivemnek neveli ki vigasztalását?

Nézd hü ajánlását,

Vidulj meg, derülj fel, ne hervaszd orcáját!

A vigasztalás aktusa - emlékezzünk - előfordul a szóban forgó verssel azonos metrumú kilencedik ének (Oly nehéz nem látnom...) zárlatában is: abban a beszélő kívánja megvigasztalni hölgyét. ${ }^{443}$ De szerepet játszik az előző költemény (Örüll immár, lelkem...) utolsó fennmaradt szakaszában is, ám abban már - a fent idézett strófával egybehangzóan a harmadik személyben ábrázolt kedves mutatkozik cselekvő félként. ${ }^{444}$ Végső soron talán ez is okot adhatott arra, hogy a szemléletbeli különbség dacára Beborult, fölhözött... kezdetü éneket a kritikai kiadások a Maga lelke vigasztalásának 4 énekecske címet viselő versfüzér záró tételeként azonosítsák. ${ }^{445}$

Továbbmenve, a képhasználat ezen a ponton a virágmetaforák organikus trópusaival egészül ki, hogy aztán ezek a későbbiek során mind nagyobb játékteret nyerjenek:

3. Add látnom derülten kivántam személyét,

És ne epeszd bennem szivem reménségét,

Hadd foghassam kezét,

Ne zárd be utamot, s neki ne szegd kedvét!

A tizenegyedik sorban megjelenő kézfogás a vizsgált szerelmes énekek visszatérő motívuma. A megelőző helyeken egyszer sem mulasztottam el Jankovits László véleményének ismertetését, aki Rimay Ne csudáld szívemet... kezdetü költeménye alapján e kifejezést a házassági szándékra utaló kézfogó jelentésben magyarázza. ${ }^{446} \mathrm{~A}$ tárgyalt vers mondanivalójának tisztázása érdekében ezt most is indokoltnak látom megismételni; az ti. igen érdekesen alakul e legutóbbi fordulat következtében, melynek értelmében a beszélönek egyenesen a házassága múlik választottja boldogulásán, ami viszont - eleddig ugyan nem derült ki, miért - az időjárás szeszélyeinek van kiszolgáltatva.

\footnotetext{
${ }^{443}$ Ld. a vontakozó fejezetet.

${ }^{444}$ Ld. a vonatkozó fejezetet.

${ }^{445}$ Vö. a 437. lábjegyzetben foglaltakkal.

${ }^{446} \mathrm{Az}$ Oly nehéz nem látnom... és a Szerelmesitől vált... kezdetű énekek kapcsán, ld. a vonatkozó részfejezeteket. Vö. JANKOVITS, Soliloquium és oratio Rimay egy versében, 218.
} 
De többször idéztem Bóta László stilisztikai érdekü megfigyeléseit is arról, hogy a Beborult, fölhözött... kezdetű vers ez idáig közölt részében is kivehető alliterációk, ragozott igenevek és állítmányhalmozások a 17. század magyar nyelvű költészetének anyagából legnagyobb arányban Rimay lírai életmüvében mutathatók ki. ${ }^{447}$ És kitértem arra is, hogy Bóta a gyüjtemény mindkét Palkó-verséről (tehát a szóban forgó éneken kívül az imént már említett Oly nehéz nem látnom... kezdetűről is) úgy nyilatkozik, hogy azok „müvészi megformálásukkal Rimay ismert szerelmes verseit is túlszárnyalják.",448 Ezeket a megfontolásokat tehát minden esetben számításba vettem; most sem szeretnék azok fölött elsiklani.

A következő versszakban ugyanis az alapvetően botanikai képekből összeálló allegóriába egy másik locus communis ékelődik bele, mégpedig a tengerhajózásé. A kimondottan a tengeri viharral azonosított sorscsapások exempláris kidolgozása - mint arról szintén esett már szó ${ }^{449}$ - újfent csak megtalálható Rimay érvkészletében; hovatovább a kertmetaforikával elegyülve is. De még mielőtt összevetném a korábbiakban e kapcsán már citált ének (Ez világ mint egy kert...) és a tárgyalt vers argumentációs jellemzőit, érdemesnek látszik az alábbi, negyedik strófát előbb a trivium elemibb szintjei szerint, vagyis tkp. grammatikai szempontok alapján is megvizsgálni.

4. Látod az ö dolgát; úgy vagyon, mint nekem, Egymás nélkül veszély járnunk az tengeren, Habokkal hány engem, Segitsen ö nekem s én neki eveznem.

A fogalmazásbeli esetlenség egyfelől a szintaktikailag indokolatlan elliptikusságból és a mesterséges rendből származik, amennyiben a csapongó szerkesztésű mondategész utolsó előtti egységében nyelvileg nincsen jelölve, hogy e tagmondatnak ki vagy mi volna az alanya - amit a jelentés egyértelműsít ugyan, de azzal együtt mégis a barbarismus érzetét kelti. Másfelöl viszont az utolsó sorban óhajként elővezetett kölcsönösség tautologikus kifejezése egy, az előbbivel éppen ellenkező természetű nyelvi vétségként: szószaporításként ismerszik meg.

És mivel (úgy lehet ${ }^{450}$ ) a korabeli magyar irodalomelmélet egyik legfőbb poétikai zsinórmértéke a klasszikus retorika volt, melyhez minden versificator a maga tehetségéhez

\footnotetext{
${ }^{447}$ A Semmi állat nincsen..., az Egy szép rózsaszálat..., az Ércnél, kösziklánál... ill. a Szerelmesitől vált... kezdetü énekeket tárgyaló fejezetekben, ld. ott.

${ }^{448}$ Во́тA, i. m., 23. Ez ügyben ld. még az Oly nehéz nem látnom... kezdetü éneket tárgyaló fejezetet.

${ }^{449}$ Ld. a vonatkozó (Ki-ki terhét vállán ....) részfejezetet.

${ }^{450}$ Vö.: „,Az antik retorika csak egy müfajelméletet ismert, a beszédfajták elméletét.” Ács, Ratio és oratio, 275.
} 
mérten igazodhatott, akkor ezeket a vétségeket nem nagyon van okunk éppen a tudós Rimay János rovására elkönyvelni.

Visszatérve tehát a regisztrált toposzok együttállásának kérdésére: különös jelentőséget kölcsönöz ennek az a tény, hogy az Ez világ, mint egy kert... a tárgyalt verssel megegyezően szintén az agrokultúra és a tengeri közlekedés fogalomkörét alkalmazza az emberi kiszolgáltatottság allegorikus megjelenítésére, $\mathrm{s}$ azokban egyaránt a vihar tételeződik kulcsmetaforaként. A Beborult, fölhözött... esetében a gondolatmenet továbbra is ennek körüljárásával füződik tovább.

5. Fényes világoddal vidits meg bennünket,

Láthatod egymáshoz megindult kedvünket, Neveld örömünket,

Záportúl meg is ódd virágzó kertünket!

E sorok tükrében viszont az is elötünik, hogy a szerelmi tárgyú költészetben minduntalan számolni kell a frazeológia szexuális konnotációjával is - noha a versben érvényesülő tropika konzekvens szétszálazhatóságának illúziója (láttuk) még a felütésben szertefoszlott. A szerzői szándék ismeretének hiányában a befogadó e vélelmezett mögöttes jelentést pedig már csak azért sem tudja egyértelmüen megképezni, mert a szexualitás ábrázolhatóságának szabályaiból adódóan eleve nem mindig áll módjában különválasztani a metaforákat a betü szerint értendő szavaktól. Az olvashatóság felől nézve ez a szituáció legalábbis a Balassa János éneke sólymocskájárúl c. vers értelmezési dilemmáival rokon, melynek modern kori népszerüsége alkalmasint éppen ebből az apóriából fakad. E játék intencionáltságáról ugyanakkor végső soron semmiféle biztosítékkal nem rendelkezünk. Állítanunk ezért csak annyit lehet, hogy ha ez a technika tudatos, akkor az alkotásból egy, a nyelvi eszközöket magas szinten uraló parodia-szerző ismerszik meg - ám ha nem az, akkor mindez szimpla dilettantizmusból fakad.

A virágszimbolika szexuális töltésével e vers kapcsán - Nagy Ferenc kivételével ${ }^{451}$ - a korábbi szakirodalom mindenesetre egyáltalán nem számol, noha a szóelőfordulások analízise során Bóta László éppen az e tekintetben leginkább képlékeny kifejezéseket adatolja úgy, mint Rimay költői nyelvének jellegzetes elemeit. Az ötödik versszakban ilyen a zápor szó, melynek Balassi Bálint ill. Madách Gáspár írásaiban egyáltalán nincs nyoma, ezzel szemben a Rimay-életmüben háromszor ismétlődik meg: két istenes énekében (Minden dolgok között

${ }^{451}$ Vö. NAGY, i. m., 34-37. 
láthatsz viszáltatást...; ${ }^{452}$ Mennyekben lakozó imádandó fölség... $\left.{ }^{453}\right)$ és egy gyászversében $(A z$ Úr engem sanyarita... ${ }^{454}$ ) is. Ezek közül az utóbbi, kisfia, Rimay Jánoska elvesztésének fájdalmában fogant, megindító szerzeménye ráadásul - melynek közlésétől itt pusztán terjedelmi okok miatt tekintek el - a Beborult, fölhözött... kezdetü énekéhez sok szempontból igen hasonló toposzból bomlik ki, aminek következtében döbbenetesen erős tematikai kontrasztot képez azzal. Ámde sajnos akármennyire érdekes kérdéseket vet is föl mindez, gyakorlatilag beláthatatlan, hogy e két alkotás mennyiben gyakorolhatott hatást egymásra.

Szembeötlő ugyanakkor az is, hogy a következő versszak rímbokrának virtuozitása mint költői teljesítmény ismét csak Rimay János iskoláját idézi: ${ }^{455}$

6. Illetünk téged is belöle jó szaggal,

Az mi szerelmünket ne terheld haraggal,

Te birsz minden maggal,

Kémélyve bánj velem, mint szerelmes rabbal!

A szag-harag-mag-rab konstellációból Bóta ráadásul az első és a harmadik tagot mint önmagában is Rimayra jellemző motívumot említi. Előbbiről (szag) az Egy szép rózsaszálat... kezdetű ének tárgyalása örvén esett már szó, ${ }^{456}$ gyakorlatilag ez utóbbi (mag) is ahhoz hasonló gyakoriságban fordul elő a Rimay-versanyagban. ${ }^{457}$ Mindazonáltal a hiteles Rimayversek és a vizsgált korpusz viszonyát tovább bonyolítja, hogy noha az Encomia et effecta virtutum c. költeményben (Itt egy asztalt látunk...) történetesen mindkét kifejezést felhasználja a költő, utóbbit ( $m a g$ ) kétszer is ${ }^{458}$ - s noha ott azokat nem helyezi a mintegy elkölcsönzésért kiáltó rímpozícióba egymással, az előbbi (szag) közvetlen kontextusa megint csak feltűnő egyezéseket mutat a Beborult, felhőzött... kezdetü ének képi világával.

1. Itt egy asztalt látunk körül telepedve, Akire szép himes abrosz vagyon vetve, Virágos gyümölcsfák nönek fel mellette, Csorgó kút is látszik kert felöl mellette.

\footnotetext{
${ }^{452}$ „Zápor nagy hegyeket, szél nagy tökéket ont”. (RÖM, 26. sz., 6. sor.)

453 „Mit mondjak? vétkem sok, mint föveny, szapora, / [...] / De oszlatja, mossa kegyelmed zápora”. (RÖM, 20. sz. 13-15. sorok.)

${ }_{454}^{45}$,Amely kertet sem dér, ragya, / Zápor s köesö sem járja”. (RÖM, 67. sz., 9-10. sorok.)

${ }^{455}$ Vö. BóTA, i. m., 22.

${ }^{456} \mathrm{Ld}$. a vonatkozó fejezetet.

${ }^{457}$ Nem lehet szebb dolog az keresztyénségnél... (RÖM, 23. sz.), 15-16. sorok: „Bár csak Ábrahámnak példájára tekints, / S hasznos magot onnan lelked kertében hints"; Könyörülj énrajtam, Úristen, s irgalmazz... (RÖM, 41. sz.), 19-20. sorok: „Elsö téjjel együtt az bünt szoptam, nyaltam, / Onnan való magból bünre így ágaztam”; Az idö ósága nevel magas fákot (RÖM, 68. sz.), 2-3. sorok: „, Mint tél után nyár hoz kórókra virágot, I Így koporsó terjeszt hírnek, névnek magot."

${ }^{458}$ RÖM, 64. „,Hü szeretetinek hintegeti magvát, / Szoritván mellyéhez szoptató magzatját.” (43-44. sorok) „,Ója igen magát, ne terjedjen magva / S fertelmének hire ne folyjon áradva." (107-108. sorok).
} 
2. Ez helt ékesiti árnik és csendeszség,

Nem éri az asztalt sem szél, sem nap-hévség,

Sok virág asztalon, szagjok gyönyörüség,

Fölhövel sem burul ez hely fölött az ég.

A hatodik versszakban mindamellett a korábban deszakralizált megszólított (vagyis az ég) reszakralizációja is megfigyelhető, melynek során a beszélő áldozatot kínál annak (21. sor), féli a haragját (22. sor), elismeri hatalmát ill. potenciáját (23. sor), valamint - a fennforgó ügyben nem annyira kézenfekvő módon - számít együttérző reakciójára (24.). Ez utóbbi kitétel annál is különösebb, hiszen a szerelmi rabságból mint állapotból (conditio) vett érv az udvarló költészetben általában a hölgy belátására apellál, ezért is szokás rendszerint neki címezni. A szerepek ötletszerü újraosztásából adódóan viszont a továbbra is lebegtetett szexuálmetaforika egyre nehezebben értelmezhető; ahhoz a következő strófa esetében, melyben a beszélő egyenesen a kedvesét invokálja, valamiféle zavart kell feltételeznünk az identitásában: ${ }^{459}$

7. Te is, személyemben örvendö szerelmem, Szerelmedben ne hagyj üresültnek lennem, Megnyugodjál bennem, Restségben nem találsz, ha szolgáltatsz velem.

Joggal vetődhet fel ezért a kérdés: ez esetben van-e szükség egyáltalán a testiség - némely mozzanatában tehát védhetetlenül inkoherens - allegóriájának bármiféle jelentőséget tulajdonítani? Nos, a záróstrófa végképp arról győzi meg az olvasót, hogy a vers értelmezési tartományában e megközelítésnek minden kétséget kizáróan mégiscsak van némi relevanciája:

8. Sokféle szerencséd ne lehessen, csak egy,

Búval, bánattal is soha ne ismerkedj,

Épen álljon a hegy,

Melyet szám izihez terem szép piros meggy.

Ugyanis ha ezt a szakaszt (a többivel együtt) sensus litteralis közelítjük meg, a versszöveg líraiságát tesszük kockára; mégpedig a következők miatt.

Sokat idézett dolgozatában Bóta László jobbára tartózkodik az egyes költemények exegézisétől. A tárgyalt vers mondanivalóját azonban egy mondat erejéig mégiscsak összegzi. Eszerint „a költö isten helyett a borongós természetet, a kedvezötlen időjárást engeszteli,

\footnotetext{
${ }^{459}$ Az 'üresült' kifejezést Balassi nem használja, ám a Rimay-életmüben két helyen is elöfordul. Vö. Örök életnek... (RÖM, 46. sz.), 52-54. sorok: „De Publicanus / Üresült keble / Véle béven telhet”; ill. Ez világ mint egy kert..., (RÖM, 30. sz.), 3. sor: „,O mint romlandó ház, elveszendő szállás, jóktúl üresült rekesz.”
} 
hogy viduljon, derüljön ki, hogy ö mielöbb kedveséhez utazhasson. "460 Igazság szerint az utazás motívuma ugyan több helyütt is előfordul a gyüjteményben, ám ennek általános érvényű kiterjesztése a füzet minden darabjára, így Beborult, fölhözött... kezdetü énekre is, csak közvetetten felel meg az interpretáció deiktikus maximájának. ${ }^{461}$ Amire vélhetőleg azért volt szükség, mert azon keresztül továbbfejleszthető az a hipotetikus elképzelés, miszerint a vizsgált anyag egyetlen szerzőtől (Rimay Jánostól) származik: méghozzá akképpen, hogy az teljes egészében a költő egy adott élethelyzetében keletkezett. ${ }^{462}$

Ezúttal nem kívánom a fenti koncepció érvényességét feszegetni. Mindezt csupán annak szemléltetésére referáltam, hogy a mü e világszerü, s ezért szükségképpen naiv olvasata sem foglalja magában azt a lehetséges jelentésréteget, hogy az amúgy ígéretes frigy létrejötte éppen egy gyümölcsöskert terméshozamának lenne függvénye. Vagyis e rímszavak metaforikusan értendők, és a testi kívánságok (vö. Venus tüze) kifejezéséhez szolgálnak csattanóként - igen jellemző, hogy azok konkrét mibenléte voltaképpen sehogyan sem látszik megállapíthatónak. ${ }^{463}$

Végezetül mégis ehhez szeretnék egy olyan lehetséges megoldási javaslatot kínálni, amelynek értelmében a kérdéses szöveghely az illendőség határai közt marad. A rímek forrását elsőként szintén Bóta mutatja ki Balassi kilencedik Célia-versének második versszakában. A Julia szózatját, kerek ábrázatját... kezdetủ ének alapkonfliktusának, mint tudjuk, az a lényege, hogy a beszélőben újabb szerelme, Célia jelenléte a régi szerető, Júlia fájdalmas emlékét idézi meg, lévén e két hölgy egyes tulajdonságaiban nagyfokú hasonlóságot mutat:

2. Egyenlö két rózsa, kinek mind pirosa, állapatja, színe egy,

Sem egy ágon termett, ki zöld levél fedett, nem hasonlóbb két ért meggy,

Mint ez Juliához, kinek szép voltához gerjedek, mint Aetna-hegy.

Szilasi László figyelt föl arra, hogy a fenti részletben „a hasonlóságot érzékeltetni kivánó alakzatok mögött árnyékszerü metonimikus viszonyok kezdenek feltünedezni”," $464 \mathrm{~s}$ ez a meggyeket illetően nemcsak az általa kiemelt lokális érintkezésben ragadható meg, de a

\footnotetext{
${ }^{460}$ BÓTA, i. m., 12.

${ }^{461} \mathrm{Az}$ interpretációs maximák fogalmához ld.: ODORICS Ferenc, Interpretációs maximák, Irodalomtörténet, $1993,547$.

${ }^{462}$ Ez a korábban (az Ércél, kösziklánál... kezdetü énekröl írott fejezetben) már idézett kiindulópont a következő: „A $M-R$ kódex szerelmes énekei is egy ilyen kedvesétöl távol élö boldog szerelmes érzéseiböl fakadnak. A távolság, a különlét emlegetése visszatérö motívum ezekben a versekben, ami nem egy alkalomszerü, de huzamosabb szétszakitottságra enged következtetni." BóTA, i. m., 11.

${ }^{463}$ A hegy szót 'halom' v. 'rakás' értelemben a Történeti-Etimológiai Szótár legkorábban Petőfi költészetéből adatolja, vö. TESz, II, 82-83.

${ }^{464}$ SZILASI, A sas és az apró madarak, 174.
} 
Balassi-versanyag tágabb kontextusát tekintve a szinekdoché trópusában is. E rímszavak ti. jórészt már korábban, a Hatodik c., Bebek Judit nevére szerzett versben (Beteges lelkem ismét...) is megjelennek:

4. Erkölcse szelíd és szemérmetes, emberséggel elegy,

Édes ajaka piros, szinte oly, mint jól meg nem ért meggy,

Ékes beszédü, jeles tréfájú, szavában ö mind egy.

A meggy tehát azért lehet a hölgyek metaforája, mert - mint előzőleg bebizonyosodott színében és ízében is nagyon hasonlít azok egy bizonyos részére: az ajkaira. Mivel pedig a tárgyalt versben is emlegetett szerelmi szolgálat fizetsége a csók, elképzelhetőnek tartom, hogy a nehezen értelmezhető zárlat is erre kíván utalni. ${ }^{465} \mathrm{~A}$ minta precíz argumentációját mindamellett teljes egészében elhagyja. Bóta az üst-füst-ezüst rímszavak továbbhagyományozódásának analógiájára felteszi, hogy ehelyütt is az érdemes tanítvány Rimay igyekezett a toposz rangjára emelni mesterének e tetszetős rímbokrát. ${ }^{466} \mathrm{~A}$ Beborult, fölhözött... kezdetü ének záróformulája azonban nemcsak retorikai teljesítményében marad el messze a hiteles Rimay-verseket jellemző igényességtől, de az sem látszik túlságosan valószerünek, hogy az eredetileg meglehetősen visszafogott erotikájú Balassi-sorokat éppen Rimay János mozdította volna el egy nehezen átlátható, s ezzel együtt az obszcenitás felé is szélesen nyitott szemantikai mező irányába. ${ }^{467}$

\section{Összefoglalás}

A vizsgált anyag tizenötödik, záró darabja, a Beborult, fölhözött, bánat hozó egem... kezdősorú ének a Palkó-vers ritmus- és rímképletét követi. A versforma megjelenése nem egyedülálló a gyüjteményben; a kilencedik tétel (Oly nehéz nem látnom ...) szintén aszerint íródott. Föltünik, hogy amellett e költemények invenciója is sokban egyezik - ám ennek aligha tulajdoníthatunk különösebb jelentőséget, hiszen ezek a mozzanatok (kényszerü távollét, epekedés, a viszontlátás reménye, stb.) a füzet más, felező tizenkettesekben ill. Balassi-strófában szerzett énekeiben is több ízben előfordulnak. ${ }^{468}$

\footnotetext{
${ }^{465}$ Vö. KISS, i. m., 310.

${ }^{466}$ Vö. BÓTA, i. m., 22.

${ }^{467}$ A kérdésről bővebben ld. az ötödik énekről (Szerelemtül csak kár...) írott részfejezetet.

${ }^{468}$ Gondolok itt elsősorban az Oly nehéz nem látnom..., az Ércnél, kösziklánál..., a Szerelmesitöl vált... és az Én édes jobb kezem... kezdetü énekekre, ld. a vonatkozó részfejezeteket.
} 
A formaiság egy további szempontját, a vers terjedelmét szemügyre véve viszont már valamivel megragadhatóbb összetartozás rajzolódik ki a korpusz belsejében, méghozzá ezúttal e nyolcszakasznyi záró-, valamint a kilencstrófás nyitóvers (Ne gondold, szerelmem...) között. Ez az önmagában még a metrikai jellemzőknél is esetlegesebb tulajdonság ugyanis a következő megfigyeléssel egészíthető ki: a tizenöt éneket tekintve a Ne gondold, szerelmem... és a Beborult, fölhözött... kezdetü szerzeményekre egyként és kizárólagosan igaz, hogy szerencsekívánó záró strófájuk egy szótagos Balassi-rímszavakból (nap-kap-rab ill. egy-hegymeggy) építkezik.

Annál is érdekesebb kitérni azok tartalmi különbségeire is. Egyrészt a lírai alaphelyzetük sem ugyanaz. Az előbbi még egy az udvarlás fázisában járó szerelmest mutat, az utóbbiét viszont már csak valamely kellemetlen circumstantia gátolja meg a szerelmi kapcsolat (alkalmasint hivatalos) beteljesítésében. Másrészt pedig - talán éppen emiatt - e két vers igen eltérő argumentatív toposzkészletből gazdálkodik. A füzet első énekének szerzője célja eléréséhez javarészt alászálló petrarkista sablonokat alkalmaz, mint láttuk, körültekintő szolidsággal. ${ }^{469} \mathrm{Az}$ utolsóé ezzel szemben olyan közhelyeket használ fel, melyek Balassi Bálint v. Rimay János költészetétől idegennek szintúgy nem mondhatók, csakhogy azon belül ezek a tárgyalt versnél jóval kidolgozottabb, vagyis irányított összefüggésekben fordulnak elő, gyakran nem is szerelmi témakörben. Az elődszövegek e gyakorlatának felfüggesztése ill. figyelmen kívül hagyása eredményezi tehát a Beborult, fölhözött... kezdetü ének legmarkánsabb attribútumát, mely utóvégre egy retorikai vétség, az ambiguitas minduntalan zavarba ejtő alakzatában ragadható meg.

${ }^{469}$ Ld. a Ne gondold, szerelmem ... kezdetü versröl írott fejezetet. 
KONKLÚZIÓ 


\section{Jég, kása, hegy}

Még mielőtt nekifognék megválaszolni a dolgozat előszavában feltett kérdéseket, szükségét érzem visszatérni Szilasi László korábbi számvetéséhez. A trópus-funkciótörténeti érdeklődésű, s mint ilyen, a maga nemében alapvető $A$ sas és az apró madarak c. monográfiájának retrospektív előszavában egy helyütt Szilasi a munkája során felmerült metodikai problémákat katalogizálja, s azok közül első helyen az alábbiakat említi: „,Az imitációs kapcsolatról hamar kiderült, hogy a szó igazán szoros értelmében sohasem bizonyitható. Két szöveg hasonlósága vagy szignifikáns eltérése a kontakt hatáson kivül számos más tényezővel is magyarázható. Az imitációs kapcsolat a legsúlyosabb textológiai, filológiai érvek után sem mutatkozhat másnak, mint fikciónak, hipotézisnek, a narratíva és az emlékezet legalapvetőbb trópusának. ",770

Noha teljes mérték egyetértek ezekkel a számomra nagyon inspiratív sorokkal, jómagam mégiscsak arra tettem kísérletet, hogy a Madách-Rimay-kódexek tizenöt szerelmes versének imitációs technikájára irányuló vizsgálódásaim során leginkább a valószínüségen alapuló következtetésekre szorítkozzak - még akkor is, ha ezzel alighanem végérvényesen szem elől tévesztettem egy hajszálfinom összefüggésrendszer jelentős részét. Ez alighanem a legközhelyesebb dilemma a régi magyar költészet történetének kutatásában; ti. hogy tehetünke érvényes állításokat a jéghegy egészéről, ha csupán annak a csúcsát vagyunk képesek vizsgálni. Sietve szögezném le: én ezúttal mindössze a jéghegy csúcsáról kívántam állításokat tenni.

Jelen dolgozatomban tehát elsősorban az okkal feltételezhető, textológiai és filológiai érvekkel alátámasztható kontakthatást tekintettem olyan legitimációs alapnak, amely megengedi az elöbbiekben közölt értelmezéseket. Ezek létrehozása során a figyelmem elsősorban bizonyos jól körülhatárolható értékek együttállására irányult; tkp. az így kialakított mintázatokra hagyatkozva kerestem a választ a kérdéseimre. És csak utólag ébredtem rá nem mintha egyébként meglepő volna -, hogy gyakorlatilag a 17. századi vers készülöben

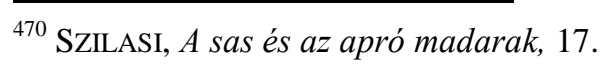


lévő repertóriumának teljes szerkezetét átfogó (ahhoz mérten természetesen nagyon elnagyolt és túlegyszerüsített) szempontrendszert sikerült kialakítanom. ${ }^{471}$

Mindezt az alábbi táblázat segítségével tudnám szemléltetni:

\begin{tabular}{|c|c|c|c|c|c|}
\hline $\begin{array}{c}\text { Sor- } \\
\text { Szám }\end{array}$ & Incipit & $\begin{array}{c}\text { Vsz. } \\
\text { szám }\end{array}$ & Versforma & Funkció & Típus \\
\hline 1. & Ne gondold, szerelmem... & 9 & felező 12-es & levél & udvarló \\
\hline 2. & Nagy példát adhatok... & 3 & felező 12-es & & didaktikus-moralizáló \\
\hline 3. & Ki-ki terhét vállán... & 4 & felező 12-es & & didaktikus-moralizáló \\
\hline 4. & Bírja bár akárki... & 4 & felezö 12-es & & udvarló \\
\hline 5. & Szerelemtül csak kár... & 4 & felező 12-es & & didaktikus; paródia \\
\hline 6. & Semmi állat nincsen... & 5 & felező 12-es & & udvarló \\
\hline 7. & Egy szép rózsaszálat... & 3 & felező 12-es & (kísérö)levél & udvarló \\
\hline 8. & Látod ez gyöngyszemet... & 4 & felező 12-es & (kísérö)levél & udvarló \\
\hline 9. & Oly nehéz nem látnom... & 4 & Palkó-vers & & magánbeszéd \\
\hline 10. & Hárfa ... at valahova... & 4 & 3 soros Balassi-strófa & & didaktikus-moralizáló \\
\hline 11. & Ércnél, kösziklánál... & 3 & 9 soros Balassi-strófa & (válasz)levél & udvarló \\
\hline 12. & Szerelmesitöl vált... & 3 & 9 soros Balassi-strófa & (válasz)levél & udvarló \\
\hline 13. & Én édes jobb kezem... & 3 & 9 soros Balassi-strófa & (válasz)levél & udvarló \\
\hline 14. & Örüll, édes lelkem... & $x(\geq 6)$ & felező 12-es & & magánbeszéd \\
\hline 15. & Beborult, fölhözött... & 8 & Palkó-vers & & udvarló \\
\hline
\end{tabular}

\begin{tabular}{|l|l|l|}
\hline $\begin{array}{c}\text { Sor- } \\
\text { szám }\end{array}$ & \multicolumn{1}{|c|}{ Beszédnemek } & \multicolumn{1}{|c|}{ Szövegszervező trópusok } \\
\hline 1. & defensio; suasio; dissuasio; laus & aposztrophé; metafora \\
\hline 2. & accusatio; dissuasio; vituperatio & aposztrophé; hasonlat; metafora; példa \\
\hline 3. & laus; vituperatio & metafora; példa \\
\hline 4. & suasio; dissuasio; laus & hasonlat; metafora \\
\hline 5. & suasio; dissuasio; laus; vituperatio & alliteráció, metafora, oxymoron; irónia \\
\hline 6. & suasio; dissuasio; laus; vituperatio & alliteráció; aposztrophé; metafora \\
\hline 7. & suasio; laus & alliteráció; aposztrophé; hasonlat; metafora; metonímia; halmozás \\
\hline 8. & suasio; dissuasio; laus; vituperatio & aposztrophé; hasonlat \\
\hline 9. & laus; vituperatio & alliteráció; humilis díszítettlenség; halmozás \\
\hline 10. & suasio; laus; vituperatio & aposztrophé; hasonlat; metafora; példa \\
\hline 11. & suasio; vituperatio & aposztrophé; hasonlat; szentencia \\
\hline 12. & suasio; vituperatio & aposztrophé; hüpolépszisz; halmozás \\
\hline 13. & suasio; laus & aposztrophé; szinekdoché \\
\hline 14. & suasio; laus & aposztrophé; personificatio; allegória \\
\hline 15. & suasio; dissuasio; laus; vituperatio & aposztrophé; personificatio; allegória; halmozás \\
\hline
\end{tabular}

\begin{tabular}{|l|l|l|l|}
\hline $\begin{array}{c}\text { Sor- } \\
\text { szám }\end{array}$ & \multicolumn{1}{|c|}{ Toposzok } & \multicolumn{1}{c|}{ Reminiszcenciák } & \\
\hline 1. & & & BÖM, 83. sz., 2. vsz. \\
\hline 2. & & BÖM, 73. sz., 9. vsz. & \\
\hline 3. & & & RÖM, 57. sz., 3.; 64. sz., 30. vsz \\
\hline 4. & & RÖM, 64. sz., 47. vsz. & BÖM, 86. sz., 4. vsz. \\
\hline 5. & & & BÖM, 83. sz., 2. vsz. \\
\hline 6. & & & \\
\hline 7. & & & \\
\hline 8. & & & \\
\hline 9. & távollét & & \\
\hline
\end{tabular}

${ }^{471}$ Vö. BALÁZs-HAJdu Péter, BognÁR Péter, HeVesi Andrea, SinKA Zsófia, Szegedi kísérlet a 17. századi magyar vers gépi feldolgozására = Filológia és textológia a régi magyar irodalomban, szerk. KECSKEMÉTI Gábor, TASI Réka, Miskolc, ME BTK Magyar Nyelv és Irodalomtudományi Intézet, 2012, 461-470. 


\begin{tabular}{|l|l|l|l|}
\hline 10. & & & \\
\hline 11. & távollét & & \\
\hline 12. & távollét & BÖM, 83. sz., 3. vsz. & \\
\hline 13. & távollét & & \\
\hline 14. & & & \\
\hline 15. & & & BÖM, 78. sz., 2. vsz. \\
\hline
\end{tabular}

Jobban meggondolva ugyanis az olvasatokban szem előtt tartott versforma és -terjedelem az adatbázis verstani részterületének, az énekek típusa ill. funkciója a müfajiságot leíró konnotációs táblázatának, a reminiszcenciák a textológiai fejezetének, a beszédnemek, a domináns trópusok és a toposzok pedig az irodalomelméleti vonatkozású reflexiókat kategorizáló qualitas-blokkjának érdekkörébe tartoznak. ${ }^{472}$

\section{A terjedelem}

A füzet verseinek egyik legszembetűnőbb formai jegye a rövidség. A legrövidebbek mindössze három versszakot tesznek ki, de a leghosszabb sem számol többet kilencnél - ez átlagosan 4,5 strófányi terjedelmet jelent. Rimay János szerelmes énekei több mint másfélszer ilyen hosszúak $(7,2)$, Balassi Bálint esetében pedig ez a szorzó majdnem kétszeres: a középarány 8,8 versszak. ${ }^{473}$ Ugyanakkor a Balassi-kutatók régi megfigyelése értelmében, miszerint a Balassa-kódex egyes tömbjeinek versanyaga (a házasságáig szerzett versek, a házassága után szerzett versek ill. a Célia-ciklus) szerkezetileg igen eltérő jellemzőkkel bír, érdemesnek láttam ez alapján a részeredményeket is kiszámítani. ${ }^{474}$ Eszerint az első blokk tartalmának 10,6, a másodikénak 8,9, míg a harmadikénak csak 5 a strófaátlaga.

Az első konzekvencia, amit ebből máris levonhatunk: a terjedelem tekintetében ezek a versek az általunk ismert Rimay János gyakorlatánál inkább a kései Balassiéhoz állnak közelebb. Ezt tovább erősíti a tény, hogy e két elödköltő közül háromstrófás szerelmes verseket a mai tudásunk szerint eleve csak Balassi Bálint írt: a legrövidebb ilyen témájú vers, ami Rimaytól ránk maradt, 4 versszak terjedelmü.

\section{A versforma}

\footnotetext{
${ }^{472} \mathrm{Az}$ idézett dolgozatban toposzokról nem esik szó. Miután azonban a retorikai jellemzőket általánan a konnotációs tábla öleli fel, bátorkodtam az újabb kihívásként jelentkező toposzkutatást is ennek az egységnek alárendelni (vö. Heinrich LAUSBERG, Handbuch der literarischen Rhetorik, München, Max Hueber, 1960, §§ 400-409.).

${ }^{473} \mathrm{Az}$ eltérő tematika okán a Balassa-kódex következő énekeit hagytam figyelmen kívül: Áldott szép pünkösdnek..., Áldj meg, minket, Úristen..., Bocsásd meg Úristen ..., Vitézek, mi lehet.

${ }^{474}$ KlanicZAY Tibor, A szerelem költöje = K. T., Reneszánsz és barokk: Tanulmányok a régi magyar irodalomról, Bp., Szépirodalmi, 1961, 274.
} 
A tizenöt szerelmes ének ritmus- és rímképlete alapvetően három strófaformát követ: azok közül kilenc felező tizenkettesben, kettő a Palkó-vers, négy pedig a Balassi-strófa szabályai szerint íródott. Fontos észrevenni azonban, hogy a vizsgált korpuszban a Balassi-strófa kétféle tördelési módja is megjelenik: az egyik a versszak névadója által kialakított három-, a másik a későbbi fejleményként ismert kilencsoros változat. Jelen pillanatban ugyanis ez az egyetlen textológiai érvünk amellett, hogy a füzet versanyaga esetlegesen nem egyetlen szerzőtől való, lévén a Hárfa ...at valahova juthat... kezdetü ének az elöbbi, a rákövetkező három verses válaszlevél viszont egyként az utóbbi lejegyzési módot tükrözi. A számot tovább pontosítani, és főleg a szerzők személyét meghatározni a fentiek alapján nem lehet.

A terjedelem és a versforma összefüggései kevéssé jelentőségteljesek. Azokról mindösszesen annyi mondható el, hogy míg a felező tizenkettesben és a Palkó-vers mintájára kelt énekek viszonylag tág, addig a Balassi-strófában szerzettek csak szükebb keretek között mozognak: az előbbiek, láttuk, 3-9 ill. 4-8 versszaknyi terjedelemre kalibráltak, addig az utóbbiak mindössze 3-4 strófa közé esnek.

\section{A verstipus}

A kora újkori magyar költészet müfaji rendszere a legújabb kutatások szerint mindössze két osztályból tevődik össze: az egyik a históriáké, melyekben a szerzői fikció egyáltalán nem kap teret, a másik pedig az énekeké, melyekre az előbbi megszorítás nem érvényes. ${ }^{475}$ Ennek a meglehetősen rigorózus álláspontnak a megalapozottságát az is mutatja, hogy a költészettörténeti diszkurzusban mindig is szokás volt eltérő (közvetlenül össze nem egyeztethető) megközelítésekkel kialakítani egyfajta deskriptív tipológiát, amelyben az egyes részhalmazok nem bizonyos egzakt műfaji előírások betartása révén szerveződnek, hanem egyéb, leggyakrabban praktikus megfelelések apropóján.

Ennek megfelelően vezette be a korszak versanyagának totális kiértékelésére vállalkozó (de szerényen csak RPHA 17 néven emlegetett) adatbázis az ún. konnotációs tábla, valamint a qualitas-blokk fogalmát ill. intézményét. Tette mindezt arra az előfeltevésre hagyatkozva, hogy ha szigorú értelemben vett müfaji rendszereknek a versanyag nem is feleltethető meg, valamiféle poétikailag releváns tendenciák mégiscsak tetten érhetők abban. A két részterület között az a különbség, hogy míg a konnotációs tábla összeállítói elvileg

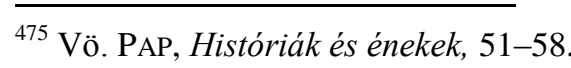


szabadon választhatják meg azokat a kategóriákat, melyek a gyanítható korrespondanciák feltárásához vezethetnek, addig qualitas-blokk készítői a versszövegekben és azok paratextusaiban explicite megjelenő irodalomelméleti vonatkozású kifejezéseket gyüjtik össze. $^{476}$

Miután a Madách-Rimay-kódexek szerelmes versei mindezidáig nem kerültek ilyesformán feldolgozásra, az érdekesség kedvéért most magam vállalkoznék azok besorolására. A mutatványban csakis régóta bevett szempontok alkalmazására törekszem. Ezek szerint a vizsgált énekek köztudottan szerelmi tárgyúak, a beszélőjük kivétel nélkül férfi. ${ }^{477} \mathrm{~A}$ legnagyobb vonalú megoszlás talán a hangütésükben érzékelhető: noha zömmel udvarló szerzemények, van köztük néhány didaktikus és/vagy moralizáló típusú is, ámde azokból az egyik (Szerelemtül csak kár...) valójában egy vaskosan parodisztikus (latrikánus) ellendarab.

A legáltalánosabb tulajdonság tehát, amit ennek tükrében szóvá tehetünk a füzet anyagáról, hogy az a verstípusok tekintetében nem teljesen homogén. Ez azt is jelenti, hogy nem pusztán mintaköltemények gyanánt másolták egybe az egyes tételeket. A vizsgált korpusz mérsékelt reprezentativitása nemigen kedvez a határozott kijelentések alátámaszthatóságának, de talán az sem teljesen a véletlen müve, hogy a kilenc sorra tagolt Balassi-strófában szerzett írások kivétel nélkül udvarló versek; típusbeli megoszlás tehát csak a többi ének között mutatható ki. Az iménti állítás a következő észrevétel nyomán pontosítható. Ha a didaktikus hangvétele okán elhagyott, három sorra tagolt Balassi-strófában keletkezett Hárfa ...at valahova... kezdetü verset összevetjük a további két moralizáló, de felező tizenkettesben írott szerzeménnyel, beláthatjuk, hogy az előbbiből hiányzik a személyes érintettség, mely a másik kettőben ráadásul egyként a csalódottságban ragadható meg. Vagyis a gyüjtemény e formájukban is a nagy elődöt idéző versei közül ha van is olyan, ami nem direkt udvarló-bókoló természetű, az sem tanácsolja el a testi szerelem megélésétől az olvasóját.

Ezekkel az alosztályokkal viszont nem tartom célravezetőnek kiegészíteni az általam javasolt kategóriát. A mértéktartás egyik oka, hogy a tizenöt ének óvatos becslések szerint is csak 0,0065\%-a a teljes feldolgozandó anyagnak, ezért félö, hogy a finomhangolás a munka végére érve esetleg túlaprózná a kinyerhető részhalmazokat. De van itt még valami.

\footnotetext{
${ }^{476}$ BALÁZs-HAJdu, BognÁR, Hevesi, SinKa, i. m., 465-470.

${ }^{477}$ Az állításom második felének ellentmondó szöveghelyeket (jellemzően a Semmi állat nincsen ..., az Oly nehéz nem látnom... és a Beborult, fölhözött... kezdetü versek esetében) az elemzések során ált. valamiféle retorikai sutaság eredményeként magyaráztam; bár ennek helytállóságában nem lehettem maradéktalanul biztos. A megelőző dilemmákról ld. a vonatkozó részfejezeteket.
} 
Adatbázisban keresni jobbára ún. kemény adatok alapján lehet. Ez a szakzsargonban azt jelenti, hogy az egyes rekordok leírásakor szükségképpen figyelmen kívül kell hagyni az akcidenciális tényezőket. Ebből adódóan a kemény adatok valamennyire bizony torzítanak. Ezért kell törekedni az adatmodellek kategóriáinak minimalizálására. A repertóriumon végigfuttatott keresésekből kapott eredmények, a „releváns belső korpuszok” (C Szilasi) jelentősége amúgy is éppen az volna, hogy az egésszel szembeni tehetetlenség helyett az értelmező végre esélyt kap személyesen nekiszegezni a deficit nélkül nem strukturálható, merthogy nagyon képlékeny, és ettől igazán lényeges kérdéseit a kutatni vágyott irodalmi szövegeknek.

\section{A funkció}

A vizsgált gyüjtemény a hasonló tematikájú füzérekhez v. kolligátumokhoz mérten kirívóan nagy arányban tartalmaz szerelmeslevélként funkcionáló alkotásokat. Még mielött rátérnék ennek analízisére, megpróbálom tisztázni, hogy a tervezett adatbázis mely részterülete illetékes kezelni ezt a minőséget. A sorrendben az első, Ne gondold, szerelmem... kezdetü ének ilyetén rendeltetéséről csupán egy funkciót determináló formula árulkodik, melyet egyébként német humanista minták alapján nemrégiben Bognár Péter azonosított a korabeli magyar nyelvű versanyagban: eszerint a vers záróstrófájában olvasható jókívánság alapmotívuma ( $x$ időegység plusz még többször $x$ időegység) a 15. századi német nyelvü üdvözlőversekből származik, tehát értelmét mint levélzárlat nyeri el. A tizenöt versike között azonban másfajta levelek is akadnak. Az egyik további alcsoportba így az Egy szép rózsaszálat... és a Látod ez gyöngyszemet... kezdetű énekek tartoznak. Ezek szintén misszilisként definiálják magukat azáltal, hogy virág- v. ékszerküldeményt írnak le és vonatkoztatnak egy adott (aktuális) helyzetre. Ezeket az előzőekben vázolt immanens tulajdonságokat pedig nyilvánvalóan a konnotációs tábla referenseinek kell láthatóvá tennie. Igen ám, csakhogy a harmadik részhalmaz elemei, az udvarló válaszlevelek (Ércnél, kösziklánál..., Szerelmesitöl vált..., Én édes jobb kezem...) határozottan különböznek az eddigi kettőtől: ti. nem szabályszerü szerkezeti jegyeken v. félreérthetetlen motívumokon keresztül sugallják, hanem nyíltan kijelentik önnön (válasz)levél-voltukat. Ez a mozzanatot ebbéli önreflexív természete miatt viszont a qualitas-blokk munkatársai lennének hivatottak elkönyvelni.

A választott kategória (verses levél) létjogosultságához szerintem nem férhet kétség. Ha viszont az adatbázis az erre irányuló kérdést képtelen lesz egyetlen lépésben hiánytalanul 
megválaszolni, az egyértelmüen azt jelzi, hogy a konnotációs táblázat és a Qualitas-blokk adatstruktúrája újratervezésre szorul. ${ }^{478}$

Visszatérve a tárgyhoz: a Madách-Rimay-kódexek szerelmes versei között tehát összesen hat potenciális misszilis található (40\%). Ezek mindegyike udvarló jellegü. Az alaki és tipológiai egyformaságot mutató szövegcsoporton, vagyis a három darab kilencsoros Balassi-strófában írt válaszlevélen kívüli együttes tovább osztható egyfelől két ajándékkísérő (azon belül is egy virág- és egy ékszerküldő) költeményre, és egy harmadik énekre. Ez utóbbi a korai újkori magyar versanyag általam ismert egyetlen tétele, mely egy, a Török Imre 1485re datált verses köszöntőjéből ismeretes, a Liebesgruss-hagyomány valamiféle ismeretét feltételező közhelyet tartalmaz. Miféle óvatos következtetéseket vonhatunk le mindezekből?

A Balassi-életmüről nemcsak azt szokás evidenciaként kezelni, hogy idővel (legalábbis ha a Balassa-kódexbeli sorrendet kronológiai érvényünek fogadjuk el) a költemények rövidülnek, hanem hogy a kései versek karaktere is nagyban megváltozik. ${ }^{479} \mathrm{~A}$ Nagyciklus elején többször előforduló ajándékküldés motívuma példának okáért a Céliához írott darabok teljes egészéből hiányzik. A vizsgált korpuszra vetítve: jóllehet a rövidség valamint további, ehelyütt nem rendszerezett alaki jegyek, úgymint az akrosztichon és a kolofon teljes mellőzése - a Célia-versek példaértékét mutatja, az elemi praktikusság mégis Balassi legkorábbi szerzeményeinek eszményét idézi. Elgondolkodtató ugyanakkor, hogy a három eltérő levél-válfaj formailag is különbözik egymástól. A válaszlevelek három-három Balassi-strófát számlálnak, ezt terjedelemben alig haladja meg a két ajándékkísérő, melyek viszont bokorrímes felező tizenkettesben íródtak. A Ne gondold, szerelmem... kezdetü ének azonos utóbbiakkal azonos metrumban kelt, de a maga kilenc versszakával föltünően kilóg a tizenötök átlagából.

\section{A beszédnemek}

A feltérképezett retorikai eszközök - így a tria genera dicendi rendszerének - leírása szintén a konnotációs táblázat reszortja. A dolgozat értelmező fejezeteiben nemcsak az alapsémák, de azok fajtái szerint is csoportosítottam az anyagot: azt vizsgáltam, hogy az egyes énekek

\footnotetext{
${ }^{478}$ A textológiai fejezet adatmodellje egy ehhez hasonló problémát úgy hidalt át, hogy az egyes versváltozatokat leíró egyedi adatlapoktól elkülönítette az ún. szakirodalmi adatlapokat. A különbség a kettő között az, hogy míg az előbbi (hasonlóan a Qualitas-blokkhoz) az egyes szövegekböl közvetlenül kinyerhető információkat rögzíti, addig az utóbbi (akárcsak a konnotációs táblázat) a szekundér eredményeket; s e kettő értékei végül a gyüjtőadatlapon összegződnek.

${ }_{479}$ Vö. KoMLOvszKI Tibor, A Balassi-vers karaktere, Bp., Balassi, 1992 (Régi Magyar Könyvtár: Tanulmányok, 1), 7-11.
} 
egészükben vagy részleteikben vádolásként vagy védelemként, rábeszélésként vagy lebeszélésként, dicsőítésként vagy gáncsolásként fogalmazódnak-e meg. Az általános tapasztalat szerint noha a versszövegek retorikai értelemben vett terjedelme a leggyakrabban egyszerü (simplex), a beszédnemek szempontjából - függetlenül mindenféle egyéb minőségüktől - mégis csak igen ritkán mutatnak homogenitást. Ennek megfelelően mindegyik rekorddal kapcsolatban feltüntettem az összes hozzárendelhető értéket; azzal az előfeltevéssel, hogy ha egy-egy releváns belső korpusznak vannak preferenciái, azok igenis lehetnek beszédesek.

Az így kapott tarka mintázatból ugyan nem könnyü meghatározónak ítélhető nyalábokat azonosítani, de a kísérlet talán mégsem volt teljesen eredménytelen. A részfejezetekben (valószínűleg sürübben is a kelleténél) sikerült megállapítani azt az evidenciát, hogy a szerelmi költészetben persze a törvényszéki beszéd módozatainak is megvan a jogosultságuk, de az udvarlás alapvetően a rábeszélésen keresztül tud artikulálódni (az argumentáció ilyenkor általában oksági, hiszen a jó elérésére irányul), ugyanakkor a bizonyítás során célszerü személyi érvekként részletesen leírnia az áhított hölgy külső és belső tulajdonságait is.

\section{Szövegszervezö trópusok}

Míg a beszédnemek regisztrálása során tehát törekedtem azok minden kitapintható válfaját megemlíteni, az elocutio fogalmi körébe tartozó trópusok és figurák esetében csak néhány alapvető, az előzetes retorikai-stilisztikai igényü olvasatok szerint a versszövegek egészét meghatározó alakulatot ragadtam ki. Ennek tanulságait pedig a következőképpen látom összefoglalhatónak.

A felező tizenkettesekben írt udvarló költeményeket általában hasonlósági alapon létesült eszközök viszonylag kezdetleges használata jellemzi; ezekben a metaforika közhelyes és meglehetősen inkoherens.

Ez az állapotot tükrözi a felező tizenkettesben keletkezett didaktikus-moralizáló versek figurációja is, hozzátéve, hogy a szintén a hasonlóságra épülő példázatosság - érthető okokból - esszenciális kelléke ennek a verstípusnak.

Igen érdekes azonban, hogy a típus egyetlen parodisztikus változatában, a Szerelemtül csak kár... kezdetü latrikánus énekben az előbbieknél jóval virtuózabb eszközhasználat figyelhető meg. Egyetlen példán szemléltetve: az verscsoportban egyedül ehelyütt tetten 
érhető oxymoron kézenfekvő, de nem elengedhetetlen eszköze a paródiának, ezért alkalmazása kifinomultabb attitüdöt sugall.

Érdemes megfigyelni továbbá, hogy az a tanító célzatú alkotás, amely a többitől eltérően Balassi-strófában fogalmazódott meg (Hárfa ...at valahova juthat...) - és mint tudjuk, azoktól abban is különbözik, hogy mindenestül nélkülözi az erkölcsi megfontolásokat -, szintén feltűnően jól van kidolgozva.

A Balassi-strófában kelt udvarlóversek valamivel letisztultabbak: retorikai vonatkozásban is megmaradnak az egy-egy (általában valamilyen elödszövegre referáló) alakzat kifejtésénél.

Igazán látványos ékítetlenség azonban az Oly nehéz nem látnom... kezdetü éneket jellemzi.

Ezt önmagában a tipológiai minősége (ti. hogy magánbeszéd) nem indokolja - a másik hasonló jellegü, de elég sablonos képeket felvonultató darabra (Örüll, édes lelkem...) például nem áll meg.

De nem indokolja ugyanakkor a versmérték sem, mert a másik Palkó-versre sem áll meg: a Beborult, fölhözött... kezdetü poémát éppen a benne foglalt allegória enigmatikussága határozza meg.

Színvonalbeli különbség egyébként az ajándékküldő versek között is kimutatható. Az egyszerü ajándékküldő vers, ahogy a Látod ez gyöngyszemet... kezdetű is, értelemszerüen hasonlatokra épül.

Csakhogy a vizsgált anyagból sok tekintetben kiugró Egy szép rózsaszálat... kezdetű ének bőven meghaladja ezt a hipotézist, lévén már-már iskolásan: strófánként ill. más szerkezeti egységek mentén váltogatja az egyes figurák dominanciáját.

Egészében igaz továbbá, hogy az igehalmozásból - különösen, ha alliteráló - nemcsak nagyobb nyelvi kompetenciára, de az elődköltők virtuozitásának lényegibb felismerésére is következtethetünk.

Ugyanakkor a kommunikációs alakzatok reprezentálására választott aposztrophé önmagában - a fenti szempontok alapján mindenesetre - nem determinál semmit.

A szövegszervező trópusok értékelö összevetése azért bizonyulhatott kiemelten hasznosnak, mert rajta keresztül végre határozottan eltérő alkotói kvalitások rajzolódtak ki. Félreértés ne essék: azok megállapításához a retorikai eszközök puszta detektálása természetesen nem volt elegendő. Az igazán lényeges mozzanatok kinyerése ügyében a tényleges (jelen esetben is nélkülözhetetlen adalékokat szolgáló) interpretáció nem spórolható meg. Ráadásul - mint 
ahogy azt korábban is felvetettem - az összetettebb, plasztikus folyamatokat, vagyis a retorikai gépezet voltaképpeni müködését alighanem még ennek a háttértudásnak a birtokában is csak bajosan lehetne kemény adatokká transzformálni.

Azzal együtt - ld. mint fent, a beszédnemek tárgyalása során - a szóképek és alakzatok minél részletezőbb és kimerítőbb adatolása végső soron lehetővé tenné egy-egy tetszőlegesen szegmentált belső korpuszban, vagy akár a régi magyar költészet egészében végbemenő trópus-funkciótörténeti események kutathatóságát.

\section{A toposzok}

Az RPHA 17 adatstruktúrájának közzététele óta (az egyetemközi mühelyszemináriumokon folyó együttgondolkodás hozadékaként) a repertórium egy újabb fontos részterülettel gazdagodott: a toposzokéval. A dolog komplexitása indokolja, hogy a toposzok kutatását önálló munkacsoport végezze, de - mint arra már utaltam, lévén szó egy retorikai aspektusból egyértelmüen pozícionálható kategóriáról - azt viszont nem tartom feltétlenül szükségszerünek, hogy az adatbázis struktúrájában is önálló egységet képezzen.

A Madách-Rimay-kódexek szerelmes énekeiben kimutatható toposzok közül ehelyütt csak azt az egyet vettem nyilvántartásba, amelyikre a korábbi szakirodalom attribúciós érvként is támaszkodott; éspedig a távollét megélését. Idézzük fel: a versek szerzőjét Rimay Jánosban valószínűsítő Bóta László úgy vélte, hogy a többi Rimay versből közvetlensége okán elütő, de hitelességében gyanú felett álló Ne csudáld szivemet... kezdetü költemény ebbéli lírai alaphelyzetében a vizsgált anyag általánosan osztozik. Nos, ahogy a mellékelt táblázat is mutatja, ez a megfigyelés így nem teljesen pontos. A versek közül összesen csupán négyben jelenik meg a távolság képzete. Ez a teljes gyüjteménynek mindössze $27 \%$-a, de a kifejezetten udvarló szándékú versekre korlátozva sincs a fele (44\%). Továbbmegyek: még a verses leveleknek sem mindegyike tartalmazza azt - viszont amelyik alkotások tartalmazzák, azoknak nem mindegyike levél. Jól látható ugyanakkor, hogy az ekként körvonalazódó mikrokorpusz elemeit két tulajdonság mégiscsak összeköti: egyfelől nem felező tizenkettesben íródtak, másfelől (relatíve) tropológiai visszafogottság (tkp. ékítettlenség) jellemzi azokat.

Abból, hogy a tüzetes részben feltárt toposzok zöme - a távolléten kívül pl. az extramissziós látáselméletre visszavezethető állandósult képiség, a retia amoris, méz és méreg elegyültsége a szerelemben, a szerelmesek lélekcseréje, stb. - a példamutatónak tartott elődköltők (Balassi Bálint és Rimay János) eszközkészletében is megjelennek, a direkt hatás 
ténye persze szintén nem állapítható meg. A kontrollanyagként tekintett életművek és a vizsgált énekek applikációjának módozataiban tapasztalható eltérések azonban igen jelentékenyek lehetnek. Vegyük csak a szerelmi háló Rimay Szólítván nevemen... kezdetü énekéből is ismert toposzát, és rögvest szembetünik, hogy ahhoz képest a tizenötökben ennek kimunkáltsága jóval elnagyoltabb, beágyazottsága sokkal szervetlenebb; retorikai értelemben jobbára inkább panelszerü bővítmények az ornátusban, semmint az alapötlet részei.

\section{A reminiszcenciák}

A vendégszövegek azonosítása általában a textológiai munkacsoport feladatköréhez tartozik. Azok számos típusa közül most - dolgozatom érdeklődésének megfelelően - csak egyetlen alesetet vizsgálok: a Balassi Bálint vagy Rimay János hiteles verses életművét idéző reminiszcenciákat. ${ }^{480}$ Ilyesfajta szövegköziség a Madách-Rimay-kódexek vizsgált füzetének mindössze három énekében érhető tetten. Ezeknek az a tulajdonsága, hogy egyenként más és más imitációs stratégiát képviselnek, az alábbiak szerint.

A gyüjtemény sorrendjét követve elsőként a második tételben (Nagy példát adhatok...) ismerhető fel Balassi De mit gyötresz engem... kezdetű versének egy részlete:

Indulnak oly könnyen mert ők ide-s-tova, Mint szinte aszú ág szél fuallására, Böcsülik maguk közt s tartják legynagyobbra Azt, aki közülünk többet ejtett búra. ${ }^{481}$
Hajlók mert az rosszak minden hívságszóra, Mint aszú falevél szél fuallására, Becsülik és tartják magok közt nagyobbra, Ki közülünk köztök többet hajtott rajta. ${ }^{482}$

Emlékezzünk vissza: a szentenciózus alapmotívum közhelyességére Eckhardt világít rá, aki egy Janus Pannonius-elégiából adatolja azt. Vegyük hozzá azt is, hogy a két variáns diszpozíciója analóg egymással: mindkettő záró strófaként funkcionál a maga versegészében. Ami azért érdekes, mert a vizsgált anyag egy további intertextusára is többé-kevésbé ezek a tulajdonságok igazak. Az Ércnél, kősziklánál... kezdetű verses levél zárlatában kidolgozott aranymondás a Vásárhelyi daloskönyv Piros rózsa színü... kezdetü énekében fordul még elö; igaz, ott az akrosztichon megkívánta helyzetben, vagyis a harmadik versszakban. ${ }^{483}$

Gonosz szerencsének vélik azt mindenek, Imikor ember megbotlik,

Hasonlatosképpen azki hüségiben
Gonosz szerencsének

Botlását embernek

Nem mindenkor tarthatjuk,

\footnotetext{
${ }^{480}$ Jelen esetben reminiszcencia alatt több szintaktikailag összefüggő elem megfeleltethetőségét értem.

${ }^{481}$ BÖM, 73. sz., 9. vsz.

${ }^{482}$ RMKT XVII/12, 44. sz., 3. vsz.

${ }^{483}$ Ld. az Ércnél, kősziklánál... kezdetü énekről írott részfejezetet.
} 
/mástól megcsalatkozik, Avagy barátjától, szép szeretőjétől lazki messze távozik. ${ }^{484}$
Ha földre esését

És tagja törését

Abban mi nem láthatjuk,

De hogy az nyavalyás,

Kit elhagy kedves társ,

Igen bizonyithatjuk. ${ }^{485}$

A fentiek értelmében tehát kitapintható egy olyan gyakorlat, mely szerint az alkalmi költészetben evidens lehet valamely tetszetősen megfogalmazott közhelynek mint a peroratio illusztratív formulájának elkölcsönzése. Azon változtatni nyilván csak az adott szituációnak megfelelően szükséges, ám a versmértéket alkalmasint a vándorstrófa határozta meg. Kérdés persze, hogy ez a jelenség túlmutat-e a Szerelmes énekek c. füzeten.

Merőben más viszonyt tükröz a Balassi-örökséggel a Szerelmesitöl vált... kezdetü ének. Ennek beszélője - az imitációs kapcsolatot reflektálttá tevő figura, a hüpolépszisz segítségével - ${ }^{486}$ ugyanis ott kezdi el, ahol az elődje az Azmely keresztyén hü... kezdetű költeményét befejezte; tehát annak konkluzív zárlatára játszik rá a nyitómondatban:

Szerelmesétöl vált, nem csuda, az halált /hogyha fejére kéri,

Mert bújában halál orvosságot talál, Ifájdalma végét éri,

De az szörnyü válás végtelen kínvallás, /szivét örökké sérti. ${ }^{487}$
Szerelmesitöl vált valóban nagy kínt lát, Inincs vége keservének,

Bútúl bágyad, eped, álmot is nem enged /vehetni két szemének,

Ha megenyhiti is, nincs ép kedve mégis, Inem kell ir bús lelkének. ${ }^{488}$

Ahogy azt a vonatkozó részfejezetben kifejtettem, ez az eljárás leginkább az elődszöveg hiperboláinak mérséklését látszik szolgálni, s ebbéli módszere joggal hasonlítható a palinódiákéhoz. ${ }^{489}$

Az egyetlen szövegszerü Rimay-allúzió parodisztikus voltához azonban nem férhet kétség: a Szerelemtül csak kár... kezdetü versike az Encomia et effecta virtutum c. költemény morális tanításait jórészt ugyanabból a szókészletből gazdálkodva forgatja ki. E paródia alapgondolata - mint láttuk - szintén utalásértékü: Rimay egy másik alkotásában (a Valjon $s$ de mi haszon... kezdetűben) Ovidiusnak éppen azon passzusára hivatkozik, mely újfent csak a Szerelemtül csak kár... változatában torzul groteszkké.

Kövessen engemet az szemérmetesség, Ki minden dolgunkban ékesitő szépség,
Ajánlatja magát magával az szépség, Az ö ragyagása szívemben ugyan ég,

\footnotetext{
${ }^{484}$ RMKT XVII/3, 194. sz., 3. vsz.

${ }^{485}$ RMKT XVII/12, 53. sz., 3. vsz.

${ }^{486}$ A hüpolépszisz fogalmához ld.: SzILASI, A sas és az apró madarak, 17.

${ }^{487}$ BÖM, 83. sz., 3. vsz.

${ }^{488}$ RMKT XVII/12, 54. sz., 1. vsz.

${ }^{489}$ Vö. NAGY, i. m., 26.
} 
Fertelmességünkben ezáltal lehet vég,

Ha ez vezet minket, mint lovat zablás fék. ${ }^{490}$
Úgy visel bennünket, mint lovat zablás fék,

Kedvének vénekben nem találtatik vég. ${ }^{491}$

Összességében tehát kijelenthetjük, hogy a vizsgált anyagban nincs olyan reminiszcencia, melynek beillesztése megfelelne a közköltészetre jellemző kompilációs praxisnak, hiszen még az egyetlen direkt szövegátvétel is egy összetett szabályrendszer alkalmazását sejteti.

\section{A rímbokrok}

A textológiai munkacsoport a kezdetektől fogva úgy gondolkodott, hogy a repertórium szövegbázisának lehetőséget kell kínálnia a rímszavak összehasonlító vizsgálatára. ${ }^{492}$ Ezek költészettörténeti relevanciáját aligha szükséges bővebben argumentálnom, hiszen az évszázados hagyományokra visszatekintő nép/szép/kép/ép/tép rímtoposz is köztudottan e korpusz forrásvidékéről eredeztethető. ${ }^{493}$

A táblázatom végére hagyott oszlopban ismét csak megszürve közöltem a számításba vehető összefüggéseket. Azok között nem ismételtem meg az előző kategória, vagyis a reminiszcenciák hozadékát képező rímszó-ismétlődéseket; ezúttal a figyelmem kifejezetten a jóhangzást szolgáló elemi egységek újrahasznosítására irányult. Ezek beazonosíthatósága viszont, ha lehet, még az eddigieknél is problematikusabbnak mutatkozott. Egy-egy rímpár egymástól teljesen független kialakítása az egymáshoz térben és időben közel eső, megszabott eszközkészlettel operáló lírikusok munkásságában ugyanis nem hogy nem zárható ki, hanem éppen ellenkezőleg: nagyon is életszerünek tủnik. Ezért aztán csak azokat a kombinációkat regisztráltam, melyekben a véletlenszerüség esélye minimális. Ilyennek számítottam a legalább háromtagú szócsoportokat, illetve azokat a kéttagúakat, melyek egynél többször fordulnak elö a füzet tizenöt szerelmes versében. Mindez a következő eredményekhez vezetett.

Az első darab (Ne gondold, szerelmem...) két rímszava egybeesik Balassi Azmely keresztyén hü... kezdetü énekének egy belső rímpárjával.

Ó, siralmas szállás, kit kegyetlen válás /szegény fejemnek rendelt! Immár hova légyek, s ölemben kit végyek, /ha szántalan bú terhelt? Ó, szerencsétlen nap, ki elragad és kap
Ezer napja legyen életed egy napja, Jó szerencséd legyen te ügyednek apja, Vig kedvedet penig kezivel az kapja, Ki szerelmednek lött megköttetett rabja. ${ }^{495}$

\footnotetext{
${ }^{490}$ RÖM, 64. sz., 47. vsz.

${ }^{491}$ RMKT XVII/12, 47. sz., 2. vsZ.

492 BALÁZS-HAJdU, BOGNÁR, HEVESI, SinKA, i. m., 470.

${ }^{493}$ Vö. IMRE Mihály, Egy rímtoposz históriája (nép - szép - kép - ép ... tép), ItK, 1984, 399-426.
} 
/attól, ki híven kedvelt! $!^{494}$

Ami nemcsak azért érdemel említést, mert - ahogy arról már esett szó ${ }^{496}$ ezt a költeményt Balassi egy alkalommal legalábbis maga adta ki a kezéből ifjú barátja, Batthyány Ferenc inspirálására, s ettől talán nem függetlenül egyes részleteinek variánsai a közköltészeti forrásokban (jelesül a Vásárhelyi daloskönyvben) is megjelennek. Hanem azért is, mert az Azmely keresztyén hü... egy másik strófája szövegszerü párhuzamba állítható a vizsgált versgyüjtemény Szerelmesétöl vált... kezdetű versével.

A harmadik darab (Ki-ki terhét vállán...) több rímszava Rimay János $E z$ asztalhoz mostan ... ill. Itt egy asztalt látunk... kezdetü verseinek együttes besugárzását tükrözi:

Gözködö italnak se legyen itt helyje, Tobzódással magát senki se terhelje, Mit gyomrában betölt, azt meg is viselje, Okádta moslékát se nyalja se nyelje ${ }^{497}$

Mert mint avult börit kígyó nem viseli, Csintalanságával magát nem terheli, Így okos keresztyén vétkét nem neveli, Rútságát szépségén örömest cseréli. ${ }^{499}$
Ki-ki terhét vállán közülünk viseli, Az az mester ember, ki búját jól éli, S hírit ö titkának maga nem neveli, Boldogsága részét csendes kedvvel éli.

Engem hát szerelmem, ki tüziben nevelt, Nem csudálhatom-e, hogy lángom el nem nyelt? Ki magának most is marasztott bennem helt, Érezö gyötrelmim adhatnak nektek jelt.

Lelkemet rossz gonddal mert nem is terhelem. ${ }^{498}$

Ezen felül az Encomia et effecta virtutum c. ének textusát pedig a Szerelemtül csak kár... kezdetű ének veszi alapul. Ugyanez nyitóstrófájának minden sorában egy további Balassivers, a Szít tüzet Zsuzsánna... kezdetü negyedik szakaszának rímszavait lesi el:

Kártyát játszván velem, vet szivet tromfomra, Kit az bölcs szerelem így magyaráz jómra, Mondván: Ne féll, söt vígan éll, /mert tied az a szép személ, Veres levél tromfodra kél, lcsak azért, hogy jót reménll, Semmi gonoszt te ne véll! ${ }^{500}$
Szerelemtül csak kár, hogy tiltunk szép személt, Hajlandóság nélkül mert soha egy sem élt, Jupiter is szépnek tilalmat adni félt, Söt kedvezni nekik tiszti szerint is vélt. ${ }^{501}$

\footnotetext{
${ }^{495}$ RMKT XVII/12, 43. sz., 9. vsz.

${ }^{494}$ BÖM, 83. sz., 2. vsz.

${ }^{496}$ Ld. a Szerelmesitől vált ... kezdetű éneket tárgyaló részfejezetben.

${ }^{497}$ RÖM, 57. sz., 3. vsz.

${ }^{498}$ RMKT XVII/12, 45. sz., 1-4. vsz.

${ }^{499}$ RÖM, 64. sz., 30. vsz.

${ }^{500}$ RÖM, 86. sz., 4. vsz.

${ }^{501}$ RMKT XVII/12, 47. sz., 1. vsz.
} 
Ahogy azt a Rimaytól legutóbb idézett két énekben is láttuk, előfordulhat, hogy egyes rímbokrok egy adott életmüvön belül többször is (részleges v. teljes) felhasználásra kerülnek. A Balassi-életmüben is akad erre példa: a fenti rímszavak zöme megismétlődik a Mint az szomjú szarvas... kezdetű zsoltárparafrázisban (félj/[reménlj]/élj/vélj). ${ }^{502}$ Arról ugyan nem lehetek teljes mértékben meggyőződve, hogy a Ne gondold, szerelmem... és a Semmi állat nincsen... kezdetü énekek szerzője egy és ugyanaz a személy volna, ám mégis úgy vélem, hogy a következö, a korábbi megállapítások érvényében a többször, többféleképp mintául vett hatodik Célia-versre (Azmely keresztyén hü...) visszavezethetö rímpár továbbfejlesztett változata a tizenötökben inkább képez intra-, semmint intertexust:

Ezer napja legyen életed egy napja, Jó szerencséd legyen te ügyednek apja, Vig kedvedet penig kezivel az kapja, Ki szerelmednek lött megköttetett rabja. ${ }^{503}$
Semmi állat nincsen földön nyomorultabb, Szerelem töriben akadott szegény rab, Elméje bujdosik, mihelt felkel az nap, Ejszaka is szeme semmi álmot nem kap. ${ }^{504}$

És végül az utolsó darab (Beborult, fölhözött...) kétségbevonhatatlanul egy Balassi-ének (Julia szózatját, kerek ábrázatját...) rímeinek emlékével készült:

Egyenlö két rózsa, kinek mind pirosa, lállapatja, színe egy, Sem egy ágon termett, kit zöld levél fedett, Inem hasonlóbb két ért meggy, Mint ez Juliához, kinek szép voltához /gerjedek, mint Aetna-hegy. ${ }^{505}$
Sokféle szerencséd ne lehessen, csak egy, Búval, bánattal is soha ne ismerkedj, Épen álljon a hegy, Melyen szám ízihez terem szép piros meggy. ${ }^{506}$

Mindent egybevetve a kolligátumok Szerelmes énekek c. füzetében tetten érhető szövegkölcsönzéseket illetően az alábbi szabályszerüségeket figyelhetjük meg.

Az utóbb tárgyalt két kategória leginkább szembeszökő tulajdonsága, hogy azokban a biztosra vehető elődszövegek mennyisége összességében nem is olyan kiugróan nagy, mint azt a korábbi szakirodalom alapján feltételezni lehetett. ${ }^{507}$ A tizenötökben csupán négy Balassi-vers emléke azonosítható minden kétséget kizáróan, s azok zömmel - egészen pontosan egy kivételtől (De mit gyötresz ...) eltekintve - a Célia-ciklusból valók. ${ }^{508}$ A formai jegyekről szólva már valószínűsíthettük, hogy e téren a gyüjtemény a Célia-versekben látja

\footnotetext{
${ }^{502}$ BÖM, 93. sz., 7. vsz.

${ }^{503}$ RMKT XVII/12, 43. sz., 9. vsz.

${ }^{504}$ RMKT XVII/12, 48. sz., 1. vsz.

${ }^{505}$ BÖM, 78. sz., 2. vsz.

${ }^{506}$ RMKT XVII/12, 57. sz., 8. vsz.

${ }^{507}$ Vö. BÓTA, i. m.; RMKT XVII/12, 733-737.

508 A Nagyciklusból kibontakozó (ön)életrajzi narratíva értelmében tehát azok a Balassi-énekek, melyeknek jelenléte a vizsgált korpuszban teljes bizonyossággal megállapítható, kivétel nélkül a Júlia-szerelem lezárultával keletkeztek.
} 
követendő példát: ez a sejtés most a ciklus 6., 9. és 10. tételének szövegszerü ismeretén keresztül látszik beigazodódni.

A Rimay-életmű vonatkozásában a lista mindössze két további elemmel: az Encomia et effecta virtutum ill. a Leges Mensales c. alkotásokkal bővíthető. Jelezném, mindkettő kizárólagosan a tárgyalt korpusz közvetlen környezetéböl, vagyis a kolligátumok első kötetének lapjairól maradt ránk; a Szerelmes énekek után következö 4. és 5. sz. füzetben olvashatóak. $^{509}$

Szabadjon ehelyütt újra fölidéznem Bóta László idevágó fontos megfigyelését is, mely szerint azok a költemények, melyek ritmusukban a Balassi által kialakított mintát utánozzák, az intertextusok viszonylatában - leszámítva a Szerelmesitől vált... kezdetű ének egy rövidke allúzióját - érdektelenek. ${ }^{510}$

Ide tartozik még, hogy a rímek „szemantikai jelentéshálózatát”,511 a vizsgált utódszövegek nem foglalják magukba, tehát rímtoposzok továbbörökítésére vagy kialakítására nem tesznek kísérletet.

A tágabb összefüggések keresése során pedig - föként, ha további, a fenti táblázat rovatain részben kívül eső szempontokkal is számolunk - egy újabb izgalmas összefüggést ismerhetünk fel; mégpedig azt, hogy a jelenlegi formájában értett versegyüttest keretező két hosszabb, nem Balassi-strófában írott darabnak (vagyis a Ne gondold, szerelmem... és a Beborult, fölhözött... kezdetünek) egyaránt meghatározó tulajdonsága, hogy zárlatuk egy-egy Célia-vers rímszavaiból építkezve fejez ki jókívánságot. E tapasztalat birtokában pedig azt a felvetést is megkockáztathatjuk, hogy a tizenötök imitációs technikájában a legnagyobb retorikai-poétikai szervezettség általában a záróstrófa létrehozásában csúcsosodik ki.

Mindennek a végére érve nincs más hátra, mint hogy megpróbáljak elfogadható magyarázattal szolgálni arra, hogy minek köszönhetően jött létre e dolgozat voltaképpeni tárgya, tehát a versgyüjtemény.

A kolligátumok teljes anyagában egyedüli rendezőelvnek az összeállító Madách Gáspár érdeklődési köre bizonyul, a tartalom pedig valamelyest az ő lehetőségeire is utal. A kérdés tehát föleg az, hogy miért vállalkozott egyáltalán a poétai önarcképét a harcos erkölcsvédő szerepében megrajzoló költő éppen ezeknek a szerelmi tárgyú emlékeknek megőrzésére?

\footnotetext{
${ }^{509}$ Vö. Madách-Rimay-kódexek, I, 45-56. ill. 70-71.

${ }^{510}$ Vö. BÓTA, i. m., 23.

${ }^{511}$ IMRE Mihály, i. m., 405.
} 
A legtriviálisabb megoldás persze az volna, ha a füzet verseinek szerzőségét Rimay Jánosnak tulajdonítanánk. Ebben az esetben a válasz értelemszerüen úgy hangoznék, hogy mivel Madách Gáspárnak feltett szándéka volt összegyüjtenie a rajongva csodált nagybátyja nagyra becsült szerzői hagyatékát, ezért mérlegelés nélkül írta össze annak minden általa hozzáférhető részletét. Ezt ráadásul nem is zárhatjuk ki teljes bizonyossággal. Csakhogy egyrészt az előzetes vizsgálódásokból egyértelmüen kiderült, hogy a tárgyalt énekek színvonala és/vagy hangütése gyakran nem egyeztethető össze a hiteles Rimayírásművekével; másrészt annak ellenére, hogy a szóban forgó gyüjteményt a korábbi szakirodalom sem tekintette feltétlenül monolitikus egységnek, eleddig keletkezésüket mindig egyetlen szerzőtől volt szokás származtatni ${ }^{512}$ - a jelen dolgozat vonatkozó fejezete viszont e konszenzusra mégiscsak a gyanú árnyékát veti. Arra ugyanakkor nem tudok határozott választ adni, hogy ez esetben pontosan hány szerzőt is kellene feltételeznünk a korpusz mögött: a fenti kísérlet épp azt hivatott szemléltetni, hogy az énekek egyes tulajdonságait kategorizálva markánsan elkülönülni látszik egy-egy kisebb szövegcsoport, ám a kategóriák együttes értelmezése adott esetben ezek határvonalainak nemcsak megerősítéséhez, de felszámolásukhoz is vezethet.

Úgy hiszem, e jelenség magyarázatához elég egyet visszalépnünk. Vagyis tartsuk fenn a feltételezést, hogy Madách Gáspár ezeket a verseket azért másolta le, mert azok részét képezték Rimay hagyatéknak - és vegyük hozzá, hogy a nem (vagy nem teljes egészében) szerzői hagyaték is irodalmi hagyatéknak minősül. Ez esetben megfejtésként tehát az kínálkozna, hogy a tizenötök egymáshoz mérve azért mutatnak nagyfokú differenciáltságot és többirányú átjárhatóságot is egyszerre, mert azok nem egyelten költő bizonytalan kimenetelü szárnypróbálgatásainak, hanem egy egyetlen költő köré szerveződő kvázi műhely (kör, iskola, stb.) tevékenységének volnának eredményei. Az utóbbi költő lehetne Rimay János.

Az elsősorban intézményesítő törekvéseiről ismert költő környezetében ugyanis léteznie kellett egy olyan literátus közegnek is, melynek az ő elitista szemléletével össze nem egyeztethető irodalmi produktumait felvállalni ill. továbbhagyományozni akkor sem nagyon

\footnotetext{
512 Vö. RimaY János Munkái, 5-36.; BARos, i. m., 187.; RimaY János Összes müvei, 163; BóTA, i. m., 24., VARGA, Tallózások Madách Gáspár körül, 70.; RMKT XVII/12, 70-84.; PIRNÁT, Balassi Bálint poétikája, 100.; ZEMPLÉNYI, Müfajok reneszánsz és barokk között, 142.; BALÁZs-HAJdU, A romlás alakzatai, 25. Itt jegyezném meg, hogy a Régi Magyar Költök Tára vonatkozó részének címe (Rimay-Madách-kódexek ismeretlen szerzötöl származó versei) félreértésre adhat okot, a kötet alcíme (Madách Gáspár, Egy névtelen [!], Beniczky Péter, Gróf Balassa Bálint, Listius László, Esterházy Pál és Fráter István versei) pedig egyenesen megtévesztő, mert azt sugallja, hogy az ide sorolható énekek mindegyike - beleértve tehát a Pöngését koboznak... kezdetủ ill. $A z$ tekintetes és nagyságos Hadady Wesselényi Ferenc uram önagysága nevére szereztetett versek címü költeményeket is - egyetlen szerző alkotásai lennének, noha ezt a kérdés érdemben eddig senki nem vizsgálta. A problémát nemrégiben Szigeti Csaba is érintette. Vö. SzIGETI Csaba, Az magyar verseknek annya, Vasi Szemle, 2013/4, 394.
} 
állhatott érdekében, ha része volt a megalkotásukban, vagy legalább egyáltalán tudomása volt azokról.

Ennek a mindenestül alkalomszerü, az elődköltők (Balassi Bálint és Rimay János) retorikai-poétikai teljesítményeit a popularizálódás széles útjára terelő gyakorlatnak lehet elsődleges dokumentuma a Madách-Rimay-kódexek Szerelmes énekek c. füzetében megörökített tizenöt vers. 
APPENDIX 


\section{A Rimay-örökség Madách Gáspár tollán}

\section{A szöveggondozó Madách Gáspár}

A nem kifejezetten első vonalbeli 17. századi verselőnek, Madách Gáspárnak irodalomtörténeti pozicionálását a mai napig általában három, a 20. század legelejéről eredő közhely felmondásával szokás megoldani: Madách Rimay János költő-tanítványa volt, a Rimay-vershagyaték egyik gondozója, aki sokat tett e hagyaték kinyomtatásának ügyében is. Ezeknek a megállapításoknak azonban az a szépséghibájuk van, hogy csak bizonyos megfontolások figyelembevételével tekinthetők érvényesnek. Az utóbbi kettő persze szorosan összetartozik, már csak azért is, mert - szemben az elsővel - azok nem poétikai érvek mentén, hanem némiképp müvészeten kívüli bizonyítékok, jelesül irodalmi érdekü levelek alapján körvonalazódnak. Hagyományosan három ilyet tartanak számon, ám ezek jellemzően több kérdést implikálnak, mint ahányat megválaszolnak, és összetartozásuk jellege is kérdéses.

Madách irataira, a Madách-Rimay-kódexek néven ismert kolligátumokra annak idején Radvánszky Béla akadt rá, felfedezéséről először az Irodalomtörténeti Közleményekben számolt be. ${ }^{513}$ Radvánszky a költő portréja mellett mindjárt megrajzolta az irodalomszervezőét is, mégpedig az Ipolyi Arnold által azt megelőzően közreadott Rimaylevelezés vonatkozó tételei nyomán. A levelekből kinyerhető koncepció végpontjának jelenleg Kőszeghy Péter A titokzatos SOLVIROGRAM c. tanulmánya tekinthető. ${ }^{514}$ Elöljáróban ezzel - vagyis a szöveggondozó Madách szerepéről a legutóbbi időkig kialakult képpel - szemben kínálnék egy lehetséges alternatívát.

Adva van tehát egy Madáchnak címzett enigmatikus levél, melynek kilétét titkoló szerzője a Rimay halálát követő intézkedéseiről számol be, s mindjárt puhatolózásba is kezd a hagyatékot illetően. ${ }^{515}$

Jót akaró bizodalmas uramnak, barátomnak, mint atyámfiának, szolgálok Kegyelmednek, az Úristentöl sokáig tartó egészséget kívánok. Uram, az én kedves s mulatságos companiám reménlötlen megfelettlenüle, szívbéli

\footnotetext{
${ }^{513}$ RADVÁNSZKY Béla, Sztregovai Madách Gáspár versei, ItK, 1901, 129-152.

${ }^{514}$ KÖSZEGHY Péter, A titokzatos SOLVIROGRAM, Korunk, 2008/7, 29-35. A dolgozat azóta további érvekkel és feltevésekkel gyarapodva a szerző újabb monográfiájának képezi egy fejezetét. Vö. KösZEGHY, Balassi Bálint: Magyar Amphión, 213-232.

${ }^{515}$ RIMAY János államiratai és levelezése, 357-358.
} 
szomorúságomval. Legyen az Úristennek szent akaratja, kicsiny szolgálatomval, éltében hogy szerettem, böcsültem az embert, bizonyétottam. [...] Döbröcenben nyomtatott dictionáriumja felöl, kihez foglalva vagyon a Cato morális könyvecske is, emlékezett vala szegény Rimay uram, hogy általküldi bizonyos embertöl ide, nekem. Ha lehet, efficiálja Kegyelmed. Könyveinek az aprójában jó emlékezetivel megtartásáért, ha méltó kérésem, részeltessen, Kegyelmedet bizottan kérem, e dolog ne értessék Kegyelmeden kívül mástól: szegény atyánkfiának a paripája, noha idös már, de ha bontakozása nincsen s eladó leend, adja értésemre kegyelmed, ha hozzá férnék, másnak nem bocsátanám. [...] Kegyelmed tartson barátjának, elégségemböl szolgálok. 11. die Decembris anno 1631. Kegyelmed szolgáló barátja, $N$...

Ezzel össze van fogva egy Madách által írott levélfogalmazat, mely Rimay irodalmi örökségének siralmas állapotáról ad hírt: annak romlását szerinte érdektelenség és avatatlan kezek okozzák. ${ }^{516}$

Sokat törödvén elmémben Kegyelmed jó híre s neve felöl való tudakozásomban, s miképpen lehetne módom levél által való Kegyelmeddel mintegy szembenlételem. $S$ nem is türhettem, hogy Kegyelmed írásommal meg nem találnám. Azért, sincere amice et frater mihi charissime, szivem szerint kívánnám, ha oly helyütt akadnánk együvé, azhon én Kegyelmedet egészséges állapatjában láthatnám és Kegyelmeddel sok rendbeli dolgokrúl beszélhetnék, mert ugyanis az az gyönyörüséges állapat, azhon igaz barátságos emberek jóakaró barátjokot és atyjokfiát egészséges, örvendetes állapatban láthatják s jó hire, neve terjedezésének virágoztatásával is hallhatják életét. Eddig is levelemmel megtaláltam volna kegyelmedet, de bizonyos oda menö emberre nem akadhattam, ki levelemet Kegyelmed kezében praesetálhatta volna, Kegyelmed is penig idegenséget mutatván mihozzánk, szegény atyafiaihoz, sem üzenetivel, sem levelével meg nem látogat, az Kegyelmed szolgálatára nem ébresztget bennünket, holott hallván bizonyos embertöl Kegyelmed becsületes elméjének hatható éles voltát mind magyar szóknak kimondásában s mind penig irásának tudományában. Akarnám, ha Kegyelmed az mi szegény, Istenben elnyugodt Rimay János atyánkfiának néminemő jó híre, neve s irásának világositására való terjedezést és élemedést adhatna s támaszthatna, s izzasztó elméjéböl való irásának munkája feledségben semmi se ne jutna országunkban, mert itt immár mi tájunkon igen hanyatlásra juta s munkájának szép, fontos magyarsággal folyó, elméje bágyasztó ékes irása, s oly emberek is forgatják immár irásit, azkinek elméjének csekély volta nem is érdemlené, s nemhogy az olvasásra kezében is vehetné, nem értvén, eszében sem vevén bölcs irásának magyarságát, de jobb volna, hogy távul kerülne s fekete szint ne adna s rázna irására mód nélkül való olvasásával, mint az sánta ló elöbb botlásával, lábaival való sárban lépésének fecskendésével, tiszta szép ékes tudományú írását sárositaná s homályositaná rebegö olvasásával. Bizonyoson írhatom Kegyelmednek, hogy oly megbúsult elmével vagyok az irásinak tékozlási felöl, csak meg nem epeszt elmémnek töredelmessége, holott látom szegény atyánkfiának egyszersmind mind testében s mind irásának ékességes voltában meghalni, s nem is reménlhetek háza s maradéki közül, hogy irására jó gondot viselvén, világosságra való terjedezést adhatna. Mindazonáltal egy írásocskáját kapván kezemben, leirván Kegyelmednek levelemben includálván megküldöttem, mint kesergi legyen szegény atyánkfia fiacskájának, Jancsikának halálát és verseivel mint ékesgesse. Hogy penig Kegyelmed énfelölem is oly itéletben ne legyen, hogy csak henyélésben töltsem idömet, ime egynéhány énekecskét, kiket megfordítottam cseh nyelvböl, küldtem Kegyelmednek.

Kőszeghy feltételezi, hogy a rejtélyes levél szerzője s a fogalmazvány címzettje egyazon személy, nevezetesen Ráday András. Ezt többek között azzal is magyarázza, hogy mindkét irat atyafiságos viszonyt emleget, márpedig Madách és Ráday (a költő húga, Zsófia révén) ténylegesen sógorok voltak. Hovatovább közöttük már korábbról is felsejlik valamiféle együttműködés lehetősége: a harmadik gyakran idézett forrásban, Ráday egy 1629. március

516 Uo., 358-359. A fogalmazatot Radvánszky Béla nem ismerteti, arról nem mond véleményt. A két írás tartalmi összetartozására elöször Eckhardt Sándor figyelmeztet, vö. RÖM, 168. 
25-én kelt levelében azt kéri Rimaytól, hogy azokat az énekeket, melyek Madáchnál is megvoltak, küldje el a bécsi nyomdász Ferenczffynek. ${ }^{517}$

Szolgálatomot ajánlom Kegyelmednek, mint bizodalmas uramnak, sógoromnak. Istentöl Kegyelmednek kedves házanépivel egyetemben egészséges életet és minden lelki, testi jókat adattatni kívánok. [...] Küldje fel Kegyelmed az virtusról componált éneket Ferenczffy uramnak. Ezeket az énekeket, kik Madách Gáspár uramnál voltak minden argumentomival, úgymint harminchétnek kell lenni, jó corrigálással, ha Kegyelmednek tetszenék, egy csomóban ki kellene nyomtattatnunk az Kegyelmed emlékezetire, s méltó és érdemesek is arra, mindeniket általolvasván és írván, azmint tudom immár, kár, hogy egyet együl, más akképpen vétkesen vesztegetnek, bár magamra bizná Kegyelmed az véghezvitelét. Kegyelmed akaratját adja tudtomra, és melyik könyvnyomtató bötüit javallaná inkább. [...] Tartsa meg az Úristen Kegyelmedet egészségben. Datum Szécsény, die 25. Martii, 1629. Kegyelmednek jóakaró sógora szolgál Kegyelmednek, Ráday András.

Madách (a keze írásában fennmaradt füzetek egyikének tanúsága szerint ${ }^{518}$ ) valóban közelébe került az emlegetett gyüjteménynek. Csakhogy a füzet nem a Ráday által kért énekeket tartalmazza, csupán azok argumentumait - méghozzá elég kuszán és félbehagyottan. ${ }^{519} \mathrm{Ez}$ a tény pedig különös nyomatékot adhat Ráday egyes kitételeinek, mármint hogy „,minden argumentomaival” ill. „jó corrigálással”. Ennek belátásával azt lehet gondolni, hogy amint Ráday levele utalhat együttmüködésre, úgy utalhat akár a botcsinálta szöveggondozó megkerülésének szándékára is.

Bizonyos, hogy Madách torzóban maradt levelében Rimay János hátrahagyott írásainak egy megbízható kiadását sürgeti. Abban ugyanakkor - láttuk - olyasvalakit szólít meg, aki felől tudakoznia kellett. Akiről azt hallotta, igen tehetséges a magyar szavak kimondásában és leírásában. Akihez nemhogy ő maga nem bejáratos, de még csak alkalmas embert is nehezen talál, aki kézbesíthetné levelét. És akinek szemrehányást tesz, amiért az nem bíztatja szolgálatára sem személyesen, sem pedig írásban. Mindezek ismeretében nehezen fogadható el az a régebbi alapvetés, mely szerint a fogalmazvány direkt válasz lehetne a hozzáfogott misszilisre. ${ }^{520}$

Tervezett levelének elkészült részében Madách csatolmányokat is ígér. Azoknak kikövetkeztethetően legitimációs funkciójuk lehet, vagyis önnön érdemességét igyekszik jó

\footnotetext{
${ }^{517}$ RIMAY János államiratai és levelezése, 320-321.

${ }^{518}$ Madách-Rimay-kódexek, I, 129-196.

${ }^{519}$ E füzetben Madách bizonyára olyan anyagot másolhatott össze, mely addig nem volt a birtokában. Ennek megfelelően csak az argumentumok egy részét és (többnyire) az azokhoz tartozó énekek kezdősorát írta le. Hogy a 15 argumentum kétséget kizáróan a Ráday emlegette gyüjteményhez tartozik, Klaniczay Tibor bizonyította a Hozzászólásban, mint ahogy azt is, hogy e sokáig elveszettnek hitt szövegcsoport (a 37 ének) azonos az Istenes énekek rendezett kiadásaiban a Balassi-epicédiumot megelöző, 38 versböl álló egységgel. (KLANICZAY Tibor, Hozzászólás Balassi és Rimay verseinek kritikai kiadásához, 265-338.) Az egy tételnyi differenciát az okozza, hogy a Madách-féle másolat bár tükrözni látszik az egység első részének sorrendjét, de nem tartalmaz semmilyen utalást annak 13. darabjára, az Ez világ mint egy kert... kezdetü versre. Biztosat mondani erről nehezen lehet. Klaniczay is több eshetőséget vázol. (Uo., 289.)

${ }^{520}$ RÖM, 168.
} 
érzékkel megválasztott szövegekkel bizonyítani. Az egyik ilyen tehát Rimay azon verse, melyet az kisfiának halálára szerzett. Ennek kizárólagos birtoklása valóban a két költő közötti bensőséges viszonyról árulkodik. De ugyanitt beszámol saját munkáiról, néhány cseh nyelvből fordított költeményről is. A fogalmazathoz jelenlegi formájában nem tartozik melléklet, ugyanakkor a Madách-Rimay-kódexek megőrizték az Úr engem sanyarita... kezdősorú verset. ${ }^{521}$ Ahogy fennmaradt azokban négy csehből fordított, 1636-ra datált, versföiben Czobor Anna nevét viselő istenes ének is. ${ }^{522}$ Ha ezek azonosak az előbb említettekkel, akkor bizonyos korábbi eredményeket szintén szükséges revideálni. Egyrészt a levélfogalmazat nem 1632 végén vagy 1633 elején keletkezett, ${ }^{523}$ hanem valamivel több, mint három évvel később, éppen a Madách- és Ráday-család között kipattant örökösödési vita idején. ${ }^{524}$ Másrészt az akrosztichonos versek azt sugallják, a címzettet érdemesebb lenne talán az akkortájt elözvegyült Czobor Anna környezetében keresnünk. ${ }^{525}$

De úgy hiszem, Madách Gáspárnak a Rimay-kiadástörténetben játszott szerepéről legjobban a Jancsika haláláról szóló vers hagyományozódása segít fogalmat alkotnunk. Annak ugyanis a Madách-Rimay-kódexek képezik az egyetlen ismert forrását. Vagy azért tehát, mert a fogalmazat sosem lett elküldve, vagy mert címzettjének mégsem volt elég affinitása egy teljesebb Rimay-kiadásban való közremüködésre, vagy más okból - az Úr engem sanyaríta... a maga korában nem jelent meg nyomtatásban. Ez viszont arra utal, hogy az irodalomszervező Madách személyében alkalmasint egy nagyon elkötelezett, de amúgy elszigetelt és súlytalan örököst tisztelhetünk.

\section{A versszerzö Madách Gáspár}

\section{1. Madách mint moralizáló versek szerzöje}

A versszerző Madách Gáspár kanonikus helyét Radvánszky Béla ekként határozta meg idézett tanulmányában: ,[k]étségtelen, hogy a költészetben Madách Rimay tanítványa, de valamint

\footnotetext{
${ }^{521}$ Madách-Rimay-kódexek, I, 69-70. Kritikai kiadása: RÖM, 67. sz.. E két vers (a levélben említett és a kódexben fennmaradt) azonosságát Pirnát Antal ismeri fel, vö. A magyar irodalom története 1660-tól 1772-ig, 25 .

${ }_{522}$ Madách-Rimay-kódexek, III, 19r-28v. Az énekek kritikai kiadása: RMKT XVII/12. 2-5 sz.

${ }^{523}$ Vö. KÖSZEGHY, A titokzatos SOLVIROGRAM, 32. Az énekek keletkezése mint a fogalmazvány terminus post quem-je azért is tünik valószínübbnek, mert közvetlenül Rimay halála után Madách aligha számolhat be a dolgok ilyesforma állásáról.

${ }^{524}$ Vö. VARGA, Tallózások Madách Gáspár körül, 73.

${ }^{525}$ Vö. RMKT XVII/12, 718.
} 
hogy Rimay János nem érte el nagy mesterét, úgy Madách sem mérközhetik mesterével. „526 Radvánszky maga sem tudta tehát túlbecsülni felfedezettjét, még azzal együtt sem, hogy némely önmagában elégtelen filológiai megfontolás alapján durván összekeverte a két költő alkotásait a talált anyagban. Ezzel a ténnyel elsőként a Rimay műveinek kritikai kiadását előkészítő Eckhardt Sándor szembesült, aki a kiigazítások fényében végül a következőképpen árnyalta a Madáchról alkotott képet: „, halvány Rimay-utánzó, anélkül, hogy nagybátyja formai tehetsége iránt a bámulaton kívül kellö érzékkel bírt volna. ${ }^{, 527}$ Ezt aztán később - a Spenót oldalain - Pirnát Antal többek között azzal a megfigyeléssel egészítette ki, hogy a szövegszerüen is kimutatható legközvetlenebb inspirációt Madách számára a Dicta Catonis néven ismert vulgáretikai kézikönyv szentenciózus disztichonjai jelentették, ${ }^{528}$ ami leginkább abban mutatkozik meg, hogy a madáchi vershagyaték nagyobbik felének szolgál egy-egy Catóénak mondott kétsoros alapötletül. Mint azt Varga Imre meggyőzően bizonyította, átdolgozásaihoz Madách a Libellus Elegantissimus címen megjelent, a latin mondásokat magyar prózafordításban is közlő 1591-es debreceni edíció szövegét vette alapul, méghozzá valószínüleg azt a példányt, melyet a neki címzett talányos levél mint „,morális könyvecskét” emleget; vagyis a Rimay Jánosét. ${ }^{529}$

Az újabb népszerü kiadások (antológiák és szöveggyüjtemények) ennek ellenére csak a legritkább esetben szemezgetnek a versanyagnak ebből a részéből, általában megelégszenek egyes szórakoztatóbb poémák közzétételével, jóllehet azok nemcsak kevéssé tipikusak, de a szerzőségük is vitatott. ${ }^{530} \mathrm{~A}$ jelenség nyilván nem független attól, hogy ezek az alkotások még inkább a vaskosságuk okán tarthatnak számot az olvasók érdeklődésére.

Dolgozatom második felében, melyben immár Madách Gáspár költői gyakorlatát tárgyalom, elsősorban azt vizsgálom, milyen szerzői attitűd érhető tetten a gyüjtemény e kétféle típusú anyagában.

Tudni való, hogy Madách csak ritkán tekinti lezártnak vagy befejezettnek egy-egy müvét. Erre utal egyebek mellett az is, hogy kedves témáit alkalomadtán újra és újra megverseli.

\footnotetext{
${ }^{526}$ RADVÁNSZKY, 130.

${ }^{527} \mathrm{RÖM}, 3$.

${ }^{528}$ Vö. A magyar irodalom története 1600-tól 1772-ig, 137.

${ }^{529}$ VARGA, Tallózások Madách Gáspár körül, 74., ill. RMKT XVII/12, 669.

${ }^{530}$ Ld. Pajkos énekek, szerk. STOLl Béla, Bp., Szépirodalmi, 1984 (Magyar Ritkaságok), 95, 138-139; Magyar Erato, szerk. RÉz Pál, Bp., Magvető, 1987 (Magyar Hírmondó), 29-33.; Szöveggyüjtemény a régi magyar irodalomból, szerk. KovÁcs Sándor Iván, II, Budapest, Osiris, 2003, 201-207. Az egyetlen kivétel az Orlovszky Géza által szerkesztett Szelence, mert az közzéteszi a Jó szerencsében magadat el ne higgy... kezdetü verset, ld.: http://szelence.com/madach/index.html. (2016. 01. 30.)
} 
Legtöbbször alighanem azt közülük, melyhez a Libellus Elegantissimus alábbi tantételéböl merített: ${ }^{531}$

Nil temere uxori de servo crede querenti

Sepe etenim mulier quem coniunx diligit odit

Ezt a debreceni kiadás a következőképpen fordítja:

Az te feleségednek, mikor az szolga felöl panaszolkodik, ne higgy ok nélkül; mert gyakorta az asszonyállat gyülöli azt, azkit az ö férje szeret.

A fenti alapgondolat négyféle kidolgozásban maradt fenn Madáchtól. ${ }^{532}$

Egy ízben a latin nyelvü disztichonokhoz fabrikál egystrófás rímes fordításokat, s azokat a kolligátumok egy füzetében tisztázza. ${ }^{533}$ A munkálat során láthatóan igyekszik sorban haladni, ám végül egy tévesztést követően a beírás megszakad; ebből adódik, hogy noha az üresen hagyott mintegy harminc lapot kitevő helyre odaférne akár a könyvecske teljes adaptációja is, a füzet e rövid, vélhetőleg mnemotechnikai érdekű (szolgai) feldolgozásokból mindösszesen harminchármat tartalmaz. ${ }^{534}$ Köztük az idézett szentenciáét:

\footnotetext{
Ne higgy mindenkor az asszonyállatnak,

Jámbor szolgákra, ha panaszolkodnak,

Nem is kell helt adni kívánságoknak,

Mert kit ura szeret, azon ki is adnak.
}

Egy másik füzetben tizenkét „catói” aranyigazságnak készíti el megint hosszabb, 4-13 strófányi parafrázisát. ${ }^{535}$ Ezek sorrendjében már semmiféle koncepciózusság nem fedezhető fel. A bemásolás viszont valamiért megint csak félbemarad, s az adott fizikai egység második felét kitevő tizenöt lapra később részben bizonytalan eredetű, vegyes témájú szöveganyag kerül. $^{536}$

A hosszabb parafrázisok közül az egyik (Ne higgy mindenkor az asszonyállatnak...) szintén az I. könyv 8. disztichonja alapján készült. ${ }^{537}$ Terjedelmében ez 10 strófát számol. Ugyancsak ennyit tesz ki Madáchnak az a valamikor különálló, az imént említett füzethez

\footnotetext{
${ }^{531}$ Libellus elegantissimus, A5v. (I. könyv, 8. tétel.)

532 A mikrokorpusz geneziséről 1. RMKT XVII/12, 723. és 726-729. Meglátásom szerint a leszármazás megállapítása kikezdhető ugyan, de annak cáfolatára magam is csak hasonlóképpen bizonytalan hipotéziseket tudnék szolgálni.

${ }^{533}$ Madách-Rimay-kódexek, I, 77-128.

${ }^{534}$ Uo. Kritikai kiadását 1. RMKT XVII/12, 34

${ }^{535}$ Madách-Rimay-kódexek, II, 1-36.

${ }^{536}$ Uo. Erre a szövegcsoportra a későbbiekben visszatérek.

${ }^{537}$ Uo. Kritikai kiadását 1. RMKT XVII/12, 22/I. sz.
} 
utólag illesztett levél rektójára írott, a rossz feleséget ostorozó verse. ${ }^{538}$ A levél beragasztását nyilván az indokolja, hogy a parafrázisnak és az asszonycsúfolónak nyolc versszaka - apróbb változtatásoktól eltekintve - megegyezik. A jobb áttekinthetőség kedvéért a szövegeket teljes terjedelmükben közlöm:

Nil temere uxori de servo crede querenti Az gonosz asszonyállatról ${ }^{540}$

Saepe enim muier quem coniunx diligit odit ${ }^{539}$

1. Ne higgy mindenkor az asszonyállatnak, Jámbor szolgákra ha panaszolkodnak, Nem is kell helt adni kivánságoknak, Hogy igaz szolgáját érte megunnák.

2. Az asszonyállat azt nem kedveli, Melyet az férje leginkább szereti, Mindenkor az ellen haragját neveli, $S$ végre férjét is érte meggyülöli.

3. E világon vad s gonoszabb állatoknál, Asszonyállatoknak kegyetlen haragnál, Nem is mondhatnál mérgesebbet annál, Mikor megbúsul, haraggal elötted áll.

4. Asszonyállatoknak csudás ö elméjek, Mint lassú viznek tekergös örvények, Magokban eloszló harag hozó mérgek, Ne csudáld, hogy halvány miattok az férjek.

5. Férjének nem nézik az ö becsületit, Ha látja jönie kedves jó vendégit, Mindenben mutatja böcstelenségit, Morogva készíti minden fözelékit.

6. Asszony, ha haragszik, mérgében reszket, Akkoron gonoszság sziviben ver fészket, Átkozza és szidja az nyavalyás férjét, Kivánja szegénynek egy órában vesztét.

7. Hogyha neki tisztességhez férne, Búsult állapatban tudja, mit cselekedne, Ha férjének élte sinóron lehetne, Haragjában ö mindjárt elmetszene.

8. Nem ok nélkül mondja Salamon könyviben, Férfiat ezer közül talált az seregben,

De tökéletes asszonyállatot egyet sem, Ki természetiben volna, mint az napfény.

9. Némely asszonyállatok tisztességkivánók, Cifrázásokban mód nélkül valók, Szerelmeskedésben igen bemerülök,

1. Asszonyállat, ha haragszik, ugyan reszket, Akkoron gonoszság szíviben ver fészket, Átkozza, szidja nyavalyást férjét, Kivánja szegénynek egy órában vesztét.

2. Asszonyállat azt nem kedveli, Melyet férje leginkább szereti, Mindenkor az ellen haragját neveli, Végre férjét is érte meggyülöli.

3. Világon vad, gonoszabb asszonyállatoknál, Asszonyállatoknak kegyetlen haragnál, Nem is mondhatsz mérgesebbet annál, Mikor megbúsul, haraggal melletted áll.

4. Asszonyállatoknak csudás elméjek, Mint lassú víznek tekergös örvények, Magokban eloszló haragos mérgek, Ne csudáld, hogy halvány miattok férjek.

5. Férjének nem nézik ö becsületit, Ha látja jönie kedves vendégit, Mindenben mutatja böcstelenségit, Morogva készíti ö fözelékit.

6. Hogyha nekik tisztességhez férne, Búsult állapatban tudja, mit cselekedne, Ha férjének élte sinóron lehetne, Haragjában azt mindjárt elmetszene.

7. Nem ok nélkül mondja Salamon könyvében, Férfiat ezer közül talált az seregben, De tökéletes asszonyállatot egyet sem, Ki természetiben lenne, mint a napfény.

8. Nem gondol urával, széllelfutos, Noha kis subája prémes és nyusztos, Esö vítöl pegyvet süvege lustos, Főkötôje leesett, haja csuportos.

9. Rágalmazza asszonyállat szomszédit, Dicsíri magához hasonló követöit, Urára morog, hogy nem készíti étkit, 
Ne csudáld, hogy bomlik farokon az hámjok.

10. Jámbor s tökéletes asszonyemberek

Magokra ez verseket ne terjesszék,

De söt, ez verseket nagyra becsüljék,

Csak gonosz asszonyállatok erkölcsére értsék.
Melyre híhassa koslató barátit.

10. Felette való tisztesség kívánó,

Morgolódó, mód nélkül való,

Kényességében igen bemerülö,

Az farán hámja igen lecsüggö.

A parafrázis, látjuk, nem tartalmazza a csúfoló szarkasztikus bővítését szolgáló 8. és 9. versszakot. A csúfolóból viszont hiányzik a parafrázis első és utolsó (vagyis 10.) szakasza. A nyitóstrófát ebben egy olyan szakasz képezi, mely az előbbi főváltozatban is megtalálható (6. vsz.); csakhogy ezzel a cserével nemcsak a beszédnem változik meg (lévén az írásmü célja dissuasio helyett immáron vituperatio lesz), de a vers valamelyest el is távolodik az eredeti szentencia értelmétől, hiszen a 2. (és ilyenformán első közös) versszak önmagában csak a disztichon második sorát fejti ki. A parafrázis zárlatát a kevés kivételnek, vagyis a jó asszonyoknak szánja. Ez a csúfolóból azért maradhat ki, mert a hordozója fonákján olvasható - mintegy párversekként - a közös Jó asszonyállatról cím alatt két ének. ${ }^{541}$ (Ez a levélnyi egység tehát eredetileg nem volt része a füzetnek.) Öket mint lehetséges hallgatóságot ezúttal tehát nem szükséges a megfeddettekkel egy lapon megszólítania.

A parafrázis elhagyott strófáit a fentiek értelmében tehát nemigen nevezhetjük egyedinek: az első egy szentencia (tömörebben másutt önállóan is megálló) átalakítása, az utolsó pedig egy formulaszerü toldalék. Ugyanakkor a csúfoló saját versszakairól is el lehet mondani, hogy azok állandósága viszonylagos: jellegzetes fordulataik az életmü további elemeivel mutatnak intratextuális kapcsolatot. A házasságtörőkre jellemzőnek tartott csuportos (é. borzas, kócos) haj motívuma megjelenik a paráznaságról szóló traktátus egy betétversében is, ${ }^{542}$ ahogy az oximoron értékủ koslató asszony is a Bendö Panna énekében - s tegyük hozzá, e két alkotás egyként hasonlítja a bujálkodók természetét a disznóéhoz.

\footnotetext{
${ }^{541}$ Ezek: Nagy Isten ajándéka... (RMKT XVII/12, 35. sz.); Asszonyembernek szemérmetessége... (RMKT XVII/12, 36 sz.). Elöbbi esetében a rövidebb változat - mert Madách ezt is kétszer jegyezte le: egy ízben itt (Madách-Rimay-kódexek, II, 3v), két strófányi terjedelemben, Majd a füzet autentikus egységén belül is (Madách-Rimay-kódexek, II, 15r), kiegészítve egy harmadik strófával, melyben a részeges feleséget mint isteni büntetést ábrázolja. Az amplificatio oka itt is az ellenvers hiánya lehet. A szövegközléstől terjedelmi okokból eltekintek, ugyanakkor megjegyezném: e néhány laudatív strófából is kitűnik, hogy Madách a női szépséget kizárólagosan etikai szempontoknak alárendelve képes értékelni. A költői képek forrása, ahogy arra Varga Imre is figyelmeztet, Sirák fia könyvének 26. fejezete. (Vö. RMKT XVII/12, 729.)

${ }^{542}$ Mint azt Varga Imre megállapította, Szent Jeromos alábbi passzusa örvén: „, Quidam luxuria faetidi, ut turpissimae sues sunt deturpati. ” Vö. RMKT XVII/12, 705, 713.
} 
A füzetben e verseket a Libellus elegantissimus egy tematikailag rokon tanításának úgyszintén 10 strófás részletezése követi. ${ }^{543}$ A tárgyi hasonlóságban rejlő lehetőség nem is marad kiaknázatlanul: a kolligátumok korábban említett részében, közvetlenül a strófányi terjedelemben fordított disztichonok sora előtt egy, a két parafrázis strófáinak kontaminációjából álló versezet olvasható. A szövegeket ezúttal is teljes terjedelmükben közlöm:

Uxorem fuge ne ducas sub nomine dotis ${ }^{544}$

1. Felesíget ne végy magadnak jószágért, Sem penig drága fris aranyas ruháért. Szeressed asszonyállatot jó erkölcséért, Szemérmes jámbor tökéletességéért.

2. Ki jószágért veszen asszonyállatot, El kell szenvedni morgolódásokot, Békével nem türhetik együttlakásokat, S gyakran pálca is kenegeti hátokat.

3. Afféle embernek étele sem esik jól, Mikor felesége haraggal dudol, Noha tetteti az férje s neki szépen szól, De azért mérge testiben széllel oszol.

4. Szemire hányja mindennapi költségét, Hogy sokat költ, hozzá nem keres többet, Izzasztja, erölteti szegínnek az fejét, Elöle kiüzi, nem szánja az vesztét.

5. Jobb efféle házasságot elkerülni, Egész életében nötelenül lenni,

Hogy sem ez világon búbánattal élni, S gazdag asszonyállattal magát kötelezni.

6. Boldog Isten, kik sokan vadnak effélék, Kiknek nyakokon vadnak illyen kötelek, Nagy háborúság miatt elvész az eszek, Mert egész éltekben nem békességesek.

7. Az olyan embernek nincs gyönyörüsége, Élete folytában nagy keserüsége,

Feleségének ha jut gonosz erkölcse eszébe, Mindjárást nagy bánat érkezik szivibe.

8. Noha tetteti felesége elött, hogy örül, De szemével gyakran reája kakucsol, Ha látja, hogy bortúl orcája pirosul, Vigságát elhagyja, féltében melléje ül.

9. Szegény alázatost jobb feleségül venni, Jó erkölcsén gyönyörködvén nyugodni, Hogysem nagykonyhájú asszonyt csókolni, Hatlovó szekéren nagy suhajtozván ülni.

10. Ilyennel az Isten jobban megáld, $S$ csendes élettel tégedet meglát, Búbánattúl éltedet távoztat,

Uxorem fuge ne ducas sub nomine dotis ${ }^{545}$

1. Feleséget ne végy magadnak jószágért, Sem penig pénzért s aranyas ruháért, Szeressed csak ötet drága jó erkölcsért, Szemérmes jámbor tökéletességért.

2. Ki jószágért veszen asszonyállatot, El kell szenvedni morgolódásokot, Nem türhetik azok együttlakásokot, Ha szintén pálca is üti az hátokot.

3. Mit az ura végez, azt visszacsúfolja, Emberek elött vele visszahazutolja, Ha becsületi vész, azt ö nem gondolja, Csak bosszúját urán tölthesse s torolja.

4. Dúl-fúl ö magában, soha nincsen kedve, Ha az férje elkölt ládából pénzébe, Mindenkor morgódik nyavalyás férjére, Akarván tánirt is hajitani fejére.

5. Szemire hányja mindennapi költségét, Hogy sokat költ s hozzá nem keres többet, Izzasztja s fárasztja gonddal ö elméjét, Elöle kiüzvén, nem szánván ö vesztit.

6. Férjének nem nézi az ö becsületit, Ha látja jönie férje jó vendégit, Mindenkor mutatja ö böcstelenségit, Morogva késziti minden fözelékit.

7. Azon asszonyállat nem mutatja kedvét, Melyet az férje leginkábblan szeret, Haragját neveli az ellen, ha lehet, $S$ végre férjét is mással is gyülöltet.

8. Mert ha haragszik, mérgében ö reszket, Akkoron gonoszság sziviben ver fészket, Átkozza és szidja az nyavalyás férjét, Kivánja szegénnek egy órában vesztét.

9. Hogyha nekije tisztességhez férne, Búsult állapatban ö mit cselekedne, Ha férjének élte sinóron lehetne, Haragjában ö azt mindjárt elmetszene.

10. Afféle embernek étele sem esik jól, Mikor felesége haraggal dudol,

Noha tetteti férje és neki szépen szól,
11. Jobb ily házasságot neki elkerülni, Egész életében nötelenül lenni, Hogysem ez világon búbánattal élni, S gazdag asszonnyal magát kötelezni.

12. El kell nekije mindeneket türni, Ha pénzében akar valamit költeni, Feketét fejérnek kell mindent mondani. Járomban ha fogja nyakát ott tartani.

13. Hire nélkül nem mer szomszédjához menni, Mindjárt másokhoz tudja ö toldani, Böcstelenséggel fogja ö illetni, Azhon akaratja, ott kell neki ülni.

14. Boldog Isten, ki sokan vadnak effélék, Kiknek nyakokon vadnak ily kötelek,

Nagy háborúság miatt elvész az eszek, Mert egész éltekben nem békességesek.

15. Az olyan férfinak nincs gyönyörüsége, Élete folytában nagy keserüsége,

Felesége ha jut s gonosz volta eszébe, Mindjárt az bánat férkezik szivibe.

16. Felesége körül tetteti hogy örül, De szemiben gyakran, ha lehet, kakucsol, Ha látja, bortúl orcája pirosul, Vigságát elhagyja, féltében melléje ül.

17. Dicsiri, hogy nem volt szebb s jobb felesége, Elöbb felesígit ócsárlja elötte,

Emeli az pohárt, csókolja féltébe,

Ö mint oroszlány ül neki ölébe.

18. Ifjaknak özvegyet jobb feleségül venni, Jó csendes erkölcsén gyönyörködvén nyugodni, Hogysem nagykonyhájú szépasszonyt csókolni, Hatlovó szekéren suhajtozván ülni.

19. Keress te magadnak csendes, jó leányzót, Ne nézz nagy cifrára [!] jószágó gazdagot, Ha szelid és jámbor, mindent megtalálsz ott, Megáld az Isten mindennel házadot.

\footnotetext{
${ }^{543}$ Az említett disztichon a következő: ,, Uxorem fuge ne ducas sub nomine dotis, / Nec retinere velis, si coeperit esse molesta." Libellus elegantissimus, B6r. (III. könyv, 12. tétel.).

${ }^{544}$ Kritikai kiadása: RMKT XVII/12, 23/II. sz.

${ }^{545}$ Kritikai kiadása: RMKT XVII/12, 23/I. sz.
} 
Erről az összetett (iuncta) terjedelmü házassági tanácsadó költeményről tehát az állapítható meg, hogy bő kétharmada reciklált elemekből áll, hiszen csak hat olyan strófát számlál, amely nem jelenik meg a többi variáns valamelyikében. ${ }^{546}$ Ráadásul Madách Invidia c. rövid allegorikus verse, mely a kódexek jelenlegi formájától is független, a főbünök és erények emblémaszerű katalógusát tartalmazó lapíven (az ún. Sajókazai-kódex III. néven ${ }^{547}$ ) őrződött meg, második szakaszának az elején szintén az egyik ilyen vándorstrófa szóanyagából építkezik. $^{548}$

Vegyük észre ugyanakkor, hogy egy-egy téma többszöri kidolgozása rendre különböző verstípusokban valósul meg; a szövegek újrahasznosításának motivációja ilyeténképpen tehát mindig a megváltozott alkalomban érhető tetten. Vagyis noha a vizsgált korpuszhoz minden kétséget kizáróan rendelhetjük hozzá Madách Gáspár szerzői nevét, az a szövegfelfogás, melyet az életmü itt tárgyalt szegmense látszik tükrözni, jobbára mégis a közköltészeti gyakorlathoz fogható.

\section{2. Madách mint latrikánus versek szerzője}

\section{2. 1. „Kurvák}

A Madách Gáspár kézírásában fennmaradt egyik legismertebb költemény, melynek attribúciója tehát bő félszázada billeg, a Bendő Panna komáromi asszony éneke címü alkotás. ${ }^{550}$ A szerzőség megállapítását ez esetben a szöveg rendeltetése is nehezíti - mert a jól sikerült kurvacsúfoló, legyen bár térben, időben és tárgyában behatárolt, sehogy nem nyújthat biztos fogódzót a kiéneklő azonosításához. ${ }^{551}$ Ezzel szoros összefüggésben a vers a

\footnotetext{
${ }^{546}$ A 3., 4., 12., 13., 17. és a 19. versszakok.

${ }^{547}$ Vö. JANKOVICS, ,, Akadtam egy picturára..., 38.

548 „Irigység emberben felette nagy vétek, / Mikoron sziviben irigység ver fészket, / Fonnyasztja, apasztja az nyavalyás testét, / Jó szerencséjének kívánja elvesztét...”. (RMKT XVII/12, 18. sz., 7-10. sor) Vö. RMKT XVII/12, 22/I. sz., 8. vsz.; RMKT XVII/12, 22/II sz., 1. vsz., RMKT XVII/12, 23/I. sz., 8. vsz. Mindez Varga Imre elött sem ismeretlen; vö. RMKT XVII/12, 723.

${ }^{549} \mathrm{Az}$ alfejezet címét a már idézett, Stoll Béla válogatta Pajkos énekek c. antológiából kölcsönöztem, a vonatkozó tematikus rész éléről. L. ott.

${ }^{550} \mathrm{Az}$ ének nagyobb népszerüsége egyben könnyü hozzáférést is eredményez, ezért közreadásától itt eltekintek. Kritikai kiadása: RMKT XVII/12, 41.

551 Vö. PAP, A sólyom szíve, 49-53. Bendő Panna kilétét illetően Szentmártoni Szabó Géza hívta fel a figyelmemet az alábbi tanulmányra: TAKÁTS Sándor, A komáromi péntökösök $=\mathrm{T}$. S., Müvelödéstörténeti tanulmányok a XVI-XVII. századból, s. a. r. BENDA Kálmán, Bp., Gondolat, 1961 (Nemzeti Könyvtár), $286-295$.
} 
legsablonosabb elemekből áll össze, forrásvidéke is csak hozzávetőlegesen deríthető föl, az alábbiak szerint.

A Vásárhelyi Daloskönyvböl ismert a Tudod-e, miért jöttem elédben? kezdősorú ének, melynek beszélője épp a Bendő Pannáéhoz hasonló körülményeiről számol be. ${ }^{552}$ Miután férje elutazott, arany ékszereket vesz magára, drága holmikba: selyembe, prémbe, kamukába (!) öltözik, és a nőstényszarvaséhoz hasonló szerelmes kedvében napestig keresi szeretőjét az utcákon, hogy elvezesse a kedvére feldíszített ágyasházába. Ezek a toposzok - mint azt Stoll Béla kimutatta - egészen Salamon könyvének hetedik részéig vezethetők vissza. ${ }^{553}$ Hogy az ének női dalból csúfolóvá váljék, néhány részletét meg kell változtatni. A komáromi serfőzőnét nem beszéltetni kell, hanem ahogy a versben is áll: tükröt tartani neki. Szerelmes kedvét pedig nem a szarvasünőéhez hasonlítani (lévén az mégiscsak nemes vad), hanem alantas jószágokhoz (kutyához és disznóhoz), és így tovább.

Az a népszerü toposz viszont, miszerint a nők nem tartoznak az értelemmel felruházott teremtmények közé, hanem hitvány állatoktól (többek között kutyától és disznótól) származnak, legalábbis Szémónidésztől ismert. ${ }^{554}$ A szémónidészi jegyzéknek a XVII. században a legelterjedtebb forrása Buchanan latin fordítása volt, ennek pedig létezik egy 1627-re datált magyar nyelvű parafrázisa, amely történetesen a Tükör címet viseli. ${ }^{55}$ Bár töredékesen maradt fenn, megállapítható, névtelen szerzője mintegy ötszörösére bővíti eredetijét. ${ }^{556} \mathrm{Az}$ amplificatiót az asszonyok rossz szokásainak és tulajdonságainak olyan kevéssé intellektuális közhelyei teszik ki, melyek csak igen nagyvonalúan vezethetők vissza Szémónidészig, ugyanakkor az irodalom alatti regiszterekben a legáltalánosabban elterjedtnek mutatkoznak. Ezek közül néhány megjelenik a Bendő Panna énekében is. Madách moralizáló Cato-parafrázisai viszont szinte a teljes apparátust fölvonultatják.

A szövegben a fentiek mellett azonban kitapintható egy aprócska Rimayreminiszcencia is:

Lelkemen peniglen rút fekély fokadott, $S$ arra nem fül elmém, jóban olly akadott... ${ }^{557}$
Belöl az testedre rút fekély fakadott, Ragadó bojtorján ruhádra akadott... ${ }^{558}$

\footnotetext{
${ }^{552}$ RMKT XVII/3, 301. (185/I. sz.)

${ }^{553}$ Vö. RMKT XVII/3, 639.

${ }^{554}$ Vö. Görög költők antológiája, szerk. SZEPESSY Tibor, Bp., Európa, 1982 (A Világirodalom Klasszikusai), 93-97.

${ }^{55}$ Régi Magyar Költök Tára, XVII. század, 8, Bethlen Gábor korának költészete, s. a. r. KOMLOVSZKI Tibor, STOLL Béla, Bp., Akadémiai, 1976 (a továbbiakban: RMKT XVII/8), 299-305. (107. sz.)

${ }^{556}$ Vö. RMKT XVII/8, 586-588.

557 Ó, ki késön futok..., 7-8. sor. Kritikai kiadása: RÖM, 44. sz.

558 Bendö Panna komáromi asszony éneke, 6-7. sor.
} 
Csakhogy ez a szerzőséget illetően legfeljebb arra enged következtetni, hogy az ének nem maradt érintetlen Rimay valamely olvasójának (engedjük meg: akár Madách Gáspárnak) a hatásától.

A Madách-Rimay-kódexek leírása több tanulmányban és kritikai kiadásban is napvilágot látott, a versek sorrendje mégis csak a legritkább esetben tételeződik érvként az attribúció körüli diskurzusban. ${ }^{559}$ Mint azt már korábban említettem, Madách a Cato-parafrázisok után további két helyen tisztázott verseket a füzetbe. Az egyik szövegcsoportot szinte folytatólagosan, egy levél kihagyásával jegyezte le: ide kerültek a Szodomához hasonló paráznák hajléka... (10r), az Ó, Jehova, szent Istenem... (10v) és az Ó, csalárd világ, mit cselekeszel... (12r) kezdősorú énekek. ${ }^{560}$ A másikat a füzet utolsó lapjaira írta. Itt található a Pöngését koboznak gyakran, ha te hallod... (16r) incipitü vers, ill. a Balassa János éneke sólymocskájárúl (16v) és Bendö Panna komáromi asszony éneke (17r). ${ }^{561}$

Az első csoport darabjaitól nemigen szokás elvitatni Madách szerzőségét. Nem úgy a füzetvégi blokk költeményei esetében. A Pöngését koboznak... kezdetü versről Varga Imre gyanúja nyomán Bitskey István bizonyította, hogy az nem lehet Madách szerzeménye, ${ }^{562}$ a Balassa János énekével kapcsolatban pedig Jankovics József vetette föl, hogy az - ahogy akkor gondolta: szemben a Bendő Panna énekével - erősen kilóg az életmüből. ${ }^{563}$ Jankovics meglátása szerint ti. „Madách hitelesithető irásai mindegyikében [...] a bünt és a bünös embert ostorozó morális fensőbbség nevében és alakjában fog tollat. "564 márpedig a Bendö Panna éneke „nem túlfütött erotikájú, hijával van minden rejtett allúziónak, nehezen felfejthető ezoterikus utalásnak", ${ }^{565}$ ezért az összes trágárságával együtt megfelel Madách általános erkölcsjavító szándékának - ami éppen nem igaz a sólymocskás versre. Legutóbb aztán (a MAMÜL vonatkozó cikkében) lényegében revokálta mindezt. Most úgy tartja, hogy e kettőről egyként feltételezhető, hogy „durvaságuk miatt vlsz. nem tartoznak az ájtatos hangvételü, magas erkölcsiséget és erös vallásosságot tükrözö életmübe. „566

\footnotetext{
${ }^{559}$ RÖM, 162-166.; VARGA, Tallózások Madách Gáspár körül, 69.; RMKT XVII/12, 663-665.

${ }^{560}$ A 11 sz., valamikor különálló levél, rektóján az $O$, csalárd világ... egy variánsával szintén utólag lett beillesztve a füzetbe.

${ }^{561}$ Nem számoltam ide az egy későbbi időpontban, halvány tintával a füzet $15 \mathrm{r}$ lapjára (vagyis közvetlenül a Pöngését koboznak... elé) bemásolt Nagy Isten ajándéka... kezdetü ének három strófás variánsát.

${ }^{562}$ VARGA, Tallózások Madách Gáspár körül, 69.; BITSKEY, Pöngését koboznak..., 225-234.

563 JANKOVICs József, A Madách Gáspár-jelenség, 50.

${ }^{564}$ Uo., 53.

${ }^{565}$ Uo., 54.

${ }^{566}$ Magyar müvelödéstörténeti lexikon: Középkor és kora újkor, VII, föszerk. KÖSZEGHY Péter, szerk. TAMÁS Zsuzsanna, Bp., Balassi, 2007, 133.
} 
A magam részéről a Bendő Panna éneke szerzőségének ügyében sosem tudtam állást foglalni. Egyrészt azért, mert (számomra legalábbis) megfoghatatlan, hogy a szöveg mennyiben viseli magán Madách Gáspár keze nyomát. Másrészt pedig azért, mert a szerző fogalmát az adott esetben - illusztris közköltészeti alkotás egy eminens alkalmi költő repertoárjában - eleve nem tartom feltétlenül érvényesnek. ${ }^{567}$ Azt ugyanakkor, hogy maga a költő miként tekintett a versre, talán jelezheti a kompozíció is. Megismétlem: a Bendő Panna éneke a kódex egyik legvaskosabb füzetének utolsó levelén olvasható, közvetlenül a Pöngését koboznak... kezdetü versike és a Balassa János éneke után, azok előtt pedig van összesen hét üresen maradt lap.

Fogadjuk el Jankovics véleményét: a Balassa János éneke túlságosan rafináltnak, a Bendö Panna éneke viszont túlságosan explicitnek bizonyul a hitelesnek tekinthető Madáchversek retorikai eszményéhez képest. Ez esetben arra a kérdésre kell választ találnunk, vajon mi okból jegyzi le azokat mégis a költő.

\section{2. 2. „Latrok ${ }^{, 568}$}

A Bendő Panna énekével mint kurvacsúfolóval és a Balassa János énekével mint a kurvázó férfi beszédével Gerézdi Rabán e tárgyban írott vehemens értelmezése nyomán szokás verspárokként számolni. ${ }^{569}$ A Szodomához hasonló... kezdetü alkotás és a Balassa János éneke tartalmi és stiláris hasonlóságaira azonban csak Varga Imre figyelt fel, aki a kapcsolódó levéltári anyag egy figyelemreméltó részletében találta meg a Balassa János éneke és a Szodomához hasonló... kezdetű lehetséges közös kontextusát. ${ }^{570}$ Röviden összefoglalva: Madách Gáspár egy időben Balassa Simonnak volt a kékkői prefektusa. Simon Balassa (III.) Zsigmondnak volt a fia. Zsigmond halála (1623) után az örökösök elhúzódó pereskedésbe fogtak egymással. Madách tehát Simon érdekeit volt hivatott képviselni a többiekkel - köztük annak fiatalabb öccsével, a vádaskodás során egyebek mellett feslett erkölcsűnek is titulált Balassa Jánossal - szemben. A Balassa János éneke szerzőségének kérdésében Varga ezt a körülményt egyértelműen Madách javára tudja be. A szövegeket most is érdemesnek tartom teljes terjedelemben közölni:

\footnotetext{
${ }^{567}$ Noha ellenkező esetben a verset úgy annotálhatnánk, mint a régi magyar költészet történetének egyetlen, szerzővel rendelkező kurvacsúfolóját; vö. Pajkos énekek.

${ }^{568}$ Vö. 549. lábjegyzet.

${ }^{569}$ GERÉZDI, ,,Balassa János éneke solymocskájárul”, 689-695.

${ }^{570}$ VARGA, Tallózások Madách Gáspár körül, 72-73.
} 
1. Az én sólymocskám Palojtán vagyon, Sziviben szerelmem nö igen nagyon, Belöle ikrája foly igen lágyon,

Kit drága kenetül magamnak tartom.

2. Gondolkodván érte nem tudok, s mind állok,

Ha eszemben jut, csaknem meghalok,

Szerelmiért Palojtára gyalog ballagok,

Mint ész nélkül szükös járó bolondok.

3. Mikor hozzá megyek, elmosolyodik, Elömben jövén ö felfosztozik,

Okulárját mutatván szemem tisztittatik,

Ragyadó szerelme szivembe férkezik.

4. Ó, én sólymocskám, ha közelben laknál,

Kékköi kapun hozzám bejárhatnál.

Sokjót is nálam gyakran találhatnál,

Megtölteném begyedet, kit azután látnál.

5. Az én kezemre tégedet vennélek,

Szép nyoszolyámra mellém fektetnélek,

Karjaimmal gyakran téged ölelnélek,

Végre mint az nyúl, által is szöknélek.

6. Noha kezemen vagyon apertúra,

Mely szemeimet genyetbül tisztitja,

De ha sólymocskámnak rám fordul az fara,

Mindjárt szemeimnek megjün szép világa.
1. Szodomához hasonló paráznák hajléka, ${ }^{572}$

Kleopátrának szép ékes barlangja,

Szemiramisz asszonynak lakó hazája,

Fertelmességnek tanuló oskolája.

2. Bujaság, torkosság tebenned lakik,

Paráznaság töled el nem távozik,

Az az jó benned, ki igen iszik,

Csóknak izivel ha böven telik.

3.Minden rossz gaz erkölcs tebenned vagyon,

Tökéletlenség benned nö nagyon,

Hazugságnak akla, hivatol, mondom,

Állhatatlanságnak fészke nagy vagyon.

4. Latorságnak fiai benned lakosznak,

Kik csak örülnek az tolvajlásnak,

Tágulása nincsen az sok lopásnak,

Fiaid merülnek nagy prédálásnak.

5. Az az jó tebenned, ki nagyot hazudhat,

Azki nem volt soha, olyant is mondhat,

Jámborok szava nálad semmit nem hat,

Mert szitkos voltoddal nyelveket gázoltat.

6. Istentelenségben merülö úrfiak,

Paráznaságra hajlandók, mint az vak,

Nem nézvén, hogy közel való atyafiak,

Csak ök büzölhessék odóját, mint az bak.
7. Atyafiúságnak benned nagy romlása,

Fertelmességböl benned bomlása,

Atyafiak között való rút ágyasa,

Egyik mint másik kútját úgy ássa.

8. Asszonyok nem nézik benned, hogy atyafiak, Egy méhböl való származandottak,

Sem igaz kötelit az házasságnak,

Fékemlőit eresztik paráznaságnak.

9. Ó, te parázna nöstín matéria,

Mely szivedet bünnel az ördög marja,

Ne nézz az feslett erkölcsnek katonáira,

Tekints, gondolkodjál pokol kínaira.

10. Térj ki immár az sok fertelmességbül, Mélységes nagy viznek forgó örvényiböl, Ne igyál immár bujaság mételébül,

Szabadits meg magadat ördögnek töribül.

11. Nem ilyen vala ezelött ez e Vár, Mikor benne lakott zöld publikán madár, Nem vett eröt akkor veres szemü hóhár, Mostan sok rossz lakja, felette nagy kár.

A két versnek valóban több olyan motívuma is van (a vár, a paráznaság, a szembaj, stb.), amely vitán felül hasonlít vagy megegyezik. Ebből azonban egyáltalán nem következik, hogy egyazon szerzőt kellene sejteni mögöttük. A Balassa János éneke ugyanis értékelhető olyan aenigmaként is, amelyben a szubjektum identitása - ahogy arra Szilasi László a költeményröl írott szép és fontos tanulmányában rámutatott - alapvetően képlékeny (vagyis a terminus bahtyini értelmében is parodisztikus): szinte sorról sorra felülíródik, ezért aztán a közlés tulajdonképpeni jelentése is rögzítetlenül marad. ${ }^{573}$ Márpedig - és ebben látom a bizonyságot arra, hogy a Szodomához hasonló... kezdetű szerzősége a Balassa János énekével szemben Madách Gáspárnak tulajdonítható - a költői nyelv ilyesfajta játékterét az autoritásokhoz erősen vonzódó Madách általában igyekszik szűkíteni. ${ }^{574}$

A két vers imitatív viszonya tehát indirekt módon is parallel a Tudod-e miért jöttem elédben ... kezdetü közköltészeti alkotás és a Bendő Panna éneke köztivel, amennyiben az első

\footnotetext{
${ }^{571}$ Kritikai kiadása: RMKT XVII/12, 41. sz.

${ }^{572}$ Kritikai kiadása: RMKT XVII/12, 39. sz.

${ }^{573}$ SZILASI, A nyúl és a sólyom, 258-269. A paródia bahtyini fogalmát Szilasi a vers kapcsán nem érinti. Vö. Mihail BAHTYIN, François Rabelais müvészete: a középkor és a reneszánsz népi kultúrája, ford. KÖNCZÖL Csaba, Bp., Osiris, 2002.

574 Erre a következö jelenség enged következtetni. A Madách-Rimay-kódexekben fennmaradt, ismeretlen szerzö(k)től származó tizenöt szerelmes ének közül az egyik így zárul: „,S kitöl lehet, kést is cseréljen hüvelyén.” (Szerelemtül csak kár ..., RMKT XVII/12, 47. sz.) A tetszetös képet Madách a paráznaságról írott traktátusának egy betétversében kölcsönzi el, ám annak jelentését egy jelzö segítségével igyekszik egyértelmüsíteni, ekképpen: „,Telhessék eleven késsel hivele. ”(RMKT XVII/12, 691.)
} 
személyben előadott bemutatás ezúttal is a tévelygőket gáncsoló vádbeszédre módosul. Ahogy ezt az alábbi áthallás is kiválóan tükrözi:

Az én sólymocskám Palojtán vagyon,

Szíviben szerelmem nö igen nagyon... ${ }^{575}$
Minden rossz gaz erkölcs tebenned vagyon, Tökéletlenség nö benned nagyon ... ${ }^{576}$

Ebből pedig az következik, hogy a Szodomához hasonló... kezdetű vers feltehetőleg a Balassa János éneke nyomán, de a Bendö Panna éneke mintájára készülhetett. Előbbi a retorikai anyagot (thema) szolgáltatta hozzá, az ügy (causa) kidolgozásának eszköztára azonban az utóbbiéval közös. A Szodomához hasonló... kezdetü vers a nevesítésnek az előzőekben megfigyelhető közös gyakorlatát ugyanakkor nem követi: Madách abban még a pozitív szereplőnek sem árulja el a valóságos nevét, csupán egy azóta is feloldatlan antonomázián keresztül jeleníti meg. ${ }^{577}$ Ami tökéletes összhangban áll azzal a sokat hangoztatott diplomáciai természetű meggyőződésével, hogy a meggondolatlan beszéd veszélyeztetheti a hivatali elömenetelt. ${ }^{578}$

Ez is lehet magyarázat arra, hogy miért emelődnek be a kérdéses versek a MadáchRimay-kódexekbe: mert azok többé-kevésbé olyan retorikai konstrukciókból állnak össze, amelyeknek Madách Gáspár szerette és értette a müködésmódját, és szívesen alakította azokat tovább kedvére és 17. századi költészeti anyagunk gazdagodására.

\section{3. Konklúzió}

Végezetül térjünk vissza a dolgozat e második részének kiindulópontjául vett idézethez. Amennyiben tehát Radvánszky Béla „elérés” és a „mérkőzés” terminusait mint az imitatio és az aemulatio magyar megfelelöit értjük, beláthatjuk, hogy ennek épp a fordítottja igaz. Mert amíg Rimay az örökül kapott eszközök továbbfejlesztésével valóban megkísérelt túllépni az elődön, addig Madách Gáspár a jelek szerint éppenséggel semmiféle hagyomány meghaladására nem törekedett.

\footnotetext{
${ }^{575}$ Balassa János éneke, 1-2. sor.

${ }^{576}$ Szodomához hasonló..., 9-10. sor.

577 A Zöld Pelikán kilétéröl ld. VARGA, Tallózások Madách Gáspár körül, 73.

${ }^{578}$ A verses életmüben többször kidolgozott gondolat egyik példája a Krónika c. vers 9. strófája: „,Mindazonáltal meg nem nevezem, / Ki legyen az, magam is szégyenlem, / Ha gyalázkodnék nevében s híriben, / Gátlása lenne előmenetelében.” Kritikai kiadása: RMKT XVII/12, 38/I. sz.
} 


\section{Bibliográfia}

A magyar irodalom története 1600-tól 1772-ig, szerk. KLANICZAY Tibor, Bp., Akadémiai, 1964.

A magyar nyelv szótára, I-VI, szerk. CZUCZOR Gergely, FOGARASI János, Bp., 1862-1874.

A magyar nyelv történeti-etimológiai szótára, I-IV, főszerk. BENKÖ Lóránd, Bp., Akadémiai, 1967-1984.

Ács Pál, Ratio és oratio: Rimay János verstipusai = Á. P., „Az idö ósága”: Történetiség és történetszemlélet a régi magyar irodalomban, Bp., Osiris/2000, 2001, 52-68.

Ács Pál, Rimay János korai versciklusai, ItK, 1989, 306-322.

B. KIS Attila, SzILASI László, Még egyszer a Pataki Névtelenröl: Történeti poétika és dekonstrukció, névtelenség és dialogicitás, ItK, 1992, 646-675.

Mihail BAHTYIN, François Rabelais müvészete: a középkor és a reneszánsz népi kultúrája, ford. KÖNCZÖL Csaba, Bp., Osiris, 2002.

Balassa Bálint és Zrínyi Miklós, s. a. r. SzÉCHY Károly, Franklin, 1905 (Magyar Remekírók, 1).

BALASSA Bálint minden munkái, kiad. DÉzSI Lajos, Bp., Genius, [1923], I-II.

[Balassi Bálint, Rimay János Istenes éneki], Lőcse, 1666, Brewer Sámuel.

Balassa Bálintnak istenes éneki, Bártfa, [1660k.], Klösz Jakab.

Balassa-kódex, fakszimile kiadás, kiad. KőSZEGHY Péter, betűhív átirat, kiad. VADAI István, Bp., Balassi, 1994.

BALASsi Bálint Összes müvei, kiad. EcKHARDT Sándor, I -II, Bp., Akadémiai, 1951-1955.

BALASsI Bálint Összes müvei, kiad. KÖSZEGHY Péter, Bp., Osiris, 2004 (Osiris Klasszikusok).

BALÁzS-HAJdu Péter, A romlás alakzatai: Adalékok Rimay János Tiszába esett könyvének tartalomjegyzékéhez $=$ Elözetes kérdések: Rohonyi Zoltán emlékkönyv, szerk. MILBACHER Róbert, Pécs, Kronosz, 2014, 25-32.

BALÁzS-HAJdu Péter, Panna bendője: Egy 17. századi kurvacsúfoló retorikai olvasata, Acta Historiae Litterarum Hungaricarum Tomus XXIX (Ötvös Péter Festschrift), 2006, 25-32.

BalÁzs-Hajdu Péter, Bognár Péter, Hevesi Andrea, Sinka Zsófia, Szegedi kísérlet a 17. századi magyar vers gépi feldolgozására = Filológia és textológia a régi magyar 
irodalomban, szerk. KECSKEMÉTI Gábor, TASI Réka, Miskolc, ME BTK Magyar Nyelv és Irodalomtudományi Intézet, 2012, 461-470.

BALÁzS-HAJdu Péter, JANKOviTs László, PAP Balázs, Apró madár hálóban? A Balassa-kódex első Rimay-verséröl = Septempunctata: Tanulmányok Petröczi Éva hatvanadik születésnapjára, szerk. PÉNZES Tiborc Szabolcs, Bp., rec.iti, 2011.

BARos Gyula, Rimay János szerelmi lyrája, BpSzle, 1906.

BÁN Imre, Az imitatio mint a reneszánsz arisztotelizmus esztétikai kategóriája = B. I., Költők, eszmék, korszakok, szerk. BITSKEY István, Debrecen, Kossuth Egyetemi Kiadó, 1997 (Csokonai Könyvtár, 11), 23-44.

BENE Sándor, Rimay Múzsája, ItK, 2011, 271-339.

Biblia: Ószövetségi és Újszövetségi Szentírás, s. a. r. RÓzSA Huba, Bp., Szent István Társulat, 2006.

BITSKEY István, Pöngését koboznak... = A régi magyar vers, szerk. KoMLOvszKI Tibor, Bp., Akadémiai, 1979 (Memoria Saeculorum Hungariae, 3), 225-234.

Bognár Péter, A régi magyar vers formatörténete a 16. század végéig, PhD-értekezés, Bp., 2012.

BóTA László, A Madách-Rimay-kódexek szerelmes versei, ItK, 1967, 1-24.

Cristoforo Castelletti, L'Amarilli, Vinegia, Giovanni Battista Sessa \& fratelli, 1587.

Jonathan CuLLER, Aposztrophé, ford. SzÉLES Csongor, Helikon, 2000, 370-389.

CSANDA Sándor, Balassi Bálint költészete és a közép európai reneszánsz stílus, Bratislava, Madách, 1973.

CSEHY Zoltán, Ámor végzetes kalandja Caeliával: Girolamo Angeriano Erotopaegnion címü kötetének viszonya a szerelmi dedikációs verskötetek korabeli konvencióihoz, Irodalmi Szemle, 2007/1, 9-21.

Paul DE MAN, Az olvasás allegóriái, ford. FogARASI György, Szeged, Ictus-JATE, 1999 (deKON-könyvek, 17).

ECKHARDT Sándor, A körmendi Balassa-emlékek, EPhK 1943, 26-48

ECKHARDT Sándor, A régi magyar költök képei = E. S., Balassi-tanulmányok, Bp., Akadémiai, 1972 (Irodalomtörténeti könyvtár, 27), 309-324.

ECKHARDT Sándor, Balassi Bálint irodalmi mintái, ItK, 1913, 171-192, 405-450.

Epicédium a Balassi fivérek, Bálint és Ferenc halálára, s. a. r. Ács Pál, Bp., Balassi, 1994. 
Erdélyi Magyar Szótörténeti Tár, I-XIV, föszerk. SzABÓ T. Attila [I-VII.], VÁMSZER Márta [VIII-XI.], KósA Ferenc [XII.], FAZAKAS Emese [XIII-XIV.], Bukarest, Kriterion [I-IV.], Bukarest-Bp., Kriterion-Akadémiai [V-VIII.], Bp.-Kolozsvár, Akadémiai-Erdélyi MúzeumEgyesület [IX-XII.], Kolozsvár, Erdélyi Múzeum-Egyesület [XIII-XIV.], 1975-2014.

Eurialus és Lucretia históriája = Régi Magyar Költök Tára, IX: XVI. századbeli magyar költők müvei, 1567-1577, szerk. VARJAS Béla, Bp. Akadémiai, 1990.

Fanchali Jób-kódex, MTAK A 280/3.

FERENCZi Zoltán, Rimay János, Bp., Athenaeum, 1911 (Magyar Történeti Életrajzok).

Marsilio FicInO, Commentarium [I], ford. IMREGH Mónika, Pompeji, 1993/1-2, 221-245.

Alan Dean Foster, Transformers: A múlt árnyai, ford. NovÁK Gábor, Debrecen, Gold Book, 2007.

Formulae puerilium colloquiorum, Dicta graciae sapientum, Libellus elegantissimus, Civitas morum, a fakszimile szövegét közzéteszi KöSZEGHY Péter, tan. BITSKEY István, Bp., Balassi MTA ITI -OSZK, 2007 (Bibliotheca Hungarica Antiqua, XL).

Northrop FRYE, A kritika anatómiája, ford. SzILI József, Bp., Helikon, 1998,

G. CzIntos Emese, A szerelem retorikája: A levélmüfaj alakváltozatai az Eurialus és Lucretiában $=A$ történetmondás rétegei a kora újkorban, szerk. GÁBOR Csilla, Kolozsvár, Scientia, 2005, 141-171.

GERÉZDI Rabán, „Balassa János éneke solymocskájárul”, ItK, 1965, 689-693.

Görög költök antológiája, szerk. SZEPESSY Tibor, Bp., Európa, 1982 (A Világirodalom Klasszikusai)

Gyarmati BAlassi Bálint Énekei, kiad. KöSzeghy Péter, SzABÓ Géza, Bp., Szépirodalmi, 1986.

H. HUBERT Gabriella, A sajókazai Radvánszky-könyvtár története, Szeged, JATEPress, 1998.

H. HUBERT Gabriella, Radvánszky János kódexe (Stoll 127. sz.) = Ghesaurus: Tanulmányok Szentmártoni Szabó Géza hatvanadik születésnapjára, szerk. CsÖRSZ Rumen István, Bp., rec.iti, 2010, 401-410.

Hesperidák kertje: Az ibéri világ költészete, s. a. r. ANDRÁs László, Bp., Európa, 1971, I-II.

Quintus Horatius Flaccus Összes versei, szerk. BORZSÁK István, DEVECSERI Gábor, Bp., Corvina, 1961,

HoRVÁTH Iván, Balassi költészete történeti-poétikai megközelitésben, Bp., Akadémiai, 1982.

HORVÁTH Iván, Történeti rétegek a XVI. századi magyar metrumkincsben, ItK, 1989, 193205. 
HoRVÁTH Iván, TóTH Tünde, Rimay ifjúkori versgyüjteményének rekonstrukciója = Ámor, álom és mámor: A szerelem a régi magyar irodalomban és a szerelem ezredéves hazai kultúrtörténete, szerk. SzENTMÁRTONI SZABÓ Géza, Bp., Universitas, 2002, 457-467.

HoRváth János, A magyar irodalmi müveltség kezdetei = H. J. Irodalomtörténeti munkái, kiad. KorOMPAY H. János, KorOMPAY Klára, I, Bp., Osiris, 2005 (Osiris Klasszikusok), 477705 .

HoRVÁTH János, Hír három virágénekröl, = H. J. Irodalomtörténeti munkái, kiad. KOROMPAY H. János, KOROMPAY Klára, II, Bp., Osiris, 2006 (Osiris Klasszikusok), 517-527.

ILLÉSSY János, B. Balassi Bálint egy pöre, ItK, 1910, 193-197.

IMRE Ilma, Balassi Bálint hatása a XVII. század névtelen költöire (A Vásárhelyi daloskönyv alapján), Bp., [Franklin], 1930.

IMRE Mihály, Egy rímtoposz históriája (nép - szép - kép - ép ... tép), ItK, 1984, 399-426.

IMrE Samu, A Szabács viadala, Bp., Akadémiai, 1958 (Nyelvészeti Tanulmányok, 4).

JAKAB László, BÖLCSKEI András, Balassi-szótár, DE BTK Magyar Nyelvtudományi Tanszéke, Debrecen, 2000 (Számítógépes Nyelvtörténeti Adattár, 8).

JANKOVICS József, A Madách Gáspár-jelenség: Erotikus költészetünk regiszterei $=$ J. J., Ex occidente...: A 17. századi magyar irodalom európai kapcsolatai, Bp., Balassi, 1999 (Régi Magyar Könyvtár, Tanulmányok, 3), 48-59.

JANKovics József, „Akadtam egy picturára.” Rimay János és Madách Gáspár allegorikus versének képzömüvészeti vonatkozásai, ItK, 1982, 652-656.

JANKOVITS László, Rimay és a civakodó istenasszonyok = Mesterek és tanitványok: Tanulmányok a bölcsészettudományok területéröl, szerk. BöHM Gábor, FEDELES Tamás, Pécs, PTE BTK Tudományos Diákköri Tanácsa, 2014.

JANKOVITS László, Rimay János: Örülhetne szivem..., ItK, 2011, 246-255.

JANKOVITS László, Soliloquium és oratio Rimay egy versében (Ne csudáld szivemet...) = Stephanus Noster: Tanulmányok Bartók István 60. születésnapjára, szerk. JANKOVICS József, JANKOVITS László, SZILÁGYI Emőke Rita, ZÁSZKALICZKY Márton, Bp., reciti, 2015, 211-220.

JENEI Ferenc, A Balassi-hagyaték történetéhez, ItK, 1966, 190-197.

KIRÁLY Péter, A lantjáték Magyarországon a XV. századtól a XVII. század közepéig, Bp., Balassi, 1995, (Humanizmus és Reformáció, 22)

KISS Farkas Gábor, Rab és szolga = Ghesaurus: Tanulmányok Szentmártoni Szabó Géza hatvanadik születésnapjára, szerk. Csörsz Rumen István, Bp., rec.iti, 2010, 309-315. 
KlANICZAY Tibor, A meditativ költészet: a manierizmus reprezentativ müfaja $=\mathrm{K}$. T., Pallas magyar ivadékai, Bp., Szépirodalmi, 1985,124-128.

KLANICZAY Tibor, A reneszánsz válsága és a manierizmus, ItK, 1970, 419-450.

Klaniczay Tibor, A szerelem költöje $=\mathrm{K}$. T., Reneszánsz és barokk: Tanulmányok a régi magyar irodalomról, Bp., Szépirodalmi, 1961, 181-295.

KlanICZAy Tibor, Hozzászólás Balassi és Rimay verseinek kritikai kiadásához, MTA I. OK, 1957, 265-338.

KoCsIS Viktória, Honnan gyüjtögetnek a méhek? Adalékok a hagyomány felderitésére gróf Balassa Bálintnál = Mikro \& Makro: Fiatal kutatók konferenciája, szerk. LovAs Borbála, NÁDOR Zsófia, SZATMÁRI Áron, SzILÁGYI Emőke Rita, Bp., 2013. (Arianna, 6), 165-169.

KomlovszKi Tibor, A Balassi-vers karaktere, Bp., Balassi, 1992 (Régi Magyar Könyvtár: Tanulmányok, 1)

KovÁCs Sándor Iván, Egy rímtoposz diadalmenete, Újhold-évkönyv, 1988/1, 362-385.

Következnek gyarmati Balassa Bálintnak istenes éneki, Bécs, 1633, a fakszimile szövegét közzéteszi KőszEGHY Péter, Bp., Balassi, 1994 (Bibliotheca Hungarica Antiqua XXIX).

KÖSZEGHY Péter, A titokzatos SOLVIROGRAM, Korunk, 2008/7, 29-35.

KöSZEGHY Péter, Balassi Bálint (1554-1594), Pozsony, Kalligram, 2009 (Magyarok Emlékezete)

Kőszeghy Péter, Balassi Bálint: Magyar Amphión, Bp. Balassi, 2014.

Heinrich LAusBerg, Handbuch der literarischen Rhetorik, München, Max Hueber, 1960, III.

LUDÁNYI Mária, A „Supra aggnő” forrásvidéke” = Klaniczay-emlékkönyv: Tanulmányok Klaniczay Tibor emlékezetére, szerk. JANKOVICs József, Bp., Balassi, 1994, 136-142.

Madách-Rimay-kódexek, I, Rimay János hátrahagyott munkái, Quart. Hung. 3245/1.

Madách-Rimay-kódexek, II, Rimay János hátrahagyott munkái, Quart. Hung. 3245/2.

Madách-Rimay-kódexek, III, Sztregovai Madách Gáspár versei, Quart. Hung. 3246.

Magyar Erato, szerk. RÉz Pál, Bp., Magvető, 1987 (Magyar Hírmondó).

Magyar költészet Bocskaytól Rákócziig, s. a. r. EszE Tamás, KISs József, KLANICZAY Tibor, Bp., Szépirodalmi, 1953 (Magyar Klasszikusok).

Magyar müvelödéstörténeti lexikon: Középkor és kora újkor, VII, főszerk. KőSZEGHY Péter, szerk. TAMÁs Zsuzsanna, Bp., Balassi, 2007 
Magyar nyelvtörténeti szótár, szerk. SzARVAS Gábor, SIMONYI Zsigmond, I-III, Bp., 189 1893.

MÁTÉ Ágnes, „Most kiváltképpen két ifjú személyének szerencséjét éneklem”: Bevezetés az Eurialus és Lucretia latin filológiájába, doktori értekezés, Szeged, 2010.

Philipp MelanCHTHON, A retorika alapelemeinek két könyve $=$ Retorikák a reformáció korából, szerk. IMRE Mihály, Debrecen, Kossuth, 2000 (Csokonai Universitas Könyvtár: Források - Régi Kortársaink, 5), 49-86.

MiskolCZI Gáspár, Egy jeles vad-kert, s. a. r. STIRLING János, Bp., Magvető, 1983 (Magyar Hírmondó).

Ján MišIANIK, ECKHARDT Sándor, KLANICZAY Tibor, Balassi Bálint szép magyar komédiája: A Fanchali Jób-kódex magyar és szlovák versei, Bp., Akadémiai, 1959 (Irodalomtörténeti füzetek, 25).

NAGY Ferenc, Holtdudvar, szakdolgozat, Szeged, 2006.

NAGY Iván, Magyarország családai czímerekkel és nemzékrendi táblákkal, IX, Bp., Ráth Mór, 1862

NAGY Sándor, Adalékok XVI-XVII. századi elbeszélö költészetünk irodalmához, VI., EPhK, 1885. 172-182.

Nádor-kódex: 1508, kiad. PuSZTAI István, Bp., Magyar Nyelvtudományi Társaság, 1994 (Régi magyar kódexek 16).

O. NAGY Gábor, Magyar szólások és közmondások, Bp., Gondolat, 1976

ODORICS Ferenc, Interpretációs maximák, Irodalomtörténet, 1993, 541-549.

Publius Ovidius Naso, A szerelem müvészete, A szerelem orvosságai, ford. BEDE Anna, SZATHMÁRY Lajos, Európa/Helikon, 1982.

ÖTVÖs Péter, A Csáky-énekeskönyv, ItK, 1980, 486-509.

Pajkos énekek, szerk. SToll Béla, Bp., Szépirodalmi, 1984 (Magyar Ritkaságok).

PALÁSTHY Krisztina, Az LI. zsoltár világi és vallásos szöveghordozókban való megjelenése, kézirat, Pécs, 2015.

Janus PANnONiUs Munkái latinul és magyarul, szerk. V. KovÁcs Sándor, Bp., Tankönyvkiadó, 1972.

PAP Balázs, A sólyom szíve, Café Bábel, 51. sz., 49-53.

PAP Balázs, Az akrosztichonok és az első harminchárom, Ttáj, 2004/10, 44-52. 
PAP Balázs, Az Istenes énekek margóira = Ghesaurus: Tanulmányok Szentmártoni Szabó Géza hatvanadik születésnapjára, szerk. CsöRsz Rumen István, Bp., rec.iti, 2010, 335-342.

PAP Balázs, Históriák és énekek, Pécs, Pro Pannonia, 2014.

PÁvich Zsuzsanna, Az ószövetségi zene gyökerei, szakrális és világi kibontakozása, hatása az európai müvelödésre, PhD-értekezés, Bp., 2008.

PIRNÁT Antal, Rimay János: Az Úr engem sanyarita, = Klaniczay-emlékkönyv: Tanulmányok Klaniczay Tibor emlékezetére, szerk. JANKOVICs József, Bp. Balassi, 1994, 261-269.

PIRNÁT Antal, Balassi Bálint poétikája, Bp., Balassi, 1996 (Humanizmus és reformáció, 24).

RADVÁNSZKY Béla, Rimay János szerelmes versei, BpSzle, 1904, 371-382.

RADVÁNSZKY Béla, Sztregovai Madách Gáspár versei, ItK, 1901, 129-152.

Régi Magyar Költők Tára, I: Középkori költői maradványok, közzéteszi SzILÁDY Áron, Bp., 1877.

Régi Magyar Költök Tára, V: XVI. századbeli magyar költök müvei, 154?-1560, kiad. SzILÁDY Áron, Bp., 1886.

Régi Magyar Költök Tára, VI: XVI. századbeli magyar költök müvei, 1545-1559, kiad. SZILÁDY Áron, Bp., 1896.

Régi Magyar Költők Tára, VIII: XVI. századbeli magyar költők müvei, 1566-1577, kiad. DÉZSI Lajos, Bp., 1930.

Régi Magyar Költök Tára, XVII. század, 1, A tizenöt éves háború, Bocskay és Báthori Gábor korának költészete, szerk. KlANICZAY Tibor, STOLL Béla, s. a. r. BisZTRAY Gyula, KlanicZAY Tibor, Nagy Lajos, Stoll Béla, Bp., Akadémiai, 1959

Régi Magyar Költök Tára, XVII. század, 3, Szerelmi és lakodalmi versek, kiad. STOLL Béla, Bp., Akadémiai, 1961.

Régi Magyar Költök Tára, XVII. század, 8, Bethlen Gábor korának költészete, s. a. r. KomlovszKi Tibor, Stoll Béla, Bp., Akadémiai, 1976

Régi Magyar Költök Tára, XVII. század, 12, Madách Gáspár, Egy névtelen, Beniczky Péter, Gróf Balassa Bálint, Listius László, Esterházy Pál és Fráter István versei, szerk. STOLL Béla, s. a. rend. VARgA Imre, Cs. HAVAs Ágnes, Stoll Béla, Bp., Akadémiai, 1987.

Régi Magyarországi Nyomtatványok, 2, 1601-1635, szerk. BORSA Gedeon, HERVAY Ferenc, HoLl Béla, Bp., Akadémiai, 1983.

Régi Magyarországi Nyomtatványok, 4, 1656-1670, szerk. P. VÁsÁRHELYI Judit, Bp., Akadémiai, 2012.

RÉTHEI PRIKKEL Marián, A régi magyar énekmondók [II], EPhK, 1917, 201-208. 
RiMAY János Államiratai és levelezése, szerk. IPOLYI Arnold, Bp., 1887

RIMAY János Írásai, szerk. Ács Pál, Bp. Balassi, 1992 (Régi Magyar Könyvtár: Források, 1).

RiMAY János Munkái, kiad. RADVÁNSZKY Béla, Bp., 1904.

RimaY János Összes müvei, kiad. EcKHARDT Sándor, Bp. Akadémiai, 1955.

STOLL Béla, Szövegkritikai problémák a magyar irodalomban, Bp., Tankönyvkiadó, 1987

SZABÓ András, A Balassi-epicédium és Rákóczi Zsigmond, ItK, 1982, 645-649.

http://szelence.com/madach/index.html. (2016. 01.30.)

SZENCI MolNÁR Albert, Dictionarium Latinoungaricum, Nürnberg, 1604, a fakszimile szövegét közzéteszi Köszeghy Péter, Bp., Akadémiai, 1990 (Bibliotheca Hungarica Antiqua, XXV).

SZENTMÁRTONi SzABÓ Géza, Balassi Bálint halála = RiMAY János, Epicédium a Balassi fivérek, Bálint és Ferenc halálára, szerk. Ács Pál, Bp., 1994,

SzIGETI Csaba, A Senhal: a név neve, Palimpszeszt, 10. sz. http://magyarirodalom.elte.hu/palimpszeszt/10_szam/13.htm [2016. 01. 30.]

SzIGETI Csaba, Appendix Balassiana: Kronológia, tradíció, hagyománytudat a XVII. századi Balassi-követö nemesi költészetben, ItK, 1985, 675-687.

SZIGETI Csaba, Az magyar verseknek annya: Egy levél a Batthyány-udvarból 1630 körül, Vasi Szemle, 2013/4. 393-411.

SzIGETI Csaba, Közelitési kísérlet az obszcén antológiához, Prae, 2005/4, 24. sz., 51-54.

SzILASI László, A nyúl és a sólyom. Trópusok és funkcióik: Madách Gáspár Balassa János éneke sólymocskájárul címü versének példája, Literatura, 2000, 258-269.

SZILASI László, A sas és az apró madarak: Balassi Bálint költői nyelvének utóélete a XVII. század elsö harmadában, Bp., Balassi, 2008 (Humanizmus és Reformáció, 30).

SzILASI László, Hibbe(csúf): Rimay János Balassi-elogiuma = HÁRS Endre, Sz. L., Lassú olvasás, Szeged, Ictus-JATE, 1996 (deKON-könyvek, 7), 193-205.

SzILASI László, Nyakvers = Sz. L., Miért engedjük át az ácsnak a házépités örömét, Bp., József Attila Kör-Pesti Szalon, 1994 (JAK-füzetek, 72), 57-67

Szöveggyüjtemény a régi magyar irodalomból, szerk. KovÁCs Sándor Iván, II, Budapest, Osiris, 2003

TAKÁTS Sándor, A komáromi péntökösök = T. S., Müvelödéstörténeti tanulmányok a XVIXVII. századból, s. a. r. BENDA Kálmán, Bp., Gondolat, 1961 (Nemzeti Könyvtár), 286-295. 
TARNAI Andor, A parodia a XVI-XVIII. századi Magyarországon, ItK, 1990, 444-469.

Tóтн Tünde, $A$ virágének-vita = A magyar irodalom történetei, I, A kezdetektől 1800-ig, szerk. JANKOVITS László, ORLOVSZKY Géza, Bp., Gondolat, 2007, 133-146

Tóтн Tünde, Balassi és a neolatin szerelmi költészet, PhD-értekezés, Bp., 1999.

VADAI István, Balassi Bálint Fajtalan éneki, ItK, 1994, 673-681.

VADAI István, Batthyány Ferenc és Balassi Bálint = A Batthyányak évszázadai, szerk. NAGY Zoltán, Körmend-Szombathely, 2006, 217-222.

VADAI István, „,Forr gerjedt elmémre, mint hangyafészekre, sok új vers...”: Balassi Bálint saját kezü versfüzéréröl = V. I., Tükörben tükröződö tükör: Müértelmezések, Szeged, Tiszatáj, 2002.

VARGA Imre, Gróf Balassa Bálint magyar nyelvü önéletrajz-drámája 1643-ból, ItK, 1979, 359-370.

VARGA Imre, Tallózások Madách Gáspár körül, ItK, 1968, 67-74.

VARJAs Béla, Balassi Nagyciklusa, ItK, 1976, 585-612.

WALDAPFEL József, Balassi költeményeinek kronológiája, ItK, 1926, 185-210, 271-285.

WATHAY Ferenc Énekes könyve, szerk. KATONA Tamás, Bp., Magyar Helikon, 1976, I.

Winkler-kódex:1506, kiad. PuszTAI István, Bp., Akadémiai, 1988 (Codices Hungarici 9).

ZEMPLÉNYI Ferenc, Az európai udvari kultúra és a magyar irodalom, Bp., Universitas, 1998 (Historia Litteraria, 4).

ZEMPLÉNYI Ferenc, Müfajok reneszánsz és barokk között, Bp., Universitas, 2002 (Historia Litteraria, 11). 